\title{
Diabeteskennistoetsen in de beroepsopleiding tot huisarts
}

Citation for published version (APA):

Zuidweg, J. (1994). Diabeteskennistoetsen in de beroepsopleiding tot huisarts. [Doctoral Thesis, Maastricht University]. Rijksuniversiteit Limburg. https://doi.org/10.26481/dis.19940615jz

Document status and date:

Published: 01/01/1994

DOI:

10.26481/dis.19940615jz

Document Version:

Publisher's PDF, also known as Version of record

\section{Please check the document version of this publication:}

- A submitted manuscript is the version of the article upon submission and before peer-review. There can be important differences between the submitted version and the official published version of record.

People interested in the research are advised to contact the author for the final version of the publication, or visit the DOI to the publisher's website.

- The final author version and the galley proof are versions of the publication after peer review.

- The final published version features the final layout of the paper including the volume, issue and page numbers.

Link to publication

\footnotetext{
General rights rights.

- You may freely distribute the URL identifying the publication in the public portal. please follow below link for the End User Agreement:

www.umlib.nl/taverne-license

Take down policy

If you believe that this document breaches copyright please contact us at:

repository@maastrichtuniversity.nl

providing details and we will investigate your claim.
}

Copyright and moral rights for the publications made accessible in the public portal are retained by the authors and/or other copyright owners and it is a condition of accessing publications that users recognise and abide by the legal requirements associated with these

- Users may download and print one copy of any publication from the public portal for the purpose of private study or research.

- You may not further distribute the material or use it for any profit-making activity or commercial gain

If the publication is distributed under the terms of Article $25 \mathrm{fa}$ of the Dutch Copyright Act, indicated by the "Taverne" license above, 
DLABETESKENNISTOETSEN IN DE BEROEPSOPLEIDING TOT HUISARTS 


\title{
Diabeteskennistoetsen in de beroepsopleiding tot huisarts
}

\author{
Proefschrift \\ ter verkrijging \\ van de graad van doctor aan de \\ Rijksuniversiteit Limburg te Maastricht, op gezag van \\ de Rector Magnificus, Prof. Dr. H. Philipsen, \\ volgens het besluit van het College van Dekanen, \\ in het openbaar te verdledigen op \\ woensdag, 15 juni 1994 om 16.00 uur
}

door

Jacobus Zuidweg

geboren te Oss in 1956 


$$
\begin{aligned}
\text { Promotores : Prof. Dr. W.H.F.W. Wijnen } \\
\text { : Prof. Dr. J.D. Mulder } \\
\text { Co-promotor : Dr. L.H.C. Tan }
\end{aligned}
$$

Beoordelingscommissie: Prof. Dr. H.F.J.M. Crebolder, voorzitter Prof. Dr. R.P.T.M. Grol

Prof. Dr. A.C. Nieuwenhuijzen Kruseman Prof. Dr. E. van Veen

Dr. C.P.M. van der Vleuten

Dit onderzoek en de rapportage ervan is mogelijk gemaakt met steun van:

Stichting Diabetes Researchfonds Nederland

De Stichting Diadata te Maastricht

Novo Nordisk Farma

Het Nederlands Huisartsen Genootschap

De firma E. Merck, Nederland BV te Amsterdam 
Wanneer de Noordzee koppig breekt aan de hoge duinen

en witte vlokken schuim uiteen slaan op de kruinen

Wanneer de norse vloed beukt aan een zwart basalt

en over dijken, duinen de grijze nevel valt.

Wanneer bij eb het strand voos is als een woestijn

En natte Westenwinden gieren van venijn,

Dan vecht mijn land, mijn vlakke land.

Wanneer de regen daalt op straten, pleinen, perken, op dak en torenspits

Wanneer men over kerken die in dit vlakke land de enige bergen zijn

Wanneer onder de wolken mensen dwergen zijn

Wanneer de dagen gaan in domme regelmaat

En een barre Oostenwind het land nog vlakker slaat

Dan wacht mijn land, mijn vlakke land

Wanneer de lage lucht vlak over het water scheert,

Wanneer de lage lucht ons nederigheid leert,

Wanneer de lage lucht grijs als leisteen is

Wanneer de lage lucht een vaandels keilen is

Wanneer de Noordenwind de vlakte vierendeelt

Wanneer de Noordenwind door onze havens speelt

Dan kraakt mijn land, mijn vlakke land

Wanneer de Schelde blinkt in de zuidelijke zon

En elke Vlaamse vrouw flaneert in zonjapon

Wanneer de eerste spin zijn lentewebben weeft

Of dampende het veld in julizonlicht beeft

Wanneer de Zuidenwind schatert door het graan

Wanneer de Zuidenwind jubelt langs de baan

Dan juicht mijn land, mijn vlakke land 


\section{Inhoudsopgave}

Voorwoord

pag. 9

Hoofdştuk 1 Inleiding

pag. 11

Hoofdstuk 2 Vraagstelling en methode

pag. 17

Hoofdstuk 3 Diagnostiek, behandeling en controle van Niet InsulineAfhankelijke Diabetes Mellitus in de huisartspraktijk en het Kernispakket

pag. 23

Hoofdstuk 4 Toetsconstructie, validiteit en toetsvorm

pag. 33

Hoofdstuk 5 Afname toets 1 bij huisartsen-in-opleiding

pag. 49

Hoofdstuk 6 Afname toets 2 bij huisartsen-in-opleiding

pag. 57

Hoofdstuk 7 Afname toets 1 bij ervaren huisartsen

pag. 63

Hoofdstuk 8 Vergelijkbaarheid: toets 3

pag. 69

Hoofdstuk 9 Groei in kennis met betrekking tot diabetesbehandeling gedurende de eenjarige huisartsopleiding

pag. 75

Hoofdstuk 10 Conclusies

pag. 85

Samenvatting

pag. 91

Summary

pag. 93

\section{Bijlagen:}

1. Landelijke toets diabetes in de huisartspraktijk / Toets I

pag. 95

2. Landelijke toets diabetes in de huisartspraktijk / Toets 2

pag. 115

3. Kennispakket voor de behandeling van diabetes in de huisartspraktijk

pag. 135

4. Vragenlijst instituutsgebonden onderwijs diabetes.

pag. 167

5. Aanvullende vragenlijsten deelnemers toets 1 en toets 2 en praktizerende huisartsen

pag. 171

6 Resultaten eerste afname bij huisartsen in opleiding, uitsplitsingen

pag. 177

7. Resultaten tweede afname bij huisartsen in opleiding, uitsplitsingen

pag. 179

8. Toename in kennis gedurende de huisartsopleiding per instituut, uitsplitsingen

pag. 181

Dankwoord

pag. 185

Curriculum vitae 


\section{Voorwoord}

Dit proefschrift is voortgekomen, uit een onderzoeksproject dat in de periode van 1984 tot en met 1986 heeft plaatsgevonden aan de Universiteit van Amsterdam. Het project had tot doel om landelijk bruikbare evaluatietechnieken te ontwikkelen om kennis en vaardigheid van huisartsen in opleiding te toetsen ten aan zien, van diagnose, behandeling, begeleiding en preventie van diabetes mellitus.

$\mathrm{Na}$ de start onder de ambitieuze naam "Kennis en vaardigheid met betrekking tot patiênten met diabetes mellitus in de beroepsopleiding tot huisarts", bleek al spoedig dat de vraagstelling, gezien de beschikbare menskracht en middelen, diende te worden beperkt. Besloten werd hel vaardigheidsdeel te laten vervallen. Het project was met een looptijd van twee en een hall jaar en de menskracht van 0,4 fte onderzoeker, 0,1 fte coőrdinator, 0,2 fte adiministracieve ondersteuning en ad hoc ondersteuning bij de verwerking en analyses van de toetsgegevens, niet opgezet als promotie onderzoek. Doordat het onderzoek landelijk plaatsvond en er geen infrastructuur voorhanden was voor een toets afname op alle acht huisartsinstituten, ging veel tijd zitten in het coördineren van de afname van de toetsen. De analyses van de gegevens hebben zich beperkt tot de - binnen het project- practisch noodzakelijke. Enkele voor een proefschrift voor de handliggende nadere analyses van het verkregen onderzoeksmateriaal zijn. noodgedwongen niet uitgevoerd. Dit verklaart het bescheiden karakter van de rapportage.

Met de steun van velen is het echter gelukt dit project, ondanks de bovengenoemde beperikende omstandigheden, in de vorm vars een proefschrift af $t e$ ronden. Her project heelt een vcortrekkersrol kunnen vervullen bij het opzetten van landelijke evaluatieprojecten in de. huisansopleiding. 
ant

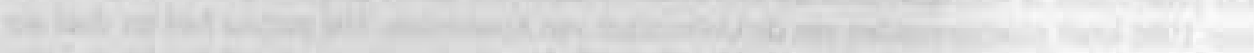

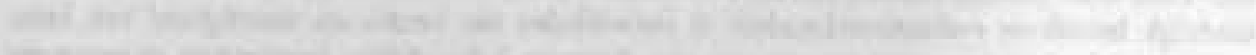
-

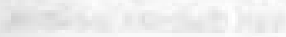

and

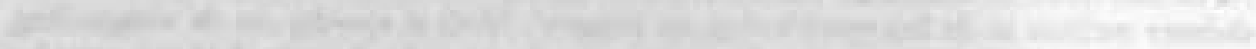
(1)

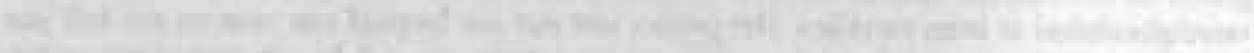
and

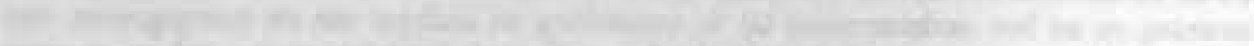

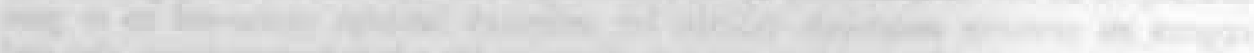
-

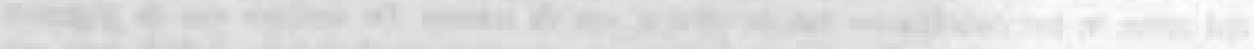

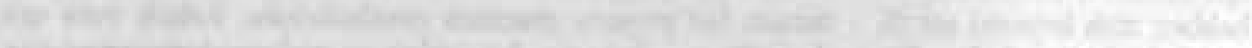
and

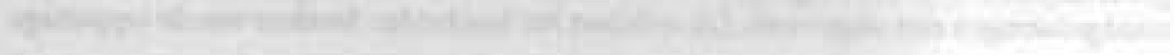

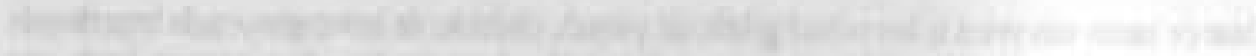

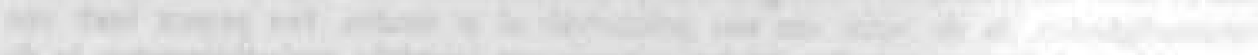
and 


\section{Hoofdstuk 1}

\section{Inleiding}

In dit proefschrift komen twee nogal van elkaar verschillende disciplines aan de orde. Enerzijds wordt een deelgebied uit de medische discipline - de diagnostiek en behandeling van patiènten met diabetes mellitus - besproken, anderzijds wordt gebruik gemaakt van methoden en technieken uit de sociale wetenschappen, meer specifiek de onderwijskunde, voor zover het de constructie van meetinstrumenten en het verwerken van de resultaten betreft. Het benutten van twee verschillende disciplines binnen één kader kan gemakkelijk leiden toı het risico, dat sommige passages als te beknopt en andere als te uitvoerig zullen worden beschouwd, afhankelijk van de achtergrond van de lezer. De passages op het eigen vakgebied zullen wellicht als te omslachtig worden gezien, terwijl de passages op het gebied van de andere discipline misschien iets uitvoeriger zouden kunnen zijn. Dit risico is amper te vermijden, wanneer men zowel medici als onderwijskundigen wil aanspreken. Het onderzoek, dat in dit proefschrift wordt gepresenteerd, heeft betrekking op de beroepsopleiding tot huisarts en dat is een werkterrein dat medici en onderwijskundigen/sociale wetenschappers met elkaar delen.

De geschiedenis van de beroepsopleiding tot huisarts kan in grote lijnen als volgt worden geschetst. Het Academisch Statuut van 1968 regelde de zesjarige opleiding tot assistent-arts met een daarop volgend zevende jaar naar keuze. Aan het Utrechtse universitaire huisartsinstituu werd in 1971 gestart met de eerste huisartsopleiding als invulling van het zevende jaar van de opleiding tot arts. Nadat in 1974 een aanpassing van het Academisch Statuut de artsopleiding wijzigde in een zesjarige opleiding tot basisarts, kreeg de huisartsopleiding een postacademisch karakter.

$\mathrm{Na}$ de voltooiing van de medische studie door het behalen van het basisartsexamen is het mogelijk voor een deel van de afgestudeerden de beroepsopleiding tot huisarts te volgen. Dit opleidingsprogramma wordt georganiseerd door het aan elke medische faculteit verbonden universitaire huisartsinstituut. In de periode 1971-1976 is de Nederlandse beroepsopleiding tot huisarts officieel van start gegaan bij de zeven universitaire instituten voor huisartsgeneeskunde aan de gevestigde medische faculteiten. Bovendien startte binnen diezelfde periode - in 1974 tegelijkertijd inet het feitelijke begin van de achtste medische faculteit, een achtste opleiding aan het universitaire instituut voor huisartsgeneeskunde in Maastricht.

De verantwoordelijkheid voor de regelgeving voor deze beroepsopleiding is in handen van de beroepsgroep, met name van het. College voor Huisartsgeneeskunde (CHG), inmiddels uitgebreid tot College voor Huisartsgeneeskunde en Verpieeghuisgeneeskunde (CHVG), en de Huisarts Registratie Commissie (HRC), die inmiddels ook haar terrein uitgebreidl heeft toll de verpleeghuisgeneeskunde en derhalve nu Huisarts en Verpleeghuisars Registratie Commissie (HVRC) heet.

Bij de invulling van de éénjarige opleidingsprogramma's hadden de huisartseninstituten een grote vrijheid. Het feitelijke gevolg hiervan was een grote diversiteit in opleidingsprogramma's. Het College voor Huisartsgeneeskunde ( $\mathrm{CHG}$ ) stelde uitsluitend regels met betrekking tot een aantal randvoorwaarden. Hierbij moet worden gedacht aan globale aanwijzingen, onder meer omtrent:

- de inrichting van de opleidingspraktijken

- aanwezigheid van een spreekkamer,

- een aparte onderzoekskamer en een wachtkamer,

- voldoende en aan de tijd aangepast instrumentarium,

- aanwezigheid van een goed bijgehouden medische registratie van patiéntgegevens,

- de praktijkvoering en opleidingsbereidheid van de huisartsopleiders 
- minstens vijf jaar gepraktizeerd hebben,

- zorgvuldige praktijkvoering,

- bereid zijn om dagelijks patiêntenbesprekingen met de huisarts-in-opleiding te houden,

- bereid zijn om samen te werken met het huisarisinstituut,

- de rol van de universitaire instituten voor huisartsgeneeskunde

- jaarlijks een globaal opleidingsprogramma voorleggen aan het CHG en de HRC,

- organiseren van de terugkomdagen,

- beschikken over voor het onderwijs noodzakelijke personeel, onderwijsruimten en een

bibliotheek,

- regelmatige kontakten met de opleiders onderhouden.

Was aan genoemde voorwaarden voldaan dan kon - na afronding van de opleiding - inschrijving in het register van erkende huisartsen plaatsvinden (1).

In 1983 werd een aantal van bovengenoemde vereisten meer gedetailleerd omschreven. Zo werd onder andere besloten dat het verblijf in de opleidingspraktijk minimaal acht maanden diende te duren. De huisartseninstituten werden verplicht om minimaal vier groepen assistenten per jaar op te leiden teneinde voldoende ervaring op te doen. Daamaast werd een Bemiddelingscommissie ingesteld met als taak op te treden bij geschillen in de opleidingssituatie. In een toelichting werd gesteld dat eisen met betrekking tot inhoud en evaluatie pas in een later stadium - namelijk bij de invulling van een tweejarige opleiding - zouden worden omschreven (2). Er bestond - en bestaat tot op heden - geen formeel afsluitend examen.

Door een aantal huisartseninstituten werden pogingen ondernomen om zicht te krijgen op het onderwijs en op het product ervan: de huisarts-in-opleiding (haio). De problemen die zich daarbij voordeden werden in 1982 door Van Leeuwen (3) geschetst. Zij meldde een groot gebrek aan instrumenten voor het meten van medische competentie van huisartsen-in-opleiding. Voor zover ze er waren, voldeden ze niet aan elementaire eisen van betrouwbaarheid, validiteit en praktische bruikbaarheid. Opvallend was dat er tussen de instituten nauwelijks sprake was van onderlinge af temming en samenwerking op het gebied van evaluatie. Mede als gevolg van de toenemende vraag vanuit de maatschappij naar een betere herkenbaarheid van de af te leveren huisarts en het steeds duidelijker profileren van de inhoud van de taken van de huisarts, groeide de behoefte aan samenwerking tussen de instituten.

In 1982 werd door het Interfacultair Overleg Huisartsgeneeskunde (1OH), waarin de acht huisartsinstituten landelijk nauw samenwerken, de Werkgroep Evaluatie geinstalleerd. In deze Werkgroep had elk instituut een vertegenwoordiger, die zich met evaluatie bezighield. De Werkgroep had vooral tot doel te komen tot coordinatie van de diverse activiteiten op het gebied van evaluatie. Gestart werd met een inventarisatie van de evaluatiemethoden die door de instituten werden gebruikt. Over deze inventarisatie werd in 1983 (4) en 1986 (5) gerapporteerd. Het voor de hand liggende streven om op eenvoudige wijze de medische competentie van de aanstaande huisarts in al haar dimensies te meten bleek echter niet realiseerbaar.

In 1983 verschenen twee belangrijke documenten met gedetailleerde omschrijvingen van de huisartsgeneeskunde in Nederland. Vanuit de beroepsgroep werd door de Landelijke Huisartsen Vereniging (LHV) het "Basistakenpakket van de huisarts" (6) gepubliceerd. In dit basistakenpakket wordt een uitgebreide omschrijving van het werkveld van de huisarts gegeven. Hoofdonderdelen hiervan zijn :

A: Functieomschrijving

B: Taken, afgeleid van het hulpverleningsproces

C: Taken, afgeleid van bepaalde categorieên patiènten

D: Ondersteunende taken

E: Preventieve taken

F: Overige taken 
Zorg voor de chronische patiènt maakt deel uit van onderdeel C. Hierbij wordt expliciet de zorg voor patiênten met type II diabetes mellitus genoemd.

"Het is de taak van de huisarts type II diabetes zelfstandig te diagnostiseren en te behandelen" (6).

Als tweede document verscheen vanuit het onderwijs in de huisartsgeneeskunde het rapport "Kenmerken van de Huisarts II " (7). In dit rapport is een nauwkeurige beschrijving van de inhoudelijke opleidingseisen voor aanstaande huisartsen te vinden. De auteurs rekenen type II diabetes mellitus tot de aandoeningen, die de huisarts in eigen beheer zou moeten behandelen en begeleiden, dit in tegenstelling tot type $\mathbf{I}$ diabetes mellitus, waarbij de huisarts alleen een diagnostiserende taak krijgt toebedeeld.

In 1984 besloot de Werkgroep Evaluatie een begin te maken met het ontwikkelen van toetsen die toegepast zouden kunnen worden door de acht opleidingsinstituten voor Huisartsgeneeskunde. In het kader hiervan werd een project geèntameerd met de titel "Kennis en vaardigheid met betrekking tot patiênten met diabetes mellitus bij aanstaande huisartsen" (8). Uit dit project is dit proefschrift voortgekomen. De keuze voor diabetes als object van onderzoek werd ingegeven door de breedte van het onderwerp. Dit maakt het mogelijk om een heel scala aan aspecten van de (huisarts-)geneeskunde aan de orde ie stellen. De Werkgroep Evaluatie, waaruit de leden van de begeleidingsgroep van het project voortkwamen, heeft van 1984 tot en met 1986 mede gefungeerd als klankbordgroep voor de begeleidingsgroep en met name ook voor de auteur.

De beide in dit project ontwikkelde toetsen - de "Landelijke toets diabetes in de huisartspraktijk, toets 1 en 2 " (9,10) - die integraal als bijlage 1 en 2 zijn opgenomen, hebben een voortrekkersrol vervuld voor latere toetsactiviteiten in de beroepsopleiding tot huisarts.

Begin 1988 werd de beroepsopleiding tot huisarts verlengd tot twee jaar, in afwachting van een beslissing over de definitieve duur van drie jaar. Vanuit de Commissie Curriculumconstructie Beroepsopleiding tot Huisarts (CCBOH) en het College voor Huisartsgeneeskunde (CHG, thans CHVG: College voor Huisarts- en Verpleeghuis Geneeskunde) werd gesteld dat alleen een driejarige curriculumduur voor voldoende niveau garant zou kunnen staan (11). Inmiddels is in september 1991 het besluit genomen om de beroepsopleiding tot huisarts vanaf 1993 tot drie jaar te verlengen.

In 1987 besloot het IOH op advies van de Commissie Curriculumconstructie Beroepsopleiding tot Huisarts om het Samenwerkingsverband Interfacultair Overleg Huisartsgeneeskunde op te richten. Dit Samenwerkingsverband kreeg professionele ondersteuning in de vorm van een Witvoerend Bureau. Het kreeg o.a. als taak een landelijk toepasbaar toetsings- en evaluatiesysteem op te zetten voor de beroepsopleiding tot huisarts en de hiervoor benodigde instrumenten te ontwikkelen. Het Samenwerkingsverband verzorgt nu de productie en afname van landelijke, experimentele kennistoetsen die driemaal per jaar worden afgenomen bij alle huisartsen-in-opleiding. Regelmatig worden hierin ook enkele vragen van de diabetestoetsen opgenomen. Ook de vorm van de diabetestoets, namelijk een korte casusbeschrijving gevolgd door enkele vragen in de vorm van beweringen met als antwoordmogelijkheid "juist", "vraagteken" of "onjuist" is overgenomen in de landelijke kennistoetsen van het Samenwerkingsverband.

Als onderdeel van het in dit proefschrift beschreven onderzoek werd het "Kennispakket voor de behandeling van diabetes mellitus in de huisartspraktijk" (12) ontwikkeld (zie bijlage 3). Dit vormt de inhoudelijke onderbouwing van de diabetestoetsen. Het kennispakket is samengesteld met hulp van deskundigen uit verschillende disciplines - te weten enkele huisartsen en internisten, ern neuroloog, een oogarts, een gynaecoloog, een dietist, een medisch socioloog en een diabetesverpleegkundige en werd vervolgens op validiteit en volledigheid beoordeeld door 
een panel van ter zake kundige huisartsen. Deze procedure wordt in Hoofdstuk 4 paragraaf 4 uitgebreid besproken.

Sinds 1987 is het Nederlands Huisartsengenootschap (NHG), de wetenschappelijke vereniging van de beroepsgroep, waarbij thans ruim $60 \%$ van de praktizerende huisartsen is aangesloten, actief bezig met het formuleren van standaarden. Dit zijn handelingsprotocollen over onderwerpen uit de huisarisgeneeskunde. Er wordt een vaste procedure gevolgd voor het opstellen van deze standaarden. De eerste stap in deze procedure is het bereiken van consensus omtrent de inhoud van de desbetreffende standaard in een kleine groep van ter zake kundige huisartsen, die zich hiervoor hebben aangemeld, dan wel gevraagd zijn om hierin zitting te nemen. Vervolgens wordt de conceptversie uitgetest in de praktijk van een twintigtal huisartsen. Hierna volgt autorisatie door een groep gezaghebbende huisartsen, deels hoogleraren, deels niet facultair werkzame, ervaren practici. Daarna volgt publicatie in het tijdschrift Huisarts en Wetenschap, het forum van de Nederlandse huisartsgeneeskunde.

Het NHG presenteert bij de standaarden ook steeds een nascholingsadvies in de vorm van een zogenaamd "deskundigheidsbevorderingspakket". Dergelijke deskundigheidsbevorderingspakketten vormen een leidraad bij het organiseren van nascholing voor groepen huisartsen.

De eerste NHG-standaard had de behandeling van type II diabetes mellitus als onderwerp en verscheen in 1989 (13). Het "Kennispakket voor de behandeling van diabetes mellitus in de huisartspraktijk" en de beide diabetestoetsen maken deel uit van het deskundigheidsbevorderingsyakket bij de eerste NHG-standaard (14). Behalve over diabetes zijn er momenteel een tiental pakketten, onder andere over enkeldistorsie, over oogheelkundig onderzoek en over perifeer arterieel vaatlijden.

Inmiddels fungeren de verschillende NHG-standaarden mede als uitgangspunt voor de productie van toetsmateriaal door het Samenwerkingsverband-IOH voor de landelijke kennisloetsing van huisartsen-in-opleiding.

In dit proefschrift wordt gerapporteerd over de constructie en afname van beide diabetestoetsen bij huisartsen-in-opleiding. De afname heeft betrekking op medici die in 1985 en 1986 de eénjarige beroepsopleiding tot huisarts volgden aan één van de acht huisartseninstituten. Alle acht instituten namen deel aan dit onderzoek.

In hoofdstuk 2 worden de onderzoeksvraagstellingen en de onderzoeksmethoden nader uilgewerkt.

Hoofdstuk 3 beschrijft de totstandkoming van het "Kennispakket voor de behandeling van diabetes mellitus in de huisartspraktijk".

Hoofdstuk 4 gaat nader in op de toetsconstructie en op de belangrijkste aspecten van validiteit en betrouwbaarheid.

Hoofdstuk 5 doet verslag van de afname van toets 1 bij 219 huisartsen-in-opleiding. Deze afname vond plaats aan het begin van hun opleidingsjaar:

Hoofdstuk 6 geeft de resultaten van de afname van toets 2 bij 191 huisartsen-in-opleiding. Deze afname vond plaats aan het einde van hun opleidingsjaar.

In hoofdstuk 7 wordt de afname van toets 1 bij 62 ervaren huisartsen beschreven.

In hoofdstuk 8 wordt de problematiek besproken van het vergelijken van de uitslagen van twee niet identieke toetsen. De vergelijkbaarheid van de in dit onderzoek gebruikte toetsen wordt vervolgens onderzocht.

Hoofdstuk 9 beschrijft de groei in kennis tijdens de beroepsopleiding, zoals die in dit onderzoek kon worden vastgesteld.

In hoofdstuk 10 tenslotte worden enkele conclusies getrokken met betrekking tot de uitkomsten van dit onderzoek.

\section{Literatuur bij hoofdstuk 1}

1. College voor Huisartsgeneeskunde. Opleidingseisen huisartsgeneeskunde. Medisch Contact 1974; 29: 1154-9. 
2. Van Geldorp GM (red), Alting von Geusau WAM, Van Amerongen HL et al. Opleiden en leren in de huisartspraktijk. Utrecht: Bunge, 1985.

3. Van Leeuwen YD. Toetsstenen en struikelblokken: een kritische beschouwing van de evaluatie van de beroepsopleiding tot huisarts. Maastricht: Vakgroep Huisartsgeneeskunde Rijksuniversiteit Limburg, 1982.

4. Inventarisatie van evaluatie instrumenten in de beroepsopleidingen. Utrecht: Werkgroep Evaluatie $10 \mathrm{H}, 1983$.

5. Inventarisatie van evaluatie instrumenten in de beroepsopleidingen. Utrecht: Werkgroep Evaluatie $\mathrm{IOH}, 1986$.

6. Springer MP (red). Basistakenpakket van de huisarts. Utrecht: Landelijke Huisartsen Vereniging, 1983.

7. Van Es JC, De Melker RA, Goosmann FCL. Kenmerken van de huisarts II. Utrecht: Bohn, Scheltema \& Holkema, 1983.

8. Zuidweg J, Tan LHC. Kennis en vaardigheid met betrekking tot patiènten met diabetes mellitus bij aanstaande huisartsen. Eindrapport. Amsterdam: Instituut voor Huisartsgeneeskunde, Universiteit van Amsterdam, 1987.

9. Zuidweg J, Van Leeuwen YD, Tan LHC, Van Geldorp G. Landelijke toets diabetes, in de huisartspraktijk voor artsen in opleiding tot huisarts en huisartsen. Toets 1. Maastricht: Stichting Diadata, 1988.

10. Zuidweg J, Van Leeuwen YD, Tan LHC, Van Geldorp G. Landelijke toets diabetes in de huisartspraktijk voor artsen in opleiding tot huisarts en huisartsen. Toets 2. Maastricht: Stichting Diadata, 1988.

11. Pollemans MC, Tan LHC. Toetsing van kwaliteit, landelijke evaluatie van de interimberoepsopleiding tot huisarts. Rapport SV-IOH-15. Utrecht: Samenwerkingsverband-1OH, 1990.

12. Zuidweg J, Van Leeuwen YD, Van Geldorp G, Tan LHC. Kennispakket voor de behandeling van diabetes mellitus in de huisartspraktijk. NHG Publicaties deskundigheidsbevordering nr.1. Utrecht: Nederlands Huisartsen Genootschap, 1990.

13. Rutten GEHM, Cromme PVM, Zuidweg J, Mulder JD. Huisarts en diabetes type II. Huisarts en Wetenschap 1989; 32: 124-9.

14. Pakket voor deskundigheidsbevordering. 1. Diabetes mellitus type II. Utrecht: Stichting Deskundigheidsbevordering Huisartsen en Nederlands Huisartsen Genootschap, 1990. 
Whata

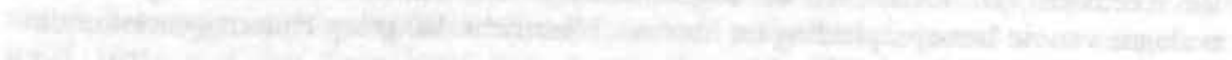

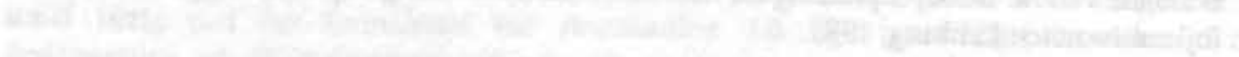

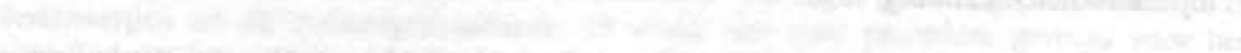

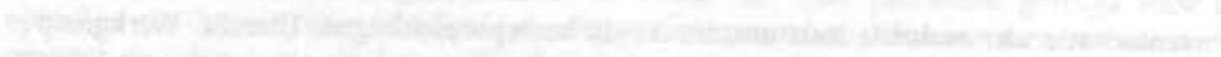

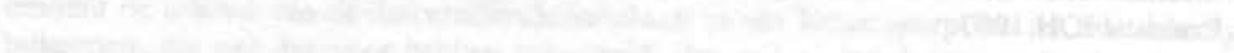

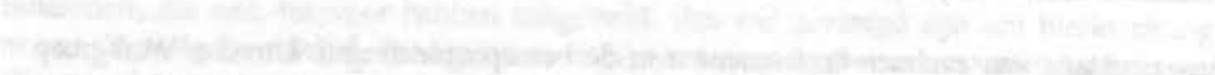

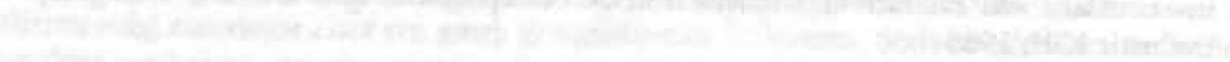
Than

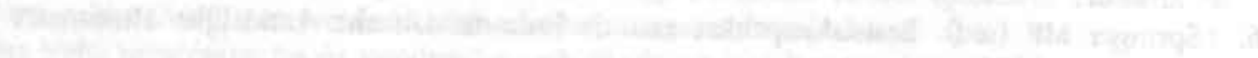

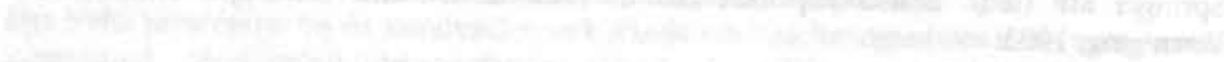

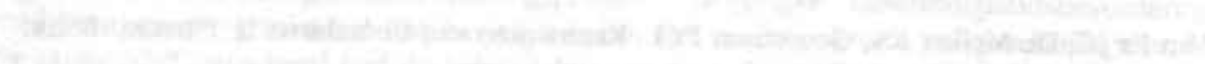

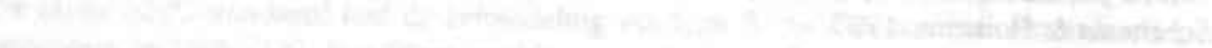

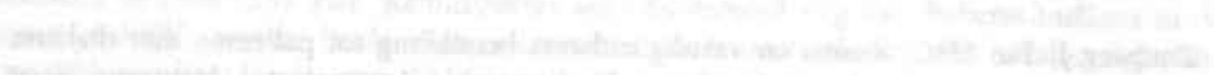

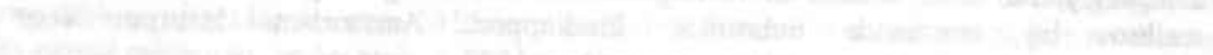

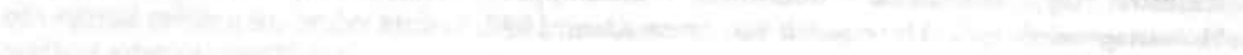

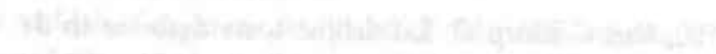

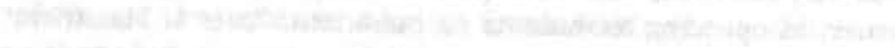

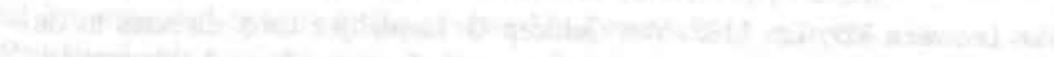

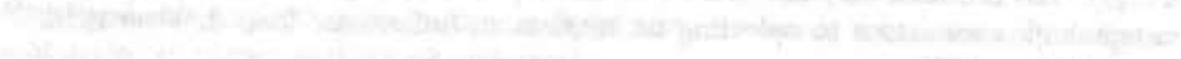

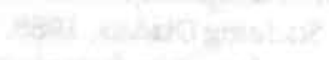

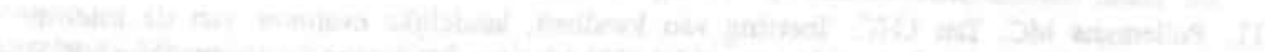

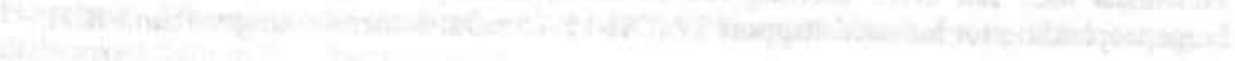




\section{Hoofdstuk 2}

\section{Vraagstelling en methode}

\subsection{De vraagstellingen}

De algemene vraagstelling van dit onderzoek kan worden getypeend als een evaluatievraag. Bij een evaluatievraag probeert de onderzoeker de waarde vast te stellen van een nader aan te duiden object. In dit geval gaat het over de evaluatie van een opleidingsprogramma. Bij de evaluatie van opleidingsprogramma's kan men in principe twee verschillende wegen bewandelen. Men kan aan betrokken groeperingen vragen welke waarde men aan een opleidingsprogramma toekent (programma-evaluatie). Men kan ook de nadruk leggen op de resultaten die in het kader van een opleiding worden bereikt (evaluatie van studieresultaten). In dit onderzoek werd gekozen voor de laatste werkwijze. Nagegaan zal worden of het profije, dat cursisten van een (onderdeel van een) opleidingsprogramma hebben op een verantwoorde wijze kan worden beschreven. Wanneer effecten van opleidingsprogrammals op een verantwoorde wijze kunnen worden gemeten, kunnen eventuele verschillen tussen de resultaten van verschillende opleidingsprogramma's beter in kaart worden gebracht. Het wordt dan ook mogelijk te werken aan de uniformering van de eindresultaten van opleidingsprogramma's, indien men dat wenselijk of noodzakelijk vindt. Op basis van gemeten opleidingsresultaten kunnen daarenboven kwaliteitsgaranties worden gegeven aan een samenleving, die aangewezen is op de diensten van degenen die worden opgeleid.

De algemene vraagstelling zal in het kader van dit onderzoek verder worden toegespitst op een specifiek opleidingsprogramma. Inhoudelijk zal de opleiding tot huisarts in dit onderzoek centraal staan. De betrokkenheid van de auteur bij de beroepsgroep van huisartsen heef feitelijk tot deze keuze geleid. De algemene vraagstelling kan dan ook als volgt worden gespecificeerd: In hoeverre is het mogelijk resultaten van de beroepsopleiding tot huisarts op een verantwoorde manier in kaart te brengen?

Tijdens de uitvoering van het hier gerapporteerde onderzoek was er, zoals gezegd, een énjarige beroepsopleiding tot huisarts. Binnen deze beroepsopleiding zijn globaal gezien twee gedeelten te onderscheiden: een relatief klein cursorisch gedeelte en een veel groter gedeelte, dat als stage kan worden getypeerd. Het cursorische gedeelte van de eénjarige beroepsopleiding tot huisarts is vooral theoretisch van aard en maakt deel uit van het programma van de zogeheten terugkomdag. Het grootste gedeelte van de opleidingsperiode wordt door de huisartsen-inopleiding doorgebracht in stagepraktijken. Deze stagepraktijken liggen veelal gespreid in een relatief grote regio. Gedurende eén dag per week verlaten alle leden van een opleidingsgroep de stagepraktijk om gezamenlijk "terug te komen" naar het huisartsinstituut. Slechts een gedeelte van deze terugkomdag wordt besteed aan kennisoverdrach. Behalve dit meer theoretische gedeelte krijgen het uitwisselen van ervaringen en het leren hanteren van de arts-patiènt relatie eveneens aandacht op deze terugkomdag. Beide laatstgenoemde opleidingselementen, te weten het uitwisselen van ervaringen opgedaan in de stagepraktijk en het hanteren van de arts-patient relatie, hebben in de opleidingsfilosofie van de Nederlandse huisartseninstituten van meet af aan een zwaar accent gekregen, aangezien de huisartsgeneeskunde nu juist op deze punten aanzienlijk verschilt van de klinische geneeskunde. Immers veel meer dan in de klinische geneeskunde, waarin het accent vooral ligt. op het op hoog niveau uitoefenen van een vrij beperkt en meestal somatisch deel van de geneeskunde, ziet de huisartsgeneeskunde een belangrijke taak in het verlenen van psycho-sociale begeleiding, continuiteit van zorg en - ook niet strikt medisch-somatische - begeleiding aan patiênten met chronische aandoeningen. Dit 
vraagt andere vaardigheden zoals reflectie op het handelen als arts en vaardigheden op het terrein van de consultvoering.

De eerste vraagstelling voor dit onderzoek luidt derhalve als volgt:

\section{Is het mogelijk om effecten van een opleidingsprogramma tot huisarts op een verantwoorde wijze te beschrijven?}

In zijn algemeenheid is de beschreven vraagstelling te ambitieus, omdat het aantal relevante onderwerpen in het kader van een huisartsenopleiding te groot en te rijk geschakeerd is om in het kader van een dissertatie uitputtend aan de orde te kunnen stellen. De beschikbare menskracht en de beschikbare middelen maakten het noodzakelijk om met betrekking tot de meer algemene vraagstelling exemplarisch te werk te gaan. Bij een exemplarische benadering wordt verondersteld, dat de bevindingen die worden gedaan bij het ene onderwerp in principe ook bij andere onderwerpen kunnen worden gevonden.

De in dit proefschrift beproefde methode bij het onderzoeken van het deelgebied diabetes mag worden verondersteld ook bruikbaar te zijn voor een soortgelijke exercitie op het terrein van andere veel voorkomende chronische aandoeningen in de huisartspraktijk, zoals Chronische Aspecifieke Respiratoire Aandoeningen (CARA), Chronic Obstructive Pulmonary Disease (COPD) of ook wel chronische bronchitis/ emfyseem genoemd, degeneratieve gewrichtsaandoeningen, zoals arthrose, chronisch coronaria lijden en aandoeningen van de perifere arteriele circulatie (chronische hart- en vaatziekten) en hypertensie.

Voor een onderzoek, dat in principe zou moeten functioneren als een pilotstudie voor het evalueren van een beroepsopleiding op nationale schaal, is een dergelijke veronderstelling verdedigbaar, wanneer het gekozen. onderwerp niet te zeer als "buitenbeentje " moet worden getypeerd.

De aandoening diabetes mellitus lijkt geschikt om als onderwerp te kiezen voor een exemplarische benadering van de algemene vraagstelling omdat:

- de prevalentie van diabetes mellitus zo hoog is - volgens conservatieve schattingen lijdt $2 \%$ van de populatie aan deze aandoening (1 ) - dat elke huisarts daarmee in zijn of haar huisartspraktijk geregeld wordt geconfronteerd.

Uit het Scenariorapport (1) kan tevens worden afgeleid dat door de demografische ontwikkeling van de Nederlandse bevolking (vergrijzing en de te verwachten toename van het aantal hoogbejaarden, de zogenaamde dubbele vergrijzing), de prevalentie in de komende 15 jaar aanzienlijk zal stijgen.

- in de huisartspraktijk een belangrijke plaats wordt ingeruimd voor het behandelen en begeleiden van patiênten met veel voorkomende chronische aandoeningen, zoals afgeleid kan worden uit de plaats en omvang van het onderdeel hierover in het Basistakenpakket van de huisarts (2).

- diabetes mellitus een veelheid aan problemen met zich mee kan brengen, zowel in de lichamelijke als in de psychosociale sfeer. Op het lichamelijke vlak kan hierbij worden gedacht aan aandoeningen van hart en bloedvaten, aantasting van het perifere zenuwstelsel, oogaandoeningen en nieraandoeningen. Dit maakt een weloverwogen beleid op het gebied van de secundaire preventie noodzakelijk (3). Op het psychosociale vlak kan worden gedacht aan acceptatie van de aandoening en aan aanpassingsproblemen op het gebied van persoonlijke relaties, school, werk en vrije tijdsbesteding.

Tenslotte bleek het ook mogelijk financiêle middelen te verwerven, waardoor de gemaakte exemplarische keuze daadwerkelijk kon worden uitgevoerd.

Kennis over diabetes mellitus wordt door huisartsen niet uitsluitend verworven in het kader van de beroepsopleiding. Voor een belangrijk deel vindt deze kennisverwerving immers plaats in het kader van de zesjarige opleiding tot basisarts, die aan de beroepsopleiding tot huisarts vooraf 
gaat. In de beroepsopleiding tot huisarts vindt een aanvulling op eerder verworven kennis over diabetes mellitus plaats, toegespitst op relevantie voor de huisartsgeneeskunde.

In de medische studie is de diagnostiek en behandeling van diabetes mellitus een relatief duidelijk afgegrensd onderdeel van de interne geneeskunde. In het veel gebruikte leerboek "Interne Geneeskunde" van Den Ottolander (4) wordt er een afzonderlijk hoofdstuk aan gewijd. In dit hoofdstuk wordt aandacht besteed aan:

- pathofysiologie

- classificatie en diagnostiek

- pathogenese

- klinische verschijnselen

- behandeling van type I diabetes mellitus

- behandeling van type II diabetes mellitus

- diabetisch coma

- late complicaties

- zwangerschap en diabetes mellitus

- intercurrente ziekten.

Wanneer men het effect van een opleidingsprogramma tot huisarts met betrekking tot de kennis over diabetes mellitus op een verantwoorde wijze wil beschrijven, is het noodzakelijk vast te stellen, welke kennis op het desbetreffende gebied al bij aanvang van de beroepsopleiding aanwezig was.

Zou men enerzijds het ingangsniveau met betrekking tot het te meten kennisgebied in kaart brengen en anderzijds het niveau aan het einde van de beroepsopleiding, dan kan men conclusies trekken over effecten van het opleidingsprogramma.

Het vergelijken van beide niveaus is op zichzelf echter niet toereikend. Vermeden dient te worden, dat in de vergelijking ook kennis wordt betrokken, die niet of niet voldoende specifiek is voor het beroep van huisarts. Om zicht te krijgen op de specifieke beroepsgebonden kennis werd een "tussenstap" geformuleerd, die hier als een tweede vraagstelling - of wellicht als een nadere uitwerking van de eerste vraagstelling - zal worden gepresenteerd. Besloten werd na te gaan, of het mogelijk was een normatieve omschrijving te geven van de kennis over diabetes mellitus, waarover huisartsen in ieder geval zouden moeten beschikken. De hierop betrekking hebbende vraagstelling werd als volgt geformuleerd:

2. Welke kennis over diagnostiek en behandeling van patiênten met diabetes mellitus dient een huisarts aan het einde van de beroepsopleiding te hebben verworven ?

Een vergelijking van de kennis, die feitelijk aanwezig is, met de kennis, die eigenlijk aanwezig zou moeten zijn, maakt het mogelijk uitspraken te doen over de kwaliteit van de opleiding, die onderwerp van onderzoek is, in dit geval de beroepsopleiding tot huisarts. Overigens mag niet op voorhand worden aangenomen, dat huisartsen en b.v. internisten het in alle opzichten met elkaar eens zullen zijn over de vraag, welke kennis een huisarts op het gebied van diagnostiek en behandeling van patiênten met diabetes mellitus dient te bezitten. Aan eventuele verschillen van inzicht in dit opzicht zal eveneens aandacht moeten worden besteed.

Dit onderzoek wil ook een antwoord proberen te geven op de vraag, op welk moment de aanwezige kennis feitelijk werd opgedaan. Een deel van de aanwezige kennis zal verworven zijn in de basisopleiding, die vooraf gaat aan de beroepsopleiding en een deel van de kennis zal verworven zijn tijdens de beroepsopleiding. Hierbij dient dan weer onderscheid gemaakt te worden tussen kennis opgedaan tijdens de terugkomdagen op de instituten en kennis opgedaan in de opleidingspraktijken. Aan dat onderscheid is in dit onderzoek geen aandacht besteed.

Om het specifieke effect van de beroepsopleiding tot huisarts met betrekking tot de kennis omtrent diabetes mellitus te kunnen vaststellen zullen tenminste de twee volgende vraagstellingen aan de orde moeten komen: 
3. Welke kennis over diagnostiek en behandeling van patiênten met diabetes mellitus hebben basisartsen, die aan een beroepsopleiding tot huisarts beginnen ?

4. Welke kennis over diagnostiek en behandeling van patiênten met diabetes mellitus hebben huisartsen, die de beroepsopleiding tot huisarts afsluiten?

Dit onderzoek wil vooral achterhalen welke effecten de beroepsopleiding tot huisarts heeft op de kennis omtrent diagnostiek en behandeling van patiênten met diabetes mellitus. Een meting aan het begin van de opleiding en een meting aan het eind van de opleiding zouden een dergelijke vraagstelling afdoende kunnen beantwoorden. Het feitelijke gegeven, dat dit onderzoek instrumenten zal opleveren voor het meten van kennis omtrent diabetes mellitus, maakt het mogelijk meer relief aan de resultaten van dit onderzoek te geven. Wanneer de te ontwikkelen toetsen ook voorgelegd zouden kunnen worden aan ervaren huisartsen, kan worden vastgesteld, of en in hoeverre het resultaat van de beroepsopleiding tot huisarts in overeenstemming is met de kennis over diabetes mellitus die bij ervaren huisartsen kan worden vastgesteld. Dit leidt tot een vijfde vraagstelling:

5. Wat zijn de verschillen en de overeenkomsten tussen recent opgeleide huisartsen en ervaren huisartsen op het gebied van kennis over diagnostiek en behandeling van patiênten met diabetes mellitus?

Bij de vaststelling van het kennisgebied, waarop bovenstaande vraagstellingen zullen worden toegepast, zal in ieder geval aandacht moeten worden gegeven aan de volgende componenten:

- allereerst zal het gaan om kennis uit de interne geneeskunde, zoals die hierboven werd aangeduid.

- daarnaast moet rekening worden gehouden met een huisartsgeneeskundige dimensie "die bij de behandeling en begeleiding van diabetespatiênten moet worden onderscheiden. Deze dimensie heeft betrekking op de integrale en continue wijze van zorgverlening door de huisarts. Concreet betekent dit, dat de huisarts in het leefmilieu van de patiênt zorg verleent gedurende een langere tijd, soms vele jaren. Bovendien heeft de huisaris zicht op bestaande, andere verstoringen van somatische, psychische of sociaal-maatschappelijke aard. Voor de te: ontwikkele ? meetinstrumenten betekent dit, dat deze typisch huisartsgeneeskundige dimensie hierin te herkennen zal moeten zijn.

6. Wat zijn de verschillen en overeenkomsten in kennis van deelnemers geaggregeerd op' instituutsniveau ?

Om de resultaten van de kennistoetsen zo goed mogelijk te kunnen interpreteren werd ten. behoeve van het onderzoek nog aandacht besteed aan de volgende aspecten:

- systematische verschillen tussen de verschillende opleidingsinstituten voor de beroepsopleiding tot huisarts werden zeker mogelijk geacht. Om deze hypothese te toetsen. werden de gegevens onder meer per instituut verzameld en geanalyseerd.

- daarnaast werd nagegaan in hoeverre per instituut onderwijs werd gegeven op het gebied van de diagnostiek en behandeling van patienten met diabetes mellitus en wat de inhoud en omvang va- i deze onderwijsprogrammals was.

Hierover wordt in hoofdstuk 5 gerapporteerd. Bijlage 4 bevat de hiervoor gebruikte vragenlijst.

7. Wat zijn de verschillen en overeenkomsten tussen huisartsen-in-opleiding onderling op het punt van speciale belangstelling voor diabetes mellitus ?

Verondersteld werd, dat individuele huisartsen-in-opleiding zich verschillend zouden kunnen verhouden tot het exemplarische onderwerp van de toetsen, bijvoorbeeld door een uitgesproken belangstelling voor het onderwerp diabetes, extra ervaring op het gebied van diabetes 
mellitus, extra aandacht voor het onderwerp door literatuurstudie en/of nascholing op dit gebied. Om dergelijke individuele verschillen op het spoor te kunnen komen, werd een korte vragenlijst hierover aan de deelnemers voorgelegd. Deze vragenlijst is opgenomen in bijlage 5.

\subsection{De methoden}

De vraagstellingen die eerder werden geformuleerd vragen om een tweetal van elkaar te onderscheiden benaderingswijzen. Waar resultaten van opleidingsprogrammals moeten worden geregistreerd ligt het voor de hand te kiezen voor een veel gebruikte en algemeen aanvaarde werkwijze: het construeren en afnemen van toetsen. Dit geldi derhalve voor de vraagstellingen $1,3,4$ en 5 . Waar de normatieve vaststelling van de noodzakelijk geachte kennis van diagnostiek en behandeling van patiênten met diabetes mellitus aan de orde is, zullen deskundigen moeten worden benaderd om bij een dergelijk normatieve vaststelling behulpzaam te zijn. Dit zal vooral ten behoeve van vraagstelling 2 noodzakelijk zijn.

Om de normatieve vaststelling van de noodzakelijk geachte kennis te realiseren werd als voigt te werk gegaan. Op basis van een literatuurstudie werd geinventariseerd welke elementen deel zouden kunnen uitmaken van de noodzakelijk geachte kennis. Over de resultaten van deze literatuurstudie werd overleg gepleegd met een aantal deskundigen op het beoogde kennisgebied van diabetes mellitus. Deze deskundigen waren in de eerste plaats huisartsen en internisten. Daarnaast werd ook overleg gepleegd met een diettist, een oogarts, een diabetesverpleegkundige, een neuroloog, een gynaecoloog en een medisch socioloog. Uit de literatuurstudie en het overleg met de deskundigen resulteerde een kennisbeschrijving in de vorm van een "Kennispakket" (zie bijlage 3), dat werd voorgelegd aan een panel van huisartsen. De voorgelegde ken risbeschrijving werd door dit panel van commentaar voorzien en in een volgende fase geaccordeerd. Op deze wijze kwam de normatieve kennisbeschrijving tot stand, zoals die werd geformuleerd voor de tweede vraagstelling.

Om de vraag te kunnen beantwoorden of het mogelijk is het effect van een opleidingsprogramma tot huisarts - aan de hand van een exemplarisch voorbeeld - op een verantwoorde wijze te beschrijven, wordt gekozen voor het construeren en afnemen van toetsern, die op geleide van het tot stand gebrachte "Kennispakket" werden samengesteld. Hierbij dient te worden aangetekend dat de resultaten die op dit terrein van de zorg voor patiénten met een, chronische aandoening - namelijk diabetes mellitus - niet vanzelfsprekend te generaliseren zijn naar andere gebieden in de huisartsenzorg. Bij het construeren van boven-genoemde toetsen moet zoveel mogelijk rekening worden gehouden met de beroepspraktijk van de Nederlandse huisarts, omdat daarop het opleidingsprogramma moet zijin afgestemd.

Vanzelfsprekend zullen de te ontwikkelen toetsen ook moeten voldoen aan gangbare criteria van betrouw'baarheid, validiteit en praktische bruikbaarheid (5). Bovendien zullen de te ontwikkelen toetsen geschikt moeten zijn voor afname bij betrekkelijk grote aantallen deelnemers aan opleidingsprogramma's.

In hoofdstuk $4 \mathrm{zal}$ nader worden ingegaan op de aspecten, die ten aanzien van het ontwikkelen van toetsen van belang zijn.

Na het vervaardigen van de toetsen op basis van de domeinbeschrijving uit het "Kennispakket" werd het eerder genoemde panel nogmaals ingeschakeld om de afstemming tussen Kennispakket en toetsen te beoordelen. Deze procedure wordt in hoofdstuk 4 verder besproken. De vraagstellingen 3 en 4 werden onderzocht met behulp van twee toetsen over diabetes mellitus, die verder zullen worden aangeduid met de term "diabetestoetsen". Door de geconstrueerde diabetestoetsen voor te leggen aan huisartsen-in-opleiding zowel aan het begin als aan het eind van de beroepsopleiding, werden gegevens verzameld ten behoeve van vraagstelling 3 en 4 .

Vraagstelling 5 werd onderzocht door een groep van 62 ervaren huisartsen deel te laten nemen aan toets 1 . Hun resultaten werden vervolgens vergeleken met die van de huisartsen-in- 
opleiding: Om vraagstelling 6 te kunnen beantwoorden werden de toetsresultaten van de huisartsen-in-opleiding per instituut verzameld en vergeleken.

Voor het beantwoorden van vraagstelling 7 werd gebruik gemaakt van de toetsscores van de deelnemers. Door middel van de Chi kwadraat-toets werd onderzocht of bepaalde deelnemerskenmerken samenhang vertoonden met hoge of lage toetsscores.

Bij de constructie van de benodigde toetsen deed zich de vraag voor, of de basisopleiding geneeskunde de studenten voorziet van de kennis, die het meest relevant is voor toepassing in de huisarts-praktijk. Dat dit niet zonder meer het geval behoeft te zijn, werd verondersteid op een tweetal gronden:

- de medische basisopleiding behoeft het beoogde nomatieve niveau niet te bereiken, omdat nog een beroepsopleiding tot huisarts volgt. Anders gezegd: het product vani de basisopleiding behoeft niet te voldoen aan het niveau voor het eindproduct van het totale opleidingstraject;

- in de basisopleiding zijn vooral internisten verantwoordelijk voor hel overdragen van de gewenste kennis. Dit zou tot gevolg kunnen hebben, dat een internistische kijk op diabetes mellitus, dat wil zeggen gevormd door ervaringen vit de beroepsuitoefening als internist in de basisopleiding geneeskunde domineert. Aanvullingen hierop en modificaties hiervan in de beroepsopleiding tot huisarts kunnen dus nodig zijn.

Op grond van deze laatste overwegingen zou verwacht kunnen worden, dat kennis aarı het einde van de basisopleiding geneeskunde, na het volgen van de co-assistentschappen, uit een relatieve oververtegenwoordiging bestaat van kennis op het terrein van de insuline-afhankelijke diabetes (afgekon als LADM of ook wel type I diabetes genoemd) terwijl kennis op het terrein van de niet van insuline afhankelijke diabetes mellitus (NIADM of type II diabetes genoemd) wellicht ondervertegenwoordigd is. Objectieve gegevens om deze veronderstelling te staven zijn niet in de literatuur gevonden. In hooldstuk 5 zal worden bezien, of dergelijke verwachtingen bevestigd worden door de verzamelde onderzoeksgegevens. Daarbij zal vooral het resultaat varı de beginmeting van belang zijn.

Verwacht wordt uiteraard ook, dat de huisartsen-in-opleiding aan het einde: van de beroepsopleiding in kennis op het gebied van diabetes mellitus vooruit zijn gegaan. Dit zou tot uitdrukking moeten komen in hogere scores op de kennistoets. Daarbij mag dan tevens worden verwacht, dat de resultaten aan het einde van de beroepsopleiding in hoofdzaak worden bereikt op basis van kenniselementen, die voor de huisartspraktijk wenselijk worden geacht.

\section{Literatuur bij hoofdstuk 2}

1. Chronische ziekten in het jaar 2005. Deel 1 Scenarios over diabetes mellitus 1990-2005. Stuurgroep Toekomstscenarios Gezondheidszorg. Amsterdam: Bohn, Schelterna \& Holkema, 1990.

2. Springer MP (red). Basistakenpakket van de huisarts. Utrecht: Landelijke Huisartsen Vereniging, 1987.

3. Van Ree, J. Risicostratificatie bij het behandelen van aandoeningen in de huisartspraktijk. Maastricht: Rijksuniversiteit Limburg, 1991. Inaugurele rede.

4. Den Ottolander GJH (red). Interne geneeskunde. 9e druk, Utrecht: Bohn Scheltemat \& Holkem., 1989.

5. De Groot AD, Van Naersen RF. Studietoetsen deel 1 en 2. 3e druk, Den Haag: Mouton Publishers, 1977. 


\section{Hoofdstuk 3}

\section{Diagnostiek, behandeling en controle van Niet Insuline Afhankelijke Diabetes Mellitus in de huisartspraktijk en het kennispakket.}

Het onderwerp van deze studie heeft naast een meettechnisch aspect - het ontwikkelen van toetsen - ook een inhoudelijk aspect, namelijk de behandeling van patiènten met diabetes mellitus in de huisartspraktijk.

In dit hoofdstuk zal de inhoud van de diabetesbehandeling en de rol van de huisarts op dit terrein centraal staan. Als introductie zal kort worden ingegaan op enkele centrale concepten uit de pathofysiologie, die van belang zijn voor een beter begrip van de aandoening. Voor cen volledige beschrijving wordt naar de aangehaalde literaturur verwezen.

\subsection{Onderscheid tussen Type I en Type II diabetes mellitus en de rol van insulineresistentie.}

\subsubsection{Type I diabetes mellitus}

Type I diabetes is een zich snel ontwikkelende ernstige aandoening die, wanneer deze niet behandeld wordt, tot de dood leidt door een absoluut tekort aan het hormoon insuline. Dit hormoon, dat in de B-cellen van het pancreas wordt geproduceerd en in het bloed wordt afgescheiden, heeft als belangrijkste werking het transport van glucose vanuit het bloed door de wand van de lichaamscellen mogelijk te maken.

De diagnose diabetes mellitus type I wordt gesteld op grond van het sterk verhoogde bloedglucosegehalte in combinatie met het aantonen van ketoacidose of acetonurie en de meestal daarmee gepaard gaande klachten, zoals moeheid, polyurie (veel plassen), polydipsie (overmatig vicl drinken), een malaisegevoel en jeuk. De patiênt is na korte tijd volledig afhankelijk van exogeen insuline, dat dagelijks een of meer malen per injectie moet worden toegediend. Daarom spreekt men ook wel van Insuline Afhankelijke Diabetes Mellitus (LADM, of Insulin Dependent Diabetes Mellitus (IDDM)). Dit ziektebeeld openbaart zich overwegend voor het veertigste levensjaar.

\subsubsection{Iype II diabetes mellitus}

Type II diabetes of Niet van Insuline Afhankelijke Diabetes Mellitus (NIADM of Non Insulin Dependent Diabetes Mellitus (NIDDM)), kent een heel ander beloop. De bloedglucosewaarde is eveneens verhoogd, maar vaak heeft de patiênt geen of weinig klachten. Deze klachten worden echter bij grondig doorvragen wel regelmatig tot uiting gebracht. Voorbeelden zijn moeheid, dorst, minder goed zien.

De patiênt h-efit een relatief tekort aan insuline, dat wil zeggen: vaak is de eigen insulineproductie normaal of zelfs verhoogd, maar deze blijkt door het optreden van een sterk toegenomen resistentie tegen de werking van insuline toch onvoldoende te zijn voor het handhaven van de bloedglucosespiegel binnen de normale waarden.

Type II diabetes komt vooral voor bij oudere mensen, die tegelijkertijd vaak een te hoog lichaamsgewicht hebben. De behandeling is vooral gericht op verandering van voedingsgewoonten en kan zonodig ondersteund worden door het voorschrijven van bloedglucoseverlagende tabletten. Een belangrijk deel van de met orale medicatie behandelde patiénten blijkt na langere tijd toch behandeling met insuline nodig te hebben. Dit fenomeen staat bekend als het secundair falen op bloedsuiker verlagende orale medicatie. 


\subsubsection{De rol vi.n insulineresistentie}

Met betrekking tot de pathofysiologie van diabetes zijn een tweetal - hierboven al genoemdeconcepten van groot belang voor het verwerven van inzicht in het ontstaan en verloop van de aandoening. Allereerst is het begrip insuline deficiêntie van belang, dat betrekking heeft op het in absolute zin tekort schieten van de insuline productie van de patiênt in relatie tot de hoeveelheid, die nodig is voor het adequaat laten verlopen van het glucosemetabolisme.

Daarnaast is tevens sprake van insulineresistentie. Deze term heeft betrekking op een verminderde gevoeligheid voor de werking van insuline. Dit resulteert in een toenemende behoefte aan insuline.

De door insuline deficiéntie en -resistentie onstane hyperglycaemie leidt tot een klinisch waarneembare bloedglucose verhoging.

Moller en Flicr gaan in een recent artikel (1) nader in op de rol van insulineresistentie: insuline oefent zijn werking op diverse plaatsen in het menselijk lichaam uit. In het weefsel van de lever remt insuline de produktie van glucose, door remming van de gluconeogenese en de glucogenolyse. Glucose wordt in de lever opgeslagen als glycogeen, dit proces wordt bevorderd door insuline. In de spieren en in het vetweefsel bevordert insuline de opname, opslag en gebruik van glucose. Hierbij zijn op celniveau specifieke insulinereceptoren aanwezig. Bij insulineresistentie gaat het om een verminderde respons van het lichaam met betrekking tot het gelijkmatig houden van de glucosespiegel in het bloed. Bij een bepaalde concentratie van insuline in het bloed blijft de glucosewaarde te hoog. Om de waarde weer tot het normale niveau terug te krijgen is extra insuline nodig.

Dit mechanisme leidt tot extra aanmaak van insuline in het pancreas. De capaciteit van het pancreas is echter niet onbeperkt; op een bepaald punt is de maximale aanmaak bereikt. Bij patiênten met type II diabetes mellitus is waarschijnlijk sprake van een subtiel samenspel van beide bovengenoemde factoren (resistentie en onvoldoende capaciteit) waardoor de patient op een bepaald moment niet meer in staat is om de glucosespiegel in het bloed binnen het normale traject te houden. Het hebben van overgewicht leidt waarschijnlijk tot een minder goed functioneren van de insulinereceptoren in de celwand.

In een overzichtsartikel bespreekt Reaven (2) het mogelijke verband tussen insulineresistentie en het optreden van hypertensie en coronarialijden. Hij maakt aannemelijk dat het langdurig bestaan van insuline resistentie, met de daarbij horende verhoogde uitscheiding van insuline het ontstaan van hypertensie bevordert. Deze redenering legt een verband tussen afwijkingen, zoals die te vinden zijn bij diabetes mellitus en een toename van de kans op hart- en vaatziekten.

\subsection{Taken van de huisarts volgens het Basistakenpakket}

Het Basistakenpakket van de Landelijke Huisartsen Vereniging (LHV) (3) is een uitvoerig document dat een opsomming geeft van het werkterrein van de huisarts in Nederland en dat geaccordeerd is door de beroepsgroep. Op het punt van diabetes mellitus bevat het document een tweetal duidelijke passages. De eerste passage heeft betrekking op aparte taken binnen de zorg, voor patiênten met een chronische aandoening. Omdat diabetes mellitus expliciet wordt gerekend tot de chronische aandoeningen zijn de in dat kader opgesomde aparte taken ook in dit verband relevant. De volgende taken worden genoemd:

- het bewaken van het ziekteproces,

- het samenwerken met andere hulpverleners,

- het bewaken van medicamenteuze therapie,

- het zo nodig nemen van preventieve maatregelen,

- het nemen van maatregelen tot behoud en ter verbetering van de validiteit,

- het schenken van voldoende aandacht aan de invloed van de aandoening op de andere gezinsleden, 
- het tot stand helpen brengen van voldoende verzorging en verpleging,

- het oog hebben voor de psychische, sociale en religieuze aspecten van het chronisch ziekzijn, in het bijzonder de gezinsinteracties en de financieel-economische gevolgen.

De huisarts dient patiênten met type Il diabetes zelfstandig te kunnen behandelen, als onderdeel van het kunnen behandelen van de meest voorkomende chronische aandoeningen.

Het Basistakenpakket noemt als expliciete taken bij diabetes mellitus:

- het is de taak van de huisarts om type II diabetes zelfstandig te diagnostiseren;

- het is de taak van de huisarts patiênten met type II diabetes zelfstandig te behandelen;

- het is de taak van de huisarts patiênten met type II diabetes systematisch te controleren;

- het is de taak van de huisarts zijn eigen diagnostische en therapeutische mogelijkheden bij type II diabetes adequaat in te schatten, zijn taakafgrenzing te kennen en zonodig zorg te dragen voor adequate verwijzing;

- het is de taak van de huisarts type 1 diabetes in eerste instantie te diagnostiseren en patienten met de aandoening in samenwerking met de internist te behandelen. "

Over de taak van de huisarts bij type I diabetes worden in het Basistakenpakket van de LHV de volgende uitspraken gedaan. Bij het begeleiden van type I patiènten ligt het accent vooral op het tijdig onderkennen en adequaat verwijzen van de patiènt. Daarnaast dient de huisarts adequaat te kunnen handelen bij acute ontregeling van type 1 diabetespatięnten, zowel bij hypoglycaemische als bij hyperglycaemische verschijnselen.

Hypoglycaemie betekent een te laag glucosegehalte in het bloed. Dit kan onder meer leiden tot klachten als transpireren, bleek worden en bewusteloos raken. Bij een hyperglycaemie is sprake van een ontregeling van de diabetes, waarbij veel te hoge glucosespiegels in het bloed ontstaan en in geval van een keto-acidotische ontregeling ook ketonlichamen in de urine aanwezig zijn. Dit leidt tot klachten als sufheid en polyurie, waarbij de patiênt een afwijkende ademhaling vertoont, nl. de Kussmaulse ademhaling. Hierbij wordt sneller en dieper dan normaal geademd. Om te kunnen differentiẻren tussen een hypo- en een hyperglycaemisch coma dient de huisarts een snelle bloedglucosebepaling bij de patiènt aan huis te kunnen verrichten "om dan vervolgens passende maatregelen te kunnen nemen. Bij hypoglycaemie zal met behulp van een glucagon- of een glucose-injectie het probleem snel op te lossen zijn; bij een hyperglycaemisch coma zal meestal direct opname nodig zijn, aangezien een dergelijk coma gepaard gaat met zodanig uitgebreide metabole veranderingen dat intensieve zorg in een ziekenhuis onvermijdelijk is.

De huisarts zal eventuele andere, niet rechtstreeks met diabetes mellitus gekoppelde aandoeningen, bijvoorbeeld griep of een verstuikte enkel, evengoed bij een patiênt met type I diabetes gepresenteend krijgen. Dit is nu eenmaal het gevolg, vain de rol van de huisarts als eerste-lijns hulpverlener. Daarnaast zal hij door zijn positie als gezinsarts vaak ook de partner en andere familieleden van een diabetespatient kennen. Hierdoor is hij in staat om aandacht te besteden aan de. wijze waarop met deze chronische aandoening wordt omgegaan in het gezin en in welke mate de. partner al dan niet gebukt gaat. onder de druk van de bij de ziekte behorende leefregels en beperkingen, zoals het aanhouden van een regelmatig dagritme met een vrij constante balans tussen inspanning, voeding en insulinetoediening en het regelmatig coniroleren van de bloedglucosewaarde.

Bijna altijd is een internist (of in geval van jeugdige patiêntjes een kinderarts) de hoofdbehandelaar bij type I diabetespatiênten.

In 1979 verscheen een themanummer over diabetes mellitus in de serie Huisarts $\&$ Praktijk. Huisarts \& Praktijk is een bijlage van Huisarts en Wetenschap (4). In dit themanummer werd een duidelijke poging gedaan om te komen tot een uniformering van de werkwijze van huisartsen bij de behandeling van diabetes mellitus.

Wie dit themanummer anno 1994 nog eens doorleest, ziet enerzijds hoeveel er in ruim vijtien 
jaar veranderd is in de aanpak (bijvoorbeeld de kwantitatieve bepaling van de glucoseuitscheiding in de urine is geheel in onbruik geraakt), maar anderzijds hoe sterk de contouren van de standaard van 1989 al in de beschrijving van 1979 kunnen worden herkend.

In het Kennispakket (bijlage 3 bij dit proefschrift) worden enkele belangrijke richtlijnen gepresenteerd voor de vraag, hoe de huisarts diagnostiek en behandeling van type II vorm zou moeten gever. De onderbouwing van deze richtlijnen zal in dit hoofdstuk worden toegelicht aan de hand van de literatuur.

Het kennispakket bevat een zestal hoofdstukken over de voor de huisartspraktijk belangrijke aspecten van diabetes mellitus. Nadat in hoofdstuk 1 een diagnostische classificatie en een protocol voor opsporing en behandeling van type II diabetes mellitus wordt gegeven, gaat hoofdstuk 2 in op signalen van ontregeling van diabetes mellitus en het daarbij passende beleid. Met opzet is geprobeerd om vooral de praktische, in de dagelijkse praktijk belangrijke punten naar voren te halen en zo weinig mogelijk in te gaan op de achterliggende theoretische concepten. Dit maakt het boekje bruikbaar als orièntatie voor huisartsen bij nascholing, waarbij pathofysiologie vaak als overbodige ballast wordt ervaren. In hoofdstuk 3 wordt vitleg over behandeling en begeleiding gegeven met betrekking tot dieet en medicatie, genees-middelinteracties, voorlichting en maatschappelijke aspecten.

In hoofdstuk 4 wordt ingegaan op de late gevolgen van diabetes mellitus, met name hypertensie, oogcumplicaties, neuropathie, voetproblemen, nefropathie en huidafwijkingen. In hoofdstuk 5 wordt heel beknopt het onderwerp diabetes en zwangerschap aangestipt. Het laatste hoofdstuk gaat over de organisatie van de zorg voor diabetespatiénten in de huisartspraktijk. Een literatuurlijst met voor huisartsen relevante literatuursuggesties vormt de afsluiting van het nog geen 40 pagina's tellende boekje. Het Kennispakket is in 1987 uitgegeven door de Stichting Diadata te Maastricht en werd in 1988 herdrukt. Deze iets gewijzigde tweede druk is als bijlage 1 opgenomen. Na de introductie van de NHG-standaard Diabetes Mellitus werd het Kennispakket onder redactie van het NHG in 1990 opgenomen in de reeks NHGpublicaties deskundigheidsbevordering.

\subsection{Epidemiologie van type II diabetes mellitus in Nederland.}

In het onderzoek van Voorn (5) blijkt diabetes mellitus type II bij de tien meest voorkomende chronische aandoeningen in de huisartspraktijk te horen bij beide geslachten boven de leeftijd van 50 jaar. Crebolder komt in zijn onderzoek onder bekende diabetespatiênten van het eigen gezondheidscentrum in Venlo tot een prevalentie van 1,99\% (6). Cromme komt bij een bevolkings-onderzoek in Twello onder een groep van 460 personen ouder dan 64 jaar tot de zeer hoge prevalentie van $31 \%(7)$. Hij onderzocht deze populatie slechts eenmaal, door een orale glucosetolerantietest (OGII) met 75 gram glucose uit te voeren. De capillaire bloedmonsters werden met een glucose teststrip en afleesapparaat onderzocht. Verhoeven komt in zijn onderzoek onder de bevolking van Heerde, voor zover reeds vooraf bekend met type II diabetes mellitus op een prevalentie van $1,6 \%$ uit ( 8 ).

Als vuistregel wordt vaak een percentage voor de prevalentie van 2 gehanteerd. Dit betekent, dat diabetes mellitus een veel voorkomende aandoening is, die ook in de ongeselecteerde populatie van cen huisartspraktijk veelvuldig aangetroffen zal worden. Gemiddeld zijn in een normpraktijk van 2350 patiènten dus 47 patiénten met diabetes mellitus te verwachten, waarbij ongeveer 10 niet als zodanig bekend zijn, als we de gegevens uit de onderzoeken van Crebolder en Verhoeven combineren. Deze 10 niet geidentificeerde patiénten zullen, gezien de eerder beschreven ziektekenmerken, waarschijnlijk lijden aan type II diabetes mellitus.

Het onderzoek van Cromme maakt nog eens extra duidelijk, dat diabetes mellitus type II een aandoening is die vooral oudere mensen treft. De stuurgroep Toekomstscenarios Gezondheidszorg zet in het Scenario-rapport over diabetes mellitus ( 9 ) uiteen, dat er in het jaar 2005 ongeveer 355.000 Nederlanders zullen zijn met diabetes mellitus. Dit is een toename van 
$50 \%$ ten opzichte van het aantal in 1990 . Deze forse stijging wordt vooral veroorzaakt door de te verwachten toename van het aantal bejaarden en hoogbejaarden in de bevolking.

\subsection{Diagnostiek van diabetes mellitus}

Voor de diagnostiek van diabetes mellitus worden internationaal de WHO-criteria uit 1985 gebruikt (10). Deze criteria gaan uit van bloedsuikerbepalingen in nuchtere toestand of twee uur na orale belasting met 75 gram glucose (de orale glucosetolerantietest of OGTT).

Tabel 1 WHO-criteria voor classificatie van diabetes mellitus

\begin{tabular}{|c|c|c|}
\hline 1. & $\begin{array}{l}\text { Diabetes mellitus aanwezig: } \\
\text { nuchtere bloedglucose } \\
\text { en/of twee uurs waarde in capillair bloed }\end{array}$ & $\begin{array}{ll}> & 6,7 \mathrm{mmol} / \mathrm{L} \\
> & 11,1 \mathrm{mmol} / \mathrm{L}\end{array}$ \\
\hline 2. & $\begin{array}{l}\text { Gestoorde glucosetolenantie: } \\
\text { nuchtere bloedglucose } \\
\text { en twee uurswaarde in capillair bloed tussen }\end{array}$ & $\begin{array}{l}6,7 \mathrm{mmol} / \mathrm{L} \\
7,8 \mathrm{mmol} / \mathrm{L} \text { en } 11,1 \mathrm{mmol} / \mathrm{L}\end{array}$ \\
\hline 3. & $\begin{array}{l}\text { Geen diabetes mellitus: } \\
\text { nuchtere bloedglucose } \\
\text { en twee uurswaarde in capillair bloed }\end{array}$ & $\begin{array}{ll}< & 6,7 \mathrm{mmol} / \mathrm{L} \\
< & 7,8 \mathrm{mmol} / \mathrm{L}\end{array}$ \\
\hline
\end{tabular}

Deze classificatie bevat dus een tussengroep van patiênten met een gestoorde glucosetolerantie, zonder dat deze groep als diabetespatiênt wordt geêtiketteerd. Dit is een groot voordeel ten opzichte van eerdere classificaties, gezien de vele negatieve psychische en maatschappelijke konsekwenties die verbonden zijn aan een dergelijke etikettering.

Bij een nuchtere bloedglucosewaarde die bij herhaling lager is dan $5,6 \mathrm{mmol} / \mathrm{L}$ is er veelal geen sprake van diabetes mellitus. Nuchtere waarden tussen $5,6 \mathrm{mmol} / \mathrm{L}$ en $6,7 \mathrm{mmol} / \mathrm{L}$ kunnen passen bij een gestoorde glucose tolerantie of bij diabetes mellitus. In deze gevallen is de orale glucose tolerantie test van nut om de waarden na belasting te meten om zo tot een diagnose te komen. In de praktijk is de rol van de OGTI slechts beperkt, aangezien bij de meeste patienten de nuchtere bloedglucose waarden dikwijls al direct boven de $6,7 \mathrm{mmol} / \mathrm{L}$ uitkomen.

Uit de Bedford studie (11) is duidelijk geworden dat slechts een klein deel van de in deze tussengroep ingedeelde patiênten op den duur echt diabetes mellitus krijgt. De kans op het ontwikkelen van diabetes mellitus is echter wel groter dan in de algemene bevolking. Het risico op hart-en vaataandoeningen in de groep met gestoorde glucosetolerantie was ongeveer 1,5 a 2 maal zo hoog als bij gezonde personen.

Voor zwangerschapsdiabetes, dat als een apart ziektebeeld kan worden beschouwd, gelden afwijkende criteria voor glucosetolerantie. Aangezien de begeleiding van zwangerschaps-diabetes doorgaans niet door de huisarts zal gebeuren, wordt er in dit bestek verder geen aandacht aan besteed.

\subsection{Behandeling van type II diabetes mellitus}

Wolffenbuttel geeft in zijn dissertatie (12) de volgende behandeldoelen voor de behandeling van type II diabetes mellitus:

- het vrijwaren van klachten, die veroorzaakt worden door hyperglycaemie;

- het verbeteren van de kwaliteit van leven;

- het verbeteren van de verstoringen in de stofwisseling te weten: 
- bloedglucosewaarden terugbrengen binnen normale grenzen,

- herstellen van de afwijkingen in de vetstofwisseling (cholesterol, triglyceriden), en

- corrigeren van de hyperinsulinaemie;

- het reduceren van het overgewicht, indien aanwezig;

- het normaliseren van verhoogde bloeddruk;

- het verminderen van het voorkomen van late gevolgen van diabetes mellitus.

Als eerste stap is voedingsadvies (13) hiervoor aangewezen in combinatie met een advies om meer te bewegen (14).

De Europese consensus zoals geformuleerd door de EUR NIDDM-Policy Group (15) geeft de volgende richtlijnen voor controle en behandeling:

Objectives of treatment:

- relief of symptoms,

- prevention of acute and chronic complications,

- avoidance of excess mortality,

- treatment of accompanying disorders,

- improvement of the quality of life.

Means for achieving metabolic control:

- dietary adjustments,

- reduction of overweight in the obese,

- hypolipidaemic therapy,

- adequate physical activity,

- oral hypoglycaemic agents,

- insulin,

- education.

Het dieet dient de volgende verdeling van macro-nutriènten te bevatten: $50-55 \%$ koolhydraten, $30-35 \%$ vetten en $15 \%$ eiwit. Deze voeding is rijker aan koolhydraten en armer aan vet dan gangbaar in Nederland. De koolhydraten dienen bij voorkeur in de vorm van vezelrijke producten te worden aangeboden (b.v. bruin brood, aardappelen, muesli). Heine en Schouten (16) maken duidelijk, dat het diabetesdieet gebaseerd is op voedingsadviezen, die ook voor de gezonde bevalking gelden, en als zodanig gezien, nauwelijks beperkingen met zich meebrengen. Nieuwerihuijzen Kruseman en Sels (17) tekenen hierbij aan, dat een hoog gehalte: aan koolhydmaten (meer dan 55\%) en extra vezel in de voeding leidt tot een minder aantrekkelijk dieet en op zich ook niet nodig is, mits de vetten in de voeding bestaan uit onverzadigde vetzuren. Speciaal diabetespatiẻnten met hypertriglyceridemie zijn niet gebaat bij een koolhydraatrijk dieet, aangezien dit hun triglyceridespiegel nog verder kan verhogen.

Het CBO rapport Voedingsadvies bij diabetes (18) nuanceert dit nog verder in het volgende voedingsadvies. Men stelt voor om het aandeel, uitgedrukt in energetische waarde van de macronutriênten als volgt te adviseren: $35 \%$ van de energetische waarde dient door vetten geleverd te worden, waarbij het percentage verzadigd vet niet hoger mag zijn dan $10 \%$. Vervanging van het surplus aan verzadigd vet kan geschieden door toename van het aandeel van de koolhydraten en door toename van onverzadigd vet.

De hoeveelhe. 1 cholesterol dient niet hoger te zijn dan $300 \mathrm{mg}$ per dag.

Voor de eiwitten wordt een aandeel van 10-15\% in de energetische waarde aanbevolen, hierbij heeft eiwit afkomstig uit plantaardige voedingsmiddelen de voorkeur. Wat betreft het aandeel van de koolhydraten in de voeding adviseert men een hoeveelheid van $50 \%$ met ongeveer 30 gram voedingsveze!. 
Regelmatig bewegen, waarbij gedacht moet worden bijvoorbeeld aan dagelijks ongeveer een uur wandelen, heeft een gunstig effect op de gevoeligheid voor insuline, op cholesterol- en triglyceridenspiegels en op hypertensie.

\subsection{Medicamenteuze therapie}

Als eerste keuze raadt de EUR NIDDM-Policy Group de kortwerkende sulfonylureum preparaten aan. Dit zijn medicamenten, die de aanmaak van insuline in het pancreas stimuleren.

Het gebruik van biguanidepreparaten, waarvan in Nederland alleen het metformine nog beschikbaar is, wordt uitsluitend gereserveerd voor patienten met overgewicht die jonger zijn dan 65 jaar.

Metformine is vooral werkzaam bij de opname van insuline in de cel. Aangezien cen levensbedreigende doch zeer zelden voorkomende bijwerking van dit middel de lactaatacidose is en dit beeld vooral voorkomt bij oudere patienten in een slechte algemene toestand met leveren of nierinsufficièntie, is de genoemde leeftijdsgrens expliciet gesteld:

Bij falen van de orale medicatie, afgemeten aan het niet bereiken van onderstaande streefwaarden voor de bloedglucose, moet op behandeling met insuline worden overgegaan.

\subsection{Controle}

In de gezondheidszorg is het gebruikelijk om voor controle van patiênten met chronische aandoeningen een termijn van drie maanden aan te houden. Bij diabetespatiênten worde levens een uitgebreide jaarlijkse controle bepleit.

Tijdens de driemaandelijkse controle dient het gewicht bepaald en de bloeddruk gemeten te worden. Het zewicht is een indicator van dieettrouw, de bloeddruk is een belangrijke indicator voor het optreden van hart-en vaataandoeningen.

Bij de jaarlijkse controle raadt men verder aan om naast de bloedglucose ook Hbalc, cholesterol en triglyceriden, eiwituitscheiding in de urine en aanwezigheid van ketonlichamen in de urine regelmatig te bepalen.

Daarnaast dient elke diabetespatiênt regelmatig de oogarts te bezoeken.

Tabel 2 Normen voor succesvolle behandeling volgens de EUIR NIDDM Policy Group richtlijnen

\begin{tabular}{llll}
\hline & goed & acceptabel & slecht \\
\hline $\begin{array}{l}\text { nuchtere } \\
\text { bloedglucosewaarde in mmol/: }\end{array}$ & $<6,7$ & $6,7-7,8$ & $>7,8$ \\
$\begin{array}{l}\text { bloedglucosewaarde } \\
\text { postprandiaal in mmol/: }\end{array}$ & $<8,9$ & $8,9-10$ & $>10$ \\
\hline
\end{tabular}

Als we bovenstaande gezaghebbende aanbevelingen vergelijken met de inhoud van het Kennispakket voor de behandeling van diabetes mellitus in de huisartspraktijk, dan dient allereerst te. worden vermeld dat een deel van bovenstaande literatuur ten tijde van het schrijven van de eerste versie van het kennispakket (1984 -1985) nog niet beschikbaar was.

In de eerste druk van het Kennispakket, waarop de diabetestoetsen gebaseerd zijn, werd meer nadruk gelegd op de bepaling van de bloedglucosewaarde twee uur na een maaltijd. Later, in de 
tweede druk, werd het belang van de nuchtere bepaling meer naar voren gehaald. Andere veranderingen betroffen details als de lengte van de periode waarin het effect van een dieetvoorschrift afgewacht moest worden en het interval tussen twee controles bij de oogarts.

$\mathrm{Na}$ bewerking volgde in 1988-1989 een veranderde derde druk. Hierin werd de NHGstandaard opgenomen. Dit resulteerde feitelijk in een grote overeenkomst met de reeds genoemde Europese richtlijnen, die voor internisten geformuleerd zijn.

Verschillen met de EUR-richtlijnen zijn, dat in de NHG-standaard:

- de Hbalc bepaling niet genoemd wordt, zelfs niet bij de jaarlijkse controle

- de bloeddruk minder frequent gemeten wordt

- minder aandacht besteed wordt aan de vetstofwisseling

- meer expliciete criteria voor streefgewicht vermeld worden

- gebruik van metformine niet enkel gereserveerd wordt voor patiênten met duidelijk overgewicht, maar ook als additioneel preparaat na falen van sulfonylureumpreparaten.

In grote lijnen blijkt het Kennispakket, waarop de diabetestoetsen gebaseerd zijn, goed aan te sluiten op de Europese consensus. Gezien de zich verder ontwikkelende inzichten over adequate parameters van de metabole instelling bij diabetes mellitus, in het bijzonder met betrekking tot de betrekkelijke informatie, die een eénmalige bepaling van de nuchtere bloedglucosespiegel oplevert, lijkt het introduceren van de Hbalc bepaling in de huisartspraktijk aan te bevelen (19).

Het behandelen van patienten met insuline is bij huisartsen nog zeker niet gebruikelijk. Daarom wordt daarop in het Kennispakket niet nader ingegaan. Waarschijnlijk zal de huisarts in de komende jaren steeds meer geconfronteerd worden met dit aspect en zal ook voor de therapie met insuline een richtlijn moeten worden opgesteld.

Heine (20) concludeert dat ongeveer 10-15\% van alle type II diabetespatiènten uiteindelijk met insuline behandeld zal moeten worden. Gezien de grote aantallen patiēnten, waarmee we in de toekomst op grond van dergelijke prognoses rekening moeten houden, zal de Nederlandse huisarts zich ook vertrouwd moeten maken met de beginselen van een goede behandeling van type II diabetespatiènten met insuline.

\section{Literatuur bij hoofdstuk 3}

1. Springer MP (red). Basistakenpakket van de huisarts. Utrecht: Landelijke Huisartsen Vereniging, 1983.

2. Moller DE, Flier JS. Insulin resistance-mechanisms, syndromes, and implications. N Engl J Med 1991;325: 938-48.

3. Reaven GM. Role of Insulin Resistance in Human Disease. Diabetes1988;37:1595-1606.

4. Diabetes Mellitus Huisarts en Wetenschap 1979; 22 (supplement Huisarts \& Praktijk. 3).

5. Voorn I. Chronische ziekten in de huisartspraktijk. Utrecht: Bunge, 1983.

6. Crebolder H, Van Eyndhoven M. De begeleiding van type II diabeten. Huisarts en Wetenschap 1986; 29: supplement: 16-19.

7. Cromme PVM. Glucose intolerance in a typical Dutch community. [dissertatie] Bussum: Medicom, 1991. 
8. Verhoeven S. Behandeling, controle en metabole instelling van patiènten met diabetes mellitus type II en de prevalentie van late complicaties bij deze patiènten. [dissertatie]. Rotterdam: Erasmus Universiteit Rotterdam, 1989.

9. Stuurgroep Toekomstscenarios Gezondheidszorg. Chronische ziekten in het jaar 2005. Deel 1 Scenarios over diabetes mellitus 1990-2005. Amsterdam: Bohn Scheltema \&Holkema, 1990.

10. WHO Study group on diabetes mellitus. Technical Report Series 727, 1985.

11. Keen H, Jarrett RJ, MeCartney P. The ten-year follow-up of the Bedford survey (19621972): glucose tolerance and diabetes.

Diabetologia 1982; 22: 73-8.

12. Wolffenbuttel BHR. Type 2 diabetes mellitus, pathology and treatment. [dissertatie] Maastricht: Thesis, 1991.

13. Wales JK. Treatment of type 2 (non-insulin-dependent) diabetic patients with diet alone. Diabetolugia 1982; 23: 240-5.

14. Schneider SH, Ruderman NB. Exercise and NIDDM. Technical Review. Diabetes Care, 1990;13: 785-9.

15. Alberti KGMM, Gries FA. Management of non-insulin-dependent diabetes mellitus in Europe: a consensus view. Diabetic Med 1988; 5:275-81.

16. Heine RJ, Schouten JA. Het diabetesdieet: niet anders dan voeding voor gezonde mensen. Ned.Tijdschr Geneeskd 1984; 128: 1524-28.

17. Nieuwenhuijzen Kruseman AC, Sels JPJE. Dietary management of diabetes mellitus reconsidered. Editorial. Netherlands Journal of Medicine 1991; 38:231-235.

18. Voedingsadvies bij diabetes: Symposium gehouden op 6 november 1992. Georganiseerd door het Centraal Begeleidingsorgaan voor de Intercollegiale toetsing in samenwerking met de Diabetes Vereniging Nederland en Nederlandse Vereniging van Diettisten. Utrecht: CBO 1993

19. Nieuwenhuijzen Kruseman $A C$, Reactie op de diabetesstandaard.

Huisarts en Wetenschap 1989; 32:190

20. Heine RJ. Insulin treatment of non-insulin-dependent diabetes mellitus. Bailliere's Clinical Endocrinology and Metabolisme 1988; 2: 477-92. 


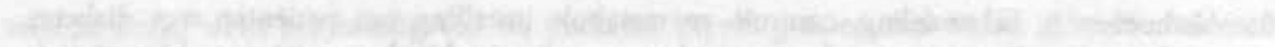

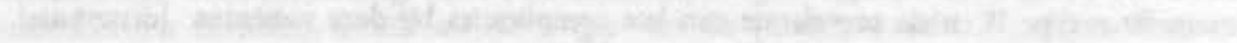

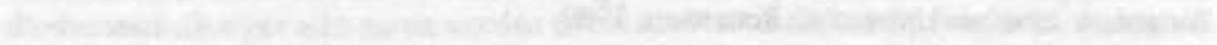

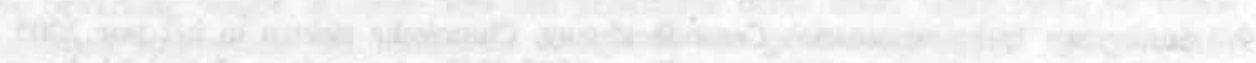

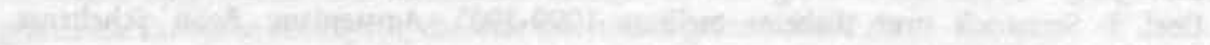

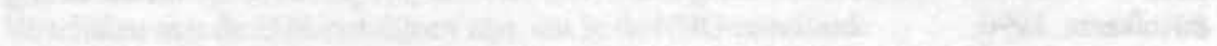

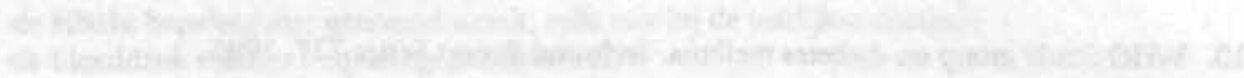

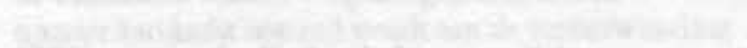

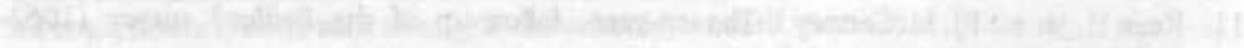

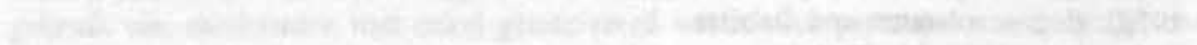

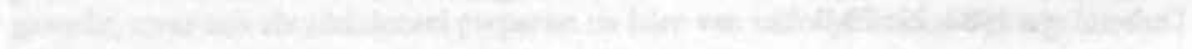

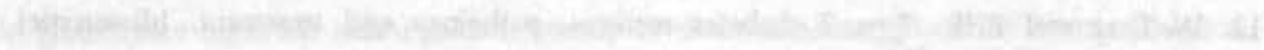

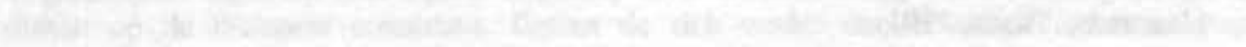

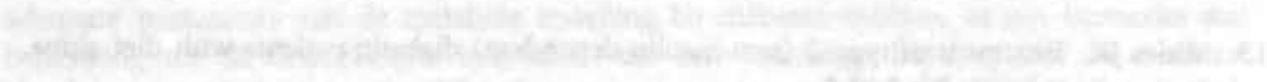

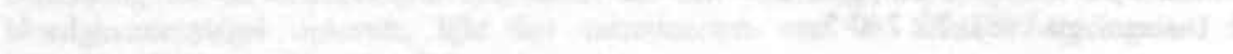

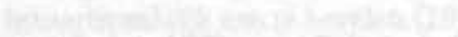

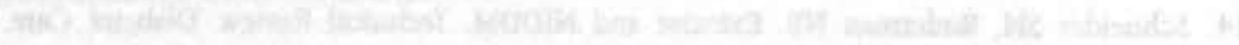

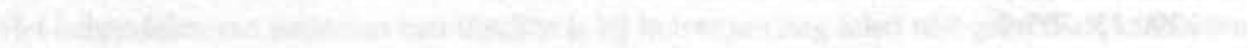

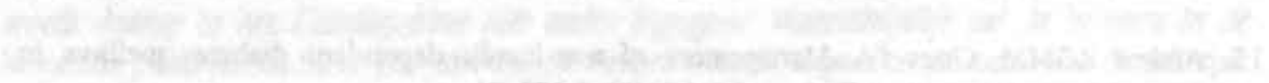

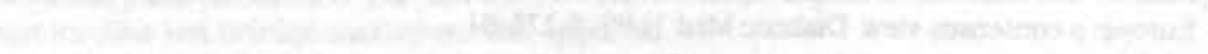

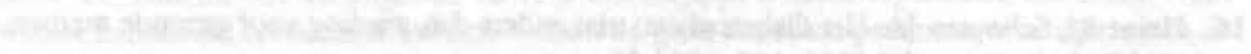

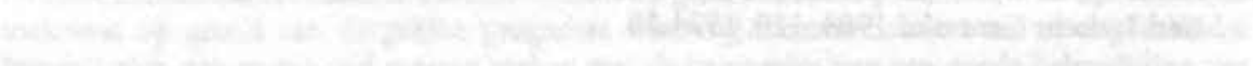

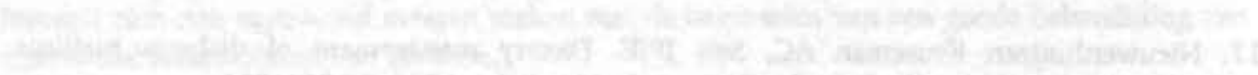

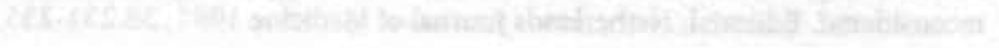

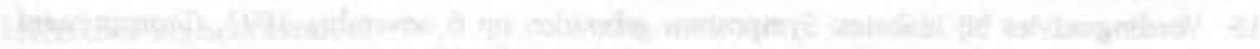

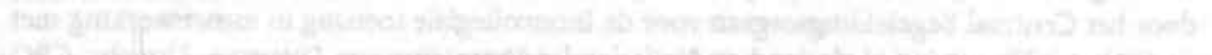

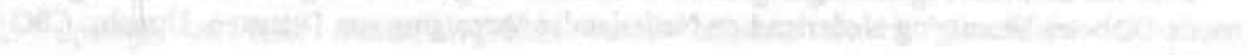

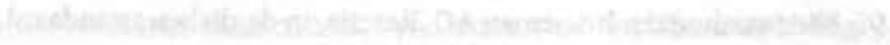

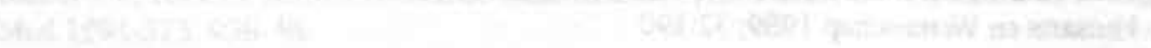

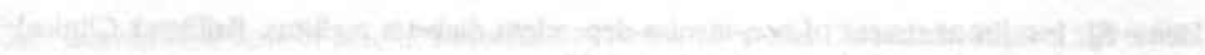
71.

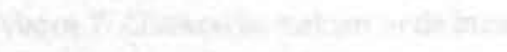




\section{Hoofdstuk 4}

\section{Toetsconstructie, validiteit en toetsvorm}

\subsection{Toetsconstructie}

\subsubsection{Algemene voonwaarden bij de keuze van de vraagvorm}

Als we het mondeling examen als toetsvorm buiten beschouwing laten, omdat deze arbeidsintensieve vorm van toetsen in dit geval niet in aanmerking komt, en ons beperken tot schriftelijk af te nemen toetsen, dan wordt meestal een onderscheid gemaakt tussen essayvragen en objectieve toetsvragen.

Bij essayvragen gaat het om niet voorgestructureerde antwoordmogelijkheden. De deelnemer aan een toets met essayvragen heeft als taak om in eigen woorden een antwoord te geven op de geformuleerde vragen. Nadelen van deze toetsvorm zijn:

- de beperking in het aantal onderwerpen dat per test aan bod kan komen

- de nadruk op schrijf- en formuleervaardigheid van de kandidaat

- de problemen bij het scoren.

Het blijkt moeilijk om de gegeven antwoorden op een vergelijkbare wijze - d.w.z. betrouwbaar te beoordelen. Bij het nakijken van een toets met essayvragen door verschillende beoordelaars blijken vaak grote verschillen tussen beoordelaars voor te komen. Deze interbeoordelaarsvariatie is gedeeltelijk terug te dringen door scoringsprotocollen op te stellen, waarin zo nauwkeurig mogelijk wordt aangegeven, wat als goed en wat als fout zal worden geteld. Een ander bezwaar is, dat het nakijken van essayvragen meestal tijdrovend is.

Bij de zogeheten objectieve toetsvormen zijn er allereerst de multiple choice toets, waarbij het goede antwoord gekozen moet worden uit een aantal alternatieven en de toets met juistonjuist vragen, waarbij per vraag een bewering moet worden beoordeeld. In beide gevallen spreek tmen van gesloten vraagvormen. De voordelen van de gesloten vraagvorm zijn:

- goede betrouwbaarheid

- geschiktheid voor geautomatiseerde verwerking.

De multiple choice vraag heeft als nadeel ten opzichite van de juist/onjuist vraag dat het construeren van hoogwaardige alternatieve antwoordmogelijkheden moeilijk is.

Metz (i) stelt in zijn uitvoerige bespreking van methoden voor de meting van medische competentie, dat de gesloten vraagvorm maar beperkt bruikbaar is om daarmee medische competentie te meten. Hij stelt dat eigenlijk alleen kennis goed te meten is met een dergeljjke vraagvorm. Hoewel medische competentie weliswaar een kennisdeel omvat, zijn toch factoren als gebruik maken van kennis (probleem oplossen), sociale vaardigheid, attitude en handvaardigheid eveneens van belang. Hij komt tot de conclusie dat kennis en medische competentie des te meer met elkaar te maken hebben, naarmate de kennis 'klinisch relevanter' is. Alleen bij gebruik van klinisch zeer relevante feiten ziet hij een plaats voor de gesloten vraagyorm in een toets.

Er worden echter hoge correlaties gevonden tussen de verschillende vraagvormen, zelfs tussen schriftelijke metingen en praktijkmetingen. Hieruit is af te leiden dat veeleer de stimulus van belang is (namelijk de taak die wordt voorgelegd) dan de response-vorm (bijvoorbeeld een open of een gesloten vraag). Van essentieel belang is de klinische rijkheid van een goede toets.

Ebel, een bekende Amerikaanse onderwijskundige, geeft de volgende argumenten aan voor het gebruik van de gesloten vraagvorm, in dit geval de juist/onjuist vraag:

The basic reason for using true-false items is that they provide a single and direct means of measuring the essential outcome of formal education. The argument for the value of true-false 
items as measures of educational achievement can be summarized in four statements:

1. The essence of educational achievernent is the command of useful verbal knowledge

2. All verbal knowledge can be expressed in propositions

3. A proposition is any sentence that can be said to be true or false

4. The extent of student's command of a particular area of knowledge is indicated by their success in judging the truth or falsity of propositions related to it

To test a person's command of an idea or element of knowledge is to test his or her understanding of it.

A student who can recognize an idea only when it is expressed in some particular set of words does not have command of it. Neither does the student who knows the idea only as an isolated fact, without seeing how it is related to other ideas.

Knowledge one has command of is not a miscellaneous collection of seperate elements but an integrated structure that one can use to make decisions, draw logical inferences, or solve problems. It is usable knowledge.(2)

In dit onderzoek is gekozen voor de juist/onjuist vraagvorm. De gebruikte diabetestoetsen bevatten vragen die voor het overgrote deel huisartsgeneeskundig klinisch relevant zijn. Daarom lijkt gebruik van de gesloten vraagvorm geen grote nadelen te hebben. De juist/onjuist vraag leent zich goed voor geautomatiseerde verwerking en is daarom geschikt voor landelijk af te nernen toetsen (3).

Een veel gehoord punt van kritiek op juist/onjuist vragen is de grotere invloed van raden op de uitslag, vergeleken met een multiple choice vraag, waarin vaak vier of vijf antwoordalternatieven worden gegeven. Dit is het zogenaamde "cueing" naar het juiste antwoord. Uit vergelijking tussen open en gesloten vraagvormen blijkt dat cueing vooral invloed heeft op de gemiddelde prestatie op een toets, maar niet of minder op de rangordening van de kandidaten. Toetsverlenging is een probaat middel om de invloed van een hoge raadkans bij het gebruik van juist/onjuist vragen tegen te gaan. Wanneer een toets met juist/onjuist vragen tweemaal zoveel vragen bevat als een. multiple choice toets met vierkeuze vragen is de invloed van raden op de uitslag nagenoeg hetzelfde. Raden met verstand van zaken beschouwt Ebel overigens als een valide indicatie voor het te meten kennisniveau.

De volgende vijf vormeriteria voor goede juist/onjuist vragen zijn ook ontleend aan Ebel:

1. It should test the examinee's knowledge of an important proposition, one that is likely to be significant and useful in coping with a variety of situations and problems. It should say something worth saying.

2. It should require understanding as well as memory. Simple recall of meaningless words, empty phrases, or sentences learned by rote should not be enough to permit a correct answer.

3. The intended correct answer (true or false) should be easy for the item writer to defend to the satisfaction of competent critics. The true statements should be true enough and the false statements false enough so that an expert would have no difficulty distinguishing between them. Any explanation or qualification needed to justify an unconditional answer should be included in the item.

4. On the other hand, the intended correct answer should be obvious only to those who have good command of the knowledge being tested. It should not be a matter of common knowledge. It should not be given away by an unintended clue. The wrong answer should be made attractive to those who lack the desired command.

5. The item should be expressed as simply, as concisely, and above all as clearly as is consistent with the preceding four requirements. It should be based on a single proposition. Common words should be given preference over technical terms. Sentences should be short and simple in structure. Essentially true statements should not be made false by simply inserting the word not. (2) 
Dousma en Horsten (4) en Van Hessen en Verwijnen (5) voegen hier nog aan toe, dat woorden als geen, alle, nooit, vaak, soms, eventueel, in het algemeen dienen te worden vermeden, omdat ze sterk uitnodigen tot het kiezen van een bepaald antwoord.

Daarnaast stellen ze dat vragen met een ontkenning minder geschikt zijn. Wil men toch een ontkennend geformuleerde vraag gebruiken, dan dient deze ontkenning extra gemarkeerdi te worden. Tenslotte raden zij af om kunstmatige vragen te construeren, waarin niet bestaande, gefingeerde begrippen worden gebruikt (b.v. de prevalentie van type III diabetes is $3 \%$ ).

\subsubsection{Toepassing van kennis bij het oplossen van medische problemen.}

Vanuit de cognitieve psychologie is er de laatste jaren nieuw licht gekomen op de manier waarop mensen kennis toepassen bij het oplossen van problemen. Schmidt et al.(6) beschrijven dit in een overzichtsartikel over probleemoplossen in het medisch domein.

Er worden vier verschillende niveaus van cognitief functioneren onderscheiden. Deze kunnen gezien worden als ordinaal opeenvolgende niveaus van expertise. Als eerste is er een laag. niveau, dat slechts bestaat uit een vage notie van kernbegrippen, zoals een leek die zou kunnen hebben. Bijvoorbeeld:

diabetes heeft te maken met een afwijking in de glucosestofwisseling. Het daarop volgende niveau wordt 'dispersed knowledge' genoemd. Hierbij bestaat er een uitgebreide feitenkennis zonder dat er sprake is van integratie hiervan. Gebruik van de losse feiten in een complexe redenering is niet mogelijk. Medische leerboeken presenteren kennis vaak op dit niveau.

Bijvoorbeeld: een hypoglycaemie bij een diabetespatiênt kan leiden tot een ernstige daling in het bewustziju.

Een hyperglycaemie kan leiden tot een vergelijkbaar effect.

Het onderscheid tussen beide toestanden, dat klinisch zeer belangrijk is, kan niet goed gemaakt worden, als men niet over meer kennis beschikt. 'Elaborated knowledge' is de benarning van het derde niveau. De anwezige kennis is nu in een structuur ingebed, waarbij de diverse bestanddelen actief aan elkaar gekoppeld kunnen worden. Ook contextuele kenmerken, zoals specifieke patiêntgegevens kunnen een plaats krijgen in het beredeneren van een gegeven probleemstelling. Bijvoorbeeld: Als een patiênt met een hypoglycaemisch coma niet snel reageert op toediening van glucagon, dan kan dit komen doordat het glycogeen depot in de lever uitgeput is, doordat de patiènt langere tijd niet gegeten heeft. Intraveneuze toediening van glucose is dan de enige manier om de hypoglycaemie te bestrijden. Het hoogste niveau van kennis is de 'compiled knowledge'. Dit is het niveau van de expert, de ervaren arts. De kennis is nu zo volledig geintegreerd met ervaring, dat bij het oplossen van een probleem de fase van redeneren wordt overgeslagen; bijna reflexmatig en met grote snelheid komt men tot de gezochte oplossing.

Er vindt als het ware een kortsluiting plaats tussen kennis en ervaring, waarin patroonherkenning een belangrijk gegeven is.

Ervaren artsen blijken op deze manier te werk te gaan.

Bijvoorbeeld: Bij een 64 jarige vrouw met sinds enkele jaren bekende type ll diabetes zonder overgewicht, die orale bloedsuikerverlagende medicatie gebruikt in de maximale dosering en langere tijd nuchtere bloedsuikerwaarden boven de $14 \mathrm{mmol} / \mathrm{L}$ heeft, kan ter verbetering van de regulatie het beste overgeschakeld worden op 20 eenheden NPH insuline (toe te dienen voor het slapen gaan). In dit voorbeeld wordt gebruik gemaakt van ondermeer:

- leeftijd en te verwachten levensduur,

- geslacht,

- afwezigheid van overgewicht,waardoor de kans op verbetering van de regulering van de diabetes door dieetmaatregelen gering is,

- het onderkennen van het mechanisme dat het effect van orale medicatie na een aantal jaren niet meer effectief is,

- de wetenschap, dat 20 eenheden insuline ongeveer de hoeveelheid is, die nodig is om de orale medicatie te vervangen. 
Voor de evaluatie van medische competentie is deze indeling waarschijnlijk zeer bruikbaar. Bij. het kiezen van een geschikte manier van toetsing van medische competentie is het onderkennen van het expertise niveau doorslaggevend in de keuze van het type toets.

Zo is niveau twee dispersed knowledge het best te meten met eenvoudige gesloten vragen.

Niveau drie, elaborated knowledge zou dan beter middels simulatie instrumenten of toetsen. waarin vrij gedetailleerde casuistiek gebruikt wordt, geévalueerd kunnen worden. Op het. hoogste niveau zou gebruik gemaakt kunnen worden van zeer gedetailleerde aan de praktijk: ontleende casuistiek, waarin allerlei afleidende gegevens gehandhaafd blijven, bv door de patient naar voren gebrachte bezwaren tegen de inhoudelijk meest voor de hand liggende aanpak.

De in dit onderzoek gebruikte toetsen zijn geconstrueerd met de intentie om met name niveau drie en vier te meten, te weten de in de huisartspraktijk benodigde kennis alsmede beheersing. van te volgen behandelstrategieen binnen de context van individuele casuistiek.

De casuistiek is voor het grootste deel uit de praktijk afkomstig en zoveel mogelijk 'gestoffeerd' met enkele achtergronden van de betrokken patienten. Ook de vragen zelf liggen vaak dicht bij vragen die op het spreekuur gesteld worden. Al met al zijn er dus theoretische aanwijzingen dat de gebruikte toetsen om kennis over diabetes in de huisartsopleiding te meten wel degelijk ook voor een deel medisch probleemoplossen meten.

\subsection{Constructie van de twee diabeteskennistoetsen}

Met het Kennispakket als vertrekpunt werden twee parallelle kennistoetsen samengesteld, toets 1 voor de beginmeting en toets 2 voor de eindmeting.

Om ook in de toets zo dicht mogelijk bij het huisartsgeneeskundig handelen aan te sluiten werd gekozen voor toetsvragen van het type juist/onjuist, steeds ingeleid door een zo veel mogelijk binnen de context van de huisartspraktijk gangbare situatieschets. De deelnemer kan dus kiezen voor het antwoord 'juist 'of voor het alternatief 'onjuist' of hij/zij kan een vraagteken aankruisen. Deze vragen zijn gegroepeerd rondom een casus. In 17 casus wordt steeds een patiènt aangeboden, die vaak voorkomende of belangrijke problemen presenteert, zoals die zich bij diabetespatiénten kunnen voordoen. Na de situatieschets worden enkele vragen gesteld over het door de huisarts-uit-de-casus gepresenteerde beleid. Op deze wijze is het mogelijk om een betrekkelijk groot aantal items aan de orde te stellen. Voorbeeld van cen casus en een vraag:

\section{Casus 5}

De heer Bakker, 56 jaar oud, komt op het diabetesspreekuur van zijn huisarts voor controle van zijn sinds een half jaar bestaande type Il diabetes mellitus. Zijn gewicht is nu $78 \mathrm{~kg}$ bij een lengte van $172 \mathrm{~cm}$. Met hulp van de diêtiste is hij vier kilo afgevallen in de loop van zes maanden. De bloedsuiker is nu $15 \mathrm{mmol} / \mathrm{L}$ (voorheen $17,14 \mathrm{en} 16 \mathrm{mmol} / \mathrm{L}$ ). De huisarts besluit om patiènt 1 tablet gliclazide (Diamicron @) 's ochtends voor te schrijven.

- vraag 29: In dit geval is het beter om een sulfonylureum preparaat uit de eerste generatie (zoals tolbutamide) voor te schrijven dan een tweede generatie preparaat zoals Diamicron@.

Antwoord: juist//onjuist

\subsubsection{Procedure constructie toets 1 en inhoud casulstiek}

Toets 1 telt 126 vragen, verdeeld over 17 casus met daarmaast 18 niet casusgebonden vragen. Per casus wordt steeds een diabetespatiènt beschreven, die een aantal problemen presenteent. Bij de keuze van de onderwerpen werd zoveel mogelijk uitgegaan van gevallen uit de praktijk 
van de auteurs en van de geraadpleegde internisten.

In overleg met de medeauteurs van de toets werd besloten om een aantal vaak voorkomende en een aantal minder vaak voorkomende, maar voor huisartsen cruciale, problematische situaties op te nemen. Gedacht moet worden aan zaken als: regulatie op hoge leeftijd, herkennen van hypoglycaemie, bepalen van het moment van verwijzing bij ontregeling, onderkennen van geneesmiddeleninteracties.

Daarnaast is zoveel mogelijk getracht gewone problemen hiertussen door te weven, zodat een afwisselend geheel ontstond. Door in de casusbeschrijving zo realistisch mogelijk aan te sluiten bij de gang van zaken in de huisartspraktijk is getrachı om het verschil tussen roets en opleidingssituatie zo klein mogelijk te maken. De volgende onderwerpen worden aan de orde gesteld, na uitvoerige consultatie met de groep betrokken deskundigen.

Casus 1 : Criteria voor de behandeling van een 82 -jarige man met licht verhoogde blnedsuiker

Casus 2 : Uitgebreid lichamelijk onderzoek bij type II diabetes

Casus 3 : Nierdrempel voor glucose en diureticagebruik bij type Il diabetes

Casus 4 : Zwangerschap en diabetes

Casus 5 : Medicatie bij type Il diabetes

Casus 6 : Latrogene diabetes en dieetproblematiek

Casus 7 : Beleid bij slechte compliance bij type II diabetes, dieet en verstrekkingen

Casus 8 : Complicaties bij type II diabetes en beleid

Casus 9 : Spoedvisite vanwege hypoglycaemie bij een type I diabetespatient

Casus $10:$ :Spoedvisite vanwege hypoglycaemie door geneesmiddelinteractie

Casus 11 : Gestoorde glucose tolerantie

Casus 12 : Type II diabetes mellitus op jonge leeftijd

Casus 13 : Complicaties en beleid bij een slecht ingestelde type II diabetespatiént

Casus 14 : Recidiverende urineweginfectie en diabetes

Casus 15 :Ontregeling door alcoholmisbruik bij type 1 diabetes

Casus 16 : Ontregeling bij type II diabetes

Casus 17 : Een 38-jarige type 1 diabetespatiênt met misselijkheid en braken

Eerst werd de casuistiek in ruwe vorm uitgeschreven aan de hand van een blauwdruk waarin alle belangrijke onderwerpen die volgens de auteurs aan de orde zouden moeten komen, vervolgens werd een aantal malen vergaderd over veranderingen en uitbreidingen. Het aantal casus en het aantal vragen zijn resultaat van dit proces.

$\mathrm{Na}$ constructie werden een tiental rubrieken samengesteld, waarin de vragen naar onderwerp konden worden ingedeeld.

Rubriek 1 bevat vragen, die over het handelen bij de acute ontregeling van type 1 diabetes inellitus patiênten gaan.

Rubriek 2 bevat vragen over niet acute situaties bij type I diabetes mellitus patiénten.

Rubriek 3 bevat vragen over erfelijkheid, epidemiologie en prognose van diabetes mellitus.

Rubriek 4 heeft als onderwerp de pathofysiologie van diabetes mellitus. Aangezien dit onderwerp vanuit de huisartsgeneeskundige optiek geen prioriteit had bij de toetsconstructie, zijn er weinig vragen in terecht gekomen.

Rubriek 5 heeft als onderwerp de diagnostiek van type Il diabetes mellitus.

Rubriek 6 gaat vooral over de diagnostiek van complicaties bij patiénten met type II diabetes mellitus en over ontregeling bij deze groep. Een overlap met complicaties, zoals die ook op kunnen treden bij type 1 patienten is hierbij niet te vermijden.

In rubriek 7 zijn vragen gegroepeerd over orale medicatie, overige therapie en beleid bij type II diabetespatiênten.

Rubriek 8 bevat vragen over dieetrichtlijnen. 
Rubriek 9 behandelt maatschappelijke aspecten van de aandoening. Met name psychosociale en financiêle onderwerpen hebben hier een plaats gekregen.

Rubriek 10 tenslotte wordt gevormd door vragen die niet in een van de bovenstaande rubrieken geplaatst konden worden.

De rubrieken volgen ongeveer de onderwerpen uit het Kennispakket.

Tabel 3 Verdeling vragen per casus over de rubrieken toets 1

\begin{tabular}{|c|c|c|c|c|c|c|c|c|c|c|c|}
\hline \multirow[b]{2}{*}{ Casus. } & \multicolumn{10}{|c|}{ Rubrick } & \multirow[b]{2}{*}{ tot. } \\
\hline & 1 & 2 & 3 & 4 & 5 & 6 & 7 & 8 & 9 & 10. & \\
\hline 1 & & & & & & & 4 & & & & 4 \\
\hline 2 & & & 1 & & & 10 & & & & & 11 \\
\hline 3 & & & & & 1 & & 1 & & & & 2 \\
\hline 4 & & & 5 & & 2 & & 1 & & & & 8 \\
\hline 5 & & & & & & 3 & 2 & & & & 5 \\
\hline 6 & & & & 1 & & 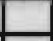 & 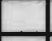 & 4 & & & 5 \\
\hline 7 & & & & & & 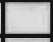 & 1 & & 5 & & 6 \\
\hline B & & & & & 1 & 5 & 6 & & & & 12 \\
\hline 2 & 13 & & & & & 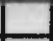 & & & & & 13 \\
\hline 10 & & & 1 & & & 4 & & & & & 5 \\
\hline 11 & & & 2 & & 1 & 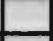 & & & & & 3 \\
\hline 12 & & & 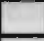 & & 5 & 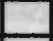 & 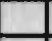 & & & & 5 \\
\hline 13 & & & & & & 8 & 1 & & & & 9 \\
\hline 14 & & & 1 & & 2 & & & & 1 & & 4 \\
\hline 15 & 3 & & & & & & & & 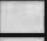 & & 3 \\
\hline 16 & & & & & & 6 & & 1 & & & 7 \\
\hline 17 & & 6 & & & te & & 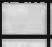 & - & - & & 6 \\
\hline $\begin{array}{l}\text { niet casus ge- } \\
\text { bonden vragen }\end{array}$ & & 1 & 2 & & & & 1 & 2 & 2 & 10 & 18 \\
\hline tot & 16 & 7 & 12 & 1 & 12 & 36 & 17 & 7 & 8 & 10 & 126 \\
\hline
\end{tabular}

Toets 1 is opgenomen in bijlage 1.

\subsubsection{Toets 2}

In de zomer van 1985 werd de tweede toets geconstrueerd naar analogie van de eerste toets. De casus bleven in dezelfde vorm gehandhaafd, met uitzondering van de eerste casus. Deze eerste casus werd veranderd omdat de formulering van de probleemstelling achteraf bezien niet goed was. Toets 2 telt in totaal 124 vragen, waarvan er 107 verdeeld zijn over 17 casus en 17 niet casusgebonden vragen. De onderwerpen, die in toets 2 aan de orde worden gesteld zijn dezelfde als bij toets 1, met uitzondering van casus 1 , die betrekking heeft op voetverzorging. Toets 2 is opgenomen in bijlage 2.

Bij vergelijking van bijlage 1 en 2 valt op dat de vragen uit toets 2 veel lijken op die uit toets 1 . Meestal werd volstaan met een kleine verandering in de strekking van de vraag. Soms werd de vraagstelling omgekeerd, bijvoorbeeld in plaats van naar symptomen van hypoglycaemie werd naar symptomen van hyperglycaemie gevraagd.

Tevens werd getracht om de verhouding van het aantal vragen met de antwoordsleutel "juist" versus "onjuist" in beide toetsen gelijk te houden. Uit onderzoek blijkt dat dit van belang is, omdat "onjuist" gesleutelde vragen vaker fout worden beantwoord dan "juist" gesleutelde vragen (7). Achteraf hebben we dit niet gerealiseerd: in toets 1 zijn er 70 vragen met de antwoordsleutel "juist" en 46 met de antwoordsleutel "onjuist"; in toets 2 zijn deze aantallen respectievelijk 62 en 47 . 
Ook het aantal vragen is niet gelijk per casus. De verdeling van de vragen uit de diverse rubrieken over de casus is eveneens niet helemaal identiek.

Omdat we veel meer gelnteresseerd waren in de rubriekscores is verder geen aandacht besteed aan casusscores. De verdeling van de vragen van toets 1 en 2 over de 10 rubrieken is weergegeven in tabel 4.

Tabel 4 Rubrieksindeling en aantal vragen in toets 1 en toets 2 per rubriek

\begin{tabular}{|c|c|c|l|}
\hline Rubriek & $\begin{array}{c}\text { Aant. vragen } \\
\text { toets } 1\end{array}$ & $\begin{array}{c}\text { Aant. vragen } \\
\text { toets } 2\end{array}$ & \multicolumn{1}{|c|}{ Onderwerp } \\
\hline 1 & 16 & 16 & Acute situaties bij type I diabetes \\
\hline 2 & 7 & 7 & Niet acute situaties bij type I diabetes \\
\hline 3 & 12 & 10 & Epidemiologie, erfelijkheid en prognose \\
\hline 4 & 1 & 3 & Pathofysiologie \\
\hline 5 & 12 & 12 & Diagnostiek van diabetes mellitus \\
\hline 6 & 36 & 32 & Diagnostiek van complicaties en ontregeling \\
\hline 7 & 17 & 20 & Medicatie, overige therapie en beleid \\
\hline 8 & 7 & 8 & Dieet bij diabetes mellitus \\
\hline 9 & 8 & 9 & Psychosociale en financiele aspecten van diabetes mellitus \\
\hline 10 & 10 & 7 & Diverse, niet in te delen vragen \\
\hline totaal & 126 & 124 & \\
\hline
\end{tabular}

Uit tabel 4 blijkt dat het aantal vragen per rubriek in beide toetsen ongeveer even groot is. De rubrieken 3 tot en met 9 bevatten vragen over type II diabetes. Uit de verdeling van de vragen over de 10 rubrieken komt duidelijk tot uiting dat een expliciet accent werd gelegd op kennis over behandeling en begeleiding van de type II diabetespatiênt. Van de 126 vragen van toets 1 hebben 93 vragen hoofdzakelijk betrekking op type II diabetes, tegen 23 vragen die over type I diabetes gaan. Bij toets 2 hebben 94 vragen betrekking op type II diabetes, versus 23 vragen die over type 1 diabetes gaan. Rubriek 10 'diversen' bevat 10 vragen in toets 1 en 7 vragen in toets 2.

De keuze voor deze accentuering is ontieend aan de reeds eerder geciteerde rapporten LHVBasistakenpakket van de huisarts en Kenmerken van de huisarts II, waarin de zorg voor de oudere, niet insuline afhankelijke diabetespatiênt expliciet tot de taak van de Nederiandse huisarts wordt gerekend. De zorg voor de insuline afhankelijke diabetespatiênten wordt slechts voor een klein deel en dan meer in de begeleidende sfeer als taak voor de huisarts gezien, naast de eerste opvang bij acute pntregeling. Zoals in hoofdstuk 3 reeds werd opgemerkt met betrekking tot het Kennispakket, komt ook in de toetsvragen de behandeling met insuline bij type II diabetes niet uitgebreid aan de orde.

De antwoordsleutel van de twee toetsen, die respectievelijk 126 en 124 vragen bevatten, werd ter controle voorgelegd aan twee iriternist-endocrinologen.

De tweede diabetestoets mag worden gezien als een variant van de eerste toets. De casulstiek is in grote lijnen identiek gebleven, alleen de vragen werden enigszins omgewerkt. Op deze manier werd bereikt dat de scores op de casus uit toets 1 in de meeste gevallen vrij goed te vergelijken zijn met die van toets 2 , zij het dat het aantal vragen per casus in toets 1 en toets 2 niet altijd even groot is. Voor deze werkwijze is mede gekozen, omdat het moeilijk bleek nog eens 17 volledig nieuwe casus samen te stellen zodanig dat voldoende inhoudelijke parallelliteit 
gewaarborgd kon worden. In tabel 5 wordt de verdeling van de vragen per rubriek over de casus van toets 2 gegeven.

Tabel 5 Verdeling vragen per casus over de rubrieken toets 2

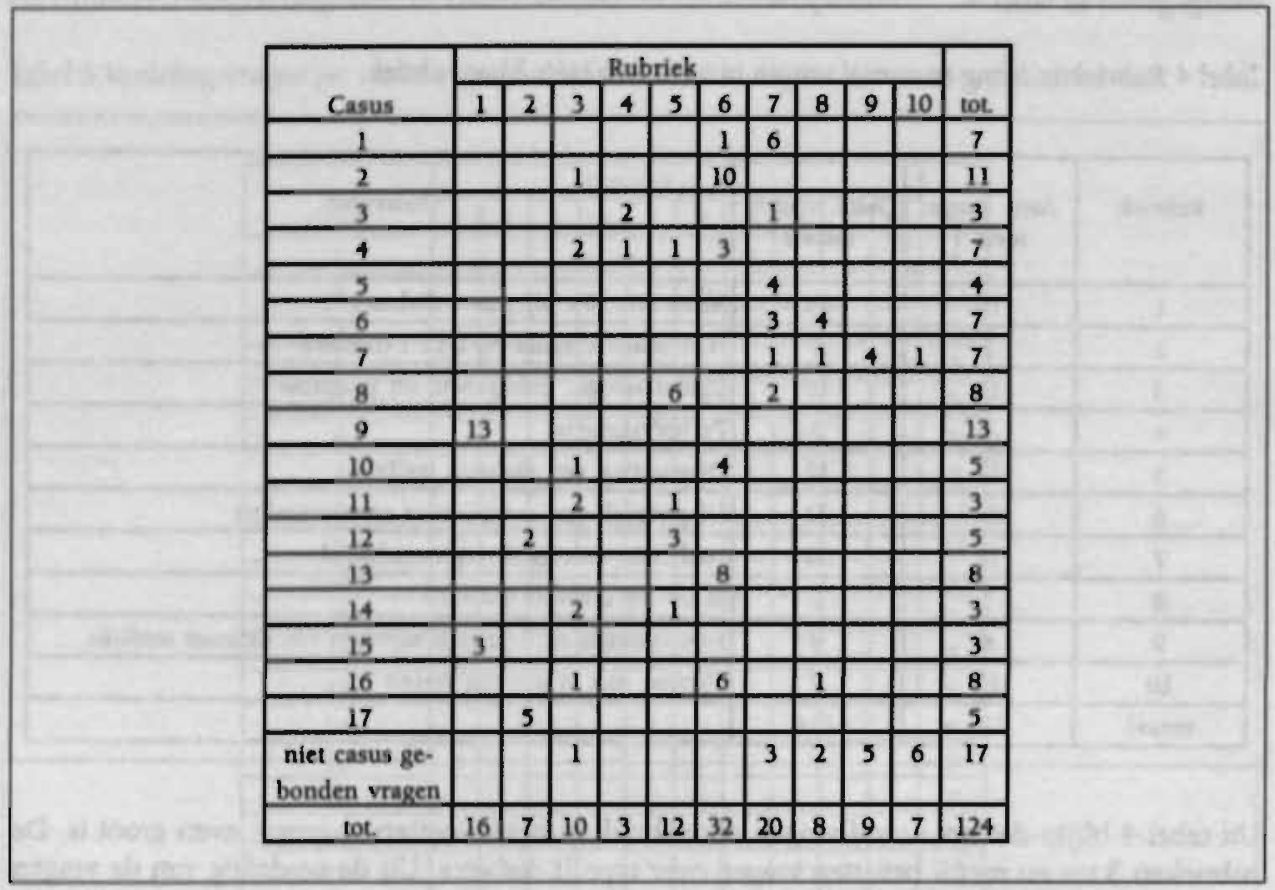

Na afname van de toetsen bij de 219 deelnemers aan toets 1 en de 191 deelnemers aan toets 2 werd het commentaar dat door enkele tientallen deelnemers in de vorm van schriftelijke opmerkingen was aangeleverd, nauwkeurig bekeken. Ook commentaar dat mondeling werd verstrekt door de opleidingsgroep tijdens nabespreking van de toets met de onderzoeker - dit is in enkele groepen gebeurd - werd vastgelegd en besproken met de begeleidingsgroep.

Op grond van hetgeen door de begeleidingsgroep als relevante kritiek werd aanvaard werd besloten tot verwijdering van een vraag. Na verwerking van de vragen werd een itemanalyse verricht. Per item werden de moeilijkheidsgraad of $\mathrm{p}$-waarden bekeken. De $\mathrm{p}$-waarde is de proportie proefpersonen die een juist antwoord heeft gegeven op een toetsvraag. De mogelijke: waarde van $\mathrm{p}$ lige tussen 0 en 1.

Verder werd de itemtotaalcorrelatie berekend (RIT) voor iedere vraag. Deze coéfficiènt geeft de mate weer waarin elk item afzonderlijk samenhangt met (hetzelfde meet als) de hele test. Bij de itemtotaalcorrelatie is de maximale waarde van de coefficiênt $\mathbf{l}$.

Vragen met cen duidelijk afwijkende itemtotaalcorrelatie (RII) werden nog eens nauwkeurig bekeken. Aan het commentaar van de deelnemers werd meer waarde toegekend, dan aan de waarde van de itemparameters.

In Hoofdstuk 5 en Hoofdstuk 7 wordt vermeld welke items uit de toetsen verwijderd werden en met welke reden. Na verwijdering van de afgekeurde vragen werden over de resterende vragen de scores berekend in percentage goed en percentage fout beantwoorde vragen. 
Bij de berekening van de toetsresultaten wordt alleen een punt toegekend, wanneer gekozen is voor het goede antwoord. Is gekozen voor het vraagteken of voor het onjuiste antwoord dan wordt geen punt toegekend. Elk goed antwoord levert dus 1 punt op. Foute antwoorden worden niet in de score verdisconteerd.

In de Maastrichtse Voortgangstoets (MVT), een uit ongeveer 250 vragen van het type juist/onjuist bestaande toets die vier maal per jaar afgenomen wordt bij alle studenten van de medische faculteit in Maastricht, wordt een ander systeem van waardering gehanteerd. Hierbij wordt elk fout antwoord bestraft met een minpunt, voornamelijk om het raden niet aan te moedigen. Daar komt nog bij dat de Maastrichtse Voortgangstoets in principe betrekking heefi op de gehele spleiding, terwijl de toets wordt afgenomen bij alle studentern, ook de studenten in de eerste studiejaren. Het is niet zinvol om in dit geval raden an te moedigen. Het is echter gebleken, dat de betrouwbaarheid van de 'goed min fout 'scores (percentage goed beantwoorde vragen min het percentage fout beantwoorde vragen) lager is dan die van de 'goed' scores. Van der Vleuten (8) beargumenteert dit door theoretisch uit te gaan van een hogere kennis bij een student die een fout antwoord aankruist dan bij degene die een vraagteken kiest. Dit betekent dat een fout antwoord testtheoretisch gezien eigenlijk van meer waarde is dan een vraagteken.

Bij het berekenen van de betrouwbaarheid wordt hier geen rekening rnee gehouden. In rekenexperimenten toont Van der Vleuten aan dat het probleem opgelost wordt bij een andere waardering van het foute antwoord, namelijk een waardering die ligt tussen die van een goed antwoord en die van een vraagteken.

In de Maastrichtse Voortgangstoets wordt het eventuele probleem van de verschillen in betrouwbaarheid afgezwakt. door het grote aantal vragen per toets (ongeveer 250). In een veel kortere toets zoals dc diabetestoets die ongeveer de helft van de lengte van de MVT heeft speelt dit probleem wel. Daarom is in dit onderzoek gekozen voor het gebruik van de 'goed' score (percentage goed beantwoorde vragen). Dit is te rechtvaardigen als de deelnemersi in de veronderstelling zijn dat een uiteindelijk resultaat op de toets bepaald wordt door de goed-fout score en gokken wordt ontmoedigd.

\subsection{Validiteit}

Bij het afnemen van kennistoetsen doet zich altijd de vraag voor naar de validiteit van hetgeen gemeten wordt. Meet de toets wel echt wat de constructeur van de toets wilde meten?

Blj de diabetestoets is het de bedoeling om kennis te meten bij huisartsen (in opleiding). Het gaat daarbij om kennis, die nodig is voor helt oplossen van regelmatig voorkomende problemen in de behandeling van ưiabetespatiênten in de huisartspraktijk.

Stel dat iemand wil weten wat de lengte van een proefpersoon is. Er staan hem dan verschillende wegen open om hierachter te komen. Meest voor de hand liggend is het gebruiken van een meetlat of centimeter om de lengte te bepalen. Gesteld kan worden, dat voor het opmeten van de lengte van een proefpersoon de centimeter een geschikte meetmethode is. Dit is in essentie waar het om gaat bij het begrip validiteit.

Wanneer iemand met een weegschaal het gewicht van de proefpersoon zou opnemen om daarmee de lichaamslengte vast te stellen, dan is dit eer niet valide meetmethode, omdat het. meetinstrument iets anders dan lengte meet, hoewel enige samenhang met de werkelijke lichaamslengte waarschijnlijk toch well te vinden is. In dit onderzoek worden, de beide kennistoetsen regelmatig als meetinstrument of test aangeduid.

De prestatie van de proefpersoon, uitgedrukt in het percentage correct beantwoorde vragen uit de toets wordt aangegeven met de woorden score, resultaat of kennisniveau.

Drenth $(9)$ onderscheidt allereerst predictieve validiteit en begripsvaliditeit.

Bij predictieve validiteit gaat het om de voorspelling van gedrag of een prestatie die buiten de 
testsituatie liggen. Er wordt een uitspraak gedaan over feiten waarover we geen directe evidentie hebben, maar waarover we een conclusie formuleren op grond van de kennis van andere - volgens onze veronderstellingen met die feiten samenhangende - gegevens. Die feiten kunnen in de toekomst liggen (Jantje zal een diploma van school A halen) of in het. heden (onderzochte lijdt aan een endogene depressie, ....).

Bij begripsvaliditeit gaat het bij het testen juist wel om het theoretische begrip zelf, waarmee men een verklaring kan geven van het testgedrag. De vraag naar de eigenschap, de karaktertrek of de persoonlijkheidseigenschap die verantwoordelijk geacht mag worden voor de testscore of het testresultaat is hier wel primair. Voor een zinvol beantwoorden van deze vraag zal men hierbij gebruik moeten maken van hypothetische (tegenover: empirische) begrippen. Het doel bij deze tweede soort testonderzoek is dus in eerste instantie de meting van die begrippen.

\section{Verder noemt Drenth:}

- predictive validity

Van deze validiteit wordt een schatting verkregen door na te gaan in welke mate de voorspellingen, gedaan op grond van de testprestatie, worden bevestigd door de evidentie die men verzamelt op een later tijdstip. Het verschil met de eerder genoemde predictieve validiteit ligt iñ de relatie naar de toekomst. Predictieve validiteit is eerder methodologisch op te vatten dan temporee! voorspellend. Hierdoor is dit begrip breder van omvang;

- content validity of inhoudsvaliditeit

Hiervan wordt een schatting verkregen door te beoordelen hoezeer de inhoud van de test een bepaald universum situaties, kennisinhouden of vaardigheden representeert waarover met betrekking tot de onderzochte conclusies moeten worden getrokken. Het is een begrip vooral van toepassing op het terrein van het onderwijskundig meten, waarbij geen conclusies worden getrokken over achterliggende processen, maar over het universum van taken waarvan de test een steekproef vormt. Bijvoorbeeld: In hoeverre mag men uit een proefwerk Franse grammatica iets concluderen over de kennis van de gehele Franse grammatica;

- concurrent validity

Deze vorm van validiteit wordt beoordeeld door na te gaan hoezeer resultaten corresponderen met gelijktijdig beschikbare criteriumgegevens. Voorbeeld: het valideren van een test door de testresultaten van patiênten te vergelijken met aanpassingsbeoordelingen van behandelende psychiaters;

- construct validity

Construct validity wordt geêvalueerd door te onderzoeken welke psychologische kwaliteiten een test meet. "Construct" is dan een of ander gepostuleerd attribuut, waarvan men veronderstelt dat het gereflecteerd wordt in de testprestatie.

\subsection{Validiteitsaspecten in dit onderzoek}

In deze paragraaf gaan we verder in op de construct validity en de inhoudsvaliditeit.

Construct validity is alleen maar goed te onderzoeken als het construct * in ons geval diabetesbehandeling in de praktijk - eenduidig te meten is. Hierbij kan dan gedacht worden aan productmetingen, b.v. de kwaliteit van de geleverde zorg aan de patiênt, patiêntsatisfactie of het optreden van complicaties. Men zou zich ook kunnen afvragen of de gezondheidstoestand van de patiênt toeneemt door de zorg van de behandelend huisarts?

Hoewel de consensus over taakafbakening in de diabetesbehandeling tussen huisarts en inter- 
nist langzaam maar zeker op gang komt is er op dit moment tussen huisartsen en internisten nog geen overeenstemming over welke elementen het meest wezenlijk zijn bij het succesvol behandelen van type II diabetespatienten. Internisten zullen waarschijnlijk metabole status van een patiênt belangrijker vinden dan huisartsen, die mogelijk satisfactie zwaarder laten wegen. Hierdoor is een onderzoeksmatige onderbouwing van de construct validity - door het relateren van opbrengst (in de zin van gezondheidsverbetering) aan kennisniveau (verkregen door meting met een diabetes-kennistoets) - een nog niet bereikbaar ideaal.

Inhoudsvaliditeit (content validity) beschrijft de mate waarin de toets een adequate steekproef vormt van het universum van het bedoelde kennisdomein, in ons geval mogelijke vragen op het terrein van de diabetesbehandeling, opgedeeld in belangrijke subgebieden. Hiertoe dient er volgens Thorndike (10) een duidelijke, gedetailleerde omschrijving te zijn van het kennisdomein dat wordt onderzocht. Tevens moet bekend zijn welke toepassingsvormen van de kennis worden gemeten en hoe de proefpersonen zijn geinstrueerd. Op basis hiervan kunnen experts de inhoudsvaliditeit van het kennisdomein beoordelen.

In ons onderzoek werd bij het opstellen van het Kennispakket een zo concreet mogelijke inhoudelijke beschrijving van het kennisdomein gemaakt. Hierbij werd uiteraard uitgegaan van allerlei impliciete veronderstellingen. Zo werd de setting van de huisartspraktijk bekend verondersteld. Ook werd uitgegaan van een hoeveelheid voorkennis op het gebied van diabetes mellitus en de geneeskunde in het algemeen, zoals die bij een arts, die de medische basisopleiding achter de rug heeft, verondersteld mag worden.

Door in de toets nauw aan te sluiten bij situaties, zoals die worden gepresenteend in de spreekkamer en door aan te sluiten bij de leersituatie van de huisarts-in-opleiding werd geprobeerd een zo goed mogelijke aansluiting tussen toets en realiteit te verkrijgen.

In de opleidingssituatie wordt door de huisarts-in-opleiding bij de behandeling van chronische problematiek, zoals diabetes, bijna altijd voortgeborduurd op reeds eerder gegeven adviezen en behandelingen van de opleider. Dit maakt steeds een beoordeling van de behandeling van de betrokken patient tot dan toe nodig. Dit aspect is in de toets ingebouwd door een huisarts te beschrijven die een bepaald beleid uitstippelt. De huisarts-in-opleiding wordt steeds gevraagd dit beleid op juistheid te beoordelen.

Op basis van het Kennispakket en de beide toetsen is aan het panel van huisartsexperts gevraagd on de inhoudsvaliditeit van de toetsen te beoordelen. Het panel kreeg de beide toetsen en het Kennispakket samen voorgelegd met de volgende drie vragen:

1. Zijn de casuistiek en de opgenomen toetsvragen relevant voor de eerstelijnszorgverlening aan diabetespatiênten?

2. Vormen de beide toetsen een goede inhoudelijke representatie van het kennispakket?

3. Vindt u de toetsen geschikt om kennis over diabetes te toetsen bij huisartsen?

In tabel 6 staan de reacties weergegeven. 
Tabel 6 Expert oordeel over relevantie en representativiteit van de diabetestoetsen

\begin{tabular}{|c|c|c|c|l|}
\hline Expert & $\begin{array}{c}\text { Toets } \\
\text { relevant }\end{array}$ & $\begin{array}{c}\text { Aanshuiting } \\
\text { toetsen- } \\
\text { pakket }\end{array}$ & $\begin{array}{c}\text { Toets geschikt } \\
\text { voor kennismeting } \\
\text { bij huisartsen }\end{array}$ & \\
\hline 1 & $?$ & $?$ & $?$ & veel lof, 10 opmerkingen bij tekst pakket \\
\hline 2 & + & + & + & randvoorwaarden bij behandeling van diabetes belangrijk \\
\hline 3 & + & $?$ & + & felicitaties, 10 opmerkingen bij tekst pakket \\
\hline 4 & + & + & + & enkele opmerkingen bijtoetsen en pakket \\
\hline 5 & + & + & + & enkele opmerkingen bij pakket, enkele kritische kanttekeningen \\
\hline 6 & + & + & + & spreiding van de vragen over rubrieken van toets onevenwichtig \\
\hline & & & & Enkele casus minder relevant \\
\hline
\end{tabular}

\section{+: mee eens ?: niet beantwoord}

Expert nummer 1 ging in zijn reactie niet expliciet op de gestelde vragen in. Expert nummer 3 gaf geen antwoord op de tweede vraag.

De experts die de vragen beantwoordden waren unaniem van mening,

- dat de toetsen relevant waren voor de eerstelijnszorgverlening aan diabetespatiênten,

- dat de aansluiting tussen Kennispakket en beide toetsen goed was en

- dat de toetsen geschikt waren om kennis over diabetesbehandeling bij huisartsen te meten.

Hiermee is de inhoudsvaliditeit van de in dit onderzoek gebruikte kennistoetsen redelijk gewaarborgd.

\subsection{Betrouwbaarheid}

Van een betrouwbare meting kan worden gesproken indien een herhaalde meting bij hetzelfde object, door verschillende waarnemers tegelijkertijd of door dezelfde waarnemer op verschillende tijdstippen of onder verschillende afnamecondities of met andere items uit hetzelfde domein steeds ongeveer dezelfde uitslag oplevert.

Hoe wordt betrouwbaarheid bepaald?

Als simpel voorbeeld kan opnieuw het meten van iemands lengte met een zorgvuldig gemaakte meetlat worden genomen. De uitslag van de test - te weten de lichaamslengte in centimeters dient steeds hetzelfde te zijn, wie de meting ook uitvoert. Hierbij wordt dan aangenomen dat de werkelijke lichaamslengte constant blijft.

Dit aspect van betrouwbaarheid van metingen wordt interbeoordelaarsbetrouwbaarheid genoemd. In dit onderzoek speelt interbeoordelaarsbetrouwbaarheid geen rol omdat gebruik wordt gemaakt van vragen, waarbij het correcte antwoord vooraf vastgesteld is, waardoor het vaststellen van het behaalde resultaat geautomatiseerd kan gebeuren. $\mathrm{Er}$ is dus geen sprake van variatie in oordelen op grond van verschillen tussen beoordelaars.

Daarnaast mag het, in het ideale geval, niet uitmaken voor het resultaat als de meting na verloop van tijd wordt herhaald. Evenmin mogen de omstandigheden of de plaats van meting er toe doen. Met de meetlat dient dus op allerlei plaatsen en tijden onder allerlei omstandigheden steeds dezelfde lengte te worden gemeten bij een bepaalde proefpersoon. Verschillen in gemeten lengte tussen rwee proefpersonen dienen te berusten op echte verschillen in lengte (ware variantie) en niet op allerlei mogelijke meetfouten (error variantie). Denk bijvoorbeeld aan afleesfouten of krimpen of uitzetten van de meetlat.

Een betrouwbaar meetinstrument in de testtheorie blijft met andere woorden stabiele meet- 
resultaten opleveren onder wisselende afnamecondities. Fluctuaties in de resultaten onder invloed van toeval of andere foutenbronnen mogen zich niet voor doen. Het instrument levert slechts geringe meetfouten en vertoont een acceptabele mate van consistentie.

Drenth (9) geeft een indeling van factoren, die van invloed zijn op de testvariantie en daarmee op de betrouwbaarheid. Hij onderscheidt achtereenvolgens wel en niet situatieve factoren en wel en niet specifieke factoren en factoren die al dan niet aan proefpersonen gebonden zijn.

In het algemeen kunnen we twee hoofdwegen tot het inschatten van de betrouwbaarheid onderscheiden: ten eerste de weg van een herhaald testonderzoek en ten tweede een bepaalde bewerking van eten enkel testonderzoek.

Binnen dat herhaald testonderzoek bestaan weer twee mogelijkheden: in de eerste plaats maakt men bij de tweede maal testen gebruik van een andere test die dezelfde "ware variantie" zou hebben als de test gebruikt voor het eerste onderzoek. Dit is de parallelvormmethode en leidt tot wat we willen noemen de a-specificiteitscoefficiênt.

Een speciale test van deze parallelvorm-methode is die waarbij dezelfde test tweemaal wordt afgenomen. Dit wordt genoemd de test-hertest methode. Omdat dit leidt tot een antwoord op de vraag hoe stabiel datgene is wat gemeten wordt, willen we de coefficiênt die het resultaat is van dit hertest-onderzoek in navolging van de Amerikaanse literatuur stabiliteitscoefficiênt noemen.

Ook binnen de methode van een bewerking van de testresultaten uit eén enkel onderzoek bestaan er weer verschillende mogelijkheden. De bekendste zijn wel de volgende twee variaties: ten eerste die, waarbij men de totale groep opgaven in twee gelijke helften splitst, waaruit de afzonderlijke scores berekend worden. De correlatie tussen deze scores geeft een schatting van de betrouwbaarheid. Dit is de zogeheten splitsingsmethode, waarbij een zo genoemde coêfficięnt van interne consistentie wordt verkregen.

Fen tweede methode van bepaling van deze interne consistentie is gebaseerd op een variantie-analyse van de antwoorden op de items en gaat uit van de interrelatie tussen de testitems afzonderlijk. Deze methode van itemanalyse leidt tot een variant van de vorige coéfficiênt, namelijk de coêfficiênt van item-consistentie of homogeniteitscoefficiènt.

In het schema zijnn de verschillende coêfficiênten nog eens overzichtelijk gepresenteerd.

$\begin{array}{lll}\text { Herhaalde meting } & * & \begin{array}{l}\text { paralleltest (a-specificiteit) } \\ \text { dezelfde test (stabiliteit) }\end{array} \\ \text { Eénmalige meting } & * & 2 \text { helften (interne consistentie) } \\ \text { items (homogeniteit). }\end{array}$

\subsection{Betrouwbaarheidsmeting in dit onderzoek}

In dir onderzoek is gebruik gemaakt van de itemanalyse en van de afname van parallelle tests.

\subsubsection{Parallelvorm-methode}

Bij de parallelvorm-methode voor de schatting van de betrouwbaarheid moet een schatting worden verkregen van de proportie ware variantie in een test. Drenth (9) zegt over de parallelvorm-methode het volgende:

Als we nu een tweede test zouden hebben die dezelfde ware variantie heeft als de oorspronkelijke en waarvan de scores alleen van die van de oorspronkelijke afwijken door het stuk toevalsvariantie dat in beide tests voorkomt, dan is aan te tonen dat de correlatie tussen beide tests een schatting van de betrouwbaarheid geeft. 
Twee tests zijn dus paralleltests als:

1. zij dezelfde standaarddeviatie hebben;

2. zij gelijke correlaties vertonen met een reeks ware scores

3. de variantie die niet wordt gedetermineerd door de ware scores is op te vatten als toevalsvariantie.

Voor een beschrijving van de manier waarop in dit onderzoek de afname van parallelle tests is verricht wordt verwezen naar hoofdstuk 8 .

\subsubsection{Itemanalyse}

Over de itemanalyse zegt Drenth (9):

Uit de gemiddelde correlatie tussen de items en het aantal items zou de betrouwbaarheid van een test berekend kunnen worden. De hierbij ontwikkelde coéfficiênt, de coêfficiênt van itemconsistentie, geeft aan in hoeverre van item tot item precies hetzelfde wordt gemeten. Meten items alle dezelfde factor(en) op gelijke wijze, dan zullen de interrelaties tussen die items hoog zijn. Meten ze daarentegen verschillende factoren (of toeval), dan zal die coefficiênt laag zijn.

In feite is dus deze coefficiènt van itemconsistentie te typeren als een indicatie van de homogeniteit van de test, reden waarom deze coéfficiênt dan ook wel genoemd wordt de homogeniteitscoêfficiênt.

De Cronbach' alpha is in dit onderzoek als maat van interne consistentic berekend. (De maximale waarde hiervan bedraagt 1). De Cronbach's alpha is sterk afhankelijk van de testlengte. Bij de interpretatie van een bepaalde alpha dient altijd met de testlengte rekening gehouden te worden.

\section{Literatuur bij hoofdstuk 4}

1. Metz JCM. Medische competentie, een onderzoek naar de betrouwbaarheid en de validiteit van het gestructureerd klinisch examen. [dissertatie] Nijmegen: 1984.

2. Ebel RL. Essentials of educational measurement. Englewood Cliffs NJ: Prentice Hall, 1979.

3. Wijnen WHFW. Ja-nee vragen, een toetsprocedure met mogelijkheden. Onderzoek van onderwijs 1973; 2: 12-14.

4. Dousma T. Horsten A. Tentamineren. Utrecht: Het Spectrum, 1980.

5. Hessen PAW van, Verwijnen GH. De constructie yan juist/onjuist vragen. Maastricht: PES Medische Faculteit Rijksuniversiteit Limburg,1988.

6. Schmidt HG, Norman GR, Boshuizen HPA. A cognitive perspective on medical expertise: theory and implications. Academic Medicine 1990 vol 65;10:611-21.

7. Verwijnen GM, Imbos $T$, Van Hessen PAW, Wijnen WHFW. What's in the score. An exploratory Analysis of true/false test scores. PES publicaties no. 160. Maastricht: Rijksuniversiteit Limburg, 1987.

8. Van der Vleuten CPM. Goed en fout van de goed min fout score. PES Publicaties, Maastricht: 1988. 
9. Drenth PJD. Inleiding in de testtheorie. Deventer: Van Loghum Slaterus, 1977.

10. Thorndike RL. Applied Psychometrics. Boston: Houghton Mifflin Company, 1982. 



\section{Hoofdstuk 5}

\section{Afname toets 1 bij huisartsen-in-opleiding}

\subsection{De deelnemers}

In de periode van mei tot december 1985 werd toets 1 afgenomen bij 219 artsen die kort tevoren met de beroepsopleiding tot huisarts waren begonnen.

Alle acht Nederlandse huisartsinstituten waren behulpzaam bij het leveren van twee of drie opleidingsgroepen van 10-12 personen. In verband met de sterk uiteenlopende startata per opleidingsinstituut werd bepaald dat opleidingsgroepen die nul tot maximaal 2,5 maand in opleiding waren tot de 'beginners' werden gerekend. Hierdoor was het mogelijk om de toetsafname met het oog op de noodzakelijke geheimhouding van de toetsvragen, op ongeveer hetzelfde tijdstip te laten plaatsvinden bij de verschillende instituten.

De deelnemende groepen zijn niet a-select gekozen, omdat de onderzoekers niet de mogelijkheid hadden om blind te kiezen uit een aantal groepen per instituut. De onderzoekers hadden geen invloed op de selectie van de groepen die aangeboden werden vanuit de instituten. De deelnemers aan de beginmeting begonnen tussen half februari 1985 en eind oktober 1985 met hun opleidingsjaar. Voorselectie voor deelname aan de toets vanuit de instituten is niet waarschijnlijk. De verdeling van de huisartsen-in-opleiding over de groepen vindt over het algemeen lang van te voren plaats. Er zijn dus redenen om aan te nemen dat de onderzochte groep als representatief kan worden beschouwd voor de totale groep artsen in opleiding tot huisarts (destijds jaarlijks zo'n 400 personen).

De toetsen werden zoveel mogelijk onder examencondities op het instituut afgenomen tijdens eerı terugkomdag. Er werd steeds een maximale invultijd van 1 uur aangehouden. De antwoordformulieren werden direct na het. maken van de toets ingeleverd bij de groepsbegeleider en naar de onderzoeker opgestuurd.

\subsection{Deelnemerskenmerken}

De 219 huisartsen-in-opleiding, die deelnamen aan toets 1 waren afkomstig van de acht beroepsopleidingen, zoals die in ons land worden verzorgd door de universitaire instituten voor. huisartsgeneeskunde.

De verdeling van de deelnemers naar instituut is weergegeven in tabel 7.

Tabel 7 Aantal deelnemers can toets 1 per instituut

\begin{tabular}{llllllllll}
\hline Instituten & 1 & 2 & 3 & 4 & 5 & 6 & 7 & 8 & totaal \\
H.a. in opl. n= & 35 & 32 & 24 & 19 & 36 & 35 & 18 & 20 & 219 \\
\hline
\end{tabular}

Om zicht te krijgen op de achtergronden van de deelnemers, kreeg elke huisarts-in-opleiding een korte, gestructureerde, vragenlijst voorgelegd. Hiermee werd informatie verzameld over de volgende onderwerpen:

- leeftijd

- geslacht

- jaar van afstuderen

- plaats van afstuderen

- werkervaring in de gezondheidszorg 
- hoeveelheid tijd besteed aan literatuurstudie over diabetes

- hoeveelheid tijd besteed aan formele nascholing over diabetes

- specifieke interesse of aanwezigheid van faciliteiten met betrekking tot diabetes in de opleidingspraktijk

Voor de vragenlijst zelf en de verdeling van de respondenten over de mogelijke antwoorden wordt verwezen naar bijlage 7 . Hieronder volgen enkele vermeldenswaardige resultaten (Dezelfde gegevens van de deelnemers aan toets 2 zijn samen met deze gegevens opgenomen in tabel 12).

Ruim eenderde van de deelnemers was ouder dan 30 jaar. Bijna $70 \%$ bestond uit mannen. Het merendeel van de huisartsen-in-opleiding $(80 \%)$ was langer dan 1 jaar maar korter dan drie jaar afgestudeerd. Dit geeft een beeld van de wachttijd voor de huisartsopleiding, die omstreeks 1985 dus ongeveer twee jaar was.

De vraag naar werkervaring in de gezondheidszorg bracht aan het licht dat een groot deel van de deelnemers tussen afstuderen en start beroepsopleiding gewerkt had.

Voor dit onderzoek was het relevant om na te gaan of men na het afstuderen als basisarts ergens had gewerkt, waar intensief kontakt met diabetespatięnten waarschijnlijk was. Hierbij kan gedacht worden aan huisartspraktijken, waar het assisteren onder supervisie zonder huis-artsregistratie mogelijk is: $11 \%$ van de deelnemers bleek hier werkzaam te zijn geweest.

Ook werkzaamheden in verpleeghuizen kunnen relevant zijn, omdat in verpleeghuizen veel patienten met diabetes zijn opgenomen. In deze sector bleken slechts een paar deelnemers te hebben gewe.kt. In een polikliniek voor interne geneeskunde kan ook een concentratie van patienten met diabetes worden verwacht. Maar liefst $16 \%$ van de huisartsen-in-opleiding bleek hier enige tijd te hebben gewerkt.

Over het bestuderen van literatuur over diabetes mellitus werd het volgende gemeld: de helft van de onderzochte groep had hieraan in het afgelopen jaar minder dan eén uur besteed, $25 \%$ 1-2 uur en de overige $25 \%$ gaf aan meer dan 2 uur hieraan te hebben besteed. Een bovengrens was niet goed aangegeven in het formulier. Bijna niemand van de 219 deelnemers nam deel aan een nascholingsactiviteit over diabetes in het voorafgaande jaar.

Het blijkt uit de antwoorden op de vraag naar specifieke activiteiten op het gebied van diabetes mellitus, b.v. het organiseren van speciale spreekuren voor patienten met diabetes mellitus, dat $90 \%$ van de opleiders geen bijzondere affiniteit met de diabetesbehandeling heefe.

Na het beschukbaar komen van de toetsscores van de deelnemers is geprobeerd om een correlatie te vinden tussen bovengenoemde achtergrondkenmerken van de deelnemers en hun toetsscore. Hiertoe werden de toetsresultaten in een drietal niveaus ingedeeld en werd. vervolgens met behulp van de Chi kwadrat-toets nagegaan of per afzonderlijk achtergrondkenmerk correlaties gevonden werden.

Deze bewerking leverde geen resultaat op, mede door een onvoldoende vulling van de diverse 'cellen'.

\subsection{Institutsgebonden onderwijsprogramma's}

Bij een onderzoek naar kennis over een specifiek onderwerp is het van belang om naast de informatie over extra praktijkervaring, zelfstudie en nascholing ook een beeld te hebben, van, het onderwijsaanbod van de instituten, zoals dat gegeven wordt op de wekelijkse terugkomdagen. Aangezien de instituten volledig autonoom waren bij de invulling van het opleidingsprogramma 
en aangezien de opleidingsgroepen per instituut bovendien niet noodzakelijkerwijs hetzelfde opleidingsprogramma doorliepen, kunnen per deelnemer verschillen in het verkregen onderwijsaanbod optreden.

Om een beeld te krijgen van de aandacht, die in de beroepsopleiding per instituut en per groep werd besteed aan het onderwerp diabeteszorg, werd hierover na afloop van het project in 1987, dus retrospectief, informatie verzameld met behulp van een vragenlijst. De enquete bestond uit twee delen (zie bijlage 8 ).

Deel I was bestemd voor de coordinatoren van de beroepsopleiding. Hierin werden vragen gesteld over de beschikbaarheid op het instituut van programmałs over diabetes mellitus tijdens de looptijd van het onderzoek, de programmaduur en het tijdstip in de opleiding waarop het programma werd gegeven. Tenslotte werd gevraagd of anno 1987 (tijdstip van beantwoording) cursusprogrammak over diabetes werden aangeboden.

In deel II van de enquête werd per opleidingsgroep gedetailleerd nagevraagd wat aan 'diabetes' in de groep was gedaan. De coórdinator van de beroepsopleiding kreeg het verzoek om deel II door de huisartsbegeleider voor de eigen opleidingsgroep te laten invullen. De naam van de betrokken begeleider werd op de lijst ingevuld.

\subsubsection{Respons}

Zes van de acht algemene lijsten werden geretourneerd. De instituten 3 en 5 lieten verstek gaan. Op groepsniveau bleek, dat het met name door personeelsverloop na een jaar moeilijk was om de betrokken groepsbegeleiders te bereiken. Van de 28 aangezochte groepsbegeleiders kwamen 11 reacties retour. Door de lage respons is het niet zinvol om deze reacties te bespreken. Gezien het personeelsverloop werd het niet zinvol geacht om te trachten door het sturen van een rappel meer informatie te verzamelen.

\subsubsection{Resultaten}

Volstaan wordt met het vermelden van de informatie op instituutsniveau, zoals deze verstrekt is door de coôrdinatoren.

Alleen bij de instituten 1 en 8 was sprake van een regulier programma over diabetesbehandeling. Instituut 1 verzorgde een diabetesprogramma van een hele dag, waarbij tevens een patiêntengroep van de Diabetes Vereniging Nederland ingeschakeld werd, oin de psychosociale en praktische aspecten van de aandoening onder de aandacht te brengen. Het programma werd aangeboden halverwege het opleidingsjaar, dus na de afname van toets 1 .

Instituut 2 meldt, dat men destijds geen regulier programma had. De groepen die meededen aan de diabetestoets organiseerden zelf een nabespreking van de toets gedurende een middag. Van instituut 3 en 5 is langs informele weg bekend dat in de geteste groep eenmalig aandacht werd besteed aan het onderwerp diabetes mellitus.

Bij instituut 4 was er geen regulier programma, maar werd regelmatig door de huisartsen-inopleiding zelf middels referaten of casuistiek aandacht aan de diabeteszorg besteed. Dit duurde volgens opgave ongeveer 2 uur en vond ongeveer halverwege de opleiding plaats.

Bij instituut 6 had het onderwerp diabetes ook geen vaste plaats in de opleiding. Er was wel een draaiboek beschikbaar voor groepen, die kozen voor dit onderwerp. De diabetestoets werd nabesproken, indien de groep dat wenste. Daarvoor werd dan ongeveer een dagdeel uitgetrokken.

Instituut 7 had geen diabetes op het programma staan. Men gaf aan dat bijna elke groep wel aandacht aan het onderwerp besteedde, maar niet op een uniforme manier.

Bij instituut 8 had het programma over diabetes de omvang van 1 dagdeel. Het werd door de huisartsen-in-opleiding zelf voorbereid aan de hand van voorbereidingsadviezen. Het programma werd aangeboden tussen de derde en negende opleidingsmaand, dus na afname van toets 1 . 
Concluderend kan gesteld worden, dat in de beroepsopleiding tot huisarts in zeer wisselende mate aandacht wordt besteed aan de behandeling van type II diabetes in de huisartspraktijk. Het lijkt daarom ook niet zinvol om de toetsresultaten van de deelnemers van een bepaald instituut te relateren aan de bovenstaande gegevens over de hoeveelheid bestede formele onderwijstijd, aangezien de relatie onderwijsaanbod en gemiddelde score op grond van de beschikbare informatie over het onderwijsaanbod niet goed te bepalen is.

Wanneer men naar de huidige situatie in de tweejarige opleiding (anno 1991) kijkt, dan blijkt in de Centrale Programmabank van het Samenwerkingsverband-IOH, waarin alle schriftelijk vastgelegde landelijk toepasbare onderwijsprogrammas (inclusief die voor instructie van vaardigheden) zijn gearchiveerd, drie onderwijsprogramma's (1) en eén programma voor de instructie van de voetcontrole bij een patient met diabetes (2) aanwezig te zijn. De titels van deze programma's zijn: Voetcontrole bij een patiênt met diabetes, Diabetes mellitus II en Diabetes mellitus $(2 \mathrm{x})$. Hoe vaak er gebruik wordt gemaakt van deze programma's wordt niet geregistreerd.

\subsection{Afname van de toets}

De toets werd op de instituten tijdens de wekelijkse terugkomdag onder toezicht gemaakz. Hiervoor was een uur beschikbaar. Na verwerking van de toetsgegevens ontving elke deelnemer in een gesloten envelop de eigen toetsresultaten uitgedrukt in totaalscore en uitgesplitst per rubriek en per casus, voorzien van een toelichting en de gehanteerde antwoordsleutel. Daarnaast werd een overzicht gegeven van de gemiddelde landelijke score over de gehele toets, per rubriek en per casus. Deze manier van terugkoppeling van toetsresultaten komt duidelijk tegemoet aan de wens van proefpersonen om op de hoogte gesteld te worden van resultaten van onderzoek waaraan wordt meegewerkt. Daarnaast bleek de gegeven terugkoppeling goed bruikbaar bij het nabespreken van de toets in de instituten.

\subsection{Procedure opschonen toetsvragen}

Toets 1 telt 126 vragen, verdeeld over 17 casus met daarnaast 18 niet casus-gebonden vragen. $\mathrm{Na}$ afname van de toets werden de commentaren van de deelnemers verzameld en werden itemparameters berekend ( $\mathrm{p}$-waarde, $\mathrm{RIT}=$ itemtotaalcorrelatie).

Op grond van het commentaar van de deelnemers werden fouten in de formulering opgespoord. Verder werd de relevantie van het commentaar bekeken.

Dit leidde tot verwijdering van negen vragen te weten vraag $9,12,14,40,41,74,95,123$ en 124 :

- vraag $9 \quad$ is niet goed geformuleerd.

- vraag $12 \quad$ : geeft niet duidelijk aan hoe de gezichtsvelden getest worden,

- vraag 14 : bevat een dubbele ontkenning en gaf aanleiding tot onduidelijkheid,

- vraag 40 en 41 : zijn vragen over verstrekkingen waarbij achteraf bleek dat zich tijdens de toetsafnameperiode wijzigingen in het verstrekkingen-pakket voor diabetespatiênten hadden voorgedaan.

- vraag 74 : vonden meerdere deelnemers te gedetailleerd,

- vraag 95 : is minder goed omdat de hoeveelheid toe te dienen glucose te gering is om in geval van hypoglycaemie altijd direct tot verbetering van het bewustzijn te leiden,

- vraag 123 : was niet duidelijk genoeg op het punt van de soort ploegendienst en het soort werk,

- vraag 124 : werd door meerdere deelnemers als te gedetailleerd beschouwd. Vier vragen vielen af omdat achteraf duidelijk werd, dat 
gevraagd werd naar theoretisch niet eenduidige zaken $(27,45,46,94)$ :

- vraag 27 : het is niet helder aan te geven waarom dit wel of niet juist is.

- vraag 45 : de hartvergroting is niet betrouwbaar te onderzoeken met behulp van alleen fysisch diagnostisch onderzoek.

- vraag 46 : het is niet duidelijk of een causaal verband tussen diabetes en hypertensie bestaat.

- vraag 94 : hier speelt het probleem, dat alcoholgebruik tot hypoglycaemie kan leiden, maar dat dit bij bier minder waarschijnlijk is door het hoge koolhydraatgehalte.

In totaal werden dertien vragen verwijderd uit toets 1 . Voor de verdeling van de vragen over de rubrieken heeft dat de volgende consequenties gehad:

Rubriek 1 verliest 2 vragen $(94,95)$ en bevat nog 14 vragen

Rubriek 3 verliest 2 vragen $(74,124)$ en bevat nog 10 vragen

Rubriek 6 verliest 5 vragen $(9,12,14,45,46)$ en bevat nog 31 vragen

Rubriek 7 verliest 1 vraag (27) en bevat nog 16 vragen

Rubriek 9 verliest 2 vragen $(40,41)$ en bevat nog 6 vragen

Rubriek $10 \quad$ verliest 1 vraag (123) en bevat nog 9 vragen

De overige rubrieken bleven ongewijzigd.

De betrouwbaarheid van de aldus opgeschoonde toets uitgedrukt in de interne consistentiecoefficiênt bedroeg 0.79 . Dit is een acceptabele waarde voor een dergelijke toets. Ter vergelijking: de Maastrichtse Voortgangstoets, die ongeveer 250 items telt, heeft een interne consistentiewaarde die varieert tussen de 0.85 en 0.95 (maximale waarde $a=1.00$ ).

Bij toepassing van de Spearman Brown-formule voor testverlenging komt een inteme consistentie coéfficiênt tot stand van 0.88 bij verlenging tot 2 maal de oorspronkelijke lengte ( 2 x $113=226$ vragen) .

\subsection{Resultaten}

De gemiddelde goedscore uitgedrukt in het percentage goed beantwoorde vragen bedroeg $60 \%$. De standdaarddeviatie (SD) bedroeg $8,7 \%$. Hieronder volgen voor toets 1 de gerniddelde goedscores per instituut met de bijbehorende standaarddeviatie en het aantal deelnemers aan de toets. Volgens afspraak met de coórdinatoren van de beroepsopleidingen van de instituterı wordt de identiteit van de instituten niet vermeld.

Tabel 8 Resultaten toets 1 : gemiddelde goedscore, standaarddeviatie en aantal deelnemers per institusut

\begin{tabular}{|l|c|c|c|c|c|c|c|c|c|}
\cline { 2 - 9 } \multicolumn{1}{c|}{} & $\begin{array}{c}\text { Inst } \\
1\end{array}$ & $\begin{array}{c}\text { Inst. } \\
2\end{array}$ & $\begin{array}{c}\text { Inst. } \\
3\end{array}$ & $\begin{array}{c}\text { Inst. } \\
4\end{array}$ & $\begin{array}{c}\text { Inst } \\
5\end{array}$ & $\begin{array}{c}\text { Inst } \\
6\end{array}$ & $\begin{array}{c}\text { Inst } \\
7\end{array}$ & $\begin{array}{c}\text { Inst. } \\
8\end{array}$ & Landelijk \\
\hline Scores & 62 & 63 & 58 & 63 & 54 & 64 & 53 & 63 & 60 \\
\hline $\mathrm{SD}$ & 8,1 & 7,7 & 8,5 & 7,8 & 9,0 & 7,0 & 7,3 & 6,7 & 8,7 \\
\hline $\mathrm{N}$ & 35 & 32 & 24 & 19 & 36 & 35 & 18 & 20 & 219 \\
\hline
\end{tabular}


De verschillen tussen de instituten zijn niet erg groot. Er is een klein maar significant verschil tussen de instituten 5 en 7 enerzijds en de instituten 1, 2, 4, 6 en 8 anderzijds (verschillen zijn significant op het $0.01 \%$ niveau, getoetst met de t-toets, nadere variantie analyse is niet toegepast). Instituut 3 neemt een tussenpositie in. In de volgende figuur geven wij de verschillen tussen de instituten grafisch weer in staafdiagrammen.

Figuur 1 Gemiddelde goedscore per instituut, toets 1

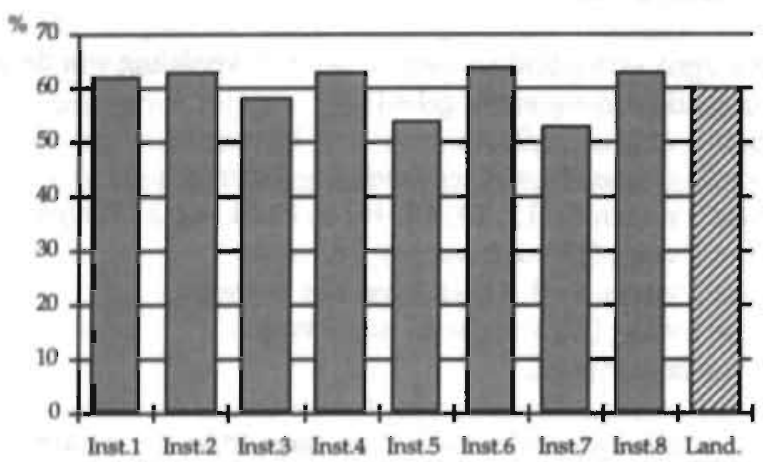

Tenslotte vermelden wij in tabel 9 de gemiddelde goedscore met standaarddeviatie per rubriek.

Tabel 9 Resultaten toets 1: gemiddelde goedscore en standaarddeviatic per rubriek

\begin{tabular}{|c|c|c|l|}
\hline Rubriek & Landelijk & SD & \\
\hline 1 & 81 & 11,6 & Acute situaties bij type I diabetes \\
\hline 2 & 64 & 19,1 & Niet acute situaties bij type I diabetes \\
\hline 3 & 59 & 19,1 & Epidemiologie, erfelijkheid en prognose \\
\hline 4 & 68 & 46,6 & Pathofysiologie \\
\hline 5 & 66 & 16,1 & Diagnostiek van diabetes mellitus \\
\hline 6 & 63 & 10,2 & Diagnostiek van complicaties en ontregeling \\
\hline 7 & 49 & 16,3 & Medicatie, overige therapie en beleid \\
\hline 8 & 42 & 18,8 & Dieet bij diabetes mellitus \\
\hline 9 & 54 & 21,1 & Psychosociale en financiele aspecten van diabetes mellitus \\
\hline 10 & 51 & 18,3 & Diverse, niet in te delen vragen \\
\hline
\end{tabular}

De rubriekscores uitgesplitst per instituut zijn opgenomen in bijlage 6.

\subsection{Bespreking resultaten}

Zoals gezegd zijn de verschillen tussen de instituten niet groot. Bedlacht moet worden dat het hier gaat om een meting vlak na het begin van de beroepsopleiding, op een moment dat nog maar net een start gemaakt is met de zelfstandige hulpverlening door de huisarts-in-opleiding. De scores reflecteren dus vooral het kennisniveau, zoals dit bereikt is in het basiscurriculum 
geneeskunde eventueel aangevuld met kennis opgedaan in de periode tussen het afstuderen en het begin van de beroepsopleiding.

In dit licht bezien bevestigen de gemiddelde goedscores per rubriek de indruk, die men als student gemakkelijk overhoudt van het basiscurriculum geneeskunde. Kennis over diabetes wordt bij de faculteiten der geneeskunde voornamelijk door internisten overgedragen. Dit betekent veel aandacht voor het ziektebeeld van type I diabetes mellitus, voor pathofysiologie en voor de kliniek van de ontregeling. Waarschijnlijk is het zo dat er veel minder aandacht en tijd in de basisopleiding worden besteed aan type II diabetes en aan complicaties die zich voordoen in orgaansystemen, die vallen onder andere specialismen, dan de interne geneeskunde, zoals oogheelkunde en neurologie. Therapie en beleid zijn beide wat minder gangbare onderwerpen in het basiscurriculum. Ook voeding en dieet zijn onderwerpen die weinig belicht worden in de medische basisopleiding (3).

De relatief hoge score op rubriek 1 (acute situaties bij type 1) - zie tabel 9 - is op grond van het bovenstaande te verwachten, de veel lagere score op de rubrieken $7 \mathrm{t} / \mathrm{m} 10$ ook.

Voor voeding en dieet (rubriek 8 ) valt de huisarts vaak terug op hulp van de diètist, mits hij van diens taak en functioneren voldoende op de hoogte is. Medicatie, overige therapie en beleid bij type II (rubriek 7) behoren echter tot de kerntaken van de huisarts. (De rubrieksonderwerpen zijn te vinden in tabel 4).

Uit ons eigen onderzoek lijkt de conclusie gewettigd dat het onderwijs in de basisopleiding op de punten medicatie, therapie en overig beleid bij type II diabetes mellitus tekort schiet. Dit is des te schrijnender als men de getalsmatige duidelijke oververtegenwoordiging van de type II diabetespatiênten boven de type İ diabetespatiênten hierbij betrekt (de prevalentie van type II is minstens $4 \mathrm{x}$ zo hoog als die van type I). Aangezien type II diabetes vooral een aandoening van de oude dag is, zal de toenemende vergrijzing van de Nederlandse bevolking dit verschil in de toekomst nog verder accentueren (4).

Ook uit de dissertatie van Tan (5) blijkt dat de behoefte aan scholing bij huisartsen-in-opleiding aan het begin van de beroepsopleiding groot is. In haar onderzoek geeft $36 \%$ van de huisartsenin-opleiding aan behoefte te hebben aan scholing ten aanzien van de rubriek endocrinologie/voeding en $60 \%$ ten aanzien van therapie. Deze percentages zijn aan het einde van de eenjarige opleiding respectievelijk 12 en 30 .

\section{Literatuur bij hoofdstuk 5}

1. Buijs GCM, Poilemans MC. Centrale Onderwijsbank (COB). Profielbank Onderwijsprogramma's. Periodiek overzicht december 1991. Rapport SV-1OH 19a. Utrecht: Samenwerkingsverband-IOH, 1991.

2. Buijs GCM, Tan LHC. Centrale Onderwijsbank (COB). Profielbank Vaardighedenstations. Periodiek overzicht december 1991. Rapport SV-IOH 19 c. Utrecht: Samenwerkingsverband-IOH, 1991.

3 Hautvast JGAJ. Richtlijnen goede voeding, een mijlpaal voor consument, arts en industrie? Ned. Tijdschr. Geneesk. 1986; 41: 704-6.

4. Chronische ziekten in het jaar 2005. Deel 1 Scenario's over diabetes, mellitus 1990-2005. Stuurgroep Toekomstscenario's Gezondheidszorg. Amsterdam: Bohn, Scheltema \& $z$ Holkema, 1990.

5. Tan LHC. Tekorten in de beroepșopleiding tot huisarts. Ziektebeelden en medisch technische vaardigheden. [dissertatie] Amsterdam: 1989. 
Then

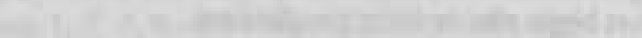

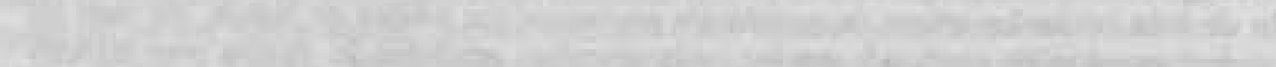

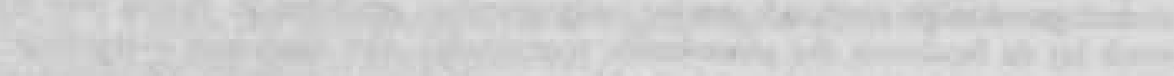

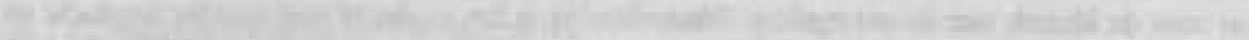

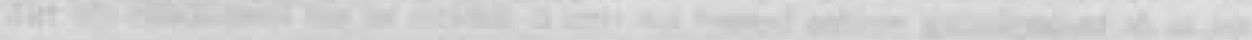

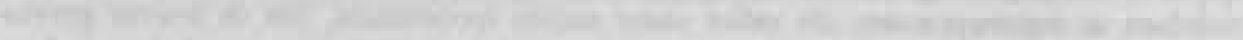

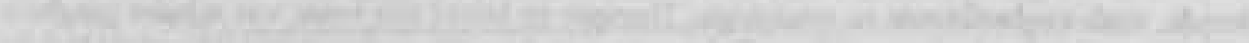

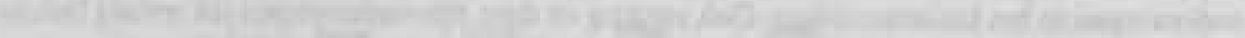

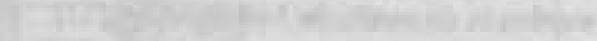

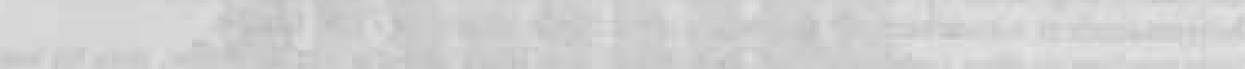

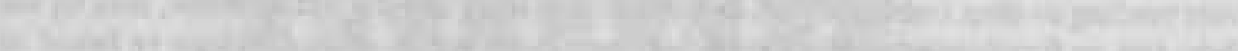

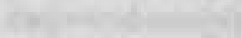

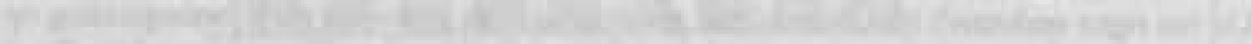

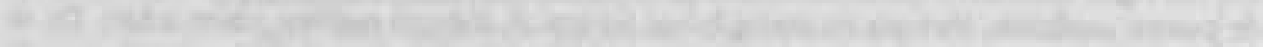

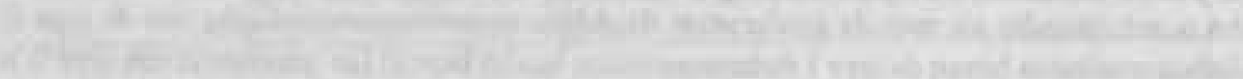

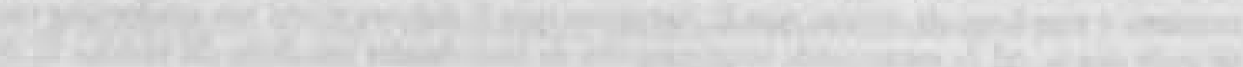

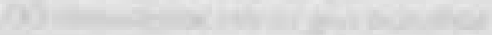

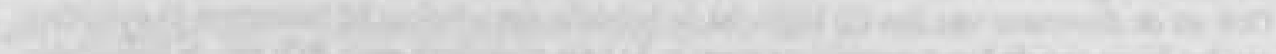

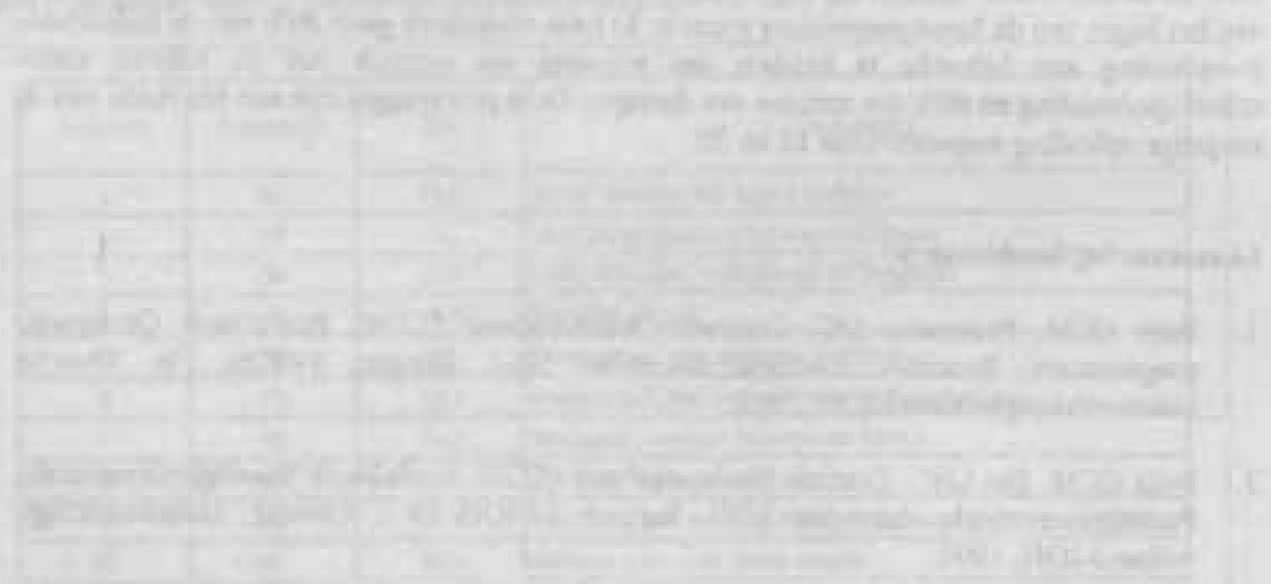

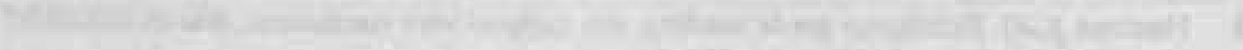

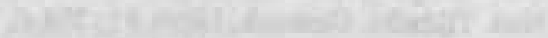

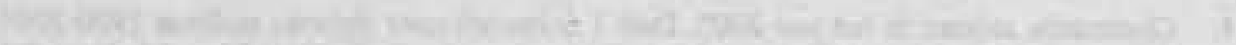

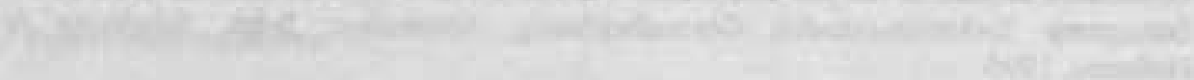

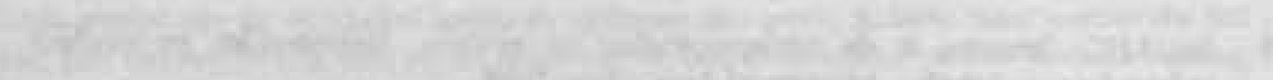

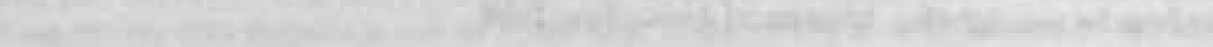
10 


\section{Hoofdstuk 6}

\section{Afname toets 2 bij huisartsen-in-opleiding}

\subsection{Deelnemersbestanden}

Toets 2 werd afgenomen bij 191 huisartsen-in-opleiding, die aan het einde van de beroepsopleiding waren (elfde of twaalfde maand van de eénjarige opleiding). Van hen namen er 131 ook deel aan de beginmeting met toets 1 . Deze 131 deelnemers vormen het longitudinale bestand en worden verder aangeduid als groep $A$.

Van 27 huisartsen-in-opleiding, die beide toetsen maakten werden geen formulieren retour ontvangen van toets 2 . Van 15 deelnemers is de reden daarvan onbekend en van 12 deelnemers (een volledige opleidingsgroep van instituut 5) raakten de formulieren zoek. Naast het longitudinale bestand wordt ook een transversaal bestand onderscheiden van groepen die tén van de twee toetsen maakten. Het gaat om 61 huisartsen-in-opleiding, die alleen toets 1 maakten en 60 huisartsen-in-opleiding, die alleen toets 2 maakten. Het transversale bestand wordt groep B genoemd.

In tabel 10 wordt een overzicht gegeven van de diverse deelnemersbestanden.

Tabel 10 Deelnemersbestanden toets 1 en toets 2

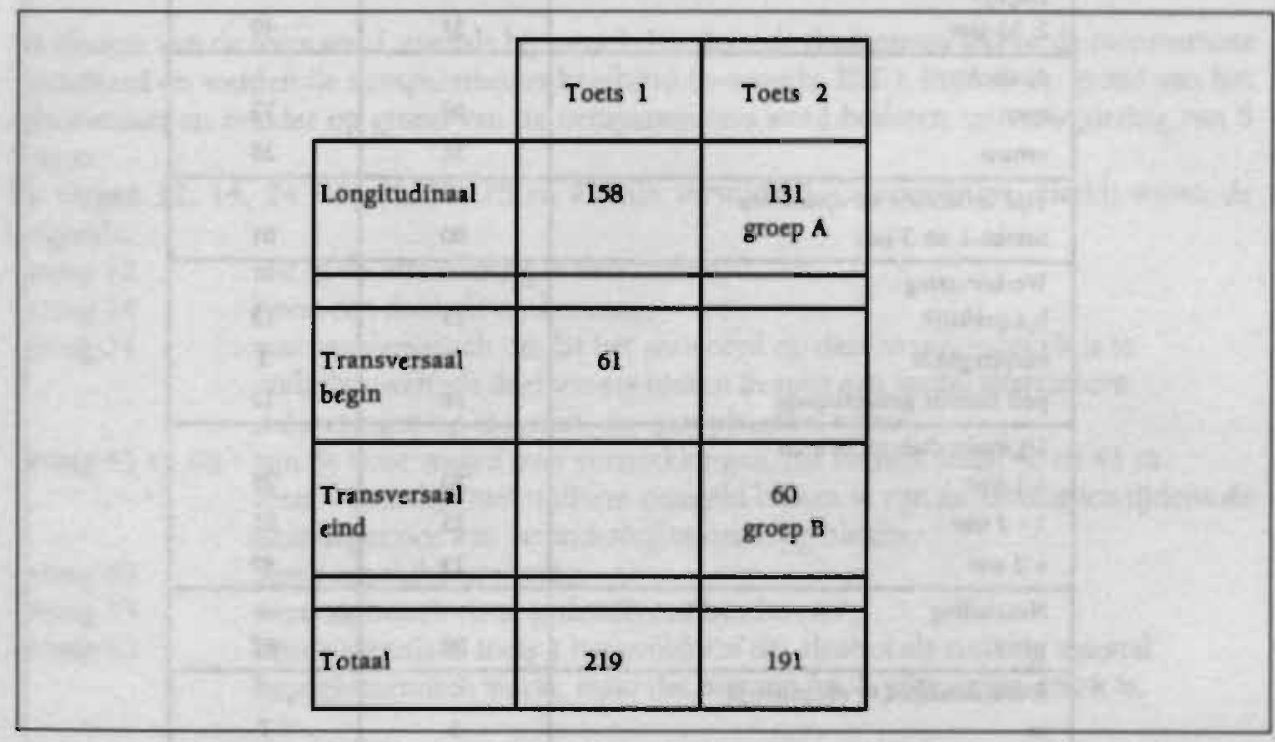

Door de resultaten van groep A met die van groep B te vergelijken kan bekeken worden of er verschil in resultaat is tussen deelnemers, die beide toetsen gemaakt hebben en deelnemers die alleen toets 2 hebben gernaakt. Als het gemiddelde resultaat van groep A en groep B veel zou verschillen - met name als groep A veel hoger zou scoren dari groep B - zou dit kunnen betekenen, dat een sterk herkenningseffect zou zijn opgetreden bij het maken van de tweede toets. Bij de bespreking van de resultaten wordt hierop teruggekomen. 


\subsection{Deelnemerskenmerken}

Net als bij toets 1 zijn ook bij toets 2 gegevens over de deelnemers verzarneld door middel van de eerder genoemde vragenlijst (zie bijlage 5).

De verdeling van de deelnemers naar instituut is weergegeven in tabel 11.

Tabel 11 Aantallen deelnemers toets 2 per instituut

\begin{tabular}{llllllllll}
\hline Instituten & 1 & 2 & 3 & 4 & 5 & 6 & 7 & 8 & totaal \\
H.a. in opl, $\mathrm{n}=$ & 46 & 30 & 21 & 13 & 11 & 35 & 16 & 19 & 191 \\
\hline
\end{tabular}

In tabel 12 worden de resultaten van de deelnemers aan toets, 1 en toets 2 weergegeven, voor zover die kunnen worden ontleend aan de enquete naar achtergrondvariabelen.

Tabel 12 Antwoorden in percentages met betrekking tot achtergrondvariabelen deelinemers toets 1 en toets 2

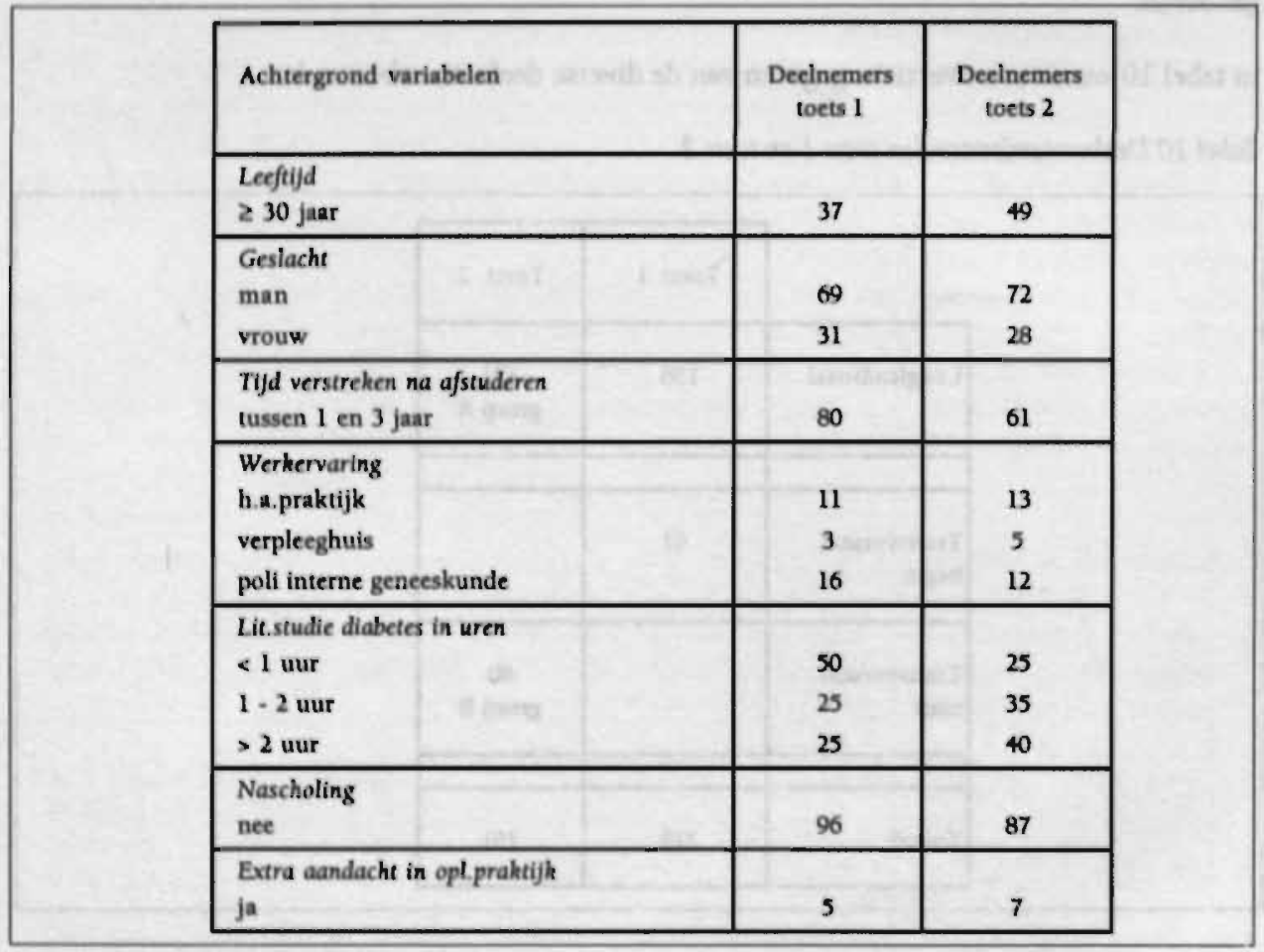

De helft van de deelnemers aan toets 2 was 30 jaar of ouder. Bedacht dient te worden dat een aantal deelnemers bij de deelname aan de tweede toets inmiddels een jaar ouder was geworden. Bijna driekwart ( $72 \%$ ) van de onderzoekspopulatie bestond uit mannen. De meeste huisartsenin-opleiding $(61 \%)$ waren langer dan een jaar maar korter dan drie jaar geleden afgestudeerd.

De vraag naar werkervaring liet een gelijksoortige verdeling zien als bij de deelnemers aan toets 1. Dit is uiteraard ook te verwachten, omdat het grotendeels om dezelfde personen gaat, die alleen inmiddels verder gevorderd zijn in de opleiding. 
$13 \%$ gaf aan in een huisartspraktijk te hebben gewerkt, $5 \%$ in een verpleeghuis, $12 \%$ in een polikliniek Interne Geneeskunde en $60 \%$ kruiste de rubriek 'overige' aan.

Bij het interpreteren van deze vraag is het van belang te weten, dat het in het kader van de beroepsopleiding mogelijk is stage te lopen buiten de huisartspraktijk. Er is in de vraagstelling echter geen onderscheid gemaakt tussen werkervaring opgedaan binnen of buiten de beroepsopleiding.

Bij de vraag over de hoeveelheid bestede tijd aan literatuurstudie over diabetes in het afgelopen. jaar, gaf ongeveer een kwart van de respondenten minder dan één uur aan, een derde tussen de én en de twee uur en $40 \%$ meer dan twee uur. Vergeleken met het bestand van toets 1 heeft men tijdens de beroepsopleiding wat meer tijd besteed aan het bijhouden van de kennis over diabetes. Aangezien in de opleiding enige aandacht aan het onderwerp diabetes mellitus is besteed, verklaart dit de hogere waarde van het aantal bestede uren waarschijnlijk voor een groot deel.

Op het punt van gevolgde nascholing heeft nu $8 \%$ in het afgelopen jaar iets aan nascholing gedaan. Bij de beginmeting was dat vrijwel niemand.

De opleidingspraktijken besteedden in slechts $7 \%$ enige extra aandacht aan diabetesbehandeling.

Als de antwoorden vergeleken worden met die van de deelnemers aan toets 1 komt hetzelfde patroon naar voren.

\subsection{Procedure opschonen toetsvragen}

$\mathrm{Na}$ afname van de toets werd, evenals bij toets 1 , het door de deelnemers geleverde commentaar bestudeerd en werden de itemparameters berekend (p-waarde, RIT ). Primair op grond van het commentaar en minder op grond van de itemparameters werd besloten tot verwijdering van 8 vragen.

De vragen $12,14,24,45,46,59,75$ en 93 zijn verwijderd. Overwegingen hierbij waren de volgende:

- vraag 12 : laat in de formulering te veel ruimte,

- vraag 14 : bevat een dubbele ontkenning,

- vraag 24 : was problematisch omdat het antwoord op deze vraag moeilijk is te onderbouwen, de deelnemers bleken in staat een aantal alternatieve redeneringen op te zetten, die zeer plausibel waren,

- vraag 45 en 46 : zijn de twee vragen over verstrekkingen, die evenals vraag 40 en 41 in toets 1 landelijk niet uniform geregeld bleken te zijn en bovendien tijdens de afnameperiode aan verandering onderhevig bleken,

- vraag 59 : bleek een dubieuze vraag.

- vraag $75 \quad$ : werd algerneen als te gedetailleerd beschouwd,

- vraag 93 : kende evenals in toets 1 het probleem dat alcohol als zodanig meestal hypoglycaemisch werkt, maar dat bier een koolhydraatrijke drank is.

Voor het aantal vragen per rubriek betekent dit het yolgende:

Rubriek 1

Rubriek 3

Rubriek 6

Rubriek 9

verliest 2 vragen $(59,93)$ en bevat nog 14 vragen

verliest 1 vraag (75) en bevat nog 9 vragen

verliest 3 vragen $(12,14,24)$ en bevat nog 29 vragen

De overige rubrieken bleven ongewijzigd.

De betrouwbaarheid uitgedrukt in de interne consistentie-coéfficiênt berekend over de overgebleven 116 vragen bedroeg 0.79 . Bij toets 1 werd eveneens een interne consistentie van 0.79 bereikt. 


\subsection{Resultaten}

De gemiddelde goedscore op toets 2, uitgedrukt in het percentage goed beantwoorde vragen bedroeg 70\%. De standaarddeviatie (SD) bedroeg $8,1 \%$. In tabel 11 vermelden we de gemiddelde goedscore per instituut bij toets 2, de SD en het aantal deelnemers.

Tabel 13 Gemiddelde goedscore per instituut, standaarddeviatie (SD) en aantal deelnemers toets 2

\begin{tabular}{|l|c|c|c|c|c|c|c|c|c|}
\hline \multicolumn{1}{|c|}{} & $\begin{array}{c}\text { Inst. } \\
1\end{array}$ & $\begin{array}{c}\text { Inst. } \\
2\end{array}$ & $\begin{array}{c}\text { Inst } \\
3\end{array}$ & $\begin{array}{c}\text { Inst } \\
4\end{array}$ & $\begin{array}{c}\text { Inst } \\
5\end{array}$ & $\begin{array}{c}\text { Inst } \\
6\end{array}$ & $\begin{array}{c}\text { Inst } \\
7\end{array}$ & $\begin{array}{c}\text { Inst. } \\
8\end{array}$ & Landelijk \\
\hline Scores & 68 & 72 & 68 & 69 & 68 & 72 & 66 & 76 & 70 \\
\hline SD & 6,7 & 5,0 & 7,6 & 6,9 & 9,9 & 6,7 & 10,4 & 9,2 & 8,1 \\
\hline $\mathrm{N}$ & 46 & 30 & 21 & 13 & 11 & 35 & 16 & 19 & 191 \\
\hline
\end{tabular}

Hieronder volgen de instituutsscores in percentages goed beantwoorde vragen omgezet in staafdiagrammen.

Figur 2 Gemiddelde goedscore per instituut, toets 2

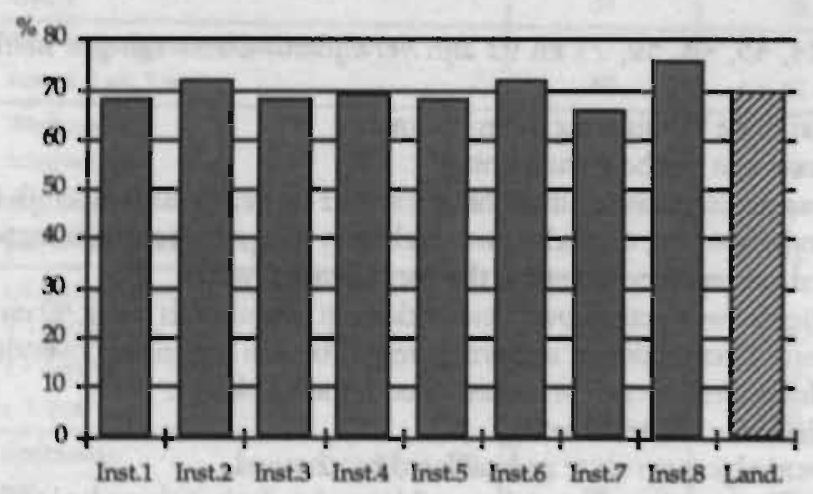

Tabel 13 en figuur 2 laten zien dat de instituutsscores betrekkelijk dicht bij elkaar zijn gekomen. Alleen instituut 7 scoort wat lager. Instituut 8 scoort wat hoger.

Als de aantallen deelnemers bekeken worden, valt op dat instituut 1 met 46 deelnemers disproportioneel sterk vertegenwoordigd is. Hierbij steken de 11 deelnemers van instituut 5 , waar immers een grote uitval van deelnemers was, wel wat mager af.

De waarden van de standaarddeviatie lopen wat meer uiteen dan bij de eerste afname. Dit wijst op individueel meer uiteenlopende scores.

Vervolgens wordt de scoreverdeling per rubriek met standaarddeviatie in tabel 14 gepresenteerd. 
Tabel 14 Resultaten diabetestoets toets 2, rubriekscores. Gemiddelden, uitgedrukt in percentage goede antwoorden.

\begin{tabular}{|c|c|c|l|}
\hline Rubriek & Landelijk & SD & \\
\hline 1 & 78 & 11,1 & Acute situaties bij type I diabetes \\
\hline 2 & 64 & 17,6 & Niet acute situaties bij type I diabetes. \\
\hline 3 & 67 & 14,6 & Epidemiologie, erfelijkheid en prognose \\
\hline 4 & 80 & 23,8 & Pathofysiologie \\
\hline 5 & 79 & 12,4 & Diagnostick van diabetes mellitus \\
\hline 6 & 71 & 9,9 & Diagnostiek van complicaties en ontregeling \\
\hline 7 & 68 & 13,1 & Medicatie, overige therapie en beleid \\
\hline 8 & 60 & 19,6 & Dieet bij diabetes mellitus \\
\hline 9 & 65 & 18,8 & Psychosociale en financiele aspecten van diabetes mellitus \\
\hline 10 & 63 & 17,1 & Diverse, niet in te delen vragen \\
\hline
\end{tabular}

De rubriekscores, uitgesplitst per instituut, zijn opgenomen in bijlage 7.

De zeer grote standaarddeviatie bij rubriek 4 berust op het feit dat deze rubriek slechts twee vragen bevatte.

Bij het bekijken van de verschuiving van de positie van de rubriekscores ten opzichte van elkaar in de beginmeting en de eindmeting doet zich de vraag voor of er sprake is van een herinneringseffect dat opgetreden zou kunnen zijn door het invullen van de beginmeting.

Om dit te beoordelen worden de gemiddelde scores van groep A (131 huisartsen-in-opleiding die ook aan de beginmeting meededen) en groep B ( 60 huisartsen-in-opleiding die niet aan de beginmeting meededen) vergeleken:

\begin{tabular}{lllll}
\hline Groep A & $N=131$ & Percentage goed $=70,8$ & $S D=8,09$ \\
Groep B & $N=$ & 60 & Percentage goed $=68,0$ & $S D=6,72$ \\
\hline
\end{tabular}

Er blijkt een klein verschil te zijn tussen het gemiddelde resultaat op de eindmeting van groep A en $B$, dit verschil is echter niet significant ( $t$-toets).

\subsection{Bespreking}

Bovenstaande resultaten geven het niveau van kennis aan, aan het eind van de énjarige beroepsopleiding tot huisarts. De resultaten per instituut liggen dicht bij elkaar.

Instituut 8 behaalt de hoogste score, significant hoger dan instituut $1,3,4,5$ en 7 ( $p<0,05, t$ toets). Instituut 7 behaalt de laagste score, significant lager dan instituut 2,6 en 8 ( $p<0,05$, ttoets).

Bij de rubriekscores valt de gelijkmatige verdeling van de scores per rubriek op. Rubriek 1 (acute situaties bij type 1) blijft relatief hoog scoren, maar rubriek 4 (pathofysiologie) en rubriek 5 (diagnostiek) liggen op hetzelfde niveau. De rubrieken $3 \mathrm{Vm} 9$, waarin vragen zijn opgenomen over type II diabetes, doen niet meer onder voor de rubrieken 1 en 2 , die onderwerpen behandelen over type I diabetes. 
Op grond van de scorevergelijking tussen groep A en B mag gesteld worden dat het herinneringseffect te verwaarlozen is. De tijd tussen de beide metingen. (ongeveer negen maanden) is blijkbaar lang genoeg om herkenbare herinneringseffecten te voorkomen. Om te kunnen bepalen of de verschillen in begin- en eindscores ook verwijzen naar verschillen in het kennisniveau moet worden nagegaan of toets 1 en toets 2 vergelijkbaar zijn in moeilijkheidsgraad. De wijze waarop deze vergelijking is gemaakt, wordt beschreven in hoofdstuk 8 .

\section{Literatuur bij hoofdstuk 6}

1. Verwijnen GM, Imbos T, Van Hessen PAW, Wijnen WHFW. What's in the score. An. exploratory analysis of true/false test scores. PES publicaties no. 160. Maastricht: Rijksuniversiteit Limburg, 1987. 


\section{Hoofdstuk 7}

\section{Afname toets 1 bij ervaren huisartsen}

\subsection{Deelnemers en procedure.}

In het kader van het onderzoek naar het kennisniveau met betrekking tot diabetesbehandeling van huisartsen-in-opleiding bleek het mogelijk om eveneens zicht te krijgen op prestaties van praktizerende huisartsen. In het traject van basisopleiding geneeskunde naar beroepsopleiding tot huisarts en vervolgens praktijkuitoefening vormt de huisarts practicus het eindpunt. Het is dus interessant om te zien hoe de toetsresultaten van de huisartsen-in-opleiding zich verhouden tot die van ervaren huisartsen, van wie de resultaten als referentiewaarde kunnen worden beschouwd.

\subsubsection{Procedure}

Eind 1985 werd toets 1 in vijf zittingen aan een groep van in totaal 62 huisartsen voorgelegd. Deze groep was geen a-selecte steekproef uit het totaal van de ruim 6000 Nederlandse huisartsen. Hoewel de groep $1 \%$ van alle gevestigde Nederlandse huisartsen omvat is er sprake van selectie om de volgende redenen:

- tweederde van de deelnemers was afkomstig uit de groep huisartsopleiders van de beide Amsterdamse opleidingen (het gaat hier om ervaren, meestal fulltime praktizerende huisartsen die in affiliatie: met een universitair huisartsinstituut een huisarts-in-opleiding in hun praktijk begeleiden en laten praktizeren). Huisartsopleiders worden door de instituten geselecteerd op grond van een aantal randvoorwaarden met betrekking tot de mogelijkheden voor het opdoen van leerervaringen (1).

- bijna éénderde van de deelnemers bestond uit huisartsen die niet gelieerd waren aan de beroepsopleiding. Het gaat hier voornamelijk om een groep in Limburg praktizerende huisartsen uit een waarneemgroep en een scholingsgroep, waar de auteur deel van uitmaakte. Voor het: verkrijgen van een indruk van het niveau van de ervaren huisarts lijkt de gevolgde werkwijze geen belangrijke nadelen te hebben. Systematische vertekening zou te verwachten zijn bij huisartsen met extra scholing of ervaring met diabetesbehandeling.

Bij de vijf zitringen werd telkens op de volgende manier te werk gegaan: de toets en het project werden kort toegelicht, vervolgens werd een uur uitgetrokken voor het maken van de toets. Tot slot werd de toets door de deelnemers becommentarieerd en nabesproken om een zo hoog mogelijk rendement voor de dagelijkse praktijkuitoefening te verkrijgen.

Bij de twee zittingen in Limburg was de toenmalige coórdinator van de diabetespolikliniek van het Academisch Ziekenhuis Maastricht (E. Beukers, internist) beschikbaar als gesprekspartner in de nabespreking.

\subsubsection{Achtergrondkenmerken}

Om enig zicht te krijgen op de kenmerken van de deelnemers, kreeg ieder een korte vragenlijst voorgelegd over de volgende onderwerpen:

- duur van de loopbaan als huisarts

- werkverband

- praktijkgrootte

- percentage bejaarden in de praktijk

* het al dan riet zelf behandelen van type II diabetespatiênten.

- speciale praktijkactiviteiten gericht op diabetespatiênten, zoals een apart diabetes-spreekuur 
- hoeveelheid tijd besteed aan literatuurstudie over diabetes in het afgelopen jaar

- hoeveelheid tijd besteed aan formele nascholing over diabetes.

Voor de vragenlijst zelf wordt verwezen naar bijlage 5 .

De resultaten waren als volgt:

\section{- Duur van de loopbaan als huisarts}

De meerderheid (60\%) van de deelnemers, was langer dan 10 jaar gevestigd als huisarts. Bij ruim eénderde (34\%) was dat tussen de 5 en 10 jaar. Een klein deel (6\%), was nog geen 5 jaar werkzaam als huisarts. We hebben dus overwegend te maken met ervaren huisartsen.

\section{- Organisatie werkverband}

Precies de helft van de respondenten was als solist gevestigd. Bijna een kwart (23\%) werkte in associatief verband, terwijl $16 \%$ deel uit maakte van een gezondheidscentrum en $5 \%$ van een groepspraktijk. De resterende huisartsen (6\%) waren niet in een van bovengenoemde praktijkvormen werkzaam. Deze verdeling lijkt veel op de verdeling van praktijkvormen van de Nederlandse huisartsen in 1986 (2). Alleen het percentage respondenten, dat in een gezondheidscentrum werkzaam is, is wat groter dan gemiddeld (16 versus 7,2 landelijk).

\section{- Praktijkgrootte}

De grootste groep van de respondenten blijkt een, qua praktijkgrootte, zogenaamde normpraktijk (destijds 2400 patienten) te hebben: $44 \%$ van de respondenten geeft aan tussen. de 2000 en 2500 patiênten ingeschreven te hebben. Een kwart (24\%) heeft een praktijk van 2500 tot 3000 patiénten. Een klein gedeelte $(5 \%)$ heeft. een nog grotere praktijk. Ruim een kwart (27\%) heeft minder dan 2000 patiênten.

\section{- Percentage ouderen in de praktijk}

He! gemiddelde pencentage 65-plussers in de bevolking bedroeg 12 in 1985 (12). Aan de respondenten werd gevraagd of ze ongeveer hes gemiddelde percentage 65-plussers in de praktijk hadden of veel meer of juist minder. Deze vraag is gesteld, omdat diabetes type II typisch een aandoening van de oude dag is. De prevalentie van de beide typen diabetes samen neemt enorm toe met de leeftijd, van minder dan 1 promille voor de kinderleeftijd (het betreft dan uitsluitend type 1 diabetespatienten) tot meer dan $5 \%$ bij de 65 plussers (vooral type II diabetespatiênten en de op leeftijd gekomen type I patiênten). Een huisarts me! weinig ouderen in zijn praktijk zal derhalve niet of nauwelijks met het ziektebeeld in aanraking komen. Ruim de helft (52\%) gaf aan een gemiddelde omvang aan ouderen in de praktijk te hebben. Een kwart $(26 \%)$ rapporteerde een duidelijk lager percentage ingeschreven bejaarden; $18 \%$ van de ondervraagden meldt een veel hoger percentage bejaarden in de praktijk te hebber. Een klein deel (4\%) kon hierover geen uitspraak doen. Er lijkt een aanzienlijke variatie te zijn in het aantal oudere patiênten in de praktijken van de deelnemers.

- Het al dan niet zelf behandelen yan type II diabetespatiénten

Het overgrote deel $(89 \%)$ van de huisartsen rapporteert zijn of haar patiénten met type II diabetes zelf te behandelen. Slechts $8 \%$ behandelt zelf geen type II diabetespatiénten. Een klein deel (3\%) meldt geen type Il diabetespatiènten te kennen. Deze antwoorden komen goed overeen met de inhoud van het LHV-Basistakenpakket (3) op dit punt, waarin gesteld wordt dat de behandeling van diabetes mellitus, type II, geheel door de huisarts kan geschieden. Ook Rutten e.a. (4) vinden bij een onderzoek naar taakopvattingen dat zowel huisartsen als internisten in meenderheid van mening zijn dat de behandeling van diabetes mellitus type II tot de taken van de huisarts hoort. 
- Praktijkactiviteiten gericht op diabetespatienten

Slechts een klein aantal huisartsen (11\%) ontplooit enige, specifiek op diabetes gerichte activiteiten, zoals diabetesspreekuren, overleg met een dietiste of deelname aan voorlichtingsactiviteiten. De meesten $(89 \%)$ meldden geen bijzondere activiteiten. Dit geeft aan, dat de onderzochte groep niet in belangrijke mate uit extra in diabetes geinteresseerden bestond.

- Hoeveelheid tijd besteed aan literatuurstudie over diabetes in het afgelopen jaar

Bijna driekwart $(72 \%)$ van de respondenten blijkt meer dan een uur besteed te hebben aan het lezen van literatuur over diabetes, $30 \%$ meldt hieraan meer dan twee uur besteed te hebben en ruim een kwart (28\%) geeft aan minder dan een uur besteed te hebben aan het lezen over diabetes. Het plaatsen van deze gegevens in een context is moeilijk, aangezien praktijkpopulatie en ervaring van de individuele huisarts erg uiteen kunnen lopen.

- Hoeveelheid tijd besteed aan formele nascholing over diabetes in de afgelopen twee jaar.

Driekwart van de deelnemers $(76 \%)$ heeft in de gevraagde periode niet deelgenomen aan een of andere vorm van georganiseerde nascholing op dit terrein; $24 \%$ bezocht wel een of andere nascholingsbijeenkomst over diabetes. Ook uit deze antwoorden is op te maken, dat de onderzochte groep als geheel zeker niet bestond uit speciaal in het onderwerp diabetes geinteresseerden.

\subsection{Resultaten}

De gemiddelde goedscore op toets 1 , uitgedrukt in het percentage goed beantwoorde vragen, berekend over dezelfde 113 vragen als die door de beginnende huisartsen-in-opleiding werden beantwoord, bedroeg $67 \%$. De standaarddeviatie was 8,9\%. De scores per rubriek zijn in tabel 15 weergegeven.

Tabel 15 Resultaten toets 1 ervaren huisartsen; gemiddelde goedscore en standaarddeviatie (SD) per rubriek

\begin{tabular}{|c|l|c|c|}
\hline Rubriek & Onderwerp & $\begin{array}{c}\text { Gemiddelde } \\
\text { goedscore }\end{array}$ & SD \\
\hline 1 & acute situaties type I & 81 & 11,3 \\
2 & niet acuut type I & 74 & 18,6 \\
3 & epidemiologie en erfelijkheid & 64 & 21,2 \\
4 & pathofysiologie & 58 & 49,7 \\
5 & diagnostiek & 71 & 13,9 \\
6 & complicaties & 66 & 10,6 \\
7 & medicatie, beleid & 59 & 16,6 \\
8 & dieet & 50 & 18,6 \\
9 & psychosociale en financiele aspecten & 69 & 19,3 \\
10 & diversen & 65 & 15,7 \\
\hline
\end{tabular}

De grote standaarddeviatie bij rubriek 4 berust op het feit dat deze rubriek slechts een vraag bevatte. Figuur 3 geeft de gemiddelde goedscores van de ervaren huisartsen grafisch weer. 
7. Slotman B, Kriegsman D. Suiker op de korrel. Scriptie. Amsterdam: VU huisartsinstituut, 1983.

8. Huisarts en Praktijk 1979 nr. 3. Themanummer over diabetes (Bijlage bij Huisarts en Wetenschap).

9. Rutten GEHM, Cromme PVM, Zuidweg J, Mulder Dzn JD. Huisarts en diabetes type II. Een verantwoording voor de NHG standaard diabetes mellitus type II. Huisarts en Wetenschap $1989 ; 32: 7-13$.

10. Flavin $\mathrm{KS}$, Gavin III JR. An assessment instrument to measure physicians' knowledge of diabetes management. Journal of Medical Education 1988; 63: 675-81.

11. Hesselt C, Moran A, Boulton AJM. An evaluation of diabetes knowledge amongst general practitioner and senior medical students. Diabetic Medicine 1989; 6: 351-53.

12. Centraal bureau voor de statistiek Ministerie van WVC. Vademecum gezondheidsstatistiek Nederland 1991. Den Haag: SDU uitgeverij, 1991. 


\section{Hoofdstuk 8}

\section{Vergelijkbaarheid: toets 3}

\subsection{Testtheoretische vereisten}

Nadat in hoofdstuk 5 en 7 de resultaten van de beide kennismetingen zijn gepresenteerd ligt het voor de hand om de scores op beide toetsen naast elkaar te leggen en uitspraken te doen over eventuele verschillen. Testtheoretisch is dit echter niet zonder meer mogelijk.

Thorndike (1) zegt hier het volgende over:

"There are occasions when more than one form of a test have been prepared, all designed to measure the same latent attribute...

In the rigorous sense, equating is possible only when all the tests in question are equally precise measures of exactly the same attribute. This means that forms yield the same reliability coefficient, or preferably the same standard error of measurement at each pair of equivalent scores, and that each have the same correlation with a measure of any other given attribute. In general, the conditions are met only when the tests are the same length and do not differ markedly in mean and standard deviation."

Beide toetsen hadden praktisch dezelfde lengte, toets 1113 items en toets 2116 ina itemselectie). De gemiddelde scores zijn niet gelijk ( $60 \%$ goed versus $70 \%$ goed), maar werden ook niet verkregen van in kennis en ervaring vergelijkbare groepen.

Aangezien dit onderzoek met name gericht was op het vaststellen en in kaart brengen van de verschillen in kennis tussen het begin en eind van de beroepsopleiding tot huisarts, werd besloten tot een nader onderzoek naar de vergelijkbaarheid in moeilijkheidsgraad van beide toetsen. Immers als zou blijken dat de tweede toets duidelijk gemakkelijker was dan de eerste zou het verschil in score niet zonder meer toe te schrijven zijn aan een groei in kennis.

\subsection{Toets 3}

Er werd uit beide toetsen een gecombineerde variant geconstrueerd. Aangezien beide toetsen opgebouwd zijn uit casus als kleinste uitwisselbare eenheid en de casus dezelfde inhoudelijke onderwerpen bevatten (bijvoorbeeld casus 7 uit beide toetsen gaat over compliance en dieet) werd besloter, om afwisselend uit beide toetsen een casus te kiezen. Dit resulteerde in een toets 3 , die samengesteld was uit casus $2,4,6,8,10,12,14$ en 16 uit de eerste toets en casus $1,3,5$, $7,9,11,13,15$ en 17 uit de tweede toets. Van de niet casusgebonden vragen werden 8 vragen uit de eerste en 8 vragen uit de tweede toets genomen (respectievelijk vraag $119 \mathrm{~d} / \mathrm{m} 126 \mathrm{en}$ vraag $108 \mathrm{vm} \mathrm{115).}$

Het totaal aantal vragen van toets 3 bedroeg 126 . In tabel 16 wordt de verdeling van de vragen over de rubrieken weergegeven. 
Tabel 16 Verdeling van de vragen over de nubriehen in toets 1 , toets 2 en toets 3

\begin{tabular}{|c|c|c|c|c|c|}
\hline & Rubrick & $\begin{array}{l}\text { Aant vragen } \\
\text { toets } 1\end{array}$ & $\begin{array}{c}\text { Aant. vragen } \\
\text { toets } 2\end{array}$ & $\begin{array}{l}\text { Aant. vragen } \\
\text { toets } 3\end{array}$ & Onderwerp \\
\hline & 1 & 16 & 16 & 16 & $\begin{array}{l}\text { Acute situaties bij type I } \\
\text { diabetes }\end{array}$ \\
\hline & 2 & 7 & 7 & 5 & $\begin{array}{l}\text { Niet acute sifuaties bij } \\
\text { bype I diabetes }\end{array}$ \\
\hline & 3 & 12 & 10 & 11 & $\begin{array}{l}\text { Epidemiologie, erfelijkheid } \\
\text { en prognose }\end{array}$ \\
\hline & 4 & I & 3 & 3 & Pathofysiologie \\
\hline & 5 & 12 & 12 & 11 & $\begin{array}{l}\text { Diagnostiek van diabetes } \\
\text { mellitus }\end{array}$ \\
\hline & 6 & 36 & 32 & 34 & $\begin{array}{l}\text { Diagnostiek van complicaties } \\
\text { en ontregeling }\end{array}$ \\
\hline & 7 & 17 & 20 & (a) & $\begin{array}{l}\text { Medicatie, overige therapie } \\
\text { en beleid }\end{array}$ \\
\hline 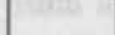 & 8 & 7 & 8 & 8 & Dieet bij diabetes mellitus \\
\hline & 9 & 8 & 9 & 7 & $\begin{array}{l}\text { Psychosociale en financiele } \\
\text { aspecten van diabetes mellitus }\end{array}$ \\
\hline & 10 & 10 & 7 & 11 & $\begin{array}{l}\text { Diverse, niet in te delen } \\
\text { vragen }\end{array}$ \\
\hline wing & totaal & 126 & 124 & 126 & \\
\hline
\end{tabular}

De verdeling van de vragen over de rubrieken in toets 3 wijkt nauwelijks af van die in toets 1 en toets 2 zoals te zien is in bovenstaande tabel. Toets 3, werd afgenomen bij 58 huisartsen-inopleiding van instituut 1 (6 opleidingsgroepen). Deze groep was op het moment van. toetsafname ongeveer halverwege het opleidingsjaar. De toets werd ook nu onder examencondities in het instituut afgenomen.

\subsection{Resultaten}

De gemiddelde score op toets 3 , uitgedrukt in het percentage juist beantwoorde vragen, was voor de 58 huisartsen-in-opleiding $61 \%$. De standaarddeviatie was $8,0 \%$. De scores per rubriek. - in percentages juist beantwoorde viagen - waren als volgt.

\section{Tabel 17 Resultaten toets 3: gemiddelde goedscore per rubriek}

\begin{tabular}{lll}
\hline Rubriek 1 & acute situaties type I & $71 \%$ \\
Rubriek 2 & niet acute situaties type I & $54 \%$ \\
Rubriek 3 & epidemiologie en erfelijkheid & $65 \%$ \\
Rubriek 4 & pathofysiologie & $72 \%$ \\
Rubriek 5 & diagnostiek & $65 \%$ \\
Rubriek 6 & complicaties & $61 \%$ \\
Rubriek 7 & medicatie, overige therapie en beleid & $58 \%$ \\
Rubriek 8 & dieet & $55 \%$ \\
Rubriek 9 & psychosociale en financiéle aspecten & $46 \%$ \\
Rubriek 10 & diversen & $57 \%$
\end{tabular}


Vervolgens gaan we nader in op de scores van de beide samenstellende helften.

Toets 1 kan men opvatten als opgebouwd uit twee helften: I a en I b. Toets 2 kan men eveneens opvatten als opgebouwd uit twee helften: Il a en II b. Beide b-helften - I b en II b - maakten deel uit van toets 3. De delen I a en II a werden niet opgenomen in toets 3.

De gemiddelde scores uitgedrukt in percentage goed beantwoorde vragen van de afzonderlijke delen zijn:

$\begin{array}{lllll}\text { I } & \text { a } & 61 \% & \text { SD } & 8.6 \% \\ \text { I } & \text { b } & 55 \% & \text { SD } & 9.8 \% \\ \text { II } & \text { a } & 69 \% & \text { SD } & 7.8 \% \\ \text { II } & \text { b } & 65 \% & \text { SD } & 8.3 \%\end{array}$

In toets 3 scoort deel

$\begin{array}{lllll}\text { I } & \text { b } & 61 \% & \text { SD } & 10.1 \% \\ \text { II } & \text { b } & 62 \% & \text { SD } & 7.8 \%\end{array}$

Hierbij moet ar rekening mee worden gehouden, dat de scores op toets 1 tot stand kwamen als beginmeting bij de start van de opleiding (gemiddelde goedscore $60 \%$ ) en dat de scores op toets 2 tot stand kwamen aan het eind van de opleiding (gemiddelde goedscore $70 \%$ ).

In figuur 4 is de opbouw van toets 3 grafisch weergegeven.

Figuur 4 Samenstelling van toets 3 uit toets 1 en 2 . Gemiddeld percentage goed beantwoorde vragen per deel

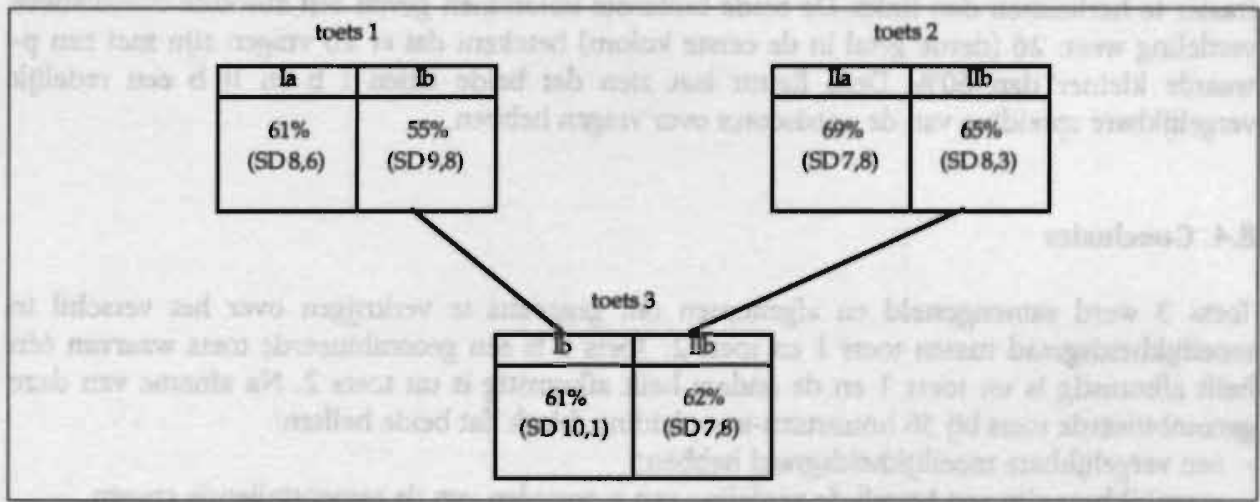

In toets 3 scoort I b iets lager dan II b. Dit verschil is echter niet significant ( $\mathrm{t}$-toets).

Hieruit mag worden geconcludeerd dat beide samenstellende delen nagenoeg even moeilijk zijn.

Ter illustratie wordt in figuur 5 de frequentieverdeling van de goedscores per vraag van de delen $\mathrm{I} b$ en II $\mathrm{b}$ in toets 3 in de vorm van een takbladgrafiek weergegeven. 


\begin{tabular}{lrrlr} 
Takblad I b & \multicolumn{3}{c}{ P-waarde } & Takblad II b \\
\hline & 40 & 023 & & 3 \\
2 & 98 & & 566899 & 9 \\
14 & 444422211111 & 50 & 1124 & 13 \\
26 & 999997776666 & & 555777777888 & 25 \\
$(9)$ & 422211111 & 60 & 0000000222333 & $(13)$ \\
23 & 9999776666666 & & 56666888888 & 20 \\
10 & 4420000 & 70 & 11244 & 9 \\
3 & 975 & & 58 & 4 \\
& & 80 & & 2
\end{tabular}

De middenkolom van deze figuur geeft het percentage goede antwoorden per vraag aan (pwaarde), variêrend van $40 \%$ bovenaan tot $90 \%$ ondenaan. Links en rechts naast de middenkolom staan telkens wisselende getallenreeksen. Elk getal geeft de positie van een vraag weer.

De eerste twee cijfers in takblad $1 \mathrm{~b}$, namelijk 9 en 8 , geven aan dat er 1 vraag in Ib was met een p-waarde van $49 \%$ en 1 vraag met een p-waarde van $48 \%$. Op deze wijze staan links en rechts van de middenkolorn twee frequentieverdelingen gespiegeld weergegeven. (13) geeft aan dat er 13 waarnemingen op de mediaan zijn. Aan de rechterkant is de vorm van een normaalverdeling fraaier te herkennen dan links. De beide buitenste kolommen geven een absolute cumulatieve verdeling weer. 26 (derde getal in de eerste kolom) betekent dat er 26 vragen zijn met een pwaarde kleiner dan $60 \%$. Deze figuur laat zien dat beide delen I b en II b een redelijk vergelijkbare spreiding van de goedscores over vragen hebben.

\subsection{Conclusies}

Toets 3 werd samengesteld en afgenomen om gegevens te verkijgen over het verschil in moeilijkheidsgraad tussen toets 1 en toets 2. Toets, 3 is een gecornbineerde toets waarvan tén helit afkomstig is uit toets 1 en de andere helft afkomstig is uit toets. 2. Na afname van deze gecornhineerde toets bij 58 huisartsen-in-opleiding, bleek dat beide he!ften:

- een vergelijkbare moeilijkheidsgraad hebben;

- vergelijkbaar zijn wat betreft de verdeling van p-waarden van de samenstellende vragen.

Tevens bleek dat de in de gecombinieerde toets gebruikte helften allebei wat moeilijker waren dan de niet gebruikte helften (zie figur 4). Dit verklaart waarom de gemiddelde goedscore op toets 3 , die de moeilijkste delen uit toets 1 en toets 2 in zich combineert, bij afname bij een groep huisartsen-in-opleiding halverwege de opleiding niet hoger is dan $61 \%$, terwijl de gemiddelde score op loets $160 \%$ bedroeg en $70 \%$ op toets 2 .

Concluderend kan de stelling worden verdedigd dat beide toetsen in moeilijkheid niet significant van elkaar verschillen en dat zen toename in score op toets 2 vergeleken met de score: op toets 1 zeer waarschijnlijk mag worden toegeschreven aan een toename in kennis en dat het minder waarschijnlijk is dat de toename kan worden verklaard op grond van een makkelijkere tweede toets, noch op grond van herkenning van yragen door deelnemers die de parallelversie eerder hadden gemaakt. 
Literatuur bij hoofdstuk 8

1. Thomdike LJ. Applied psychometrics. Boston: Houghton Mifflin Company, 1982.

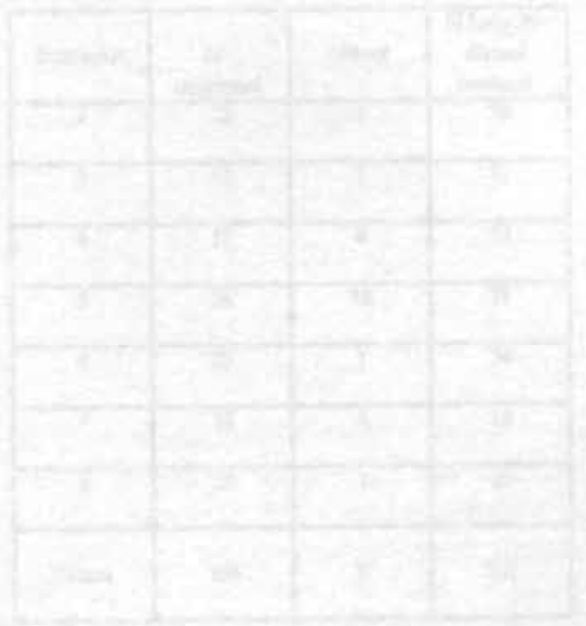




\section{Hoofdstuk 9}

\section{Groei in kennis met betrekking tot diabetesbehandeling gedurende de eenjarige huisartsopleiding}

\subsection{Het longitudinale bestand}

Nadat in de hoofdstukken 5 en 7 de resultaten van de begin- en de eindmeting en de invloed van het instrumenteffect werden besproken en in hoofdstuk 8 beschreven werd dat beide toetsen in moeilijkheidsgraad vergelijkbaar zijn, zal in dit hoofdstuk een vergelijking worden gemaakt tussen begin- en eindmeting. Daartoe werden die huisartsen-in-opleiding geselecteerd uit de deelnemersbestanden van de begin- en eindmeting, die aan beide metingen hadden meegedaan. Op deze wijze werd een nieuw bestand geformeerd van 131 huisartsen-inopleiding. Instituut 1 is in deze longitudinale groep niet meer vertegenwoordigd. Reden hiervoor is, dat de huisartsen-in-opleiding van instituut 1 die aan de beginmeting meededen, vervolgens aan de gecombineerde toets meededen, zodat een deelname aan de eindmeting niet meer mogelijk was, omdat in toets 3 de helft van toets 2 is opgenomen. De huisartsen-inopleiding van instituut 1, die aan dit onderzoek meewerkten, deden alleen mee aan de eindmeting. Zij fungeerden als controlegroep bij het onderzoeken van het herinneringseffect. In tabel 18 wordt een overzicht gegeven van de aantallen deelnemers per instituut.

Tabel 18 Aantallen deelnemers per instituut

\begin{tabular}{|c|c|c|c|c|}
\hline Instituut & $\begin{array}{c}\mathrm{N} \\
\text { origineel }\end{array}$ & Uitval & $\begin{array}{c}\text { Niongitu- } \\
\text { dinal. } \\
\text { bestand }\end{array}$ \\
\hline 2 & 32 & 3 & 29 \\
\hline 3 & 12 & 1 & 11 \\
\hline 4 & 17 & 4 & 13 \\
\hline 5 & 24 & 13 & 11 \\
\hline 6 & 35 & 1 & 34 \\
\hline 7 & 18 & 4 & 14 \\
\hline 8 & 20 & 1 & 19 \\
\hline Total & 158 & 2 & 131 \\
\hline
\end{tabular}

Als we de uitval bekijken valt instituut 5 op. Dit komt door het zoek raken na afname van alle 12 formulieren van een groep. De resterende uitval is betrekkelijk gering en is te verklaren uit niet onderzoeksgebonden oorzaken van absentie, zoals ziekte, vakantie, stage, waarneming en dergelijke. 


\subsection{Resultaten}

Door nu de gemiddelde scores van deze 131 deelnemers op toets 1 en toets 2 te berekenen is: het toegestaan de verschillen tussen de begin- en eindmeting te interpreteren als groei in kennis. Voor alle volledigheid vermelden wij hierbij, dat niet onderzocht is, waardoor de kennistoename precies is opgetreden (door onderwijs op de instituten of door ervaringen in de opleidingspraktijk). In tabel 19 worden de opnieuw berekende resultaten weergegeven van de eerste en de tweede afname bij de 131 huisartsen-in-opleiding die zowel een begin- als een eindtoets maakten.

Tabel 19 Resultaten eerste en tweede afname longitudinale bestand, uitgesplitst naar rubriek en instituut in percentage goed. Significantieniveaus van verschillen in totaalscore tussen eerste en tweede afname

\begin{tabular}{|c|c|c|c|c|c|c|c|c|c|c|c|c|c|c|c|c|}
\hline \multirow{2}{*}{$\begin{array}{l}\text { Rubrieh } \\
\text { Afname }\end{array}$} & \multicolumn{2}{|c|}{ In. 2} & \multicolumn{2}{|c|}{ In. 3} & \multicolumn{2}{|c|}{ In 4} & \multicolumn{2}{|c|}{ ln. 5} & \multicolumn{2}{|c|}{ In. 6} & \multicolumn{2}{|c|}{ in. 7} & \multicolumn{2}{|c|}{ In. $B$} & \multicolumn{2}{|c|}{ Landelijgk } \\
\hline & 1e & $2 e$ & le & $2 \mathrm{e}$ & is & $2 e$ & le & $2 e$ & le & $2 e$ & le & $2 e$ & le & $2 e$ & le & $2 e$ \\
\hline 1 & 78 & 75 & 75 & $n$ & B6 & 68 & $n$ & $\infty$ & 84 & 74 & $\pi 7$ & 7. & 80 & 79 & 80 & 73) \\
\hline 2 & 57 & 55 & 55 & 65 & $n$ & 67 & 60 & 64 & 61 & 6 & 46 & 60 & 52 & 73 & 57 & 64 \\
\hline 3 & 66 & 74 & 54 & 61 & 55 & 69 & 59 & 62. & 66 & 69 & 49 & 61 & 63 & $\pi$ & 61 & $\Leftrightarrow$ \\
\hline 4 & 79 & 87 & 64 & 61 & 85 & 87 & 45 & 79 & 82 & 83 & so & 83 & 68 & 8 & $\pi 2$ & 83 \\
\hline 3 & 75 & 84 & 63 & 80 & 69 & 79 & 63 & 80 & 71 & 80 & 57 & 73 & 66 & 78 & 63 & 80 \\
\hline 6 & 67 & 70 & 69 & 66 & 67 & $n$ & 55 & $n$ & 63 & 73 & 55 & 66 & 67 & 77 & 64 & 71 \\
\hline 7 & 49 & 72 & 52 & 61 & 50 & 63 & 4 & o4 & 55 & 71 & 40 & 58 & 53 & 73 & so & 68 \\
\hline 8 & 47 & 53 & 42 & 52 & 45 & 64 & 4 & 55 & $H$ & 61 & 38 & 66 & 47 & 70 & 4 & 60 \\
\hline 9 & 6. & 64 & 62 & 57 & 58 & 36 & 42 & 55 & 60 & 62 & 16 & 54 & 61 & 68 & 58 & 61 \\
\hline 10 & 52 & 67 & 41 & 69 & 49 & 62 & 47 & or & 55 & 65 & 47 & 57 & 57 & 68 & 31 & 65 \\
\hline Totaal & 63 & 71 & 60 & 65 & 63 & 68 & 55 & 67 & 64 & $n$ & 52 & 64 & 63 & 75 & 61 & 70 \\
\hline Stgu.niv. & \multicolumn{2}{|c|}{$p<0.01$} & \multicolumn{2}{|c|}{ N. S. } & \multicolumn{2}{|c|}{ N. 5.} & \multicolumn{2}{|c|}{$p<0.05$} & \multicolumn{2}{|c|}{$p<0.01$} & \multicolumn{2}{|c|}{$p<0.01$} & \multicolumn{2}{|c|}{$p<0.01$} & \multicolumn{2}{|c|}{$p<0.01$} \\
\hline
\end{tabular}

De gegevens in tabel 19 laten zien dat in het longitudinale bestand de gemiddelde score op toets $161 \%$ bedraagt (was $60 \%$ voor het transversale bestand, zie tabel 8 ). Bij het nalopen van rubriek- en instituutsscores blijken ook hier kleine verschillen op te treden, waarbij het verschil in score op rubriek 2 (niet-acute situaties bij type I) het grootst is ( $64 \%$ versus $57 \%$, zie tabel 9 ). Bij toets 2 blijft de gemiddelde score in beide bestanden $70 \%$ (zie tabel 13). De score op rubriek 1 (acute situaties bij type 1) ligt voor het longitudinale bestand op $73 \%$ versus $78 \%$ in de totale deelnemersgroep. Voor rubriek 9 (psychosociale en financięle aspecten van type II diabetes) geldt dat de score van $65 \%$ op $61 \%$ kornt.

Op instituutsniveau is het verschil bij Instituut 3 het grootst ( $68 \%$ versus $65 \%)$.

De toename in gemiddelde goedscore van de eerste meting vergeleken met de tweede meting in het longitudinale bestand bedraagt $9 \%$. Dit is een significante toename (t-toets, significant op 0.01 niveau). Figuur 6 toont de scores voor de longitudinale groep per instituut van de eerste: en de tweede meting. 
Figuur 6 Resultaten per instituut op cerste en tweede afname. $\%=$ percentage goed beantwoorde vragen : $n=131$

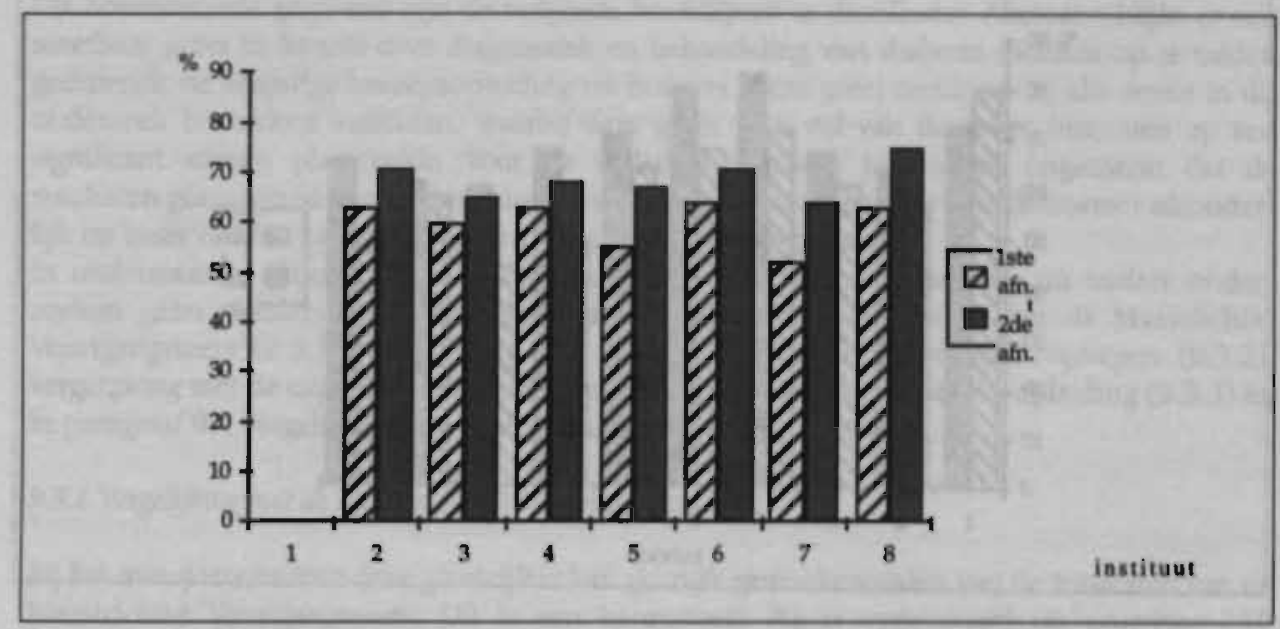

Alle zeven instituten vertonen een toename in het bereikte resultat. Deze toename is bij Instituut 3 en 4 niet significant ( $t$-toets). Vijf van de zeven instituten vertonen dus een significante groei. Bij twee instituten is een tendens in de verwachte richting te constateren. in tabel 20 wordt een overzicht van de significantienivaus van de verschillen tussen voor- en nameting gegeven voor het longitudinale bestand.

Tabel 20 Significantieniveaus van de verschillen tussen toets 1 en toets 2

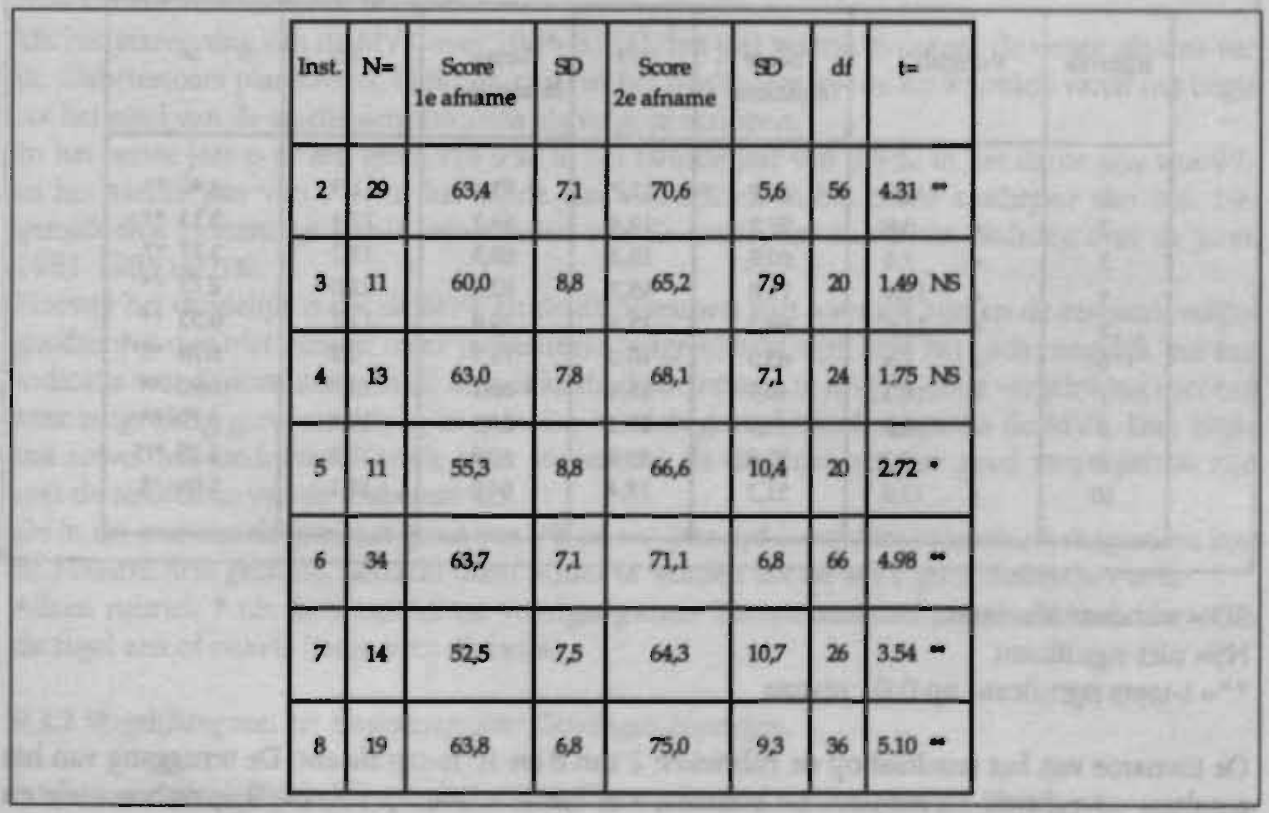

$\mathrm{SD}=$ standaarddeviatie $/ \mathrm{df}=$ degrees of freedom $/ \mathrm{NS}=$ niet significant $/ *=\mathrm{t}$-toets significant op 0.05 niveau $/{ }^{* *}=t$-toets significant op 0.01 niveau

Vervolgens worden de rubriekscores van toets 1 en toets 2 vergeleken in figuur 7 . 


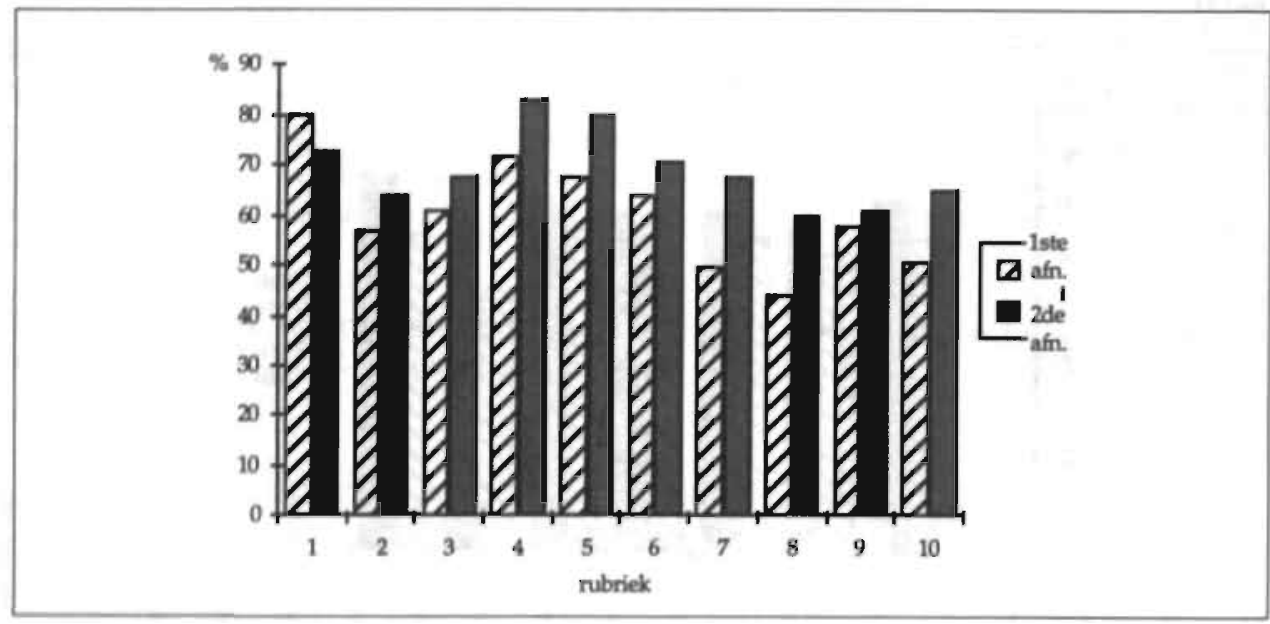

Het valt op dat rubriek 1 (acute situaties bij type 1) een teruggang laat zien. Hiervoor is geen duidelijke verklaring. Mogelijk geeft de teruggang een verschuiving aan in de opbouw van kennis in de loop van het opleidingsjaar. De overige rubrieken laten een groei in kennis zien. In tabel 21 worden de significantieniveaus voor de verschillen in scores per rubriek in voor- en nameting van de 131 huisartsen-in-opleiding getoond $(\mathrm{df}=260)$.

Tabel 21 Significantieniveaus van de verschillen in scores per rubriek in eerste en tweede meting

\begin{tabular}{|c|c|c|c|c|c|c|}
\hline Rubriek & Verschil & $\begin{array}{c}\text { Score } \\
\text { le afname }\end{array}$ & SD & $\begin{array}{c}\text { Score } \\
2 \mathrm{e} \text { afname }\end{array}$ & SD & $t=$ \\
\hline 1 & 6,9 & 79,9 & 11,7 & 73,0 & 11,3 & $4.40 \cdots$ \\
\hline 2 & 6,8 & 57,5 & 19,4 & 64,3 & 17,4 & $3.13 \cdots$ \\
\hline 3 & 7,4 & 60,9 & 19,2 & 68,3 & 15,2 & $3.77 * *$ \\
\hline 4 & $+\quad 11,4$ & 71,8 & 45,2 & 83,2 & 22,0 & $273 * *$ \\
\hline 5 & $+\quad 11,6$ & 68,2 & 15,3 & 79,8 & 12,7 & $6.53 \cdots$ \\
\hline 6 & 7,4 & 63,9 & 10,0 & 71,3 & 9,9 & $6.78 * *$ \\
\hline 7 & $+\quad 18,2$ & 49,9 & 15,4 & 68,1 & 13,7 & $10.90 \cdots$ \\
\hline 8 & $+\quad 16,0$ & 44,3 & 19,2 & 60,3 & 19,4 & $6.79 \approx *$ \\
\hline 9 & $+\quad 3,2$ & 57,6 & 20,6 & 60,8 & 18,5 & $1.27 \mathrm{NS}$ \\
\hline 10 & $+\quad 13,6$ & 51,3 & 18,4 & 64,9 & 17,1 & $5.99 *$ \\
\hline
\end{tabular}

$\mathrm{SD}=$ standaarddeviatie

$\mathrm{NS}=$ niet significant

** $=$ t-toets significant op 0.01 niveau

De toename van het resultaat op de rubrieken $2 \mathrm{t} / \mathrm{m} 8 \mathrm{en} 10$ is significant. De teruggang van het resultaat op rubriek 1 eveneens. De toename van het resultaat op rubriek 9 (psychosociale en financiêle aspecten van type II) blijkt niet significant. 


\subsection{Discussie}

Uit bovenstaande gegevens zijn de volgende hoofdlijnen te destilleren. Allereerst blijkt er een meetbare groei in kennis over diagnostiek en behandeling van diabetes mellitus op te treden gedurende de éenjarige beroepsopleiding tot huisarts. Deze groei treedt op bij alle zeven in dit onderzoek betrokken instituten, waarbij deze groei voor vijf van de zeven instituten op een significant niveau. plaatsvindt. Voor de volledegheid dient te worden opgemerkt dat de resultaten geagregeerd zijn op instituutsniveau en dat uitspraken over elke deelnemer afzonderlijk op basis van het hier gepresenteerde materiaal niet mogelijk zijn.

In onderstaande alinea's zullen de toetsscores uit dit onderzoek naast die uit andere onderzoeken gezet worden. Achtereenvolgens komen aan bod: vergelijking met de Maastrichtse Voortgangstoets (9.3.1), vergelijking met het Evaluatieproject Groningen-Nijmegen (9.3.2), vergelijking met de experimentele landelijke kennistoets voor huisartsen-in-opleiding (9.3.3) en in paragraaf 9.4 vergelijking met de ervaren huisartsen (zie hoofdstuk 7).

\subsubsection{Vergelijking met de Maastrichtse Voortgangstoets (MVT)}

Bij het interpreteren van deze groeicijfers kan gebruik gemaakt worden van de resultaten van de Maastrichtse Voortgangstoets. Dit is een kennistoets die is opgebouwd uit ongeveer 250 juist//onjuist vragen, verdeeld over 15 rubrieken, die samen het hele veld van het basiscurriculum geneeskunde bestrijken.

Aangezien alle docenten, die verbonden zijn aan de medische faculteit in Maastricht steeds nieuwe vragen aanleveren, is in de loop der jaren een zeer grote itembank tot stand gekomen, waaruit 4 keer per jaar een toets wordt samengesteld. Elke student neemt verplicht deel aan deze toets vanaf de start van de studie tot aan het eind. Hierdoor zijn getallen bekend over de toename in kennis per jaar.

Het zal duidelijk zijn, dat specifiek op de huisartspraktijk gerichte vragen een kleine minderheid vormen in de MVT .

Uit het jaarverslag van de MVT over 1984-85 (1), het jaar waarin eveneens de eerste afname van de diabetestoets plaatsvond, blijkt de groei in het percentage goede antwoorden vanaf het begin tot het eind van de studie geneeskunde als volgt te verlopen.

In het eerste jaar is er een groei van $9 \%$, in het tweede jaar van $8,5 \%$, in het derde jaar van $9 \%$, in het vierde jaar van $7 \%$, in het vijfde jaar van $5 \%$ en in het zesde studiejaar van $3 \%$. Het gemiddelde percentage goede antwoorden varı de zesdejaars studenten bedroeg over de jaren $1981-198560,6 \%$.

Hoewel het duidelijk is dat de MVT en de diabetestoets niet identiek zijn en de respectievelijke goedscores dus niet zonder meer rechtstreeks vergelijkbaar zijn, lijkt het toch mogelijk om een indicatie van de kwaliteit van de ontwikkelde diabetestoets te krijgen door vergelijking met een zeer zorgvuldig geconstrueerde en extreem kritisch geanalyseerde toets als de MVT. Dan blijkt dat zowel hei eindniveau (zesde jaars studenten) als de groei per jaar goed vergelijkbaar zijn met de resultaten van de diabetestoets.

De in dit onderzoek gemeten groei van $9 \%$ in een jaar tijd is vrij fors te noemen vergeleken met de Maastrichtse getallen. Bedacht dient echter te worden dat de MVT geen diabetestoets is.

Alleen rubriek 7 uit de Maastrichtse Voortgangstoets 'Hormoonstelsel en metabolisme' bevat in de regel een of enkele items, over diabetes.

\subsubsection{Vergelijking met het Evaluatieproject Groningen-Nijmegen.}

Interessant is vergelijking met het. materiaal dat verzameld werd in een deelstudie van een grote onderwijsevaluatiestudie van de beroepsopleidingen tot huisarts van Groningen en Nijmegen (2). In de desbetreffende deelstudie (3), waarin alleen deelnemers uit Nijmegen werden onderzocht, werd een begin- en een eindmeting verkregen van een groep van 33 Nijmeegse 
huisartsen-in-opleiding (3). Dit onderzoek vond plaats in 1984-1985.

Het gemiddelde resultaat in percentage goede antwoorden bij de beginimeting lag imet:57\% (SD $8 \%$ ) iets lager dan de $61 \%$ in ons onderzoek. De score op de eindmeting was $63 \%$ (SD $8 \%$ ). Derhalve een toename van $6 \%$.

De onderzoekers hanteerden de volgende procedure: Er werd uitgegaan van een bestaande versie van de Maastrichtse Voortgangstoets. De ongeveer 250 vragen van de gebruikte MVT werden vooraf door een huisartspanel beoordeeld op geschiktheid voor de deelnemers aan de huisartsopleiding. Als resultaat van deze beoordeling werden 151 vragen geschikt bevonden.

Bij vergelijking van deze subtoets met de hele toets $k$ wamen de scores op de subtoets wat hoger uit, namelijk $63 \%$ bij de eerste meting en $69 \%$ bij de tweede meting. Deze getallen liggen in dezelfde orde van grootte als onze bevindingen met de diabetestoetsen. Dit is op te vatten als een indicatie dat beide instrumenten tot op bepaalde hoogte vergelijkbare eigenschappen hebben.

\subsubsection{Vergelijking met de experimentele landelijhe kennistoets voor huisartsen-in-opleiding}

Sinds 1988 wordt op experimentele schaal tweemaal per jaar een voortgangstoets afgenomen door het Uitvoerend Bureau van het Landelijk Samenwerkingsverband-IOH (4). Deze toets bevat casulstiek op een breed terrein van de huisartsgeneeskunde en is geschoeid op de leest van de in dit proefschrift beschreven diabeteskennistoetsen. Tot op heden werd driemaal, namelijk in juni 1988, in juni 1989 en februari 1990, een deel van de casuistiek uit de diabetestoetsen als onderdeel van een volledige toets gebruikt. De toetsen als geheel bestonden steeds uit 150 vragen, van het zelfde type als gebruikt in dit onderzoek. In de drie landelijke kennistoetsen van het Samenwerkingsverband- $\mathrm{IOH}$ waren steeds 20 vragen (in de vorm van drie of vier casus) opgenomen, die afkomstig waren uit toets 1 of toets 2, zoals die ontwikkeld zijn binnen dit onderzoek.

De goedscores op deze toets, tenminste de deelscores op het onderdeel diabetes, zijn te beschouwen als een voortzetting van het in dit proefschrift beschreven onderzoek. Ze zijn daarom van belang omdat ze een uitspraak mogelijk maken over de bruikbaarheid van de ontwikkelde diabetestoetsen op langere termijn. Daarnaast is vergelijking van de scores met die van de "lichting" 1985-1986 (zoals onderzocht in dit proefschrift) zeer interessant. In tabel 22. worden de resultaten gepresenteerd.

Tabel 22 Scores per afname in percentage goed beantwoorde diabetesvragen, SD, totale goedscore hele toets en SD hele toets

\begin{tabular}{|c|c|c|c|c|c|}
\hline $\begin{array}{c}\text { ujdstip } \\
\text { afname }\end{array}$ & $\begin{array}{c}\text { aantal } \\
\text { deelnemers }\end{array}$ & $\begin{array}{c}\text { \% goed beantwoorde } \\
\text { diabetesvragen } \\
(\mathrm{N}=20)\end{array}$ & SD & $\begin{array}{c}\text { tot. goedscore } \\
\text { hele toets } \\
(\mathrm{N}=150)\end{array}$ & $\begin{array}{c}\text { SD } \\
\text { hele toets }\end{array}$ \\
\hline juni 1988 & 242 & 62 & 12,2 & 66 & 7,5 \\
juni 1989 & 269 & 75 & 11,0 & 70 & 7,3 \\
feb. 1990 & 360 & 69 & 12,2 & 70 & 8,3 \\
\hline toets 1 & 219 & 60 & 8,7 & & \\
\hline toets 2 & 191 & 70 & 8,1 & \\
\hline
\end{tabular}

De verkregen goedscores op deze experimentele landelijke kennistoetsen van het Samenwerkingsverband- $1 \mathrm{OH}$ liggen in dezelfde orde van grootte als die op de diabetestoetsen.

Alleen de score van juni 1989 ligt wat hoger, alhoewel niet buiten de range, die de aizonderlijke: instituten in ons eigen onderzoek bestrijken.

Deze scores zijn een aanduiding, dat de ontwikkelde diabeteskennistoets bruikbaar is voor de. 
bedoelde populatie en dat ze ook in de tweejarige beroepsopleiding tot huisarts kunnen worden ingezet. Deze resultaten geven een onderbouwing aan de praktische bruikbaarheid van de binnen dit onderzoek ontwikkelde diabeteskennistoetsen.

Ook de vergelijking van de resultaten van de diabetestoets met die van de landelijke kennistoets is niet zonder meer rechtstreeks mogelijk. Het belang van de vergelijking ligt veel meer in het bezien of de resuitaten zoals verkregen van een zelfde soort deelnemers (huisartsen-inopleiding) in dezelfde orde van grootte liggen.

\subsubsection{Groei per rubriek diabetestoets}

Wanneer we de gegevens over de 10 rubrieken bestuderen, blijkt de groel in kennis niet op een vergelijkbare manier bij alle rubrieken plaats te vinden (zie tabel 21).

Rubriek 5 (diagnostiek van diabetes), rubriek 7 (medicatie, overige therapie en beleid bij type II), rubriek 8 (dieet) en rubriek 10 (diversen) springen er duidelijk boven uit (rubriek 4 . pathofysiologie - wordt niet besproken gezien het geringe aantal vragen, het verschil in aantal vragen per toets en de zeer grote SD).

Ook rubriek 6 (diagnostiek van complicaties) laat een sterke groei zien, evenals rubriek 3 (epidemiologie en erfelijkheid).

Dit wijst erop dat de groei in kennis optreedt juist in die kennisgebieden, die naar mijn mening voor de huisarts het meest belangrijk zijn bij zijn/haar zorg voor de type II diabetespatienten in de eerste lijn. Dit zijn aanwijzigingen die wijzen in de richting van de veronderstelling dat de énjarige beroepsopleiding tot huisarts de deelnemers redelijk goed voorbereidde om te voldoen aan de specifieke eisen die de latere beroepsuitoefening aan hen stelt op het terrein van de diabeteszorg.

\subsection{Vergelijking met ervaren huisartsen}

Wanneer gekeken wordt naar de resultaten van de ervaren huisartsen op toets 1 , zoals beschreven in hoofdstuk 7, doet zich nu de vraag voor hoe deze zich verhouden tot de scores van de huisartsen-in-opleiding.

In tabel 23 worden de gemiddelde goedscores van de huisartsen-in-opleiding op toets 1 en toets 2 naast de gemiddelde goedscores van de ervaren huisartsen gepresenteerd. Aangetekend moet worden dat de beide bestanden van huisartsen-in-opleiding niet dezelfde zijn als die welke gebruikt zijn in hoofdstuk 5. In dit hoofdstuk werden namelijk 219 huisartsen-in-opleiding aan het begin van de beroepsopleiding onderzocht.

Hier gaat het immers om een selectie van 131 deelnemers, die zowel aan toets 1 als aan wets 2 deelnamen. Ook de rubriekscores zijn. niet precies dezelfde als die welke gebruikt zijn in de hoofdstukken 5 en 6 . Het bestand ervaren huisartsen is niet veranderd. 
Tabel 23 Gemiddelde goedscores huisartsen-in-opleiding toets 1 en 2 van het longitudinale bestand met de goedscores, zoals die op de transversale meting (zie de hoofdstukken $5 \mathrm{en} \mathrm{6)} \mathrm{zijn} \mathrm{gevonden.} \mathrm{en}$ gemiddelde goedscores ervaren huisartsen toets 1 per rubriek

\begin{tabular}{|c|c|c|c|c|c|c|}
\hline \multirow{2}{*}{ Rubriek } & \multirow{2}{*}{ Onderwerp } & \multicolumn{2}{|c|}{$\begin{array}{l}\text { Huisartsen in opl. } \\
\text { toets } 1 \text { trans. }\end{array}$} & \multicolumn{2}{|c|}{$\begin{array}{l}\text { Huisartsen in opl. } \\
\text { ioets } 2 \text { trans. }\end{array}$} & \multirow{2}{*}{\begin{tabular}{|c}
$\begin{array}{c}\text { Ervaren huisartsen } \\
\text { toets } 1\end{array}$ \\
80,8
\end{tabular}} \\
\hline & & 79.9 & 80,5 & 73,0 & 778 & \\
\hline 2 & niet acuut type i & 575 & 58,7 & 64,3 & 64,2 & 74,2 \\
\hline 3 & epidemiologie, erfelijkheid & 60,9 & 58,8 & 683 & 675 & 64,0 \\
\hline 4 & pathofysiologie & 718 & 68,5 & 83,2 & 79.6 & 58,0 \\
\hline 5 & diagnostiek & 68,2 & 65,7 & 79.8 & 79.3 & 71,1 \\
\hline 6 & complicaties & 63,9 & 63,2 & 71,3 & 70,6 & 66,0 \\
\hline 7 & medicatie & 49.9 & 48,6 & 68,1 & 68,0 & 59,0 \\
\hline 8 & dicet & 44,3 & 41,6 & 60,3 & 60,4 & 50,2 \\
\hline 9 & psychosociaal $\&$ financied & 57,6 & 53.5 & 60,8 & 648 & 69,0 \\
\hline 10 & diversen & 51,3 & 50,7 & 64,9 & 63,3 & 645 \\
\hline Tot & & 61,2 & 60,1 & 70,8 & 69.6 & 66,7 \\
\hline
\end{tabular}

Bij het bekijken van de rubriekscores vallen twee verschijnselen direct op. De ervaren huisartsen blijken een duidelijk hogere score te hebben op de beide rubrieken, die betrekking hebben op type 1 diabetes. Dit geldt bij vergelijking met de rubriekscores voor zowel de eerste als de tweede afname bij de collegae in opleiding.

Vervolgens blijken de ervaren huisartsen voorbij gestreefd te worden gedurende de beroepsopleiding door de huisartsen-in-opleiding op de rubrieken $5,6,7$ en 8 . Liggen de resultaten bij de eerste afname nog wat lager, bij de tweede afname zijn ze duidelijk hoger dan die van de practici. Deze rubrieken zijn te beschouwen als de kern van de diabeteszorgverlening in de huisartspraktijk.

De groep ervaren huisartsen is merendeels langer dan 10 jaar gevestigd, $94 \%$ langer dan 5 jaar. Uit dit onderzoek blijkt dat ervaring alleen geen garantie voor een adequaat kennisniveau vormt.

Hierbij moet direct worden aangetekend, dat in de jaren tachtig vee! is veranderd op het terrein van de zorg voor type li diabetespatiēnten. Het beleid is een stuk agressiever geworden en ook de opsporing en behandeling van complicaties heeft een enorme ontwikkeling doorgemaakt. Te denken valt aan de verandering van de diagnostische classificatie van bloedsuikerwaarden, vaatchirurgische en hartchirurgische behandeling van complicaties op het hart- en vaatstelsel, de oogheelkundige lasertherapie van diabetische retina aandoeningen en ingrijpende wijzigingen in de inzichten in voeding, dieet en insulinebehandeling bij diabetes mellitus.

De tijd van het therapeutisch nihilisme, vanuit het idee, dat een beetje suiker op de oude dag weinig kwaad kan, is bij de toonaangevende medici - in dit geval de internist-endocrinologen en de huisartsen met expertise op het gebied van de diabeteszorg - inmiddels verdwenen.

Mogelijk zijn de huisartsen-in-opleiding bij de behandeling van diabetespatiênten in de praktijk dermate worden aangezet tot kennisverwerving door de vlucht die de behandeling van type II diabetes inmiddels heeft genomen, dat het forse verschil tussen de scores op toets 1 en toets 2 met name in de rubrieken 5 tot en met 8 hieruit valt te verklaren.

Ook de totale gemiddelde goedscore ligt met $70 \%$ iets boven de $67 \%$, die de groep ervaren huisartsen behaalde. Dit is een verschil dat terugvertaald naar het scoringstraject van de MVT overeenkomt met een studieperiode van 4 - 6 maanden. 


\section{Literatuur bij hoofdstuk 9}

1. Verwijnen G, Fróberg C. Jaarverslag over het academisch jaar 1984-85 van de voortgangstoetsbeoordelingscommissie. PES Bulletin no 117. Maastricht: Rijksuniversiteit Limburg, 1986.

2. Bulte J, Van der Ende J, Grol R, Groenier K, Helsper A, Mokkink H, Tielens V, Visser S. De Beroepsopleiding tot Huisarts. Evaluatie van op de preventieve taak van de huisarts gerichte onderwijsprogrammas. Groningen/Nijmegen, 1988.

3. Bulte J, Verwijnen GM, Tielens V, Van Leeuwen YD. Groei in kennis tijdens de Nijmeegse huisartsopleiding gemeten met de MVT. In: Bulte J ea. De Beroepsopleiding tot Huisarts. Groningen/Nijmegen, 1988.

4. Pollemans MC, Eekhof JAH, Kramer AWM, Van Leeuwen YD. Kennistoetsing bij aanstaande huisartsen. Bulletin Medisch Onderwijs 1991; 10: 76-80. 


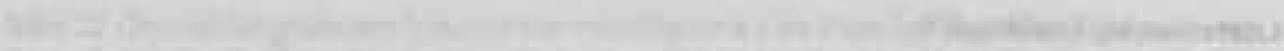

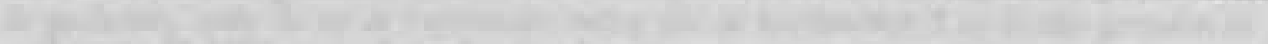

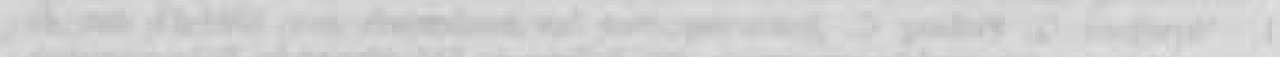

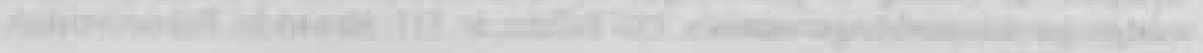

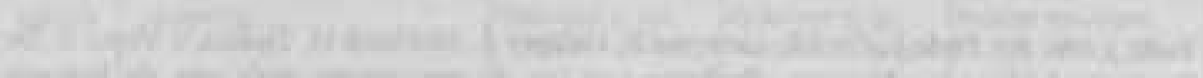

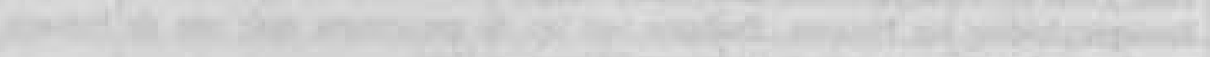
and

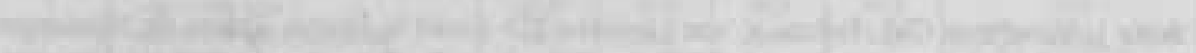

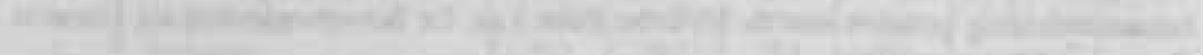

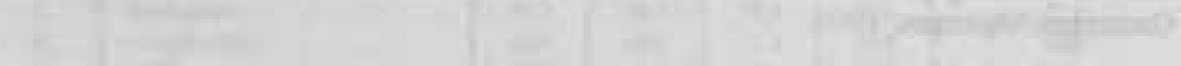

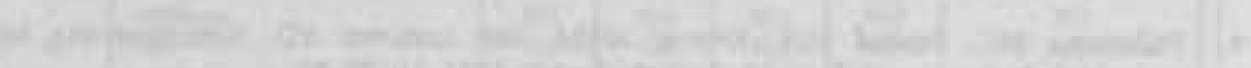

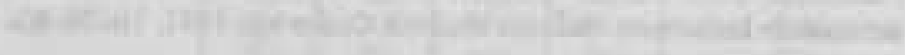

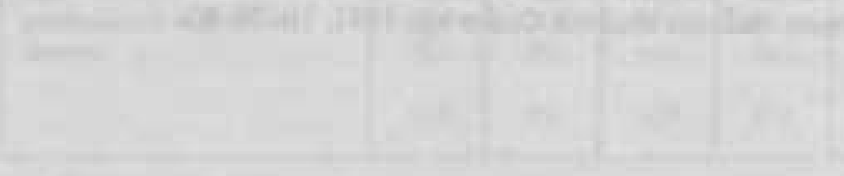




\section{Hoofdstuk 10}

\section{Conclusies}

In dit hoofdstuk zal uitgaand van de vraagstellingen, zoals geformuleerd in hoofdstuk 2, bezien worden in hoeverre deze met gebruikmaking van het uit het onderzoek verkregen materiaal zijn. te beantwoorden.

Tevens zullen suggesties voor nader onderzoek gedaan worden.

\subsection{De onderzoeksvraagstellingen}

De eerste vraagstelling luidde:

\section{Is het mogelijk om effecten van een opleidingsprogramma tot huisarts op een verantwoorde wijze} te beschrijven.

Zoals in hoofdstuk 2 werd beschreven is er om een aantal uiteenlopende redenen voor gekozen deze vraag niet in zijn algemeenheid te beantwoorden, maar om een exemplarische benadering te kiezen. Er wordt dan verondersteld, dat de gevonden resultaten in principe ook bij andere soortgelijke onderwerpen kunnen worden gevonden. Het kiezen voor deze benadering had tot gevolg dat de vraagstelling beperkt werd tot het trachten vast te stellen van de effecten van een opleidingsprogramma tot huisarts op het onderwerp 'kennis over diabetes mellitus'. Binnen dit onderzoek is geen poging gedaan om aan te tonen dat de gekozen beperking van de eerste vraagstelling toelaatbaar is, in de zin dat gevonden resultaten inderdaad generaliseerbaar zijn. Echter, de zorg voor patienten met diabetes. mellitus vertoont veel overeenkomsten met de zorg voor patiénten met bijvoorbeeld CARA, hypertensie, hart- en vaatziekten of arthrose - allemaal in de huisartspraktijk veel voorkomende chronische aandoeningen. Elke aandoening vereist natuurlijk specifieke medische kennis van de huisarts, maar de kaders waarbinnen en de wijze waarop de zorg verleend wordt lijken erg veel op elkaar zoals hieronder uiteen gezet wordt.

$\mathrm{Na}$ een diagnostische fase en een fase waarin naar optimale therapie en begelleiding wordt gezocht, kenmerkt de zorg voor patiẻnten met chronische aandoeningen zich door een relatief langdurige stabiele fase waarin de patiènt regelmatig ter controle gezien wordt en er gelegenheid is om de patiênt zo goed mogelijk met de beperkingen die de aandoening met zich meebrengt te leren omgaan. Later in het ziekteproces is er vaak sprake van complicaties en/of extra invaliditeit door het optreden of verergeren van bijkomende: ziekten.

Steeds geldt dat bij de zorg voor patiênten met een chronische aandoening zowel medische aspecten als begeleidingsaspecten aan de orde zijn. Mogelijk zijn zelfs de begeleidingsaspecten bij deze diverse chronische aandoeningen van minstens evenveel gewicht voor de uiteindelijke kwaliteit van de geleverde zorg als de specifiek medische aspecten. Her zijn juist die begeleidingsaspecten die bij de diverse chronische aandoeningen zoveel op elkaar lijken.

Het is daarom dat wij menen te mogen aannemen dat de bevindingen uit dit onderzoek, met name ten aanzien van de rubrieken over niet acute zorgverlening bij diabetespatienten, ook bruikbaar zijn voor soortgelijk onderzoek naar andere chronische aandoeningen en in die zin als exemplarisch kunnen worden beschouwd.

Zoals in hoofdstuk 2 uiteengezet is, werd besloten tot het formuleren van een aantal tussenstappen in de vraagstelling.

De eerste tussenstap had tot doel om te komen tot een normatieve kennisbeschrij.ving van het te onderzoeken terrein en luidde in de vorm van een vraagstelling: 
2. Welhe hennis over diagnostiek en behandeling van patienten met diabetes mellitus dient een huisarts aan het einde van de beroepsopleiding te hebben verworven?

Hetgeen huisartsen aan het eind van de beroepsopleiding dienen te weten, werd uitgeschreven in het Kennispakket voor de behandeling van diabetes mellitus in de huisartspraktijk (bijlage 1). Daarbij werd gebruik gemaakt van literatuurstudie, praktijkervaring en gesprekken met behandelaars van diabetespatienten, werkzaam in zowel eerste als tweede lijn.

Zes huisartsexperts, vormden een expertpanel, dat het concept van het Kennispakket op relevantie voor de huisartspraktijk en volledigheid beoordeelde.

Het door het panel geleverde commentaar (zie hoofdstuk 4) werd in de uiteindelijke versie van het Kennispakket verwerkt.

Het Kennispakket, dat als inhoudelijke basis diende voor de geconstrueerde toetsen, is te beschouwen als een gedetailleerde uitwerking van een onderdeel van het LHV-basistakenpakket van de huisarts, namelijk de zorg voor de oudere, type II, diabetespatient.

Het is nagenoeg volledig congruent met de aanbevelingen van de nu toonaangevende, maar destijds nog niet beschikbare NHG-standaard over diabetes mellitus type 11 .

Daarnaast is het Kennispakket onderdeel van het deskundigheidsbevorderingspakket dat bij de NHG-standaard is verschenen.

\section{De derde vraagstelling luidde:}

3. Welke hennis over diagnostiek en behandeling van patienten met diabetes mellitus hebben basisartsen, die aan dé béroepsoplètaing tot huisarts beginnen?

Deze vraagstelling had tot doel om te weten te komen wanneer de betreffende kennis feitelijk werd opgedaan. Aan het begin van de beroepsopleiding blijkt het kennisniveau niet gelijkmatig gespreid te zijn over de 10 door ons onderscheiden rubrieksonderwerpen. De invloed van het basiscurriculum lijkt hierin duidelijk te herkennen. Zoals in Hoofdstuk 5 is beschreven, blijken de huisartsen-in-opleiding bij de start van de huisartsopleiding te beschikken over een goede kennis op het gebied van de zorg voor acuut ontregelde type I diabetespatienten.

Kennis over voor de huisarts belangrijke onderdelen van de diabeteszorg, zoals medicatie, overige therapie en beleid bij type II diabetes (rubriek 7) en dieetbehandeling (rubriek 8), is in veel mindere mate aanwezig. Hierdoor ontstaat een beeld van een wat eenzijdig, klinisch georiênteerd, kennispatroon.

De vierde vraagstelling luidde:

4. We!ke kennis over diagnostiek en behandeling van patienten met diabetes mellitus hebben huisartsen, die de beroepsopleiding tot huisarts afsluiten.

In hoofdstuk 6 wordi deze vraagstelling beantwoord.

In hoeverre het gepresenteerde kennishiveau aan het einde van de beroepsopleiding tot huisarts acceptabel is, is nie! zonder meer aan te geven.

Gaat men eryan uit dat het binnen dit project opgestelde Kennispakket als minimumnorm voor de kennis met betrekking tot diabetes van een aanstaande huisarts moet gelden, dan is theoretisch slechts een goedscore van $100 \%$ voor elke af te leveren huisarts acceptabel. Dit is echter geen gebruikelijke normering.

De gemiddelde eindscore van de onderzochte huisartsen-in-opleiding is $70 \%$.

Uit de antwoordpatronen van de deelnemers aan de tweede afname komt een vrij evenwichtige spreiding van kennis over zowel type I als type II diabetes me!litus naar voren. 
Er zijn geen duidelijk omschreven lacunes in kennis aan te geven. De typische huisartsgeneeskundige kennis, nodig voor het opsporen, begeleiden en behandelen van met name type II diabetespatiênten, blijkt op een redelijk niveau aanwezig te zijn. Alleen kennis over dieetbehandeling zou meer aandacht in het instituutsgebonden onderwijs kunnen krijgen (1). Er bestaat inmiddels een onderwijsprogramma over voeding (2) die in deze lacune voorziet. Uit de antwoordpatronen van de deelnemers aan de tweede afname komt een vrij evenwichtige spreiding van kennis over zowel type I als type II diabetes mellitus naar voren.

Bovendien treedt de groei in kennis bij de onderzochte huisartsen-in-opleiding met name op bij de voor de praktijk meest relevante rubrieken (5, 6, 7 en 8 ). Dit beschouwen wij als een zeer acceptabel eindresultaat van de opleiding. Door het geringe aantal vragen over op zich zeer interessante onderdelen van de zorg voor diabetespatiênten, zoals bijvoorbeeld de oogheelkundige aspecten van de zorg, laat het verzamelde materiaal hierover geen uitspraken toe.

De binnen dit onderzoek verkregen gegevens over de stand van zaken aan het eind van de eenjarige beroepsopleiding, zullen kunnen bijdragen aan een nadere explicitering van het niveau dat acceptabel is voor een huisarts die een meerjarige beroepsopleiding heeft doorlopen.

De groep onderzochte ervaren huisartsen (zie hooldstuk 6) scoort gemiddeld $67 \%$. Dit betekent dat de onderzochte groep huisartsen-in-opleiding binnen de beperkte opleidingsduur van destijds (een jaar) gemiddeld op eenzelfde - of zelfs iets hoger - niveau uitkomt dan de praktizerende huisartsen.

Dit geeft antwoord op de vijfde vraagstelling, die luidde:

5. Wat zijn de verschillen en overeenkomsten tussen recent opgeleide huisartsen en ervaren huisartsen op het gebied van hennis over diagnostiek en behandeling van patienten met diabetes mellitus ?

De zesde vraagstelling luidde:

6. Wat zijn verschillen en overeenhomsten in kennis van deelnemers geaggregeerd op instituutsniveau?

De verschillen in kennis uitgedrukt in goedscores tussen de instituten zijn niet groot.

Helaas bleek nauwelijks meer te achterhalen, welk diabetesprogramma men precies had gevolgd op het instituut. In ieder geval zijn dit steeds programmals van enkele uren geweest. Bij een meer grootschalige opzet van het onderzoek had hier meer aandacht aan besteed kunnen worden.

Wat betreft de zevende vraagstelling:

7. Wat zijn de verschillen en overeenhomsten tussen huisartsen-in-opleiding onderling op het punt van speciale belangstelling voor diabetes mellitus?

Hierbij blijkt uit de antwoorden op de "aanıvullende vragenlijst deelnemers" (bijlage 5) dat er zeer weinig verschil tussen de deelnemers was op de punten, die een mogelijke voorsprong in kennis op het gebied van diabetesbehandeling zouden kunnen verklaren.

Het meten van kennis door middel van een toets die opgebouwd is uit zogenaamde juist/onjuist vragen rond casuistiek uit de huisartspraktijk, blijkt een geschikte methode onn kennis bij huisartsen-in-opleiding te meten.

De geconstrueerde toetsen kennen een relatief korte afnametijd (gemiddeld 3 kwartier per toets), zijn met behulp van de computer verwerkbaair en bieden de mogelijkheid tot snelle 
terugkoppeling, zowel op individueel als op groeps- of instituutsniveau. In dit onderzoek is gebleken dat de in dit project geconstrueerde diabeteskennistoetsen geschikt zijn voor gebruik als evaluatie-instrument in een landelijke kennismeting bij deelnemers aan de beroepsopleiding tot huisarts.

\subsection{Conclusies en aanbevelingen}

De ervaringen binnen het hierboven gerapporteerde onderzoeksproject, wijzen erop dat het mogelijk is om:

- een onderdeel uit het LHV-basistakenpakket van de huisarts inhoudelijk uit te werken in een kennispakket voor (aanstaande) huisartsen

- op basis van een dergelijk kennispakket evaluatie-instrumenten te ontwikkelen, die toepasbaar zijn op landelijke schaal

- met behulp van de ontwikkelde kennistoetsen gegevens te verzamelen op landelijk niveau over het kennisniveau van artsen in opleiding tot huisarts

- daadwerkelijke medewerking te verkrijgen voor landelijke evaluatie-activiteiten van alle acht universitaire huisartsinstituten

- op het gebied van evaluatie van de huisartsopleiding landelijk samen te werken door gebruik te maken van een netwerk van vaste contactpersonen per instituut.

Het in kaart brengen en bewaken van de kwaliteit van de op te leiden Nederlandse huisartsen lijkt hiermee duidelijk tot de reêle mogelijkheden te kunnen worden gerekend.

Inmiddels is door de ontwikkelingen van de laatste jaren met de start van de verlengde beroepsopleiding en het Samenwerkingsverband $\mathrm{IOH}$ te Utrecht een groot deel van dit traject in gang gezet. Dergelijke ontwikkelingen in de beroepsopleiding zullen ongetwijfeld een uitstraling hebben op de situatie van de beroepsgroep. Te denken valt hierbij bijvoorbeeld aan veranderingen op het gebied van herregistratie.

Een volgende stap in dit soort onderzoeken zou kunnen zijn om na te gaan of het mogelijk is om gesignaleerde tekorten middels gerichte aandacht in het onderwijs tijdens de terugkomdagen op de instituten of middels aanvullende stages weg te werken.

Op het gebied van diabetesbehandeling is het hiervoor benodigde materiaal in de vorm van het Kennispakket en twee kennistoetsen in dit project ontwikkeld.

Uitgaande van de door de NHG ontwikkelde standaardenreeks zal het in samenwerking met het Samenwerkingsverband $\mathrm{IOH}$ vij eenvoudig zijn om een reeks verschillende onderwerpen onder de loupe te nemen. Hierbij moet dan met name gedacht worden aan andere chronische aandoeningen.

Nader onderzoek naar competentie van huisartsen-in-opleiding en huisartsen zal meerdere aspecten tot onderwerp moeten hebben, die in dit onderzoek gezien de bescheiden schaal en opzet niet aan bod zijn gekomen. Te denken valt hierbij aan communicatieve en medischtechnische vaardigheden.

\section{Literatuur bij hoofdstuk 10}

1. Zuidweg J, Jacobs P. Huisartsen en diabetesdieet. Nederlands Tijdschrift voor dietisten $1988 ; 43: 5$ 
2. Buys G, Almekinders F. Onderwijsprogramma Voeding. Utrecht: RU Utrecht/Stichting Voeding Nederland, 1988 


\section{Samenvatting}

Dit proefschrift beschrijft de ontwikkeling van twee kennistoetsen, met als onderwerp de zongverlening van de huisarts aan patienten met diabetes mellitus. Het kennisdomein zorgverlening aan patiênten met diabetes mellitus in de huisartspraktijk werd uitgeschreven in een zogenoemd Kennispakket voor de behandeling van diabetes mellitus in de huisartspraktijk. De toetsen bestaan uit een serie korte situatieschetsen van een patièntenprobleem- afgeleid uit het Kennispakket-steeds gevolgd door en aantal vragen van het juist/onjuist type. De beide toetsen werden in 1985-1986 afgenomen bij ongeveer 400 deelnemers aan elk van de acht Nederlandse beroepsopleidingen tot huisarts en bij een groep praktizerende huisartsen. Naast rapportage over de validering en betrouwbaarheid worden de scores van de deelnemers besproken. Bij het vergelijken van beginnende huisartsen in opleiding met hen die bijna aan het eind van hun huisartsenjaar stonden, is er groei in kennis gevonden op de gebieden diagnostiek, diéetbehandeling en medicatie bij niet van insuline afhankelijke diabetespatiènten.

In hoofdstuk 1 wordt een korte schets van het kader gegeven waarin de beroepsopleiding tot huisarts in Nederland plaatsvindt. De omstandigheden die geleid hebben tot de start van dit onderzoek komen aan de orde.

Hoofdstuk 2 beschrijft een zevental vraagstellingen en geeft een verantwoording van de gebruikte onderzoeksmethode, te weten kennismeting door constructie en afname van toetsen en panel-onderzoek naar de consensus van de geldigheid van de kennisdomeinomschrijving. namelijk het Kennispakket voor de behandeling van diabetes mellitus in de huisartspraktijk.

Hoofdstuk 3 bespreekt de positie van de huisarts in de zorg voor patienten met diabetes mellitus , met name voor de groep, die niet van insuline afhankelijk is. Het Kennispakket wordt vergeleken met de gezaghebbende Europese consensus met betrekking tot controle en behandeling van de niet van insuline afhankelijke diabetespatiênten, opgesteld door de de EURNIDDM- Policy Group.

In hoodstuk 4 worden problemen bij het meten van kennis door middel van toetsafname besproken en wordt gedetailleerd ingegaan op de verdeling van de geconstrueerde vragen over de 17 casus in toets 1 en toets 2. Validiteitsaspecten bij kennistoetsing worden besproken evenals de procedure, die werd gevolgd bij het tot stand komen van het kennispakket. Na het opstellen van een concept werd een groep specialisten op diverse vakgebieden geraadpleegd en vervolgens werd het eindprodukt voorgelegd aan een panel van gezaghebbende huisartsen met de vraag naar de relevantie van de inhoud voor de zorg aan patiênten met diabetes mellitus type II. Deze vraag werd door hen positief beantwoord. Aspecten van betrouwbaarheid die aan de. orde komen, zijn herhaalde toetsafname via paralleltests en itemanalyse.

In hoofdstuk 5 en 6 wordt gerapporteerd over de afname van respectievelijk toets 1 bij 219 huisartsen-in-opleiding aan het begin van hun opleidingsjaar en toets 2 bij 191 huisartsen-inopleiding, die bijna door hun opleidingstijd heen zijn. De gemiddelde score voor de 'beginners" bedraagt $60 \%$ goed beantwoorde vragen, de tweede groep scoort $70 \%$ goed. Verschillen tussen beide groepen worden besproken.

In hoofdstuk 7 wordt verslag gedaan van de afname van toets 1 bij 62 ervaren huisartseri. $\mathrm{Zij}$ scoren als groep hoger dan de 'beginners', namelijk $67 \%$ van de vragen wordt goed beantwoord. 
In hoofdstuk 8 wordt bezien in hoeverre de scores van toets 1 rechtstreeks met die van toets 2 kunnen worden vergeleken. Besloten werd om een nieuwe toets te construeren, bestaande uit delen van toets 1 en 2 . Deze toets 3 werd vervolgens bij een groep van 58 huisartsen in opleiding, die halverwege het opleidingsjaar waren, afgenomen. Op deze manier zijn uitspraken mogelijk over de relatieve moeilijkheidsgraad van toets 1 vergeleken met toets 2 . De gemiddelde goedscore op toets 3 bedroeg $61 \%$. Uit dit betrouwbaarheidsexperiment kan geconcludeerd worden, dat toets 1 en toets 2 niet of nauwelijks in moeilijkheid verschillen en dat een toename in percentage goed beantwoorde vragen zeer waarschijnlijk kan worden toegeschreven worden aan een groei in kennis.

Hoofdstuk 9 bespreekt de groei in kennis gedurende beroepsopleiding tot huisarts. Er blijkt een meetbare groei in kennis op te treden voor elk van de deelnemende instituten, waarbij deze voor viff van de zeven bij deze analyse betrokken instituten significant is.

In hoofdstuk 10 worden conclusies getrokken Door middel van uitwerking van een bepaald belangrijk onderdeel van de huisartsgeneeskunde in een nauwkeurige kennisdomeinbeschrijving, blijkt het mogelijk bruikbare kennistoetsen te construeren. Het blijkt mogelijk middels deze kennistoetsen om op landelijke schaal kennismetingen te verrichten binnen de beroepsopleiding tot huisarts. Daarnaast worden aanbevelingen voor verder onderzoek gedaan. 


\section{Summary}

This thesis provides a description of the developments of two formative assessment tests based on the subject: The care received by diabetic patients from their general practitioners. The discipline of 'Care of patients with diabetes mellitus in general practice' was documented in a supposed information package for the treatment of diabetes mellitus in family practice.

The existence of the tests are a result of a series of patient profiles derived from the information package and followed with a number of yes/no type questions. Both of these tests were conducted in 1985 and 1986, and were made up of some 400 participants from each of the eight Dutch vocational training schools and a group of general practitioners. Together with reports concerning validation and reliablity, the scores were discussed with the participants.

A comparison of residents at the beginning of their training year with residents about to complete their one year residency, showed increased knowledge in the areas of diagnostic skills, diet, treatment and medication of non-insuline dependent diabetics.

Chapter 1 provides a brief outline of how the Dutch education system of residency in family medicine is organised and the circumstances that led to the commencement of this research.

In chapter 2, seven pertinent questions are asked that provide justification for the research methods used: measuring knowledge by the composition of and undertaking of tests and panel research, to the consensus of the validity of the disciplines described, namely, the information package for the treatment of diabetes mellitus in family practice.

Chapter 3 discusses the position of the general practitioner in the care of patients with diabetes mellitus, especially for the non-insuline dependent group. The information package is compared with the influential European consensus according to control and treatment of the non-insuline dependent diabetic patients, formulated through the EUR-NIDDM policy group.

Chapter 4 deals with problems by measuring knowledge by means of a test where detailed information is presented concerning the division of the assembled questions of some 17 individual cases in tests 1 and 2. Validity aspects of knowledge testing are discussed, followed by the procedure that was used to assemble the information package. Once the framework of the concept was put together, a group of specialists from various disciplines were consulted. Once this had been completed the final product was then presented to a panel of influential general practitioners with the question, "How relevant are the contents for the care of patients suffering from diabetes mellitus type II?". This question was met with a positive response. Aspects of reliability mentioned are repeated testing via parallel tests and item analysis.

Chapters 5 and 6 discuss the results of tests 1 and 2 respectively. Test 1 was comprised of 219 residents at the onset of their training year and test 2 was comprised of 191 residents who were almost at the finish of their training. The average score for the 'beginners' totalled $60 \%$ good answers to the questions, while the second group scored $70 \%$ good. The differences between both groups are discussed here.

Chapter 7 discusses the results of 62 experienced general practitioners that participated in test 1. They scored higher than the 'beginners', namely, $67 \%$ replied good to the questions.

Chapter 8 demonstrates how far the scores from test 1 can be compared with those from test 2 . A new test was put together by using portions from both tests 1 and 2 . This third test was 
comprised of 58 residents in family medicine when they were about half-way through their training year. This allowed the possibility to relay some information about the relative degree of difficulty faced when comparing test 1 with test 2 . The average good score of test 3 was about $61 \%$.

From this reliability test, it can be concluded that tests 1 and 2 do not differ in difficulty and that the growth in percentage of good answers can be attributed to an increase of knowledge.

Chapter 9 discusses the increase of knowledge that appears during the professional training period of general practitioners. There is a measurable increase of knowledge from the competing institutes. In five of the seven competing institutes, growth was significant.

Chapter 10 presents and discusses the conclusions. By working out a specific, relevant part of general practitioner health care in a specific discipline, it is possible to construct functional comprehension tests. It is possible to utilize these tests to adequately measure knowledge on a national scale with the professional education of general practitioners. Also included in this chapter are the proposals for further research. 


\section{Bijlage 1}

\section{Landelijke toets diabetes in de huisartspraktijk}

Voor arts-assistenten in de beroepsopleiding tot huisarts 


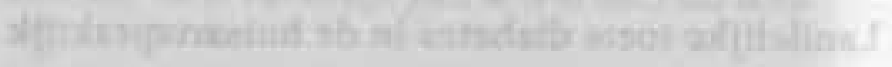

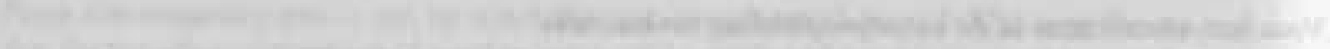

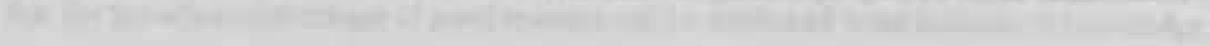

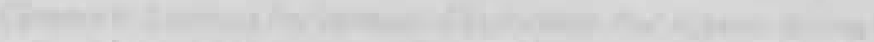

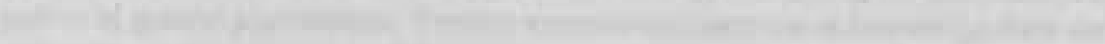

(20)

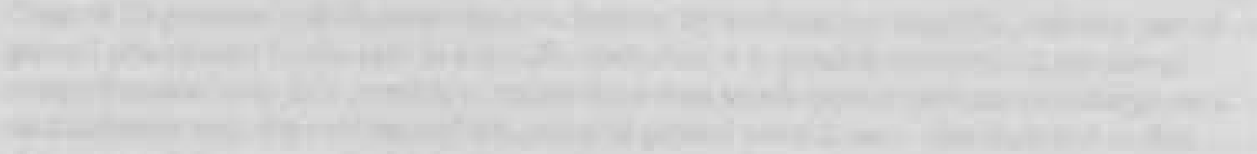

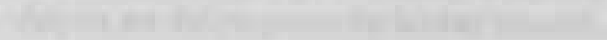


In deze toets worden zeventien patienten voorgesteld die contact hebben met hun huisarts over klachten en problemen rondom diabetes. Over deze klachten en problemen en ook over de handelwijze van de huisarts worden vragen gesteld.

N.B.: de opgevoerde huisartsen gaan niet altijd volgens "het boekje" te werk.

De in de toets gehanteerde indeling van Diabetes Mellitus is:

- Type I = insuline afhankelijke Diabetes Mellitus: IDDM

- Type II = niet insuline afhankelijke Diabetes Mellitus: NIDDM

De toets bevat 126 vragen (er moeten dus 126 antwoorden worden gegeven). In de tekst wordt elke vraag voorafgegaan door een nummer en twee streepjes -

De vragen staan in de vorm van een bewering. Tekst tussen haakjes is bedoeld als aanvullende informatie, deze is steeds correct en behoeft niet beoordeeld te worden.

Los van de toets worden acht aanvullende vragen gesteld (bijlage).

Bij de beantwoording van de vragen kun je kiezen tussen drie mogelijkheden JUIST / ?/ ONJUIST.

Jouw antwoord op een vraag noteer je als volgt op het bijgevoegde antwoordformulier.

Negeer de kolom ponscode.

De cijfers in de kolom vraagnr. corresponderen met de nummers van de vragen.

Omcirkel daarvan het gekozen antwoord.

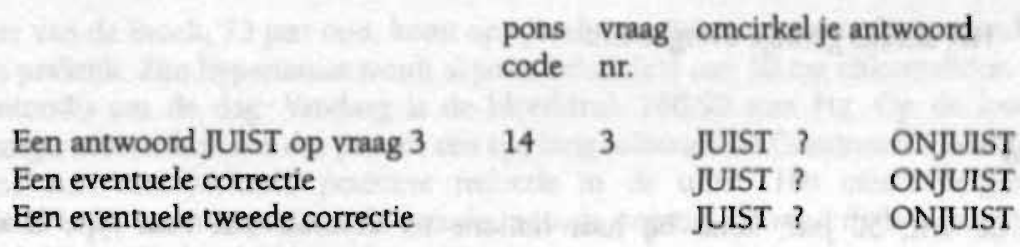

Het maken van de toets neemt ongeveer eén uur in beslag. Na afloop lever je het antwoordformulier in + de ingevulde bijlage. Beide moeten voorzien zijn van je naam en de naam van het huisartsinstituut waar je de beroepsopleiding tot huisarts volgt. Dit laatste is nodig in verband met de terugrapportage van de resultaten (zie Rapportage resultaten). Het rode boekje met de vragen kun je behouden.

\section{Rapportage resultaten}

Elke deelnemer/deelneemster aan de Diabetes-toets krijgt binnen twee maanden na afname van de toets een overzicht van de eigen resultaten en van de gemiddelde groepsresultaten met de gehanteerde sieutel.

De resultaten worden weergegeven in het percentage GOED / ? / FOUT-antwoorden per rubriek (Diagnostiek IDDM/Beleid/Voorlichting e.d.) en over de toets in zijn geheel.

Daar een arts-assistent aan het begin van de beroepsopleiding tot huisarts een aantal zaken nog niet kan weten/beheersen is het goed denkbaar dat bij de eerste afname veelvuldig gebruik gemaakt wordt van het antwoord "?". Een tweede afname volgt aan het eind van de beroepsopleiding.

Een beoordeling van de resultaten in de zin van voldoende/onvoldoende wordt niet gegeven omdat een norm hiervoor niet is vastgesteld. Deelname aan de toets heeft dus geen 


\section{Casus 1}

De heer Vogels, 82 jaar oud, komt op het spreekuur nadat recent bij een rijbewijskeuring glucosurie is geconstateerd. Hij heeft geen klachten; voelt zich kiplekker. Zijn lengte is $1.78 \mathrm{~m}$, gewicht 83 kilo.

De huisarts onderzoekt urine en bloed.

Glucosurie ++ ketonen: negatief. Bloedsuiker twee uur na de maaltijd $12 \mathrm{mmol} / \mathrm{L}$.

De huisarts legt patiént uit dat hij "ouderdomssuiker" heeft. Hij legt patiênt uit dat er niets aan hoeft te gebeuren; dat hij alleen om het half jaar even op controle moet komen en de suikerpot in het vervolg moet laten staan.

Voor de handelwijze van deze huisarts pleit/pleiten:
1. - De leeftijd van de heer Vogels
2. - De afwezigheid van klachten
3. - De bloedsuikerwaarde
4. - Het slechts geringe overgewicht

\section{Casus 2}

Mevrouw de Wit, 50 jaar, komt bij haar huisarts ter controle van haar type II diabetes (NIDDM). Sinds drie jaar is zij bekend met diabetes. Zij is ingesteld met een dieet. Dit keer staat het jaarlijks onderzoek naar mogelijke complicaties van de diabetes op het programma. De huisarts begint het onderzoek met het nalopen van mogelijke uitingen van diabetische neuropathie.

5. - Het testen van de sensibiliteit is in dit kader zinvoller dan het testen van de coordinatie

6. - Het onderzoek van de nervus III-IV en VI (oculomotorius, trochlearis en abducens) is in dit kader zinvoller dan het onderzoek van de nervus V-VII en VII (trigeminus, facialis en vestibulo-cochlearis)

7. - Het letten op atrofie van de kleine handspieren is zinvoller dan het letten op atrofie van de voetspieren

8. - Het testen van de buikhuidreflex is zinvoller dan het letten op trofische storingen van de huid

9. - Een afwezige APR is kenmerkend voor een diabetische neuropathie

Vervolgens wordt gekeken naar met diabetes samenhangende complicaties op oogheelkundig gebied. 
10. - Voor het krijgen van een overzicht van het retinale vaatbed is het gebruik van de directe fundus-scoop meer geschikt dan gebruik van de indirecte fundus-scoop

11. - Het testen van de visus op zes meter afstand is zinvoller dan het testen van het diepte zien

12. - Het testen van de gezichtsvelden geeft een indruk van de uitgebreidheid van een eventuele diabetische retinopathie

De huisarts meet de oogboldruk.

13. - Dit is zinvol omdat diabetes-patiènten een verhoogd risico hebben op glaucoom

Dan wordt gekeken naar complicaties van diabetes op het gebied van het perifere vaatstelsel.

14. - Het onderzoek van de a.femoralis (palpatie + auscultatie) levert in dit verband geen relevante informatie op

15. - Een blauw-rode verkleuring van de voeten (bij afhangende benen) wijst op een perifere circulatiestoornis

\section{Casus 3}

De heer van de Broek, 73 jaar oud, komt op spreekuur voor tensiecontrole, komend vanuit een andere praktijk. Zijn hypertensie wordt al jaren behandeld met $50 \mathrm{mg}$ chloortalidon

(Hygroton(0) om de dag. Vandaag is de bloeddruk 160/90 mm Hg. Op de kaart van zijn voorganger ziet de huisarts dat patiênt een tijd lang tolbutanide (Rastinon®) heeft gebruikt, in verband met een herhaald positieve reductie in de urine. Het creatinine-gehalte is 65 micromol/L. Bij een vorige controle was de reductie negatief en werd de behandeling gestaakt. Ook vandaag geeft de stick geen glucosurie aan.

16. - Dit betekent dat patiént op dit moment gén verhoogde bloedsuikerspiegel heeft

Tot de mogelijke oorzaken van het verdwijnen van de eerder bestaande glucosurie behoort:

17. - Het gebruik van chloortalidon

\section{Casus 4}

Mevrouw Werkman, 24 jaar oud, komt, op het spreekuur. Ze is drie weken over tijd en kreeg zojuist het bericht van de assistente dat de zwangerschapstest positief was. Mevrouw is nu gravida II, para 0, abortus I (na 12 weken).

Zij komt nu bij haar huisarts voor een oriênterend gesprek. Ze: vertelt dat haar moeder lijdt aanı suikerziekte. De huisarts weet dat dit een niet insuline afhankelijke diabetes is. Patiénte vraagt zich af of zij hierdoor een verhoogde kans op zwangerschapssuiker heeft.

18. - Patiênte heeft inderdaad een grotere kans op zwangerschapsdiabetes dan iemand zonder deze familie-anamnese

Vervolgens wil ze weten of haar miskraam iets met suikerziekte te maken kan hebben. 
19. Er is inderdaad een verband tussen zwangerschapssuiker en het optreden van spontane abortus

Mevrouw Werkman vraagt nu of het kind van een moeder met zwangerschapssuiker een verhoogde kans op aangeboren afwijkingen heeft.

\section{0. - Dit is correct}

Patiente vertelt dat ze graag thuis wil bevallen, ook in geval van zwangerschapssuiker. De huisarts raadt dit af. Argumenten tegen een thuisbevalling zijn onder andere:

21. - Een verhoogde kans op complicaties bij de bevalling

22. - Kans op hyperglycaemie post partum bij het kind

Patiénte vraagt of een zwangerschapssuiker met tabletten behandeld wordt. De huisarts vertelt haar dat dit mogelijk is als de aandoening niet ernstig is.

\section{3. - Dit is correct}

De huisarts lege uit dat controle op het optreden van zwangerschapssuiker nodig is. Patiente vraagt of dit nu meteen kan. De huisarts zegt dat dit pas in het tweede trimester mogelijk is.

\section{4. - Dit is correct}

25. - Voor het stellen van de diagnose zwangerschapsdiabetes is de kwantitatieve bepaling van de glucosurie in de 24-uurs urine aangewezen

\section{Casus 5}

De heer Bakker, 56 jaar oud, komt ter controle van zijn sinds vier maanden bekende diabetes mellitus (type II, NIDDM) op het diabetesspreekuur van zijn huisarts. Hij is tevens bekend met hyperiensie, waarvoor hij propranolol gebruikt in de vorm van $160 \mathrm{mg}$ Inderal retard (8) per dag. Zijn gewicht is 78 kilo bij een lengte van $1.70 \mathrm{~m}$. Hij is onder behandeling van de diétiste en het afgelopen jaar is hij drie kilo afgevallen. De bloedsuiker is nu $14,5 \mathrm{mmol}$ postprandiaal (was eerder 16 en 13,5) tensie 145/90.

26. - Het is beter orn nu een oraal bloedsuiker verlagend middel toe te voegen dan om verdere gewichtsdaling af te wachten

Tot de factoren die een verdere daling van de bloedsuiker tegengaan behoort:

\section{7. - Het propranololgebruik}

Patient klaagt zijn nood bij de huisarts. Het sexueel verkeer met zijn vrouw is de laatste tijd erg moeizaam geworden, omdat hij geen erectie meer krijgt.

Tot de meest waarschijnlijke oorzaken van de erecriestoornis behoortbehoren:

28. - De diabetes

29. - De propranolol 


\section{Casus 6}

Mevrouw Wagemakers, 65 jaar oud, komt bij haar huisarts met de mededeling dat haar longarts "een beetje suiker" bij haar geconstateerd heeft. Ze wordt al jaren door de longarts behandeld voor CARA. Ze gebruikt $10 \mathrm{mg}$ prednison per dag, 2 dd. $250 \mathrm{mg}$ theofylline (Theolair retard(1) en 4 dd 2 puffs ipratropium bromide (Atrovent(1). Lengte $1.72 \mathrm{~m}$, gewicht 80 kilo.

De longarts heeft haar naar een diêtist gestuurd. Ze kreeg een vetbeperking voorgeschreven. Suiker is haar niet absoluut verboden. Ze snapt er niets van. De huisarts legt haar uit dat een vetbeperking effectiever is om af te vallen dan koolhydraatbeperking.

\section{1. - Dit is correct}

De huisarts legt uit dat het prednisongebruik suikerziekte kan uitlokken.

\section{2. - De reden hiervoor is dat het glucosetransport in het bloed wordt bemoeilijkt}

De huisarts legt vervolgens uit dat een absoluut suikerverbod tegenwoordig niet meer wordt gegeven. Hij zegt: "Als U rekening houdt met het aantal calorieen dat U op een dag mag gebruiken, mag U best af en toe een Marsreep opeten."

33. - Dit advies is conform de huidige inzichten met betrekking tot behandeling van diabetes

Mevrouw Wagemakers laat de dokter een potje sorbitol-tabletten zien. Hoeft ze die dan ook niet te gebruiken? De huisarts raadt haar dit af. Hij vertelt dat dit soort suikervervangende middelen te veel calorieén bevatten.

\section{4. - Dit is correct}

Patient vraagt of bruin brood en rauwkost goed voor haar zijn. De huisarts bevestigt dit.

35. - Di reden hiervoor is dat vezelrijke voeding de resorptie van koolhydraten in het maagdarmkanaal vertraags:

\section{Casus 7}

Mevrouw Tahimala, 51 jaar oud, is dertig jaar geleden uit Indonesiê naar Nederland verhuiscl. Zij is sinds acht jaar bekend met een niet-insuline afhankelijke diabetes. Zij is pas éen jaar in de praktijk, na een verhuizing. Ze gebruikt 's ochtends 2 en 's avonds 1 tablet tolbutamide van 0,5 gram (RastinonQ).

Vandaag is zij op het spreekuur gekomen in verband met klachten van pijn in de schouder. De huisarts besluit tevens de bloedglucosewaarde te bepalen. Deze blijkt $20 \mathrm{mmol}$ te zijn.

Uit het gesprek hierover wordt duidelijk dat ze nog niet eerder is geprikt en verder ock geen informatie heeft over de aandoening. Zij was gewend om elke drie maanden de medicatie te laten verlengen bij de assistente.

36. - In deze fase is het belangrijker om patiênte tot cen regime van driemaandelijkse controles te bewegen dan om haar informatie over de ziekte te geven 
Mevrouw is $149 \mathrm{~m}$ lang en weegt $46 \mathrm{~kg}$. Dit betekent dat ze goed op haar streefgewicht zit.

37. - Een verwijzing naar de diêtiste is in dit geval toch nodig

Patiénte woont alleen. Haar twee dochters komen ieder twee avonden per week 's avonds bij haar eten. Zij kookt dan uitgebreid Indisch.

38. - Dit gegeven wijst erop dat het wenselijk is om eén van de dochters bij de diabetesbehandeling te betrekken

Bij lichamelijk onderzoek blijkt er een gestoorde vibratie-zin aan de voeten te zijn. Beiderzijds is er sprake van een hallux valgus met eeltvorming.

39. - Op grond van deze bevindingen komt patiénte in aanmerking, voor hulp varı een pedicure op kosten van hell ziekenfonds

Verder blijkt dat patiènte slecht ziet; visus $O D=1 / 60$ OS $=0: 4$.

In het geval van Mevrouw Tahimala zal het ziekenfonds de volgende materialen voor zelfcontrole vergoeden.

40. - Urinestrips voor glucose

41. - Bloedsuikerstrips met bijbehorende afleesapparatuur

\section{Casus 8}

De heer Jansen, 50 jaar, komt op het spreekuur met klachten over pijn in beide benen. De pijn zit vooral rond de enkels, tevens heeft hij stijve knieên in de ochtend. Patiênt vertelt verder dat hij last van jeuk heeft over het gehele lichaam zonder dat er iets aan de huid is te zien. Tot slot vertelt de patiént dat de oogarts heeft gezegd dat zijn oogboldruk iets verhoogd is.

Bij lichamelijk onderzoek vallen op: krabeffecten over het lichaam, een iets naar links vergroot hart, een tensie van 130/100 en spreidvoeten. Aan de benen verder geen afwijkingen. Lengte $1.68 \mathrm{~m}$, gewicht 75 kilo.

De huisarts overweegt de diagnose diabetes mellitus al dan niet met complicaties.

Bij deze diagnose pasupassen:

42. - De pijn rond de enkels

43. - De jeuk

44. - De geconstateerde verhoogde oogboldruk

45. - De hartvergroting

46. - De hypertensie

De huisarts laat een orale glucose tolerantie test (OGTT) doen om diabetes aan te tonen of uit te sluiten.

47. - Dit is in dit geval een correcte handelwijze 
Een jaar later.

De heer Jansen komt voor de driemaandelijkse controle van zijn diabetes op het spreckuur. Met behulp van de dietiste is het afgelopen jaar het aanvankelijke overgewicht goed verminderd, zodat het gewicht nu 65 kilo is (was 75 kilo), lengte $1.68 \mathrm{~m}$.

De bloedsuikerwaarden twee uur na de maaltijd bleven rond de $16 \mathrm{mmol}$. schommelen. Patiênt zegt zich vaak moe te voelen. Vandaag is de glucosewaarde twee uur pp $17 \mathrm{mmol}$. Sinds drie maanden gebruikt de heer Jansen 3 dd 5 mg glibenclamide (Daonil@).

48. - Op dit moment is het meer aangewezen om een biguanide preparaat (metformine, G!ucophage(8) aan de medicatie toe te voegen dan om patiènt in te stellen op insuline

De huisarts besluit om 2 dd 0,5 gram metformine (Glucophage@) aan de medicatie toe te voegen.

Een maand later komt de heer Jansen weer voor controle van de instelling. Op de vraag hoe hij zich voelt antwoordt hij: "Ik heb regelmatig een vol gevoel in de buik, wat diarree en een vieze smaak in de mond. De moeheid is wat minder."

Tot de bijwerking van metformine (Glucophage@) behoor/behoren:

49. - Vol gevoel in de buik

50. - Diarree

51. - Misselijkheid

52. - Metaalsmaak

53. - Versterkte bloedsuikerverlaging in combinatie met alcohol

\section{Casus 9}

De heer Konings, een 32-jarige magazijinbediende bij een groothandel in levensmiddelen, sinds een half jaar bekend met insuline afhankelijke diabetes is op zijn werk niet goed geworden. De huisarts wordt gebeld en gaat er direct naar toe. Zij treft hem aan op het kantoortje van zijn baas, wat bleek weggetrokken in een stoel zittend. Patiént maakt een geagiteerde indruk en spreekt met een dikke tong. De huisarts denkt aan een hypoglycaemie. Bij verdenking op hypoglycaemie is het aangewezen de volgende zaken na te vragen:

54. - Hongergevoel

55. - Dorst in de afgelopen tijd

56. - Hoofdpijn

57. - Overmatig transpireren

58. - Harkloppingen

59. - Duizeligheid 
61. - Rugpijn

Patient blijkt inderdaad klachten te melden die passen bij een hypoglycaemie. De huisarts adviseen de heer Konings om een beker Ranja te drinken en twee boterhammen te eten.

62. - Dit advies is correct

Tot de oorzaken van hypoglycaemie bij een insuline afhankelijke diabetespatiènt behoortbehoren:
63. - Het verrichten van meer spierarbeid
64. - Het te weinig insuline gespoten hebben
65. - Het toepassen van een verkeerde spuittechniek
66. - Het overslaan van een maaltijd

\section{Casus 10}

Om 20.00 uur wordt de huisarts van de heer Steensma, 58 jaar oud, gevraagd met spoed te komen. Bij aankomst treft zij patiênt bleek en bezweet aan. Hij heeft geen pijn. Hij vertelt ineens niet goed te zijn geworden. De tensie is $110 / 70 \mathrm{mg} \mathrm{Hg}$, pols 108 aequaal.

Patient is al jaren bekend met type Il diabetes, waarvoor hij met een dieet en 3 dd 0,5 gram tolbutamide (Rastinon@) behandeld wordt. Patiênt heeft die dag normaal gegeten. De heer Steensma is vanmiddag bij de uroloog geweest in verband met recidiverende urineweginfecties. Hij kreeg cotrimoxazol voorgeschreven (o.a. Eusaprim(8).

67. - De kans op een myocardinfarct is voor iemand als de heer Steensma ongeveer twee keer zo hoog dan voor een niet-diabeet.

De huisarts twijfelt tussen de diagnose myocardinfarct en hypoglycaemie.

68. - Het ontbreken van pị̆n op de borst bij een diabetespatiênt met een myocardinfarct kan verklaard worden door diabetische cardiomyopathie

Voor de diagnose hypoglycaemie pleivpleiten:

69. - Het klinische beeld

70. - De combinatie Rastinono - cotrimoxazol

71. - Het tijdstip (20.00 uur)

\section{Casus 11}

De heer Pijnenborg, 48 jaar, komt op het spreekuur van zijn huisarts met het verzoek om zijn bloedsuiker te laten bepalen. Zijn broer is namelijk recent ontdekt als suikerpatiênt. De huisarts 
besluit lab-onderzoek aan te vragen. De bloedsuiker twee uur na een koolhydraatrijke maaltijd blijkt $9,5 \mathrm{mmol} / \mathrm{L}$ te zijn.

Drie dagen later vertelt de huisarts de heer Pijnenborg dat hij geen echte suikerziekte heeft, maar wel de aanleg daartoe.

De huisarts schrijft op zijn kaart: suspect verminderde glucosetolerantie.

\section{2. - Dit is correct}

De heer Pijnenborg heeft op grond van de twee uurs bloedsuikerwaarde na koolhydraatrijke maaltijd (lager dan $11 \mathrm{mmol}$ ):

73. - Hetzelfde risico op hart- en vaatziekten als iemand met normale bloedsuikerwaarden

74. - Een kans van meer dan $50 \%$ op stijgen van de bloedsuikerwaarde tot boven de $11 \mathrm{mmol}$ binnen 10 jaar

\section{Casus 12}

De heer Colenbrander is een 31-jarige man die bij de huisarts bekend is met een fors overgewicht. Hij weegt al jaren 104 kilo bij een lengte van $1.80 \mathrm{~m}$. Hij komt nu op het spreekuur vanwege een enige weken bestaande ontsteking aan de voorhuid. Patiènt heeft verder geen klachten, met name geen dorst en polyurie.

Bij onderzoek ziet de huisarts een etterige balanitis. Hij besluit de urine op suiker na te kijken. Er blijkt een forse glucosurie te zijn, aceton negatief. Een direct bepaalde bloedsuiker is 18 mmol. De huisarts twijfelt tussen de diagnose niet-insuline afhankelijke en insuline afhankelijke diabetes mellitus.

Tegen de diagnose insuline afhankelijke diabetes pleit/pleiten:

75. - Het forse overgewichi

76. - De afwezigheid van aceton in de urine

77. - De bloedsuikerwaarde onder de $20 \mathrm{mmol}$

78. - De afwezigheid van dorst en polyurie

79. - De leeftijd

\section{Casus 13}

De heer Lubbers, een 66-jarige vitale ex-stewart, komt bij zijn huisarts ter controle van zijn reeds twintig jaar bestaande type II diabetes. Hij gebruikt hiervoor enkel een calorie-beperkt dieet. De glucosewaarden 2 uur post-prandiaal waren in het verleden steeds tussen de 9 en 12 mmol. Patiènt is echter een jaar niet meer op controle geweest wegens verblijf bij zijn dochter in de Verenigde Staten. De heer Lubbers presenteert nu spontaan een aantal klachten. Hij heeft last van: duizeligheid, jeuk, tintelingen in beide handen, frequente neusbloedingen en moeilijk op gang komende mictie met nadruppelen. 
Bij de diabetes past/passen:

80. - De duizeligheid

81. - De jeuk

82. - Tintelingen in beide handen

83. - Frequente neusbloedingen

84. - De mictieklachten

Patient vertelt dat hij zich in de Verenige Staten niet goed aan het dieet heeft kunnen houden. Hij is er ook een paar keer ziek geweest. Tweemaal had hij een huidinfectie, waarvoor behandeling met antibiotica nodig was, énmaal een blaasontsteking en éenmaal gordelroos (herpes zoster).

Door de diabetes kan/kunnen verklaard worden:
85. - De huidinfectie
86. - De blaasontsteking
87. - De gordelroos

Patiênt blijkt bij onderzoek vier kilo zwaarder te zijn dan een jaar tevoren. De assistente meldt een positieve reductie in de urine en een bloedglucose van $20 \mathrm{mmol}$ ( 2 uur post prandiaal). De huisarts vertelt de heer Lubbers dat hij, gezien de huidige klachten, de doorgemaakte ziekten en de huidige lab-uitslagen het verstandig vindt orn de internist met spoed bij de behandeling te betrekken.

Hij vertelt dat de internist waarschijnlijk zal overschakelen op insuline-behandeling, omdat een suikerwaarde van 20 munol te hoog is om nog met tabletten te behandelen.

88. - Dit is correct

\section{Casus 14}

Mevrouw Lamers, 64 jaar, komt bij de huisarts op het spreekuur met de klacht van pijn bij het plassen. Zij heeft de afgelopen twee maanden reeds driemaal een unineweginfectie gehad. Ook dit keer blijkt het sediment weer meer dan 10 leucos per gezichtsveld te bevatten. De huisarts besluit de urine nu tevens te onderzoeken op de aanwezigheid van glucose.

89. - De reden hiervoor is dat patienten met recidiverende urineweginfecties vaker een verhoogde nierdrempel voor glucose hebben dan patiénten zonder urineweginfecties

De reductie blijkt + te zijn, aceton negatief. Een direct nadien gemeten bloedsuikerwaarde blijkt 12.2 te zijn (patiènte is niet nuchter).

De huisarts concludeert hieruit dat patiênte lijdt aan diabetes mellitus type II. 
Patiênte en huisarts hebben een uitvoerig gesprek over de geconstateerde ziekte. Patiênte vraagt of zij de suiker van haar moeder geèrfd heeft. Die had het namelijk ook. De huisarts vertelt haar dat het soort van suikerziekte dat zij heeft (type II) niets met erfelijkheid te maken heeft.

\section{1. - Dit is correct.}

Patiènte vraagt of zij haar dieetkosten vergoed kan krijgen. De huisarts vertelt haar dat het ziekenfonds diabetes-dieetkosten vergoedt.

\section{2. - Dit is correct}

\section{Casus 15}

De huisarts van Henk Ritselaar, een 24-jarige student, wordt 's avonds laat gebeld door een vriendin van patient met het bericht dat hij niet goed' is geworden en bewusteloos is. De huisarts kent Henk als insuline afhankelijke diabetespatient, weet dat hij tot nu toe tweemaal in coma is geraakt, êen keer was het een hypo en ến keer een hyperglycaemisch coma. De huisarts gaat direct en treft patiènt subcomateus aan. De ademhaling is diep. Er staan een achttal lege bierflesjes naast de patiènt op de grond.

Voor de diagnose: ketoacidotisch-hyperglycaemisch coma pleiv/pleiten:

93. - Het klinisch beeld

94. - De alcoholconsumptie (acht flesjes bier)

De huisarts - nog onervaren - is niet zeker van zijn zaaik en weet niet goed hoe te handelen. Hij besluit 1 ampul van $20 \mathrm{cc} 20 \%$ glucose-oplossing intraveneus toe te dienen.

95. - In geval van twijfel tussen hypo- en hyperglycaemisch coma is dit een correcte handelwijze

\section{Casus 16}

Mevrouw Muller, 68 jaar, komt bij de huisarts op het spreekuur voor de driemaandelijkse. controle van haar diabetes type II. Ze is de laatste jaren redelijk gereguleerd. Laatste. bloedsuikers ( 3 maanden geleden) nuchter: 8,2, 2 uur pp 10,4 mmol/L. Urinereductie negatiel. Ze heeft een licht overgewicht. Ze gebruikt een calone beperkt dieet. Geen medicatie.

Patiênte vertelt dat ze zich de laatste dagen niet goed voelt. De assistente komt binnen en vertelt dat de urinerductie +++ bedraagt en de niet-nuchtere bloedsuiker 23,5 mmol/L. Een grondige anarnnese levert op dat patiěnte:

- afgelopen week een fikse griep doormaakte

- voor de koorts en de hoofdpijn Acetosal@gebruikte (4 dd 0,5 gram)

- laxeerthee gebruikt

- voor gewrichtspijn af te toe een tabletje fenylbutazon gebruikt.

- de laatste tijd veel druiven eet.

Tot de verhoging van de bloedsuiker heefthebben mogelijk geleid: 
96. - De griep

97. - De Acetosalø

98. - Laxeenthee

99. - Het fenylbutazon preparaat

100.- De druiven

Patiente klaagt over minder goed zien met het rechteroog. De huisarts vindt bij onderzoek een lichte lens-troebeling rechts, te duiden als een beginnend cataract.

101.- Deze bevinding heeft geen relatie met het bestaan van de diabetes

Aan het eind van het consult klaagt patiente haar nood over het strenge dieet. Ze houdt zo van een glaasje jenever. Mag ze dat echt niet hebben? De huisarts deelt haar mede dat ze zich, gezien haar diabetes, inderdaad geheel moet onthouden van alcohol.

\section{2.- Dit is correct}

\section{Casus 17}

Mevrouw Smit, 38 jaar oud, bekend met type I diabetes vraagt een visite aan wegens koorts en misselijkheid. Mevrouw spuit Rapitard (8) insuline 's morgens 36E en 's avonds 12E. De huisarts treft haar om 14.00 uur in bed aan. Ze ziet er ziek uit.

De temperatuur zojuist gerneten is $390 \mathrm{C}$. Ze heeft én keer gebraakt.

Na onderzoek stelt de huisarts de waarschijnlijkheidsdiagnose banale gastro-enteritis.

Patiente vertelt dat ze sinds gisteravond niets meer gegeten heft, ze vraagt of het daarom niet beter is de insuline-therapie te staken.

De huisarts adviseert haar om de avonddosis over te slaan en de dosis voor de volgende ochtend te verlagen tot $24 \mathrm{E}$.

\section{3.- Dit is een correct advies}

De huisarts geeft het volgende recept voor een vloeibare maaltijd. $250 \mathrm{ml}$ yoghun, $125 \mathrm{gr}$. banaan, 1 eerlepel slagroom, 1 eetlepel suiker en 1 glas sinaasappelsap.

104.- Deze vloeibare maaltijd is een adequate vervanging voor de hoofdmaaltijd van een zieke diabeet

De huisarts komt om 19.00 uur nog eens kijken. Er is niets veranderd. De huisarts vraagt zich af wanneer hij opname van patiente zou moeten overwegen. Tot de criteria voor opname in het geval van Mevrouw Smit op dit tijdstip behoor/behoren:

105.- Acetonurie

106. - glucosurie

107. - Temperatuur boven $39,50 \mathrm{C}$

108.- Aanhoudend braken, langer dan 12 uur 


\section{Aanvullende vragen}

109. - De compliance van patiênten met type II diabetes ten aanzien van controle en behandeling is volgens het daarnaar verrichte onderzoek groter dan $80 \%$

Er bestaat in Nederland een georganiseerde diabetes nazorg, onder andere gericht op hulp bij praktische problemen betreffende de suikerziekte (onder andere hulp bij spuiten en verzorging).

\section{0. - De zorg gaat uit van de districtgeneeskundige diensten}

Een diabetespatiènt mag de met zijn ziekte verband houdende ziektekosten opvoeren als aftrekpost voor de inkomstenbelasting.

111. - Hieronder vallen ook de kosten verbonden aan het dieet

112. - Bij verlenging van het rijbewijs moet elke diabetespatiênt door een arts gezien worden

113. - Een insuline afhankelijk diabeet kan geen bus- of vrachtwagenchauffeur worden

114. - Het eten van blokjes kaas bij een borrel voorkomt het optreden van alcohol geinduceerde hypoglycaemie

De volgende sporten zij̄n niet geschikt voor beoefening door type I diabeten:

115.- Voetbal

116.- Zwemmen

117.- Wielrennen

118. - Atletiek

119. - Boksen

120. - Een half uur sporten kost $\pm 50 \mathrm{k}$ cal koolhydraten extra

121. - Bij vliegreizen van zes, uur dient bij type II diabeten de tabletmedicatie angepast te worden

122. - Een diabetespatiẻnt die drie weken op vakantie naar Marokko gaat en insuline spuit kan dit alleen doen als hij de beschikking heeft over een koelkast voor zijn insulinevoorraad

123. - Ploegendiensten zijn niet mogelijk voor insuline afhankelijke diabetespatiénten

124. - Twintig jaar na het stellen van de diagnose diabetes heef́ $30 \%$ van de patiénten een diabetische retinopathie.

125. - De Hbalc waarde geeft een indruk van de gemiddelde bloedsuikerwaarde over de voorafgaande zes weken

126. - Diabeten hebben evenveel last van cariês dan niet diabeten. 
tagntr thoslluwat

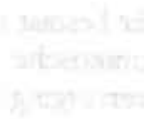

3 


\section{Sectie evaluatie interfacultair overleg huisartsgeneekunde}

Antwoordformulier landelijke toets diabetes in de huisartspraktijk toets - 1

Naam

formulier

(4 t.m. 8)

Huisartsinstituut

Universiteit van

$(9,10)$

\begin{tabular}{|c|c|c|c|c|c|c|c|c|}
\hline $\begin{array}{l}\text { pons } \\
\text { code }\end{array}$ & $\begin{array}{l}\text { vraag } \\
\mathrm{nr}\end{array}$ & $\begin{array}{l}\text { omcirkel je } \\
\text { antwoord }\end{array}$ & $\begin{array}{l}\text { pons } \\
\text { code }\end{array}$ & $\begin{array}{l}\text { vraag } \\
\mathrm{nr}\end{array}$ & $\begin{array}{l}\text { omcirkel je } \\
\text { antwoord }\end{array}$ & $\begin{array}{l}\text { pons } \\
\text { code }\end{array}$ & $\begin{array}{l}\text { vraag } \\
\mathrm{nr}\end{array}$ & $\begin{array}{l}\text { omcirkel je } \\
\text { antwoord }\end{array}$ \\
\hline 12 & 1 & juist ? onjuist & 54 & 43 & juist ? onjuist & 27 & 85 & juist ? onjuist \\
\hline 13 & 2 & juist ? onjuist & 55 & 44 & juist ? onjuist & 28 & 86 & juist ? onjuist \\
\hline 14 & 3 & juist ? onjuist & 56 & 45 & juist ? onjuist & 29 & 87 & juist ? onjuist \\
\hline 15 & 4 & juist ? onjuist & 57 & 46 & juist ? onjuist & 30 & 88 & juist ? onjuist \\
\hline 16 & 5 & juist ? onjuist & 58 & 47 & juist ? onjuist & 31 & 89 & juist $?$ onjuist \\
\hline 17 & 6 & juist ? onjuist & 59 & 48 & juist ? onjuist & 32. & 90 & juist ?' onjuist \\
\hline 18 & 7 & juist ? onjuist & 60 & 49 & juist ? onjuist & 33. & 91 & juist $?$ onjuist \\
\hline 19 & 8 & juist ? onjuist & 61 & 50 & juist ? onjuist & 34 & 92 & juist ? onjuist \\
\hline 20 & 9 & juist ? onjuist & 62 & 51 & juist ? onjuist & 35 & 93 & juist ? onjuist \\
\hline 21 & 10 & juist ? onjuist & 63 & 52 & juist ? onjuist & 36 & 94 & juist ? onjuist \\
\hline 22 & 11 & juist ? onjuist & 64 & 53 & juist ? onjuist & 37 & 95 & juist ? onjuist \\
\hline 23 & 12 & juist ? onjuist & 65 & 54 & juist ? onjuist & 38. & 96 & juist ?' onjuist \\
\hline 24 & 13 & juist ? onjuist & 66 & 55 & juist ? onjuist & 39 & 97 & juist $?$ onjuist \\
\hline 25 & 14 & juist ? onjuist & 67 & 56 & juist ? onjuist & 40 & 98 & juist ? onjuist \\
\hline 26 & 15 & juist ? onjuist & 68 & 57 & juist ? onjuist & 41 & 99 & juist ? onjuist \\
\hline 27 & 16 & juist ? onjuist & 69 & 58 & juist ? onjuist & 42 & 100 & juist ? onjuist \\
\hline 28 & 17 & juist ? onjuist & 70 & 59 & juist ? onjuist & 43 & 101 & juist ? onjuist \\
\hline 29 & 18 & juist ? onjuist & 71 & 60 & juist ? onjuist & 44 & 102 & juist ? onjuist \\
\hline 30 & 19 & juist ? onjuist & 72 & 61 & juist ? onjuist & 45 & 103 & juist ? onjuist \\
\hline 31 & 20 & juist ? onjuist & 73 & 62 & juist ? onjuist. & 46 & 104 & juist ? onjuist \\
\hline 32 & 21 & juist ? onjuist & 74 & 63 & juist ? onjuist & 47 & 105 & juist ? onjuist \\
\hline 33 & 22 & juist ? onjuist & 75 & 64 & juist ? onjuist. & 48 & 106 & juist ? onjuist \\
\hline 34 & 23 & juist ? onjuist & 76 & 65 & juist ? onjuist. & 49 & 107 & juist ? onjuist \\
\hline 35 & 24 & juist ? onjuist & 77 & 66 & juist ? onjuist. & 50 & 108 & juist ? onjuist \\
\hline 36 & 25 & juist ? onjuist & 78 & 67 & juist ? onjuist & 51 & 109 & juist $?$ onjuist \\
\hline 37 & 26 & juist ? onjuist & 79 & 68 & juist ? onjuist & 52 & 110 & juist ? onjuist \\
\hline 38 & 27 & juist ? onjuist & 80 & $69:$ & juist ? onjuistst & 53 & 111 & juist ? onjuist \\
\hline 39 & 28 & juist ? onjuist & 12 & 70 & juist ? onjuist & 54 & 112 & juist ? onjuist \\
\hline 40 & 29 & juist ? onjuist & 13 & 71 & juist ? onjuist & 55 & 113 & juist ? onjuist \\
\hline 41 & 30 & juist ? onjuist & 14 & 72 & juist ? onjuist & 56 & 114 & juist ? onjuist \\
\hline 42 & 31 & juist ? onjuist & 15 & 73 & juist ? onjuist & 57 & 115 & juist ? onjuist \\
\hline 43 & 32 & juist ? onjuist & 16 & 74. & juist ? onjuist & 58 & 116 & juist ? onjuist \\
\hline 44 & 33 & juist ? onjuist & 17 & 75 & juist ? onjuist & 59 & 117 & juist ? onjuist. \\
\hline 45 & 34 & juist ? onjuist & 18 & 76 & juist ? onjuist & 60 & 118 & juist ? onjuist \\
\hline 46 & 35 & juist ? onjuist & 19 & 77 & juist ? onjuist & 61 & 119 & juist ? onjuist \\
\hline 47 & 36 & juist ? onjuist & 20 & 78 & juist ? onjuist & 62 & 120 & juist ? onjuist \\
\hline 48 & 37 & juist ? onjuist & 21 & 79 & juist ? onjuist & 63 & 121 & juist ? onjuist \\
\hline 49 & 38 & juist? onjuist & 22 & 80 & juist ? onjuist & 64 & 122 & juist ? onjuist \\
\hline 50 & 39 & juist ? onjuist & 23 & 81 & juist ? onjuist & 65 & 123 & juist ? onjuist \\
\hline 51 & 40 & juist? onjuist & 24 & 82 & juist ? onjuist & 66 & 124 & juist ? onjuist. \\
\hline 52 & 41 & juist ? onjuist. & 25 & 83 & juist ? onjuist & 67 & 125 & juists ? onjuist. \\
\hline 53 & 42 & juist ? onjuist & 26 & 84 & juist ? onjuist & 68 & 126 & juist ? onjuist \\
\hline
\end{tabular}





\section{Casus 1}

1. juist

2. juist

3. juist

4. onjuist

Casus 2

5. juist

6. juist

7. onjuist

8. onjuist

9. vervallen

10. onjuist

11. juist

12. vervallen

13. juist

14. vervallen

15. juist

Casus 3

16. onjuist

17. onjuist

Casus 4

18. juist

19. juist

20. juist

21. juist

22. onjuist

23. onjuist

24. onjuist

25. onjuist

Casus 5

26. onjuist

27. vervallen

28. juist.

29. juist

30. onjuist

\section{Casus 6}

31. juist.

32. onjuist

33. juist

34. juist

35. juist

\section{Casus 7}

36. onjuist

37. juist

38. juist

39. onjuist

40. vervallen

41. verval'en

\section{Casus 8}

42. juist
43. juist

44. juist

45. vervallen

46. vervallen

47. onjuist

48. onjuist

49. juist

50. juist

51. juist

52. juist

53. juist

Casus 9

54. juist

55. onjuist

56. juist

57. juist

58. juist

59. juist

60. juist

61. onjuist

62. juist

63. juist

64. onjuist

65. juist

66. juist

Casus 10

67. juist

68. onjuist

69. juist.

70. juist

71. onjuist

Casus 11

72. juist.

73. onjuist

74. vervallen

Casus 12

75. juist

76. juist.

77. onjuist

78. juist

79. onjuist

C.asus 13

80. juist

81. juist

82. juist

83. onjuist

84. juist

85. juist

86. juist

87. onjuist
88. onjuist

Casus 14

89. onjuist

90. juist

91. onjuist

92. onjuist

Casus 15

93. juist

94. vervallen

95. vervallen

Casus 16

96. juist

97. onjuist

98. onjuist

99. onjuist

100. juist

101. onjuist

102. onjuist

Casus 17

103. onjuist.

104. juist

105. juist

106. onjuist

107. onjuist

108. juist

\section{Aanvullende vragen}

109. onjuist

110. onjuist

111. juis:

112. juist

113. juist

114. onjuist

115. onjuist

116. onjuist

117. onjuist

118. onjuist

119. juist

120. juist

121. onjuist

122. onjuist

123. vervallen

124. vervallen

125. juist

126. onjuist 


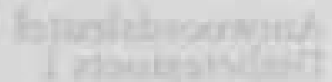
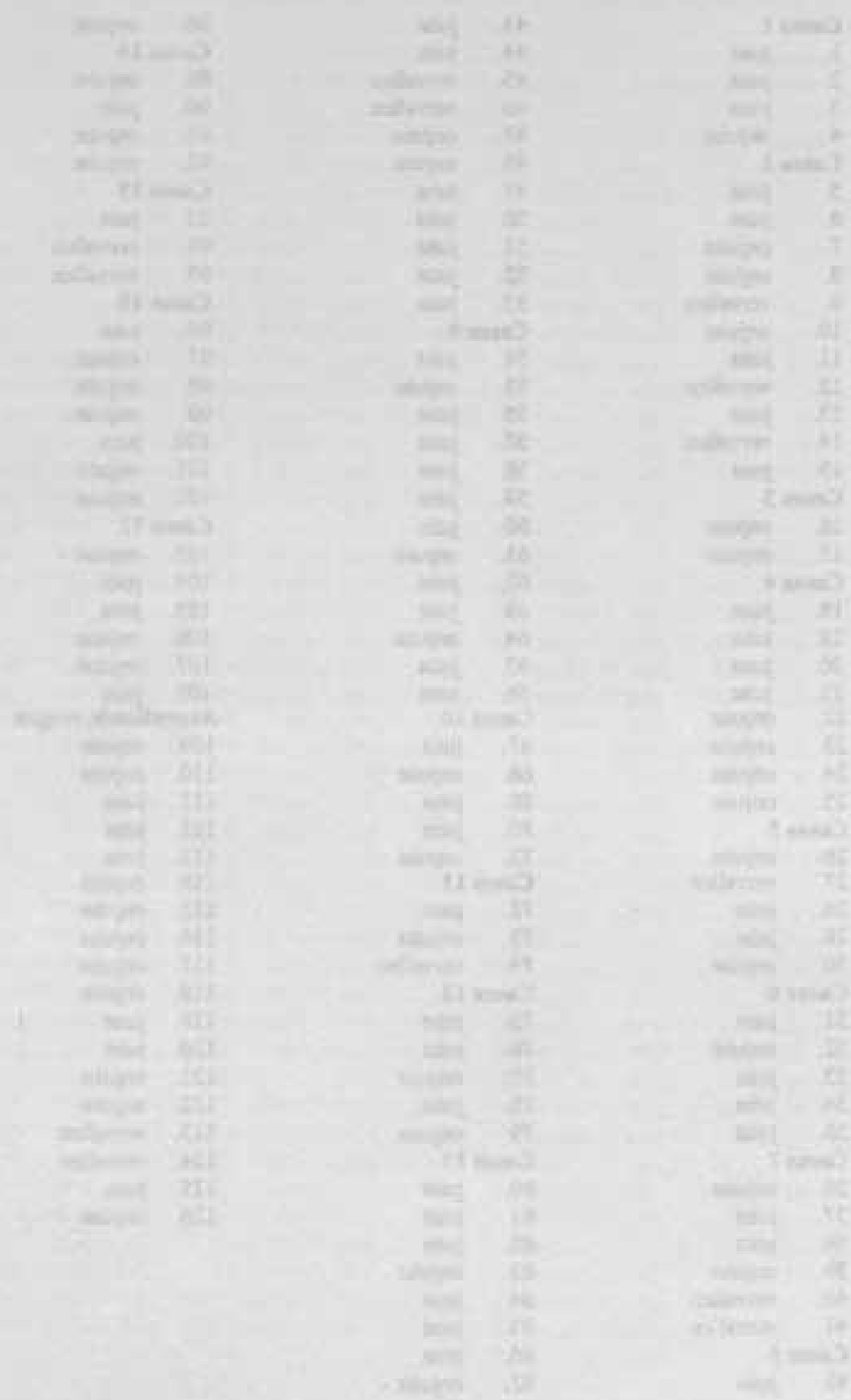


\section{Bijlage 2}

Landelijke toets diabetes in de huisartspraktijk

Voor artsen in opleiding tot huisarts

Toets 2

Sectie Evaluatie Interfacultair Overleg Huisartsgeneeskunde 


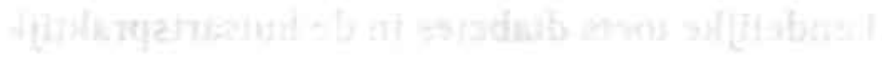

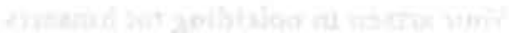




\section{Toelichting landelijke toets diabetes in de huisartspraktijk}

In deze toets worden zeventien patiènten voorgesteld die contact hebben met hun huisarts over klachten en problemen rondom diabetes. Over deze klachten en problemen en ook over de handelwijze van de huisarts worden vragen gesteld.

N.B.: de opgevoerde huisartsen gaan niet altijd volgens "het boekje" te werk.

De in de toets gehanteerde indeling van Diabetes Mellitus is:

- Type 1 = insuline afhankelijke Diabetes Mellitus: IDDM

- Type II = niet insuline afhankelijke Diabetes Mellitus: NIDDM

De toets bevat 124 vragen (er moeten dus 124 antwoorden worden gegeven).

In de tekst wordt elke vraag voorafgegaan door een nummer en twee streepjes -

De vragen staan in de vorm van een bewering. Tekst tussen haakjes is bedoeld als aanvullende informatie, deze is steeds correct en behoeft niet beoordeeld te worden.

Los van de toets worden acht aanvullende vragen over je opleiding en ervaring gesteld (bijlage).

Bij de beantwoording van de toetsvragen kun je kiezen tussen drie mogelijkheden JUIST / ? / ONJUIST.

Jouw antwoord op een vraag noteer je als volgt op het bijgevoegde antwoordformulier.

Negeer de kolom ponscode.

De cijfers in de kolom vraagnr. corresponderen met de nummers van de vragen.

Omcirkel daarvan het gekozen antwoord.

pons vraag omcirkel je antwoord code nr.

$\begin{array}{lllllll}\text { Een antwoord JUIST op vraag } 3 & 14 & 3 & \text { JUIST ? } & \text { ONJUIST } \\ \text { Een eventuele correctie } & & & \text { JUIST ? } & \text { ONJUIST } \\ \text { Een eventuele tweede correctie } & & & \text { JUIST ? } & \text { ONJUIST }\end{array}$

Het maken van de toets neemt ongeveer eén uur in beslag. Na afloop lever je het antwoordformulier in + de ingevulde bijlage. Beide moeten voorzien zijn van je naam en de naam van het huisartsinstituut waar je de beroepsopleiding tot huisarts volgt. Dit laatste is nodig in verband met de terugrapportage van de resultaten (zie Rapportage resultaten). Het rode boekje met de vragen kun je behouden.

\section{Raportage resultaten}

Elke deelnemer/deelneemster aan de Diabetes-toets krijgt ongeveer twee maanden na afname van de toets een overzicht van de eigen resultaten en van de gemiddelde landelijke resultaten en. de gehanteerde antwoordsleutel.

De resultaten worden weergegeven in het percentage GOED / ? / FOUT-antwoorden per casus, per rubriek (Diagnostiek IDDM/Beleid/Voorlichting e.d.) en over de toets in zijn geheel.

Een beoordeling van de resultaten in de zin van voldoende/onvoldoende wordt niet gegeven omdat een norm hiervoor niet is vastgesteld. Deelname aan de toets heeft dus geen consequenties voor de beoordeling van jouw resultaten in de beroepsopleiding tot huisarts. 


\section{Casus 1}

De heer Driessen, een 78-jarige, redelijk vitale, alleenstaande man vraagt een visite aan voor pijn aan zijn voet. 's Middags komt de huisarts bij hem langs.

Patient is sinds 10 jaar bekend met een milde type II diabetes mellitus (bloedsuiker nooit boven de $14 \mathrm{mmol} / \mathrm{L}$ ), waarvoor hij dieet houdt.

Bij onderzoek blijkt patiènt een kleine ulcus ter plaatse van het kopje van metatarsale I van de rechtervoet te hebben. Er zit een rode rand om het ulcus.

De heer Driessen vertelt dat hij twee weken geleden een wandeling heeft gemaakt, waama hij last kreeg van pijn aan zijn voet.

De huisarts concludeert: diabetisch ulcus na overbelasting.

1. - Dit is inderdaad de meest waarschijnlijke diagnose

Hij adviseert patiént om driemaal daags zijn rechtervoet in een sodabad te zetten.

2. - Dit is een correct advies in dit geval

Tot de instructie voor voetverzorging bij de heer Driessen behoort/behoren:

3. - Het dragen van sokken van een vochtabsorberend materiaal (bijvoorbeeld: wol of badstof?

4. - Het niet dragen van kapotte of gestopte sokken

5. - Het dagelijks controleren van de binnenkant van de schoenen op oneffenheden

6. - Het dagelijks wisselen van schoenen

7. - Het regelmatig inspecteren van de voeten

\section{Casus 2}

Mevrouw de Wit, 50 jaar, komt bij haar huisarts voor controle van haar type II diabetes (NIDDM). Sinds acht jaat is zij bekend met diabetes. Zij is ingesteld met een dieet. Dit keer staat het jaarlijks onderzock naar mogelijke complicaties van de diabetes op het programma. De huisars begint het onderzoek met het nalopen van mogelijke uitingen van diabetische neuropathie.

8. - Het testen van de sensibiliteit van de ledematen proximaal is in dit kader zinvoller dan distaal

9. - Het onderzoek van de nervus VI (abducens) is in dit kader zinvoller dan het onderzoek van de nervus VIIl (vestibulo-chochlearis)

10. - Het letten op zowel atrofie van de voetspieren als op trofische stoornissen van de voeten is in dit kader zinvol

11. - Het testen van de APR is in dit kader zinvoller dan het testen van de voetzoolreflex

12. - Bij cen diabetische neuropathie van de voet blijft de vibratiezin doorgaans langer intact dan de pijnzin 
Vervolgens wordt gekeken naar met diabetes samenhangende complicaties op oogheelkundig gebied.

13. - In geval van beginnend cataract is de indirecte fundusscoop beter geschikt om het retinale vaatbed te bekijken dan de directe fundusscoop

14. - Het testen van de visus op 6 meter afstand is niet zinvol omdat het centrale zien bij diabetes niet aangetast raakt

15. - Voor het vaststellen van ernst en localisatie van diabetische retinopathie is het met de hand testen van de gezichtsvelden aangewezen.

De huisarts meet de oogboldruk.

16. - Dit is zinvol omdat diabetespatienten een verhoogd risico hebben op glaucomasimplex

Dan wordt gekeken naar complicaties van diabetes op het vaatstelsel.

17. - Bij goed pulserende voetarterién levert onderzoek van de arteria femoralis (palpatie + auscultatie) geen aanvullende informatie op

18. - De aanwezigheid van varices (met name in het vena saphena parva gebied) is kenmerkend voor diabetische vaatcomplicaties

\section{Casus 3}

De heer Van de Broek, 73 jaar, komt op het spreekuur voor tensiecontrole. Hij is pas kort in de praktijk. Na het overlijden van zijn vrouw, een half jaar geleden is hij verhuisd om dichter bij zijn dochter in de buurt te wonen. Zijn hypertensie wordt behandeld met 1 maal daags 1 tablet Moduretic@(5 mg amiloride + 50 mg hydrochloor thiazide).

Tensie nu: 160/90 mm Hg.

De huisarts ziet in de aantekeningen van de vorige huisarts dat er een tijdlang suiker in de urine is gevonden. Hiervoor kreeg patiént een jaar lang tolbutamide (Rastinon®) voorgeschreven. Het creatininegehalte was $65 \mathrm{micromol} / \mathrm{l}$.

Bij de laatste controle 3 maanden geleden was de reductie negatief en werd de tolbutamide gestopt. Patiēnt vertelt, dat hij zich de laatste tijd goed voel, redelijk gewend is aan zijnn nieuwe situatie en flink is afgevallen sinds hij weduwnaar is.

Bij urine-onderzoek is de reductie negatief.

19. - Dit betekent dat patiênt op dit moment bloedsuikerwaarden heeft die onder de $11 \mathrm{mmol} / \mathrm{L}$ blijven

Tot de mogelijke oorzaken van het verdwijnen van de eerder geconstateerde glucosurie behoor/behoren:

20. - Het gebruik van Moduretic@

21. - Het gewichtsverlies 


\section{Casus 4}

Mevrouw Werkman, 28 jaar, stapt de spreekkamer binnen. Ze is drie weken over tijd en kreeg net van de assistente te horen dat de zwangerschapsreactie positief was. Dit is de eerste keer, dat ze zwanger is. Ze heeft een aantal vragen opgeschreven, die ze met haar huisarts, wil bespreken. Haar moeder heeft suikerziekte. De huisarts weet dat dit een insuline afhankelijke diabetes is. Patiente vraagt of ze daardoor een verhoogde kans op zwangerschapssuiker heeft.

22. - Mevrouw Werkman heeft inderdaad een grotere kans op zwangerschapsdiabetes dan iemand zonder deze familie-anamnese

Patiente vraagt nu of zwangerschapssuiker meer kans geeft op afwijkingen bij het kind. De huisarts vertelt dat er inderdaad een verhoogd risico op aangeboren afwijkingen is bij zwangerschapsdiabetes.

\section{3. - Dit is correct}

Vervolgens deelt patiente mee, dat ze graag thuis zou willen bevallen, ook in geval van. zwangerschapssuiker. De huisarts raad haar dit af.

Argumenten tegen een thuisbevalling in zo'n geval zijn onder andere:

24. - Een verhoogde kans op fluxus post partum

25. - Kans op hypoglycaemie post partum bij het kind

Vier maander: later komt patiénte voor controle. Ze klaagt over een branderig gevoel bij het plassen en vaginale afscheiding. De assistente meldt dat suiker in de urine zit. Mevrouw Werkman zegt: "Zie je wel, toch suikerziekte."

De huisarts antwoordt: "Dat hoeft niet per se." De huisarts heeft gelijk.

26. - De reden hiervoor is dat de nierdrempel voor glucose in de zwangerschap verlaagd is

27. - Voor het stellen van de diagnose zwangerschapsdiabetes is een orale glucosetolerantietest aangewezen.

In de zesde maand wordt bij obstetrische controle een positieve dyscongrueritie gevonden.

28. - Een van de mogelijke oorzaken hiervan is zwangerschapsdiabetes

\section{Casus 5}

De heer Bakker, 56 jaar oud, komt op het diabetesspreekuur van zijn huisarts voor controle van zijn sinds een half jaar bestaande type II diabetes mellitus. Zijn gewicht is nu 78 kilo bij een lengte van $172 \mathrm{~cm}$.

Met hulp van de dietiste is hij vier kilo afgevallen in de loop van zes maanden. De bloedsuiker is nu $15 \mathrm{mmol} / \mathrm{L}$ (vootheen $17.14 \mathrm{en} 16 \mathrm{mmol}$.).

De huisarts besluit om patiènt 1 tablet gliclazide (Diamicron(8)) 's ochtends, voor te schijiven.

29. - In het geval van de heer Bakker is het beter om een sulfonylureum preparaat uit de 
eerste generatie (zoals tolbutamide) voor te schrijven dan een tweede generatiepreparaat zoals Diamicron@

Tot de verschillen tussen eerste en tweede generatie preparaten behoortbehoren:

30. - Eerste generatie-preparaten werken minder sterk bloedsuikerverlagend dan die van de tweede generatie

31. - Eerste generatie preparaten hebben een kortere werkingsduur

32. - Tweede generatie-preparaten geven meer kans op levensbedreigende hypoglycaemieên

\section{Casus 6}

Mevrouw Wagemakers, 65 jaar oud, komt bij haar huisarts met de mededeling dat de longarts een "beetje suiker" bij haar geconstateerd heeft. Ze is al jaren bij de longarts voor CARA. Ze gebruikt $5 \mathrm{mg}$ prednison per dag, $250 \mathrm{mg}$ theofylline (Theolair retard@) en 3 dd $4 \mathrm{mg}$ salbutamol (Ventolin(1).

Lengte $1.72 \mathrm{~m}$, gewicht 80 kilo.

De longarts heeft haar naar een diétist gestuurd. Ze kreeg een vetbeperkt dieet voorgeschreven. Ze snapt er niets van. De huisarts legt haar uit dat een vetbeperking effectiever is om af te vallen dan een suikerbeperking.

33. - De reden hiervan is dat de energetische voedingswaarde van vetten vier keer zo hoog is als die van koolhydraten

De huisarts legt uit dat de suikerziekte met de medicatie kan samenhangen.

Tot de mogelijke oorzaken van een verminderde glucosetolerantie in dit geval behoortbehoren:

34. - Het prednisongebruik

35. - Het theofylline gebruik

36. - Het salbutamolgebruik

Patiénte vraagt nog wat door over het dieet. De huisarts vertelt dat er tegenwoordig bij dit soort gevallen geen absoluut suikerverbod meer wordt gegeven. Hij zegt: "als $\mathrm{U}$ rekening houdt met het totaal aantal calorieēn dat $U$ op een dag mag gebruiken, mag $U$ best af en toe een gevulde koek eten."

37. - Dit advies is conform de huidige inzichten met betrekking tot behandeling van diabetes

Mevrouw Wagemakers laat de dokter een potje sorbitol-tabletten zien, dat ze alvast heeft aangeschaft. De huisarts raadt haar het gebruik hiervan (als suikervervangend middel) af.

38. - De reden hiervoor is, dat sorbitol-tabletten teveel kalium bevatten

Mevrouw Wagemakers wil nog weten of het gebruik van rauwkost en bruin brood goed voor haar is, nu ze suiker heeft. De huisarts vertelt haar dat dit met name voor diabetespatiênten goede voeding is. 


\section{Casus 7}

Mevrouw Tahimala, 51 jaar oud, is dertig jaar geleden uit Indonesiê naar Nederland verhuisd. $\mathrm{Zij}$ is sinds acht jaar geleden bekend met een niet insuline afhankelijke diabetes. Zij is pas een jaar in de praktijk, na een verhuizing. Ze gebruikt 's ochtends 2 en 's avonds 1 tablet tolbutamide (Rastinon@) van $500 \mathrm{mg}$.

Zij komt nu met klachten over pijn in de schouder. De huisarts besluit van de gelegenheid gebruik te maken om de bloedsuiker te bepalen. Hij gebruikt hiervoor een teststrip, waarop hij een druppel bloed, die hij uit haar vinger heeft geprikt, laat vallen. De strip wordt met behulp van een meetapparaat (bijv. Reflocheck@) electronisch afgelezen. Resultaat: $17 \mathrm{mmol} / \mathrm{L}$.

40. - Bij gebruik van deze methode kan de huisarts ervan op aan, dat de werkelijke waarde van de bloedsuiker (uitgaand van een bepaling in een klinisch chemisch lab) zeker tussen de 15 en $19 \mathrm{mmol} / \mathrm{l}$ ligt

Uit het gesprek hierover wordt duidelijk dat patiênte nog niet eerder is geprikt en eigenlijk niets weet over haar aandoening. Ze was gewend om elke drie maanden een herhaalrecept bij de assistente te halen.

41. - Om te komen tot een goede "compliance" ten aanzien van therapie en controle is in dit geval het opleggen van een strak driemaandelijks controleschema de meest aangewezen methode

Mevrouw is $1.49 \mathrm{~m}$ lang en weegt 46 kilo.

42. - Een verwijzing naar de diêtiste is in dit geval niet nodig

Patiènte woont alleen. Haar twee dochters komen elk apart $1 \mathrm{x}$ per week 's avonds bij haar eten. Zij kookt dan uitgebreid "Indonesisch". De resterende maaltijden zijn "Hollands" van samenstelling.

43. - In dit geval is de meest aangewezen weg voor cen betere diabetesregulatie dat Mevrouw helemaal "Hollands" gaat. eten

Bij lichamelijk onderzoek blijkt de vibratiezin aan de voeten gestoord te zijn. Bovendien is er beiderzijds sprake van een hallux valgus met eeltvorming.

44. - In dit geval zijn de kosten van een pedicure als aftrekpost bij de inkomstenbelasting op te voeren

Bij deze patiente zal het ziekenfonds de volgende materialen voor zelfcontrole vergoeden:

45. - Urineteststrips voor glucose

46. - Bloedsuikerteststrips 


\section{Casus 8}

De heer Janssen, 50 jaar, komt op het spreekuur met klachten over nachtelijke krampen en branderig gevoel in de benen, links meer dan rechts. Daarnaast heeft hij wel eens nekpijn en ziet hij soms wat wazig. Tenslotte vertelt hij dat hij moeite heeft om een erectie te krijgen.

Bij lichamelijk onderzoek constateert de huisarts:

- RR 140/70

- doorgezakte voetgewelven

- hypertone nekmusculatuur

- visus li=re $=1.0$

- lengte $1.82 \mathrm{~m}$, gewicht 92 kilo

De huisarts overweegt de diagnose diabetes mellitus, al dan niet met complicaties. Bij deze diagnose past/passen:

\section{7. - De nachtelijke krampen in de benen}

48. - Het branderig gevoel in de benen

49. - De nekpijn

50. - Het wazig zien

51. - De erectiestoomis

De huisarts besluit een bloedsuiker 2 uur na de maaltijd te laten bepalen om diabetes aan te tonen of uit te sluiten.

52. - Het aanvragen van een OGTT (orale glucose tolerantie) zou in dit geval juister zijn geweest dan het bepalen van een bloedsuiker 2 uur postprandiaal

De huisarts laat in het verloop van drie maanden driemaal een bloedsuiker twee uur na de maaltijd bepalen (waarden: 17, 15 en $13 \mathrm{mmol} / \mathrm{L}$ ). Hij heeft de heer Janssen 3 dd $5 \mathrm{mg}$ glibenclamide voorgeschreven (Daonil@). Nu, na drie maanden therapic, is de bloedsuiker nog $12 \mathrm{mmol}$.

53. - Op dit moment is de meest aangewezen handelwijze om patient te verwijzı"n naar een diëtiste voor gewichtsreductie

De huisarts besluit de dosering van glibenclamide op te hogen naar $10 \mathrm{mg}$ 's ochtends en naar $7,5 \mathrm{mg}$ 's middags en 's avonds. Twee weken later meldt de heer Janssen zich weer. Hij voelt zich niet lekker. Hij klaagt over slecht slapen, hoofdpijn en duizeligheid.

54. - Al deze klachten zijn toe te schrijven aan het medicatiegebruik

\section{Casus 9}

De heer Konings, een 32-jarige magazijnbediende bij een groothandel in levensmiddelen, sinds een jaar beke:ıd met insuline afhankelijke diabetes is op zijn werk onwel geworden. De huisarts wordt gebeld en gaat direct poolshoogte nemen. Zij treft hem aan op een stoel in het kantoorije van zijn baas. Hij is bleek en het zweet staat hem op het voorhoofd, hij lijkt wat opgewonden. 
De huisarts denkt aan een hyperglycaemie.

Bij verdenking op een hyperglycaemie is het aangewezen de volgende zaken na te vragen:

55. - Moeheid

56. - Dorst

57. - Droge mond

58. - Veel plassen

59. - Recente gewichtstoename

60. - Hoofdpijn

61. - Hartkloppingen

62. - Pijn op de borst

Tot de oorzaken van een hyperglycaemie bij een insuline afhankelijke diabetespatiênt behoortBehoren:

63. - Het te weinig insuline spuiten

64. - Het verrichten van meer lichamelijke inspanning dan normaal

65. - Een verkeerde verdeling van de hoeveelheid koolhydraten over de dag

66. - Het onder stress staan

Patiênt blijkt gêen klachten te hebben die passen bij een hyperglycaemie. De huisarts adviseert de heer Konings om een suikerklontje te nemen en een beschuit met kaas.

67. - Dit is een correct advies bij een hypoglycaemie

\section{Casus 10}

Om 23.00 uur wordt de huisarts van de heer Steensma, 58 jaaĩ oud, gebeld met de vraag am meteen te komer. Bij aankomst treft zij patiênt bleek en bezweet aan. Hij heeft geen pijn en vertelt ineens niet goed te zijn geworden. Tensie is $110 / 70$, pols 108 aequaal. Patient is al jaren bekend met type il diabetes waarvoor hij een dieet volgt en 2 dd 0,5 gram tolbutamide (Rastinon(8) inneemt. Hij heeft vandaag normaal gegeten. De heer Steensma is vanmiddag bij de uroloog geweest wegens een chronische prostatitis. Hij kreegt Bactrimel@ voorgeschreven (cotrimoxazol).

68. - De kans op een myocardinfarct is voor !emand als de heer Steensma ongeveer vijf keer zo hoog als voor een niet diabeet

De huisarts twijfelt tussen de diagnose myocardinfarct en hypoglycaemie.

69. - Het ontbreken van pijn op de borst bij een diabetespatiènt met een myocardinfarct kan verklaard worden door diabetische neuropathie 
Bij de diagnose hypoglycaemie past/passen:
70. - Het klinische beeld
71. - De combinatie tolbutamide-cotrimoxazol
72. - Het tijdstip (23.00 uur)

\section{Casus 11}

De heer Pijnenborg, 48 jaar, komt bij zijn huisarts met het verzoek om zijn bloedsuiker te laten bepalen. Bij zijn broer is namelijk recent suikerziekte geconstateerd. De huisarts besluit een orale glucosetolerantietest aan te vragen.

Uitslag:

- nuchter : $5 \mathrm{mmol}$

- na 1 uur : 9 mmol

- na 2 uur : $10 \quad \mathrm{mmol}$

Drie dagen later vertelt de huisarts de heer Pijnenborg dat hij geen echte suikerziekte heeft, maar wel aanleg daartoe. Op zijn kaart schrijft hij: verminderde glucosetolerantie.

Van verminderde glucosetolerantie (impaired glucose tolerance volgens de WHO-criteria) wordt gesproken indien de nuchiere glucose lager is dan $7 \mathrm{mmol} / \mathrm{L}$.

73. - En bovendien de twee uurs waarde van de bloedsuiker na belasting (met 75 gram glucose-oplossing) tussen de 8 en $11 \mathrm{mmol} /$ ligt (in capillair bloed)

De heer Pijnenborg heeft op grond van de uitslagen van de OGTT:

74. - Hetzelfde risico op hart- en vaatziekten als iemand met normale bloedsuikerwaarden

75. - Een kans van ongeveer $20 \%$ op het krijgen van bij diabetes passende bloedsuikerwaarden binnen 10 jaar

\section{Casus 12}

De heer Colenbrander is een 31-jarige man die bij de huisarts bekend is met een fors overgewicht. Hij weegt al jaren $104 \mathrm{kilo}$ bij een lengte van $1.80 \mathrm{~m}$. Hij komt nu op het. spreekuur vanwege een steenpuist in zijn nek. Patiënt heeft verder geen klachten, met name geen dorst en polyurie.

Bij onderzoek ziet de huisarts een fikse: furunkel in de: nekregio. Hij besluit de urine op suiker na te kijken. Er blijkt een forse glucosurie: te zijn; aceton negatiel. Een direct bepaalde bloedsuiker is $18 \mathrm{mmol} / \mathrm{L}$. De huisarts twiffelt tussen de diagnose: type 1 en type Il diabetes mellitus.

Voor de diagnose type I diabetes me!litus pleit/pleiten:
76. - De leeftijd
77. - De steenpuist 
Voor de diagnose type II diabetes mellitus pleit/pleiten:

78. - Het overgewicht

79. - De afwezigheid van aceton in de urine

80. - Het is waarschijnlijker dat deze patiênt een type II diabetes heeft dan een type I diabetes

\section{Casus 13}

De heer Lubbers, een 66-jarige vitale ex-stewart, komt bij zijn huisarts voor controle van zijn reeds twintig jaar bekende type II diabetes. Hij houdt hiervoor alleen een calorie beperkt dieet. De glucosewaarden 2 uur post prandiaal waren in het verleden steeds tussen de 9 en de 12 mmol. Tensie steeds rond de 150/85 mm Hg.

Patient is het afgelopen jaar niet op controle geweest wegens verblijf bij zijn dochter in Canada. De heer Lubbers presenteert nu spontaan een aantal klachten. Hij heeft last van: moeheid, duizeligheid 's ochtends bij het opstaan, dunne ontlasting 's avonds en 's nachts en moeilijk op gang komende mictie met nadruppelen.

Bovendien hoon hij duidelijk minder met het linkeroor.

Bij diabetes pasU/passen onder andere:

81. - De moeheid

82. - De duizeligheid 's ochtends bij het opstaan

83. - De slechthorendheid

Bij onderzoek blijkt patiènt zes kilo zwaarder te zijn, dan een jaar tevoren. De tensie is $170 / 100$ $\mathrm{mm} \mathrm{Hg}$. De assistente meldt een positieve reductie en eiwit in de urine. Bloedsuiker is $18 \mathrm{mmol}$, sediment geen afwijkingen.

Bovenstaandc bevindingen passen bij de diagnose: diabetische nefropathie.

84. - Tegen de diagnose diabetische nefropathie pleit de tot voor kon uitstekende diabetesregulatie

85. - De door de heer Lubbers naar voren gebrachte klacht over dunne ontlasting 's ayonds en 's nachts past bij een diabetische autonome neuropathie

De kans op een diabetische retinopathie bij de heer Lubbers is groot. Dit is af te leiden uit:

86. - De duur van de diabetes

87. - De leeftijd van de heer Lubbers

88. - De aanwezigheid van de combinatie hypertensie en proteinurie 


\section{Casus 14}

Mevrouw Lammers, 64 jaar, komt bij haar huisarts op het spreekuur met de klacht branderig gevoel bij bat plassen. Ze heeft het afgelopen half jaar driemaal een urineweginfectie doorgemaakt. Dit keer blijkt het sediment meer dan 10 leucos per gezichtsveld te bevatten. De huisarts besluit de urine nu tevens op de aanwezigheid van glucose te onderzoeken.

89. - Een reden hiervoor is dat vrouwelijke diabetespatiēnten vaker een urineweginfectie hebben dan vrouwen zonder diabetes

De reductie is negatief. Een die middag bepaalde bloedsuiker (2 uur na de maaltijd) blijkt 9.6 $\mathrm{mmol} / \mathrm{L}$ te zijn. De huisarts concludeert hieruit dat patiênte lijdt aan diabetes mellitus (type II).

\section{0. - Dit is correct}

Huisarts en patiente hebben een uitvoerig gesprek over de geconstateerde afwijkingen. Patiente vertelt vroeger tijdens de zwangerschap suikerziekte gehad te hebben. De huisarts vertelt dat ongeveer een kwart van de vrouwen met zwangerschapssuiker in hun latere leven suikerziekte krijgen.

\section{1. - Dit is correct}

\section{Casus 15}

De huisarts van Henk Ritselaar, een 24-jarige student psychologie, wordt 's avonds laat gebeld door een vriendin van patiẻnt met het bericht dat zij hem bewusteloos heeft aangetroffen. De huisarts kent Henk als een insuline afhankelijke diabetespatiênt en weet dat hij tot nu toe twee maal in coma is geraakt, éen keer door een hypo en eén keer door een hyperglycaemie.

De huisarts gaat direct en treft patient subcomateus aan. De ademhaling is diep. Er staan een achttal lege bierflesjes naast patiênt op de grond.

Voor de diagnose ketoacidotisch-hyperglycaemisch coma pleit/pleiten:

92. - Het afwijkende ademhalingspatroon

93. - De alcoholconsumptie

De huisarts besluit 20E insuline Actrapid Novo (kortwerkend insulinepreparaat) in te spuiter en een half uur af te wachten.

94. - Dit is een correcte handelwijze

\section{Casus 16}

Mevrouw Muller, 68 jaar, komt bij de huisarts op het spreekuur voor de drie maandelijkse controle van haar diabetes type II. $\mathrm{Ze}$ is de laatste jaren redelijk gereguleerd. Laatste bloedsuiker ( 3 maanden geleden) nuchter: $8,2 \mathrm{mmol}, 2$ uur pp: $12 \mathrm{mmol}$. Geen glucosurie. Ze heeft een licht overgewicht. Ze gebruikt een caloriebeperkt dieet. Geen medicatie. Patiente venelt dat ze zich de lastste dagen niet goed voelt.

De assistente belt de urine- en bloeduitslagen door: reductie ( +++$)$, niet nuchtere bloedsuiker $23,5 \mathrm{mmol} / \mathrm{L}$. 
Een grondige anamnese levert op dat patiênte:

- afgelopen week een fikse griep doormaakte

- hiervoor 4 dd 1 tablet paracetamol van 500 mg innam

- allang $\mathrm{KH} 3$ capsules (procaine $50 \mathrm{mg}$, hematoporfyrine 0,2 mg en enkele zouten) gebruikt "tegen de ouderdom"

- veel jus d'orange heeft gedronken

- voor gewrichtspijn regelmatig een paar tabletjes fenylbutazon gebruikt

- de laatste week veel bananen eet.

Tot de verhoging van de bloedsuiker heeft/hebben mogelijk geleid:

95. - De griep

96. - Het paracetamol gebruik

97. - Het jus d'orange gebruik

98. - Het fenylbutazon gebruik

99. - De bananen

100. - De KH3 capsules

Patiente klaagt over minder goed zien met het rechteroog. De huisarts vindt bij onderzoek een lichte lenstroebeling rechts, te duiden als een beginnend cataract.

101. - Cataract komt vaker voor bij diabeten dan bij niet-diabeten

Aan het eind van het consult klaagt patiènte haar nood over het dieet. Mag ze echt geen glaasje jenever? De huisarts zegt haar, dat ze met het oog op haar suikeiziekte beter droge witte wijn dan jenever kan drinken.

102.- Dit is correct

\section{Casus 17}

Mevrouw Smit, 38 jaar oud, bekend met type I diabetes, vraagt een visite aar wegens koons en misselijkheid. Mevrouw spuit Rapitard (1) insuline 's morgens $36 \mathrm{E}$ en 's avonds $12 \mathrm{E}$. De huisarts treft haar om 14.00 in bed aan. Haar temperatuur is $39 \circ \mathrm{C}$.

$\mathrm{Na}$ onderzoek houdt de huisarts het op een banale gastro-enteritis. Patiênte vertelt, dat ze niets meer gegeten heeft sinds vanochtend. Ze vraagt wat ze nu moet doen met de insuline injecties. De huisarts adviseert haar om de insulinedosering op te hogen (naar $4 \mathrm{OE}$ en 16E) zolang ze meer dan $380 \mathrm{C}$ koorts heeft.

103. - Dit is een correct advies

De huisarts geeft het volgende dieetadvies:

3 dd 1 zakje ORS oplossen in $300 \mathrm{ml}$ water (oral rehydration salt, bevat 6 gram glucose + $\mathrm{NaCl}$ en andere zouten) en 6 beschuiten met beleg naar keuze. 
De huisarts komt om 19.00 uur nog eens kijken. Er is geen verbetering. De huisarts vraagt zich af, wanneer hij opname van patiénte zou moeten overwegen.

Tot de criteria voor opname in het geval van Mevrouw Smit behoor/behoren:

105. - Aanhoudende temperatuur boven $380 \mathrm{C}$ (langer dan 3 dagen)

106. - Het optreden van diarree

107.- Het optreden van braken (langer dan 1 dag)

\section{Aanvullende vragen}

108. - De compliance van patiènten met type II diabetes ten aanzien van controle en behandeling is volgens daarnaar verricht onderzoek lager dan $75 \%$

Er bestaat in Nederland een georganiseerde diabetesnazorg, onder andere gericht op hulp bij spuiten en verzorging.

109. - Deze zorg gaat uit van de kruisverenigingen

110. - Bij verlenging van het rijbewijs moet elke diabetespatiènt door een specialist gezien worden

111. - Een insuline afhankelijke diabeet kan geen treinconducteur worden

Een diabetespatiènt mag de met zijn ziekte verband houdende kosten opvoeren als aftrekpost voor de inkomstenbelasting.

112. - Hieronder vallen ook de kosten voor naalden en spuiten

113. - Het eten van pinda's bij een borrel voorkomt het optreden van door alcohol geinduceerde hypoglycaemie.

114. - Een half uur sporten kost $\pm 200 \mathrm{kcal}$ koolhydraten extra

115. - Er zijn in Nederland ongeveer evenveel type I (IDDM) als type II (NIDDM) diabetespatiënten

De verpleegkundige van de diabetes thuiszorg rekent het tot zijn/haar taak om patiênten voor te lichten over hun aandoening.

116. - Deze voorlichting bestrijkt zowel medische als sociale problematiek

117. - De houdbaarheid van een niet aangebroken flacon insuline bij kamertemperatuiur is ongeveer zes weken

De Diabetesvereniging Nederland (DVN) te Utrecht is een patiéntenvereniging voor diabetespatienten. Tot de activiteiten van DVN behoort/behoren onder andere: 
118. - Voorlichting aan patiênten over dieet en medicatie

119. - Het organiseren van vakantiereizen

120.- Het vertegenwoordigen van de belangen van diabetespatienten bij de ziektekostenverzekeraars

De Hbalc waarde geeft een indruk van de gemiddelde bloedsuikerwaarde over de voorafgaande periode.

121. - Dit betreft een periode van éen week

De volgende hoestdranken zijn geschikt om voor te schrijven aan diabetespatiénten

122. - Promethazinesiroop

123.- Mixtura resolvens

124.- Bredon siroop 
Sectie evaluatie interfacultair overleg huisartsgeneeskunde

Antwoordformulier landelijke toets diabetes in de huisartspraktijk toets - 2

Naam

Huisartsinstituut formulier

Universiteit van
(4 t.m. 8$)$

$(9,10)$

\begin{tabular}{|c|c|c|c|c|c|c|c|c|}
\hline $\begin{array}{l}\text { pons } \\
\text { kode }\end{array}$ & $\begin{array}{l}\text { vraag } \\
\mathrm{nr}\end{array}$ & $\begin{array}{l}\text { omcirkel je } \\
\text { antwoord }\end{array}$ & $\begin{array}{l}\text { pons } \\
\text { kode }\end{array}$ & $\begin{array}{l}\text { vraag } \\
\mathrm{nr}\end{array}$ & $\begin{array}{l}\text { omcirkel je } \\
\text { antwoord }\end{array}$ & $\begin{array}{l}\text { pons } \\
\text { code }\end{array}$ & $\begin{array}{l}\text { vraag } \\
\mathrm{nr}\end{array}$ & $\begin{array}{l}\text { omcirkel je } \\
\text { antwoord }\end{array}$ \\
\hline 12 & 1 & juist ? onjuist & 54 & 43 & juist ? onjuist & 27 & 85 & juist ? onjuist \\
\hline 13 & 2 & juist ? onjuist & 55 & 44 & juist ? onjuist & 28 & 86 & juist ? onjuist \\
\hline 14 & 3 & juist ? onjuist & 56 & 45 & juist ? onjuist & 29 & 87 & juist ? onjuist \\
\hline 15 & 4 & juist ? onjuist & 57 & 46 & juist ? onjuist & 30 & 88 & juist ? onjuist \\
\hline 16 & 5 & juist ? onjuist & 58 & 47 & juist ? onjuist & 31 & 89 & juist ? onjuist \\
\hline 17 & 6 & juist ? onjuist & 59 & 48 & juist ? onjuist & 32 & 90 & juist ? onjuist \\
\hline 18 & 7 & juist ? onjuist & 60 & 49 & juist ? onjuist & 33 & 91 & juist ? onjuist \\
\hline 19 & 8 & juist ? onjuist & 61 & 50 & juist ? onjuist & 34 & 92 & juist ? onjuist \\
\hline 20 & 9 & juist ? onjuist & 62 & 51 & juist ? onjuist & 35 & 93 & juist ? onjuist \\
\hline 21 & 10 & juist ? onjuist & 63 & 52 & juist ? onjuist & 36 & 94 & juist ? onjuist \\
\hline 22 & 11 & juist ? onjuist & 64 & 53 & juist ? onjuist & 37 & 95 & juist ? onjuist \\
\hline 23 & 12 & juist ? onjuist & 65 & 54 & juist ? onjuist & 38 & 96 & juist ? onjuist \\
\hline 24 & 13 & juist ? onjuist & 66 & 55 & juist ? onjuist & 39 & 97 & juist ? onjuist \\
\hline 25 & 14 & juist ? onjuist & 67 & 56 & juist ? onjuist & 40 & 98 & juist ? onjuist \\
\hline 26 & 15 & juist ? onjuist & 68 & 57 & juist ? onjuist & 41 & 99 & juist ? onjuist \\
\hline 27 & 16 & juist ? onjuist & 69 & 58 & juist ? onjuist & 42 & 100 & juist ? onjuist \\
\hline 28 & 17 & juist ? onjuist & 70 & 59 & juist ? onjuist & 43 & 101 & juist ? onjuist \\
\hline 29 & 18 & juist ? onjuist & 71 & 60 & juist ? onjuist & 44 & 102 & juist ? onjuist \\
\hline 30 & 19 & juist ? onjuist & 72 & 61 & juist ? onjuist & 45 & 103 & juist ? onjuist \\
\hline 31 & 20 & juist ? onjuist & 73 & 62 & juist ? onjuist & 46 & 104 & juist ? onjuist \\
\hline 32 & 21 & juist ? onjuist & 74 & 63 & juist ? onjuist & 47 & 105 & juist ? onjuist \\
\hline 33 & 22 & juist ? onjuist & 75 & 64 & juist ? onjuist & 48 & 106 & juist ? onjuist \\
\hline 34 & 23 & juist ? onjuist & 76 & 65 & juist ? onjuist & 49 & 107 & juist ? onjuist \\
\hline 35 & 24 & juist ? onjuist & 77 & 66 & juist ? onjuist & 50 & 108 & juist ? onjuist \\
\hline 36 & 25 & juist ? onjuist & 78 & 67 & juist ? onjuist & 51 & 109 & juist ? onjuist \\
\hline 37 & 26 & juist ? onjuist & 79 & 68 & juist ? onjuist & 52 & 110 & juist 7 onjuist \\
\hline 38 & 27 & juist ? onjuist & 80 & 69 & juist ? onjuist & 53 & 111 & juist ? onjuist \\
\hline 39 & 28 & juist ? onjuist & 12 & 70 & juist ? onjuist & 54 & 112 & juist ? onjuist \\
\hline 40 & 29 & juist ? onjuist & 13 & 71 & juist ? onjuist & 55 & 113 & juist ? onjuist \\
\hline 41 & 30 & juist ? onjuist & 14 & 72 & juist ? onjuist & 56 & 114 & juist ? onjuist \\
\hline 42 & 31 & juist ? onjuist & 15 & 73 & juist ? onjuist & 57 & 115 & juist ? onjuist \\
\hline 43 & 32 & juist ? onjuist & 16 & 74 & juist ? onjuist & 58 & 116 & juist ? onjuist \\
\hline 44 & 33 & juist ? onjuist & 17 & 75 & juist ? onjuist & 59 & 117 & juist ? onjuist \\
\hline 45 & 34 & juist ? onjuist & 18 & 76 & juist ? onjuist & 60 & 118 & juist ? onjuist \\
\hline 46 & 35 & juist ? onjuist & 19 & 77 & juist ? onjuist & 61 & 119 & juist ? onjuist \\
\hline 47 & 36 & juist ? onjuist & 20 & 78 & juist ? onjuist & 62 & 120 & juist ? onjuist \\
\hline 48 & 37 & juist ? onjuist & 21 & 79 & juist ? onjuist & 63 & 121 & juist ? onjuist \\
\hline 49 & 38 & juist ? onjuist & 22 & 80 & juist ? onjuist & 64 & 122 & juist ? onjuist \\
\hline 50 & 39 & juist ? onjuist & 23 & 81 & juist ? onjuist & 65 & 123 & juist ? onjuist \\
\hline 51 & 40 & juist ? onjuist & 24 & 82 & juist ? onjuist & 66 & 124 & juist ? onjuist \\
\hline 52 & 41 & juist ? onjuist & 25 & 83 & juist ? onjuist & 67 & & \\
\hline 53 & 42 & juist ? onjuist & 26 & 84 & juist ? onjuist & 68 & & \\
\hline
\end{tabular}




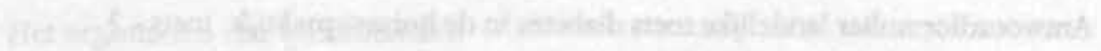

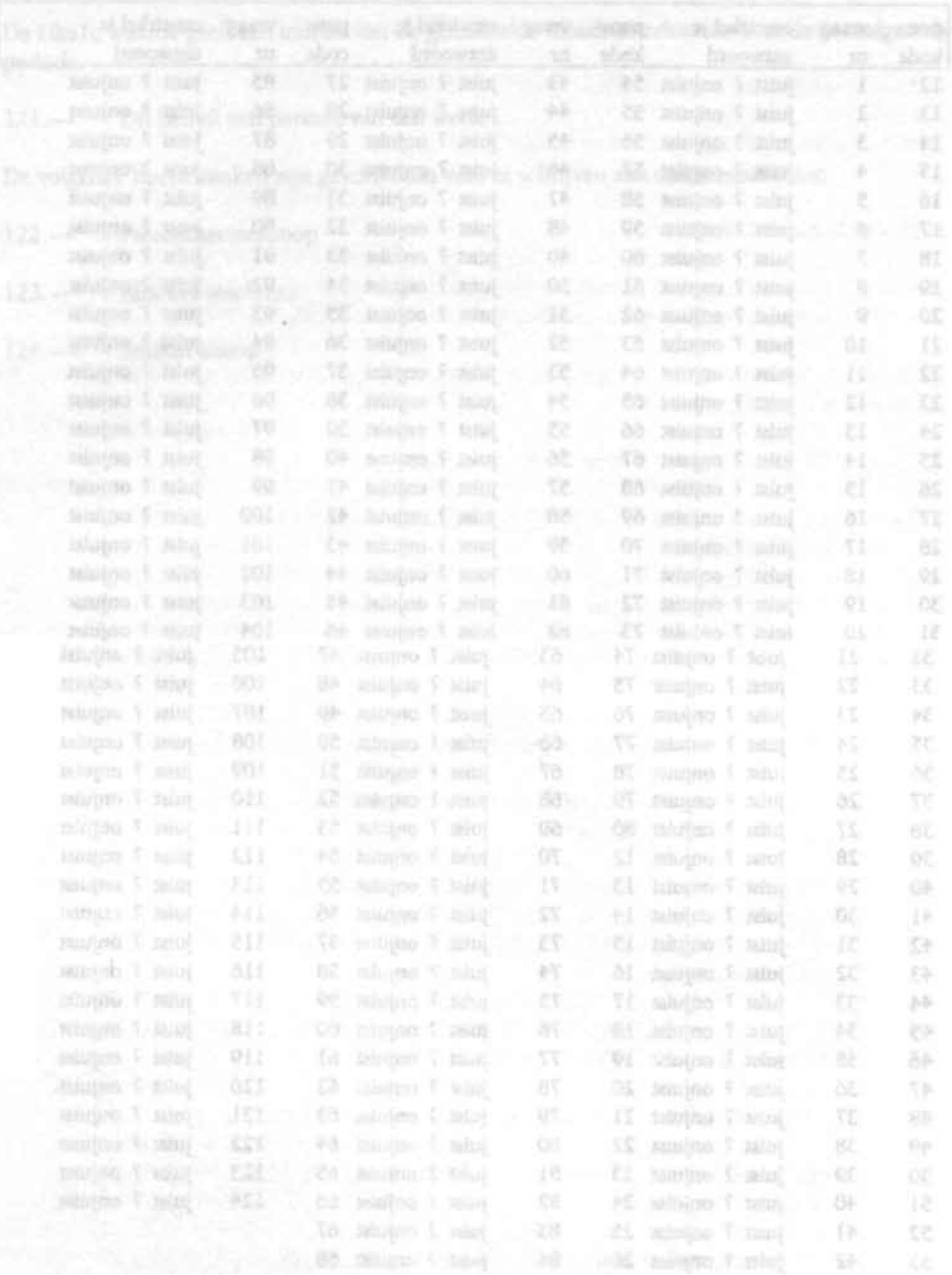




\section{Antwoordsleutel Diabetestoets 2}

\section{Casus 1}

1. juist

2. onjuist

3. juist

4. juist

5. juist

6. onjuist

7. juist

\section{Casus 2}

8. onjuist

9. juist

10. juist

11. juist

12. vervallen

13. juist

14. vervallen

15. onjuist

16. juist

17. onjuist

18. onjuist

\section{Casus 3}

19. onjuist

20. onjuist

21. juist

\section{Casus 4}

22. juist

23. juist

24. vervallen

25. juist

26. juist

27. juist

28. juist

Casus 5

29. juist

30. juist

31. juist

32. juist

Casus 6

33. onjuist

34. juist

35. onjuist

36. juist

37. juist

38. onjuist

39. onjuist

\section{Casus 7}

40. juist

41. onjuist

42. onjuist
43. onjuist

44. juist

45. vervallen

46. vervallen

Casus 8

47. juist

48. juist

49. onjuist

50. juist

51. juist

52. onjuist

53. juist

54. juist

Casus 9

55. juist

56. juist

57. juist

58. juist

59. vervallen

60. onjuist

61. onjuist

62. onjuist

63. juist

64. onjuist

65. juist

66. juist

67. onjuist

Casus 10

68. onjuist

69. juist

70. juist

71. juist

72. onjuist

Casus 11

73. juist

74. onjuist

75. vervallen

Casus 12

76. juist

77. onjuist

78. juist

79. juist

80. juist

Casus 13

81. juist

82. juist

83. onjuist

84. onjuist

85. juist
86. juist

87. onjuist

88. juist

Casus 14

89. juist

90. onjuist

91. juist

Casus 15

92. juist

93. vervallen

94. onjuist

Casus 16

95. juist

96. onjuist

97. juist

98. onjuist

99. juisi

100. onjuist

101. juis?

102. onjuist

Casus 17

103. juist

104. onjuist

105. onjuist

106. onjuist

107. juist

Aanvullende vragen

108. juist

109. juist

110. onjuist

111. juist

112. juist

113. onjuist

114. onjuist

115. onjuist

116. juist

117. onjuist

118. juist

119. juist

120. juist

121. onjuist

122. onjuist

123. juist

124. onjuist 


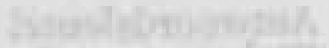

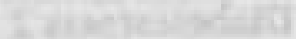
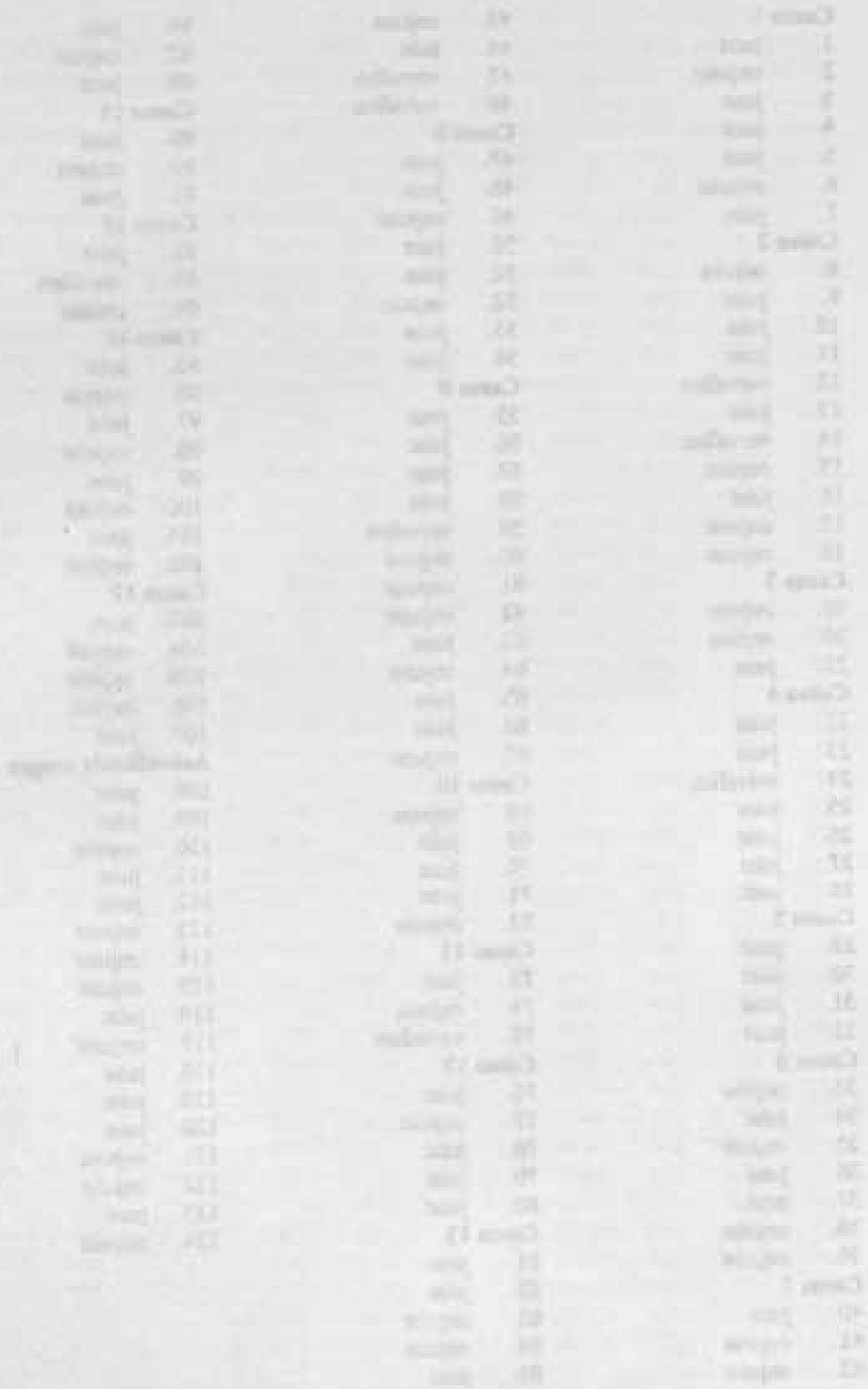


\title{
Kennispakket voor de behandeling van diabetes mellitus in de huisartspraktijk
}

\author{
2e druk
}

\author{
J. Zuidweg \\ Y.D. van Leeuwen \\ G. van Geldorp \\ L.H.C. Tan
}

Uitgegeven door de Stichting Diadata, onderwijsontwikkeling en onderzoek naar chronische aandoeningen in de eerste lijn.

Maastricht , 1988

Copyright 1988 @ Stichting Diadata,Niels Bohrstraat 15,6227 VT Maastricht

Tekstverzorging en lay- out: $O$.Sollet

Druk: Drukkerij De Heeg, Maastricht

CIP-gegevens Koninklijke Bibliotheek, Den Haag

Kennispakket

Kennispakket voor de behandeling van diabetes mellitus in de huisartspraktijk / ].Zuidweg ... [et al.].Maastricht: Stichting Diadata. - Tab. 2e druk

Met lit. opg.

ISBN 90-72468-01-5

SISO 605.16 UDC 616.379-008.64-085

Trefw.: suikerziekte in de huisartsgeneeskunde. 


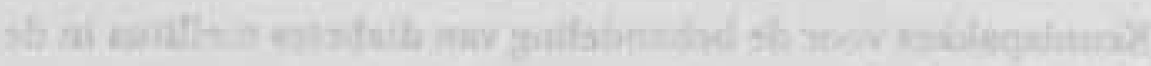
A(4) Th:

$\cos 45$

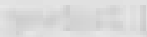

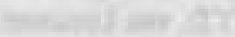

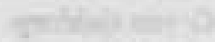

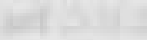

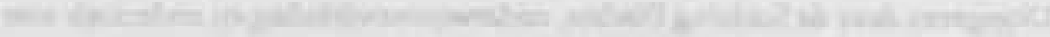

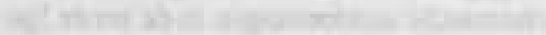

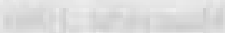

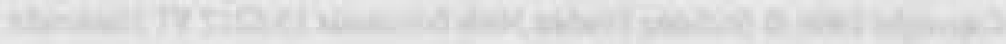

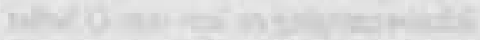

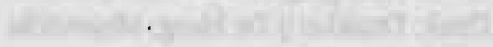

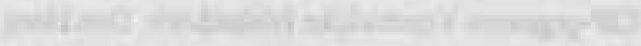

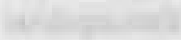

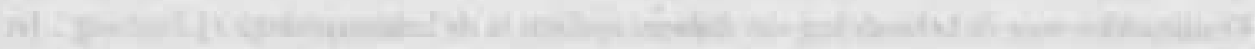

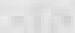

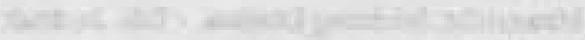
(n)

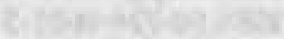

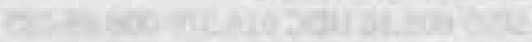

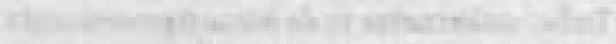


Hoofdstuk 1 algemeen

1.1 Epidemiologie en erfelijkheid

pag. 141

1.2 Classificatie

1.3 Diagnostische criteria voor diabetes mellitus

pag. 141

1.4 Protocol voor opsporing, diagnostiek en behandeling van type

II diabetes door de huisarts

Hoofdstuk 2 ontregeling

2.1 Oorzaken van acute ontregeling bij type I en II

2.2 Tekenen van hyper- en hypoglycaemie

2.3 Beleid bij ontregeling bij type I

2.4 Beleid bij ontregeling bij type II

Hoofdstuk 3 behandeling en begeleiding

3.1 Het dieet

3.2 Behandeling met orale bloedsuikerverlagende middelen

pag. 147

3.3 Overzicht van orale bloedsuiker verlagende medicatie

pag. 148

pag. 150

3.4 Geneesmiddeleninteracties bij diabetes mellitus

pag. 152

3.5 Voorlichting

3.6 Maatschappelijke aspecten

pag. 152

pag. 153

Hoofdstuk 4 late gevolgen van diabetes

4.1 Inleidende opmerkingen

pag. 155

4.2 Hypertensie

pag. 155

4.3 Oogcomplicaties

pag. 155

4.4 Neuropathie

pag. 157

4.5 Voetproblemen

pag. 157

4.6 Nefropathie

pag. 158

4.7 Huidziekten

pag. 159

Hoofdstuk 5 diabetes en zwangerschap

5.1 De zwailgere diabetespatiente

pag. 159

5.2 Het syndroom van de zwangerschapsdiabetes

pag. 159

Hoofdstuk 6 organisatie van de zorg voor diabetes patienten in de huisartspraktijk

6.1 Randvoorwaarden bij de behandeling van type IIdiabetes mellitus

pag. 160

6.2 Methoden van bloedsuikerbepaling in de huisartspraktijk

pag. 160

6.3 De $\mathrm{Hb}$ alc - en fructosaminebepaling

pag. 161

literatuur

pag. 16i

Dankbetuiging

pag. 165 
$1+1 \cdot x^{4}$

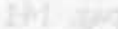

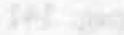

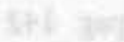

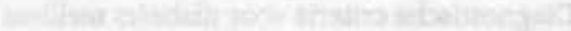

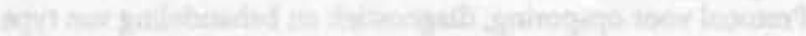

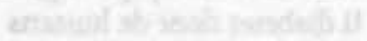

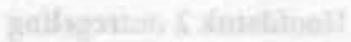

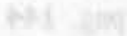

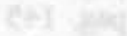

$3+1+2+1=$

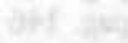

(4) than

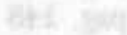

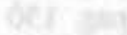

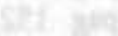

gath and

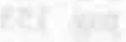

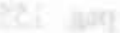

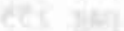

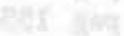

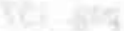

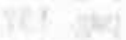

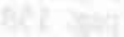

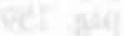

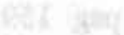

QCici nase

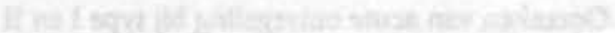

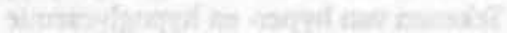

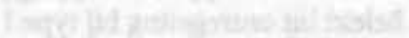

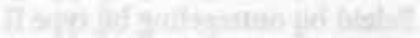

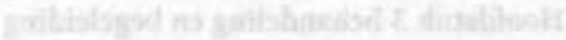

12 als Fis ran 25 Tans $4=$

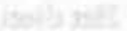

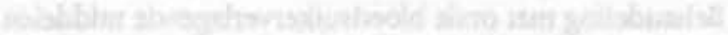

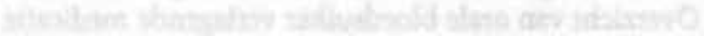

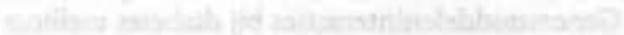

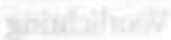

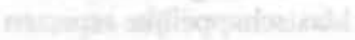
?.1. 2.

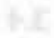
25 2.

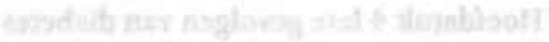

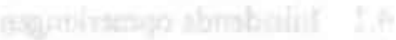

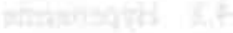

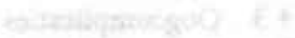

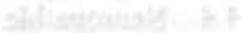
nowal la whingateks at

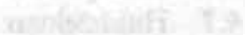

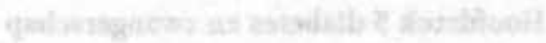

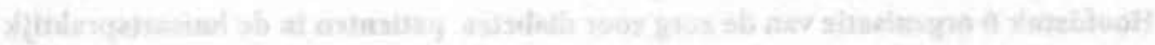

Why $10=0$

Cof $20=$

104. 4 tha

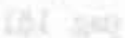

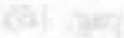

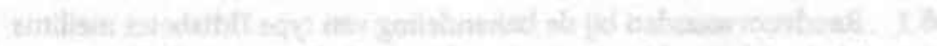

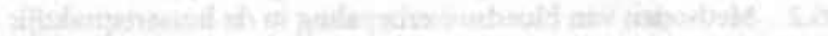
Ty=

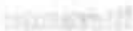




\section{Bij de eerste druk}

In 1984 ging het onderzoekproject 'Kennis en vaardigheid met betrekking tot patiènten met diabetes mellitus bij aanstaande huisartsen' van start aan het Instituut voor Huisartsgeneeskunde van de Universiteit van Amsterdam na subsidięring door de Stichting Researchfonds Diabetes Mellitus. Hoofddoelstelling van het onderzoek was het vaststellen van het niveau van kennis over diabetes mellitus bij artsen in opleiding aan de beroepsopleiding tot huisarts.

Om het onderzoeksdoel te bereiken was het noodzakelijk te beschikken over een omschrijving van de kennis die nodig is om patienten met diabetes mellitus te behandelen in de huisartspraktijk. Het hiertoe samengestelde kennispakket werd op basis van literatuur en na uitvoerig overleg met een tiental consulenten uit verschillende bij de diabetesbehandeling betrokken disciplines opgesteld.Daarnaast werden zes zeer ter zake deskundige huisartsen bereid gevonden om de eerste versies van het kennispakket kritisch te bekijken.

Bewust is gekozen voor nadruk op behandeling en begeleiding van de niet insuline afhankelijke diabetespatient (type II). Een tweetal taakomschrijvingen voor de huisarts, met name het L.H.V.basistaken-pakket (Springer, e.a. 1983), en het rapport 'Kenmerken van de huis-arts II' (van Es e.a. 1983) gaven richting aan deze keuze.

Het kennispakket fungeerde als basis waarop twee toetsen over diabetesbehandeling in de huisartspraktijk werden opgesteld. Deze toetsen werden in het kader van het onderzoek in 1985 en 1986 afgenomen bij deelnemers aan de beroepsopleiding tot huisarts aan de acht Nederlandse Universitaire Huisartsinstituten.Bij de nabespreking van de toetsresultaten met de artsen in opleiding bleek dat er behoefte bestaat aan een compact boekje over diabetes waarin de diabetesbehandeling vanuit huisartsgeneeskundig perspectief wordt beschreven. Hoewel het kennispakket in deze vorm niet bedoeld was als een kant en klare cursus diabetes voor huisartsen, kan het mogelijk in de gesignaleerde leemte voorzien.

Maastricht, zomer 1987

J. Zuidweg, huisarts, Maastricht

Y.D. van Leeuwen, huisarts, Vakgroep Huisartsgeneeskunde, Rijksuniversiteit limburg

G. van Geldorp, huisarts, Instituut voor Huisartsgeneeskunde, Rijksuniversiteit Utrecht.

L.H.C. Tan, socioloog, Instituut voor Huisartsgeneeskunde, Universiteit van Amsterdam

Bij de tweede druk

De uitgave van het Kennispakket blijkt in een behoefte te voorzien. In korte tijd vonden de eerste en de tweede oplage aftrek.

Tezelfdertijd startte het NHG haar standaardenreeks met de ontwikkeling van een diabetesstandaard. Dit feit en de snelle ontwikkeling op diabetesgebied hebben een herziening van de tekst nodig gemaakt. De criteria voor de diagnostiek werden aangepast aan de laatste WHO criteria, waarin de nuchtere bloedsuikerbepaling centraal staat. Verder vonden enkele kleine wijzigingen plaats.

Maastricht, april 1988

De auteurs 



\section{Algemeen}

\subsection{Epidemiologie en erfelijkheid}

Enige epidemiologische gegevens.

Er zijn in Nederland ongeveer 250.000 diabetespatiènten, onder te verdelen in circa een kwart type I en drie kwart type II diabetes mellitus. Dit betekent dat er in een praktijk van 2.500 patiênten ongeveer 10 type I en 30 type II diabeten te verwachten zijn.

Het voorkomen van diabetes in de bevolking neemt sterk toe met het stijgen van de leeftijd. Ongeveer $0.1 \%$ van de kinderen heeft diabetes; dit loopt op tot meer dan $6.5 \%$ in de groep van de 65-plussers. Een aanzienlijk deel van de type II diabeten is niet als zodanig bekend, omdat de aandoening vaak zonder klachten verloopt.

\section{Erfelijkheid.}

Het kind van een echtpaar, waarvan een van de partners type I diabetes heeft, heeft tien maal meer kans (namelijk een kans van een op twintig) om diabetes te krijgen, dan het kind van nietdiabetische ouders.

Type II diabetes is meer overerfelijk dan type 1 diabetes. Het is van belang om te weten of er in de famlie type Il diabetes voorkomt (familie-anamnese).

Type I en type II zijn als los van elkaar staande aandoeningen te beschouwen wat betreft overerving.

\subsection{Classificatie}

Type I of "Insuline Dependent Diabetes Mellitus' (= IDDM):

- bijna absoluut insuline tekort

- plotseling begin op jongere leeftijd

- sterke polyurie, polydipsie en vermagering

- neiging tot keto-acidose (dus acetonurie).

Type II of 'Non Insuline Dependent Diabetes Mellitus' (= NIDDM):

- relatief tekort aan insuline

- begint meestal pas na het 40ste jaar

- gaat meestal gepaard met overgewicht

- geen neiging tot keto-acidose (dus geen acetonurie).

\subsection{Diagnostische criteria voor Diabetes Mellitus}

De diagnose: 'Diabetes Mellitus' wordt gesteld op de nuchtere bloedglucosewaarde of op de bloedsuiker twee uur na de maaltijd.

Nuchtere Bloedsuiker 2 uur

bloedsuiker na KH-rijke maaltijd 
Mogelijk gestoorde

glucosetolerantie

Diabetes
: tussen 5.6 en $6.6 \mathrm{mmol}$ tussen $7.8 \mathrm{en} 11 \mathrm{mmol}$

$: \geq 6.7 \mathrm{mmol} \geq 11.1 \mathrm{mmol}$

Eén willekeurig bepaalde bloedsuiker van $11,1 \mathrm{mmol}$ of hoger is bewijzend voor diabetes! Een OGTT is dan niet meer nodig. De meeste diabetespatienten kunnen op deze manier worden gediagnostiseerd.

Bij uitslagen tussen 5,5 en $6,7 \mathrm{mmol}$ (nuchter) en tussen 7,8 en 11,1 mmol (twee uur na maaltijd) kan de bepaling herhaald worden of kan een orale glucose tolerantie test plaats vinden. Dit kan heel goed in de huisartspraktijk gebeuren.Bij de uitvoering van de orale glucosebelasting zijn een aantal criteria belangrijk (o.a. de samenstelling van de glucoseoplossing, 75 gram glucose opgelost in $300 \mathrm{ml}$ water, opdrinken binnen 3 minuten). Bij de interpretatie wordt alleen gelet op de nuchtere waarde en de twee uurs waarde na belasting.

Interpretatie van de orale glucose tolerantie test:

nuchtere bloedsuiker twee uurs waarde

Geen diabetes, $\quad: \quad<6.7 \mathrm{mmol}$ en $<7.8 \mathrm{mmol}$

Gestoorde

glucosetolerantie $\quad:<6.7 \mathrm{mmol}$ en tussen $7.8 \mathrm{en} 11 \mathrm{mmol}$

Diabetes $\quad: \geq 6.7 \mathrm{mmol} \mathrm{en} / \mathrm{of} \geq 11.1 \mathrm{mmol}$

De 'tussenwaarden' worden niet meer bepaald, behalve bij zwangeren.

Al deze waarden gelden bij bepaling in capillair bloed.

Urine-onderzoek op glucose als diagnostische test, voor diabetes en als onderdeel van de routine diabetescontrole is obsoleet, onbetrouwbaar en overbodig.

\subsection{Protocol voor opsporing, diagnostiek en behandeling van tyoe II diabetes door de huisarts}

Opsporing.

Bij klachten over moeheid, dorst, veel plassen, vermagering, jeuk in de genitaal streek, fluor albus moet de diagnose diabetes worden overwogen. Dit geldt ook bij recidiverende urineweginfecties en bij huidinfecties.

Verder kunnen de volgende klachten optreden als gevolg van een al langer bestaande diabetes:

- impotentie

- visusklachten

- pijn of tintelingen in armen en benen

- geisoleende neurologische uitvalsverschijnselen (o.a. n.facialis en n.abducens)

Deze symptomen kunnen de eerste aanleiding zijn om diabetes te overwegen. 
Heel vaak is er geen sprake van klachten.

Een verhoogd risico op diabetes of op het manifest worden daarvan, wordt gevormd door de aanwezigheid van:

- overgewicht

- familiair voorkomen van diabetes op oudere leeftijd

- zwangerschapsdiabetes in de anamnese

- gebruik van bepaalde medicatie die de glucosetolerantie veminderen, zoals corticosteroiden en thiazide-diuretica.

Gegevensverzameling, tevens jaarlijks controleschema.

$\mathrm{Na}$ het stellen van de diagnose is het zinvol om een aantal uitgangs-waarden vast te leggen door middel van:

\section{- Anamnese.}

Gevraagd dient te worden naar: welbevinden, dorst, polyurie, jeuk genitaliên, pijn en/of tintelingen in handen of voeten, sexuele stoornissen, visusklachten, angineuze klachten, claudicatie klachten, gewichtsverloop, problemen dieet, lichamelijke activiteit, rookgewoonte, medicatie.

- Uitgebreid lichamelijk onderzoek.

Dit bestaat uit: bepalen van lengte, gewicht, tensie, inspectie voeten; palpatie van de art. dorsalis pedes; APR.

- Aanvullend onderzoek.

Dit bestaat uit: onderzoek van de urine op eiwit; creatinine, cholesterol. Er dient een oogheelkundig consult plaats te vinden, tenzij de huisarts zelf het oogheelkundig onderzoek grondig beheerst. Elke diabeet heeft recht op een jaarlijks oogheelkundig onderzoek door een oogarts. Op indicatie:

- sediment of urinekweek

- Hb alc of fructosamine bepaling

Voorliching.

De voorlichting aan een diabetespatiènt moet de volgende, punten inhouden:

- Wat is suikerziekte, verloop, prognose, de behandeling.

- Rol van de voeding en gewicht.

- Uitleg van het belang van behandeling en belang van regelmatige controle.

- Uidleg van het belang van regelmatige lichaamsbeweging, b.v. fietsenof wandelen.

- Zonodig het dringende advies om, te stoppen met roken.

- Uitleg over late gevolgen.

- Instructie voetverzorging. Bij patiènten met tekenen van zowel ischemie als neuropathie is extra nadruk op voetverzorgingsadviezen van belang om amputaties te voorkomen

- Hoe te handelen bij ziekte. (Zeer belangrijk bij gebruikers van bloedsuikerverlagende medicatie)

- Uitleg over psychische en maarschappelijke gevolgen.

- Mogelijkhe:d van zelfcontrole.

- Lidmaatschap DVN.

Dit alles kan het beste gespreid over een aantal gesprekken plaatsvinden. 
Verder beleid.

Bij overgewicht doorsturen naar diettist.(Ook bij afwezigheid van overgewicht is inschakelen van een diêtist raadzaam. De begeleiding kan dan meestal in korte tijd worden afgerond.)Vervolgens afwachten hoe het gewicht zich normaliseert. Steeds nagaan of de gegeven informatie begrepen is, informatie herhalen en uitbreiden. Nagaan of de gegeven adviezen inpasbaar zijn in het dagelijks leven.

Bij bereiken streefgewicht of laagst haalbare gewicht (half jaar de tijd nemen!) nagaan of medicatie nodig is (bij een bloedsuiker twee uur na koolhydraatrijke maaltijd boven $10 \mathrm{mmol}$ en/of klachten en nuchter $>8 \mathrm{mmol}$ ). Eerst starten met tolbutamide, indien nodig te vervangen door een tweede generatie sulfonylureum preparaat.Indien dan nog geen adequate regulatie wordt bereikt, kan metformine worden toegevoegd. Lukt het dan nog niet, dan is instelling met insuline de aangewezen weg.

Er is de laatste tijd een duidelijke tendens zichtbaar bij endocrinologen om type II diabeten net zo strikt te gaan reguleren als type I diabeten (bloedsuikers zo dicht mogelijk bij het normale traject). Dit betekent dat de 'jonge' type II diabeten (40-60 jaar) veel sneller dan voorheen op insuline zullen worden ingesteld door de specialist.

Nagaan of zelfcontrole nodig en haalbaar is.

Bij stabiele toestand.

Controle schema met 3-maandelijks vooraf geagendeerde controle. Deze controle omvat een gesprekje over het algemeen welbevinden en eventuele klachten of problemen met het dieet. Er dient gevraagd te worden naar de gewichtsontwikkeling. Verder dient de voorlichting regelmatig herhaald te worden.Daamaast wordt de bloedglucosewaarde bepaald en het gewicht gecontroleerd. Eén keer per jaar uitgebreid lichamelijk onderzoek en aanvullend onderzoek herhalen.

\section{Ontregeling}

\subsection{Oorzaken van acute ontregeling bij type I en type II}

A. Bij type 1 diabetes:

Hyperglycaemie bij type I diabetes kan ontstaan door:

- te weinig insuline spuiten

- minder beweging nemen dan normaal

- infectie en andere intercurrente aandoeningen

- stress

- foute injectie-techniek

- te veel eten

Hypoglycaemie bij type I diabetes kan ontstaan door:

- te weinig of te laat eten

- meer beweging dan normaal nemen

- te veel insuline spuiten

- foute injectie-techniek

- alcoholmisbruik

B. Bij type Il diabetes: 
Hyperglycaemie bij type II diabetes kan ontstaan door:

- infectie en andere intercurrente aandoeningen, waaronder berucht zijn:

- CVA

" infarct

- stress

Hypoglycaemie bij type II diabetes kan onstaan door:

- interactie van orale bloedsuiker verlagende medicatie met andere geneesmiddelen

- overdosering van orale bloedsuiker verlagende medicatie

- overslaan van maaltijden bij gebruik van orale bloedsuiker verlagende medicatie

\subsection{Tekenen van hyper-en hypoglycaemie}

Tekenen van hyperglycaemie:

- slaperigheid

- moeheid

- dorst

- droge mond

- veel plassen

- jeuk

- bewustzijnsdaling, geleidelijk aan optredend

Teken van hypoglycaemie:

- hoofdpijn

- stemmingswisselingen, angst, onrust

- moeheid

- bleekheid

- hongergevoel

- zweten

- beven

- hartkloppingen

- slecht zien

- duizeligheid

- bewustzijnsdaling, snel optredend.

Er kan een beeld ontstaan dat veel lijkt op een CVA.

\subsection{Beleid bij ontregeling bij type I}

Hyperglycaemie.

Bij (infectie)ziekte dient altijd doorgegaan te worden met insulinetoediening, ook al eet de patiēnt minder of braakt hij/zij. De insuline-behoefte neemt namelijk toe bij ziekte. Dit geldt ook bij stresssituaties (bijv. examen, operatie). Bij koorts neemt de insuline-behoefte flink toe. Met behulp van bloedglucose teststroken kan de regulatie gevolgd worden en zonodig bijgestuurd worden.

De urine moet gecontroleerd worden op ketonen. Bij ketonurie dient men ruggespraak te houden met een internist. Bij ophoging van de insuline-dosering kan met het beste kortwerkende insuline gebruiken in stapjes van $4 \mathrm{E}$.Bij twijfel is het raadzaam om tijdig ruggespraak te houden met de behandelend internist. Bij een hyperglycaemisch coma moet de patient met spoed ingestuurd worden. 
Hypoglycaemie.

De type I diabetespatient en zijn of haar huisgenoten kennen meestal de signalen die bij hem/ haar wijzen op een hypo. Als er nog geen bewustzijnsdaling is opgetreden is de behandeling eenvoudig: orale aanvoer van snel resorbeerbare koolhydraten (in de vorm van suikerklontjes of limonade of het voorzichtig in de mond aanbieden van jam gevolgd door een boterham). Bij gedaald bewustzijn kan er een aanzienlijk motorisch onrust en agitatie optreden. Dit maak een iv-injectie met glucose dan onmogelijk. Alternatief is een im-injectie van glucagon. Er moet een duidelijk resultaat binnen vijftien minuten optreden. Zo niet dan direct insturen.Glucagon werkt alleen bij patiênten die enige uren tevoren nog gegeten hebben. Als iv-toediening van glucose wel mogelijk is, moet de patiênt hierna zeer snel bijkomen. Dosering: $40 \mathrm{ml}$ glucose $50 \%$ of $80 \mathrm{ml}$ glucose $25 \%$. Meestal zal de patiênt lang voor de volledige dosis is toegediend al bijkomen. Treedt er geen bewustzijnsverbetering op, dan moet de patiént met spoed worden ingestuurd. Ook in deze situatie is het bepalen van de bloedsuiker m.b.v. strips een zeer waardevol diagnostisch hulpmiddel. Glucose-oplossing is beschikbaar in ampullen van $10 \mathrm{ml}$ (diverse concentraties) en injectie-flacons van $50 \mathrm{ml}$ (o.a. 50\%). Gezien de omvang van de toe te dienen dosis dient men te beschikken over $20 \mathrm{ml}$ spuiten met bijpassende dikke naalden. In verband met de benodigde ruimte voor dit materiaal is het aan te raden om een soort noodsetje voor de behandeling van hypoglycaemie samen te stellen en op een vaste plaats te bewaren. $\mathrm{Na}$ bijkomen altijd koolhydraattoevoer (bijv. limonadesiroop en boterhammen).

De type 1 patient met een hypo kan bijna altijd thuis blijven na het ontwaken.

\subsection{Beleid bij ontregeling bij type II}

\section{Hyperglycaemie.}

De niet-insuline afhankelijke diabeet kan door (infectie)ziekten naar de hyperglycaemie afglijden. De stress, door de ziekte veroorzaakt, verhoogt de insuline-behoefte. De ontregeling bij type II verloopt veel langzamer dan bij type I: het zal meestal pas na twee of meerdere dagen optreden.

Het grote gevaar dat bij type II patienten op de loer ligt is uitdroging. Dit betekent dat er nauwkeurig naar de vochttoevoer en hydratietoestand gekeken moet worden.

Braken - in combinatie met niet drinken - is een alarmsignaal. Een acetonurie maakt de indicatie voor verwijzing compleet.

Als altijd is de beoordeling van de klinisch toestand en het welbevinden van de patient het belangrijkst. Het aan huis bepalen van de bloedsuiker en het controleren van de urine op ketonen met cen strip is uiteraard een onontbeerlijke steun.

Een hyperglycaemisch coma of pre-coma is een indicatie voor spoedverwijzing, aangezien er dan uitgebreide metabole ontregeling is opgetreden. Door ziekte kan een type II diabeet insuline-afhankelijk worden.

Hypoglycaemie.

De medicatie is hier de hoofdschuldige. De tweede generatie sulfonylureum preparaten die sterker en langer werken dan de eerste generatie middelen, zijn berucht om hun soms moeilijk te couperen hypoglycaemisch effect (zie ook de tabel bij medicatie). Vooral in combinatie met andere geneesmiddelen (zie geneesmiddelen-interacties), met alcoholgebruik of verminderde voedselopname. Hypos bij type II kunnen erg hardnekkig zijn.

Therapie bij coma of pre-coma: 1 ampul glucagon im of sc, indien na 15 minuten geen duidelijk. resultaat dan glucose intraveneus. Dosering: $40 \mathrm{ml}$ glucose $25 \%$. Glucose oplossingen zijn 
beschikbaar in ampullen van $10 \mathrm{ml}$ (diverse concentraties) en injectie flacons van $50 \mathrm{ml}$ (o.a. 50 \%). Gezien de omvang van de toe te dienen dosis dient men te beschikken over minimaal $10 \mathrm{ml}$ spuiten of $20 \mathrm{ml}$ spuiten met bijpassende dikke naalden. Na bijkomen ruime toevoer van koolhydraten (limonade en boterhammen) en gedurende 24 uur goed laten controleren door huisgenoot of insturen als dit niet mogelijk is.

\section{Behandeling en begeleiding}

\subsection{Het dieet}

Het dieet is de hoeksteen van de diabetesbehandeling. Bij de type II diabetespatiènt is het vaak de enige therapie. Aangezien het gaat om het bereiken van een blijvende verandering in eet- en drinkgewoonten, is een op maat gesneden begeleiding door een diétist noodzakelijk. Het alleen maar overhandigen van een dieetvoorschrift zou als een kunstfout moeten worden aangemerkt.

Bij dieetbehandeling van type I diabetes worden de volgende doelen nagestreefd:

- het zoveel mogelijk voorkomen van klachten en late gevolgen.

- normalisering van het gewicht op geleide van het streefgewicht. Hierbij mag men als vuistregel uitgaan van de lengte in $\mathrm{cm}$. min 100. Bij vrouwen moet hiervan dan nog eens 10 \% worden afgetrokken. Dus een lengte van $170 \mathrm{~cm}$ levert een streefgewicht op van $70 \mathrm{~kg}$ voor mannen en $70-7=63 \mathrm{~kg}$ voor vrouwen. Een iets nauwkeurigere maat vormt de Quetelet index, die berekent wordt als $\mathrm{kg}$ (lengte in $\mathrm{m}$ )2. Een Quetelet index van $<27$ is een streefmaat.

- het zoveel mogelijk reguleren van de bloedsuiker in het normale traject.

Dit betekent dat er voor iedere patiêrit afzonderlijk gekeken moet worden naar gewicht en streefgewicht, bloeddruk, bewegingspatroon en rookgewoonte.

Goede regulatie eist een meer gelijkmatige aanvoer van energie dan met drie maaltijden te bereiken is. Daarom worden er meestal drie of vier tussenmaaltijden ingelast. De samenstelling van de voeding wijkt niet af van 'gezonde' voeding. Het vanouds geldende absolute verbod op suikerhoudende produkten kan op basis van recent onderzoek niet meer staande gehouden worden.

In procenten van de geleverde energie ziet een optimale verdeling er

als volgt uit:

$50-60 \%$ koolhydraten

$30-35 \%$ vetten

$10-15 \%$ eiwitten

Er is steeds minder behoefte aan suikervrije- en suikervervangende produkten, omdat deze vaak een aanzienlijke energetische bijdrage leveren. Dit geldt voor sorbitol, xylitol en fructose. Sacharine, cyclamaat en aspartaam zijn energievrij. Beperkı alcoholgebruik kan toegestaan worden, mits de calorische bijdrage in het dieet verdisconteerd wordt ( $\pm 70 \mathrm{kcal}$ per consumptie). Alcohol heeft een hypoglycaemisch effect, vooral bij een lege maag. De samenstelling van het voedsel lijkt belangrijk voor de glucose-resorptiesnelheid. Het lijkt erop dat vezelrijke: produkten de resorptie vertragen. De patient zal voorgelicht moeten worden over de doeleinden van het dieet; ook hier geldt dat goede voorlichting de therapietrouw verhoogt. 
Bij type II diabetes worden in feite dezelfde doelen nagestreefd als bij type I. Dit is begrijpelijk, omdat het optreden van complicaties niet zozeer gebonden is aan het type diabetes, maar meer aan het jarenlang rondlopen met verstoorde insuline- en glucose-spiegels. Echter, door de nog aanwezige insulineproduktie zijn er geen scherpe pieken en dalen in de glucose-curve zoals bij type L. Bij type II is er sprake van een relatief insuline tekort, de behoefte aan insuline is sterk toegenomen, waarschijnlijk door verminderde gevoeligheid van de receptoren in de perifere weefsels. Daarom is het geven van tussen-maaltijden meestal niet noodzakelijk bij type II.

Type II diabetes gaat meestal gepaard met overgewicht. Het is van groot belang dit overgewicht te normaliseren en daarna het streefgewicht te handhaven. Een patiênt met medicatie en overgewicht kan vaak na afslanken tot het streefgewicht de medicatie staken of drastisch verminderen. Regelmatige lichamelijke inspanning of sportbeoefening bevordert de glucose tolerantie en helpt bij het afvallen.

Het begeleiden van een patiént die bezig is met een vermageringspoging vereist geduld van de huisarts. Er mag best een half jaar tot een jaar over heen gaan. Hoge bloedsuikers kunnen daarbij geaccepteerd worden. Hulp van een diêtist is noodzakelijk. De patient heeft tijd nodig om te wennen aan zijn/haar dieetvoorschrift. Hij/zij moet als het ware leren 'spelen' met zijn/haar dieet. Pas als de dieetkundige mogelijkheden uitputtend zijn benut of als acute ontregeling dreigt, is gebruik van orale bloedsuikerverlagende medicatie aan de orde. $\mathrm{Na}$ een half jaar overleggen met de diétist voordat medicatie gestart wordt i.v.m. nog te verwachten gewichtsdaling. Het is goed te beseffen dat artsen weinig scholing hebben op het gebied van voeding.

Het volgen van een dieet brengt in het begin vaak problemen in de sociale contacten met zich mee. De patient wordt doorlopend met zijn aandoening geconfronteerd en moet zijn omgeving erover inlichten. Dit kan alleen soepel verlopen bij een goede acceptatie door de patiént van zijn/haar aandoening; daaraan kan goede begeleiding bijdragen.

Dietisten zijn in de eerste lijn werkzaam bij de kruisvereniging of vrijgevestigd. Leden van de kruisverenigingen worden aldaar gratis geholpen. Vrijgevestigde diêtisten worden niet vergoed door de ziekenfondsen.

\subsection{Behandeling met orale bloedsuiker verlagende middelen}

Dieettherapie is de eerste stap in de behandeling van diabetes. Medi-camenteuze behandeling bij type II diabetes komt pas aan de orde als alles is geprobeerd om gewichtsreductie te behalen en het dieet goed uitgebalanceerd is.

Behandelingsschema type II:

stap 1: gewicht optimaliseren, lichamelijke activiteit stimuleren

stap 2 : pas bij falen na 6 maanden - d.w.z. gewicht en/of bloedsuikerwaarden blijven te hoog kan medicatie gestart worden

Sulfonylureumverbindingen.

Als alles geprobeend is om gewichtsreductie te behalen en het dieet goed uitgebalanceerd is en voldoende lichaamsbeweging genomen wordt en de glucosespiegels nog te hoog blijven (zie schema), is er een indicatie om medicamenteus in te grijpen. De keuze is dan tussen de sulfonylureum-preparaten van de cerste generatie zoals tolbutamide of een preparaat van de tweede generatie zoals glibenclamide. Glibenclamide werkt sterker en langer dan tolbutamide. De preparaten van de eerste generatie - en wel die met een korte halfwaarde tijd-verdienen de 
voorkeur, omdat ze de minste kans geven op hypoglycaemie. Bij onvoldoende werkzaamheid kan alsnog worden overgeschakeld op een preparaat uit de tweede generatie.

Beslisschema starten of wijzigen medicatie:

Instelling:

bloedglucosewaarde goed aanvaardbaar slecht

nuchter $\quad<6.7 \mathrm{mmol} \quad<8 \mathrm{mmol} \quad>8 \mathrm{mmol}$

2 uur p.p. $\quad<9 \mathrm{mmol} \quad<10 \mathrm{mmol} \quad>10 \mathrm{mmol}$

Bij eenmaal daagse dosering, de medicatie 's ochtends laten innemen. Gestoorde lever- en nierfunctie vormen een contra indicatie. Het is belangrijk de patiënt uit te leggen dat de bloedsuiker gecontroleerd moet worden bij ziekte en/of misselijkheid en/of bij verandering van eetritme, omdat de medicatie dan soms moet worden aangepast. Alcoholgebruik versterkt de bloedsuikerverlagende werking.

Bijwerkingen van de sulfonylureumverbindingen zijn:

- misselijkheid

- sporadisch: huidreacties

- symptomen van hypoglycaemie (bij overdosering).

Hypoglycaemieér kunnen sluipend en symptoomarm optreden bij behandeling met sulfonylureumderivatın. Verder leidt gebruik van sulfonylureumpreparaten vaak tot gewichtstoename. Dit maakt nogmaal duidelijk dat de behandeling van type II diabetes met deze middelen in feite een zwaktebod is, aangezien gewichtsreductie bij bijna alle type II diabetespatienten het voornaamste doel van de behandeling is.

Metformine.

Naast de sulfonylureumverbindingen wordt in Nederland op beperkte schaal ook gebruik gemaakt van metformine (Glucophage(8) bij de behandeling van type II diabetespatiènten. Dit preparaat behoort tot de groep van de biguaniden. Deze groep is aan het eind van de jaren zeventig in diskrediet geraakt door de kans op het veroorzaken van lactaat-acidose. In Nederland is destijds een aantal biguaniden uit de handel genomen, alleen metformine is nog toegestaan.

Metformine werd destijds afgeraden voor toepassing in de huisartspraktijk. De laatste tijd vindt er een herwaardering plaats; er lijkt een rol voor dit middel te zijn bij de behandeling van type Il diabetespatiênten, vooral bij patiênten met overgewicht. In verband met de kans op lactaatacidose mag het middel ook alleen maar toegepast worden bij patiênten met overgewicht. Zoals boven vermeldt, dienen diabetespatiênten met overgewicht echter allereerst met dieet behandeld te worden.

Gestoorde lever- of nierfunctie vormen een contra-indicatie voor het gebruik van metformine evenals alcoholgebruik. Lever- en nierfunctie dienen regelmatig, bijvoorbeeld twee maal per jaar bepaald te worden. Bij intercurrente ziekten waarbij weefselhypoxie kan optreden, zoals bij decompensatio cordis of bij ernstige luchtweginfecties, moet het gebruik gestaakt worden wegens. de kans op lactaat ophoping.

Bijwerkingen van metformine zijn onder andere:

- misselijkheid 
- diarree

- metaalsmaak en

- afname van de eetlust.

Metformine is in combinatie met sulfonylureumpreparaten te gebruiken. Dit geeft een additief bloedsuiker verlagend effect. Als het met bovengenoemde medicatie niet mogelijk is om een adequate regulering te bereiken (steeds verhoogde glucosewaarden en/of klachten als moeheid, jeuk, polidipsie en polyurie), dient de patiênt ingesteld te worden op insuline.

Medicatieschema bij type II:

1. tolbutamide

bij falen: 2, een tweede generatie sulfonylureumpreparaat

bij falen: 3 a an de maximale dosering van 2 metformine toevoegen

bij falen: 4 . insuline therapie overwegen

\subsection{Overzicht van orale bloedsuiker verlagende medicatie.}

1. Eerste generatie sulfonylureumderivaten.

$\begin{array}{lll}\begin{array}{l}\text { generic } \\ \text { name }\end{array} & \text { handelsnaam } & \text { werkings- sterkte dosering } \\ & \text { duur } & \text { in uren }\end{array}$

\begin{tabular}{|c|c|c|c|c|}
\hline tolbutamide & Artrosin & $6-12$ & $500 / 1000 \mathrm{mg}$ & $\begin{array}{l}1-3 \times 500 \mathrm{mg} \\
1-2 \times 1000 \mathrm{mg}\end{array}$ \\
\hline 19: & Rastinon & $6-12$ & $00 \mathrm{mg}$ & $\begin{array}{l}1-3 \times 500 \mathrm{mg} \\
1-2 \times 1000 \mathrm{mg}\end{array}$ \\
\hline 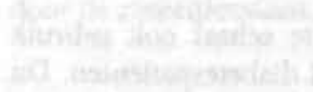 & Tolbet & $6-12$ & $500 \mathrm{mg}$ & $1-3 \times 500 \mathrm{mg}$ \\
\hline 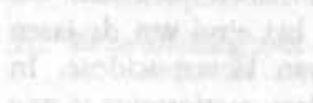 & Tolbutamidum & $6-12$ & $500 / 1000 \mathrm{mg}$ & $\begin{array}{l}1-3 \times 500 \mathrm{mg} \\
1-2 \times 1000 \mathrm{mg}\end{array}$ \\
\hline chloorpropamide & Chloronase & 48.60 & $250 \mathrm{mg}$ & $\begin{array}{l}1 \times 125 \mathrm{mg} \text { tot } \\
1 \times 500 \mathrm{mg}\end{array}$ \\
\hline hloorpropamide & 'Bochringer' & $48-60$ & $250 \mathrm{mg}$ & $\begin{array}{l}0 \mathrm{mg} \text { tot } \\
0 \mathrm{mg}\end{array}$ \\
\hline 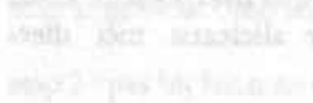 & Diabinese & $48-60$ & $250 \mathrm{mg}$ & $\begin{array}{l}1 \times 125 \mathrm{mg} \text { tot } \\
1 \times 500 \mathrm{mg}\end{array}$ \\
\hline tolazamide & Tolinase & $24-48$ & $250 \mathrm{mg}$ & $\begin{array}{l}1 \times 125 \mathrm{mg} \text { tot } \\
2 \times 500 \mathrm{mg}\end{array}$ \\
\hline acetohexamide & Ordimel & $12-24$ & $250 \mathrm{mg}$ & $\begin{array}{l}1 \times 125 \mathrm{rng} \text { tot } \\
3 \times 500 \mathrm{mg}\end{array}$ \\
\hline glycodiazine & Gondaíon & $24-48$ & $500 \mathrm{mg}$ & $1-3 \times 500 \mathrm{mg}$ \\
\hline
\end{tabular}


2. Tweede generatie sulfonylureumderivaten.

\begin{tabular}{lllll}
$\begin{array}{l}\text { generic } \\
\text { name }\end{array}$ & handelsnaam & $\begin{array}{c}\text { werkings- } \\
\text { duur } \\
\text { in uren }\end{array}$ & sterkte & dosering \\
\hline glibenclamide & Daonil & $12-24$ & $5 \mathrm{mg}$ & $\begin{array}{l}1 \times 2,5 \mathrm{mg} \text { tot } \\
3 \times 5 \mathrm{mg}\end{array}$ \\
\cline { 2 - 3 } & HemiDaonil & $12-24$ & $2,5 \mathrm{mg}$ & $1 \times 2,5 \mathrm{mg}$ tot \\
& Euglucon & $12-24$ & $5 \mathrm{mg}$ & $3 \times 5 \mathrm{mg}$ \\
& Semi-Euglucon & $12-24$ & $2,5 \mathrm{mg}$ & $1 \times 2,5 \mathrm{mg}$ tot \\
& & & $3 \times 5 \mathrm{mg}$
\end{tabular}

3. Biguamiden

$\begin{array}{lll}\text { generic } & \text { handelsnaam } & \text { werkings- sterkte dosering } \\ \text { name } & \text { duur } & \\ & \text { in uren } & \end{array}$

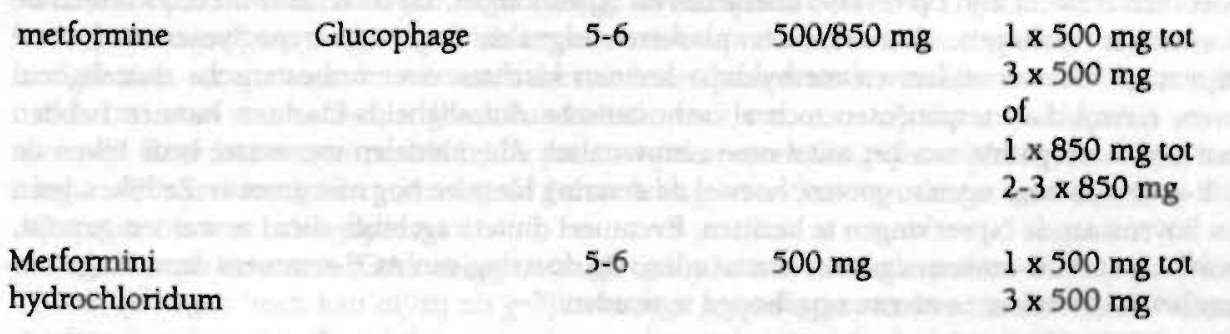

4. Insuline

Er is een duidelijke trend waarneembaar om patiênten met type II diabetes, die met dieet en medicatie niet goed in te stellen zijn, over te zetten op insuline. Het gaat dan meestal om relatief magere patiénten, die nog niet hoogbejaard zijn. Het lijkt belangrijk om met name verhoogde suikers 's nachts omlaag te krijgen. Dit is meestal met een een tot twee maal daags. insuline toedieningsregime te realiseren. Een zwaarwegend argument om niet tot insuline toediening over te gaan was en is gelegen in de praktische en psychische problemen rondom het 
spuiten. Sinds kort zijn er echter nieuwe toedieningssystemen beschikbaar, de zgn. insulinepennen, waarmee een deel van de praktische problemen aanzienlijk minder zwaar gaan wegen. Het voert binnen het bestek van dit boekje te ver om hier verder op in te gaan. Voordat patiênten op insuline worden ingesteld, dienen zij zichzelf te kunnen controleren d.m.v. bloedsuikerstrips in combinatie met een aflees-apparaat. Steeds meer ziektekosten verzekeraars vergoeden zelf-controle materiaal. Op dit moment valt het instellen van type II diabeten op insuline buiten het takenpakket van de huisarts.

\subsection{Geneesmiddeleninteracties bij diabetes mellitus}

Diverse, veel gebruikte, geneesmiddelen veroorzaken bij diabetes bijwerkingen of interactie met hypoglycaemica.

Bloedsuikerverhogende geneesmiddelen:

- gluco-corticolden

- thiazide-diuretica bijv. chloortalidon (Hygroton®) cave combinatie preparaten.

Bloedsuikerverlagende stoffen:

- beta-blokkers bemoeilijken de compensatiemechanismen bij optreden van hypoglycaemie en maskeren de symptomen van een hypo, vooral palpitaties.

- sulfonamiden cave combinatiepreparaten, onder andere trimethoprim-sulfamethoxazol (bijv. Bactrimelø en Eusaprim()

- salicylaten in hoge dosering

- lithium

interactie met sulfonylureum derivaten (versterkte bloedsuikerverlaging):

- tetracycline

- salicylaten

- fenylbutazon, oxyfenbutazon (o.a. Tanderil@)

- coumarinederivaten (antistolling)

- sulfonamiden cave combinatiepreparaten, o.a. trimethoprimsulfa.

Bij het kiezen van een preparaat voor de behandeling van hypertensie bij diabetespatiënten moet men bedacht zijn op diverse interacties en bijwerkingen. De thiazide-diuretica kunnen de bloedsuiker verhogen. Beta-blokkers maskeren signalen van een hypoglycaemie (vooral palpitaties). Vaatverwijders en methyldopa kunnen klachten over orthostatische duizeligheid geven, terwijl diabetespatiênten toch al orthostatische duizeligheids-klachten kunnen hebben door een neuropathie van het autonome zenuwstelsel. Als middelen van eerste keus lijken de ACE-remmers hoge ogen te gooien, hoewel de ervaring hiermee nog niet groot is. Ze lijken geen van bovenstaande bijwerkingen te bezitten. Eventueel diureticagebruik dient te worden gestopt,

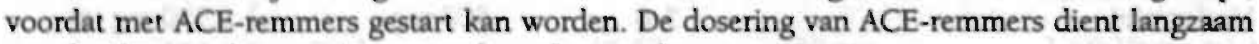
naar het best werkzame niveau opgehoogd te worden.

\subsection{Voorlichting}

Bij de voorlichting aan diabetespatiènten moet de huisarts aandacht besteden aan de technische en de psychosociale aspecten van het diabeet zijn. Dit wordt ook wel diabetes-educatie genoemd.

Het is belangrijk om eerst af te tasten of de patient open staat voor informatie. lemand staat niet open als hij angstig is of met allerlei vragen zit. Het tijdsperspectief van de arts is vaak op de 
toekomst gericht. De patiênt is veel meer bezig om het heden onder controle te krijgen. Als een patiènt met moeite bezig is te aanvaarden dat hij een chronische ziekte heeft, is hij er zeker niet aan toe om een verhaal over mogelijk complicaties na jaren aan te horen.

\section{Technische aspecten van het diabeet zijn.}

De technische informatie voor een type II diabetespatiênt zou de volgende punten moeten bevatten:

\section{Uitleg over:}

- het ziektebeeld

- de noodzaak van dieet

- de eventuele aanvullende therapie

- signalen van ontregeling

- bijzonder situaties, zoals ziekte, vakantie en reizen, beweging en sport

- de prognose en late gevolgen

- voetverzorging

- het controleregime

- bekijken of zelfcontrole nodig is (dit wordt vaak niet vergoed voor type II diabeten).

Psychosociale aspecten van het diabeet zijn.

Diabetes is een chronische aandoening, die in zijn beloop vaak lange periodes kent, die niet gepaard gaan met klachten. Een diabetespatient is niet als zodanig herkenbaar voor anderen.

Het zal duidelijk zijn dat het opvolgen van behandelingsvoorschriften bij diabetes nogal wat moeite kan kosten. De patiēnt incasseert de beloning voor vrij ingrijpende wijzigingen in zijn leefomstandigheden (verandering van eetgewoonte, rookgewoonte, levensritme etc.) niet in het heden maar in een ver weg gelegen toekomst.

Voor een optimale behandeling van diabetespatiênten is het aandeel daarin van de patiênt zelf van cruciaal belang. Om de compliance van de patiênt met de therapie zo hoog mogelijk te krijgen moet de huisarts het volgende goed voor ogen houden:

- op individueel niveau moet de patiênt zijn aandoening zo goed mogelijk leren accepteren. Dit acceptatieproces verloopt niet altijd even makkelijk. De huisarts kan hierbij behulpzaam zijn, alleen al door regelmatig te informeren naar de moeite die het de patiênt kost om zichzelf als 'suikerpatiênt' te zien.

- behalve op individueel niveau heeft menig diabetespatiênt heel wat weerstanden te overwinnen in zijn Maar omgeving. Diabetes heeft zowel praktische als emotionele gevolgen in de relatie met een partner. In contacten met anderen komen vaak onjuiste voorstellingen over diabetes naar voren. De patiènt schaamt zich vaak om voor zijn/haar aandoening uit te komen. Deze belevingsaspecten bij de patiênt spelen een belangrijke rol in het opvolgen van behandelingsvoorschriften. Het bij de behandeling betrek.ken van de eventuele partner van de patient is zeer belangrijk.

- als de acceptatie van de aandoening na enige tijd gelukt is en als de patiênt voldoende informatie gekregen heeft kan hij/zij als gelijkwaardige gesprekspartner van de arts bij de behandeling functioneren. Zowel de acceptatie van de aandoening als de inhoudelijke informatieoverdracht kunnen gestimuleerd worden als de patiênt lid wordt van de Diabetes Vereniging Nederland. Dit is elke: patiênt aan te raden.

\subsection{Maatschappelijke gevolgen van diabetes}

Diabetes en $\mu$ erk.

Vooral type I diabetespatiènten kunnen hinderpalen tegenkomen in de werksituatie. Zo is het hen niet toegestaan een groot rijbewijs te halen (vrachtwagen, bus). De mogelijke gevolgen van 
hypoglycaemie zijn bepalend voor het wel of niet geschikt geacht worden voor een baan. Factoren die hierbij meespelen zijn: onregelmatig werk, onvoorziene pieken in lichamelijk belasting, lange reistijden, veel stress. Het zal duidelijk zijn dat deze factoren per geval bekeken moeten worden, zo is het in bepaalde gevallen goed mogelijk dat een diabetespatiênt in ploegendienst blijft werken. Vaak kan het dieet en de medicatie aan de te verwachten omstandigheden worden aangepast.

\section{Diabetes en belasting.}

Het is mogelijk om ziektekosten op te voeren als aftrekpost voor de inkomstenbelasting: bijvoorbeeld extra kosten verbonden aan het dieet. Doordat het dieet in weinig meer afwijkt van de normale voeding, zal het niet eenvoudig zijn om extra kosten aan te tonen. Daarnaast is het mogelijk een vergoeding aan te vragen in het kader van de Algemene Arbeidsongeschiktheid Wet (AAW) voor bepaalde kosten, die diabetes met zich mee kan brengen.

\section{Diabetes en rijbewijs.}

Het C (vrachtwagen) en D (bus) rijbewijs wordt niet afgegeven aan insulinegebruikers. Bij verlenging van het rijbewijs boven de 70 jaar moet de diabeet bij de Eigen Verklaring, bij vraag 5 'ja' antwoorden. Op grond daarvan moet hij/zij een verklaring laten opstellen door een arts, die niet de eigen huisarts mag zijn.

Er zijn aparte formulieren bij het CBR te krijgen voor de keuring van diabeten. Men wil vooral geinformeerd zijn over de kans op hypos en de instelling gedurende de laatste tijd. Bij problemen kan een specialistische keuring worden verlangd, eventueel om het jaar.

Diabetes en levensverzekering en hypotheek. Diabetes wordt gezien als een verhoogd risico voor de verzekeraar. Dit komt tot uiting in verhoogde premies. Als men na het afsluiten van een levensverzekering diabetes krijgt, is het niet mogelijk premievrijstelling te krijgen (zoals in geval van invaliditeit).

De Diabetes Vereniging Nederland (DVN). De Diabetes Vereniging Nederland is een patiêntenbelangenvereniging. Er zijn 70 plaatselijke afdelingen actief.

Naast de uitgave van het maandblad Diabc - dat ook voor huisartsen informatief is - is er een reeks andere activiteiten, zoals het verstrekken van informatie (o.a. door middel van telefonische spreekuren en in de vortn van een grote reeks brochures), organisatie van reizen, inkoop en advisering over diabetesprodukten of hulpmiddelen.

Het lidmaatschap van de DVN kan de acceptatie door de diabetespatiênt van zijn/haar aandoening vergemakkelijken door contacten met lotgenoten en het beter geinformeerd zijn. De DVN geeft de laatste tijd in toenemende mate andacht aan de problematiek van de oudere diabetespatiènt.

Met haar 35.000 leden vormt de DVN een belangrijke gesprekspartner voor ieder die zich met de behandeling van diabetespatiênten bezig houdt.

Adres: Diabetes Vereniging Nederland

Postbus 933

3800 CC AMERSFOORT

Telefoon: $\quad$ 033-630566 


\section{Late gevolgen van diabetes}

\subsection{Inleidende opmerkingen}

De gevolgen van diabetes op langere termijn komen het duidelijkst tot uiting in het vaatstelsel.Het belangrijkst zijn de macro-angiopathie die tot uiting komt in de coronair vaten en de grote arteriele vaten van de benen en de micro-angiopathie die zijn sporen nalaat op de kleine arteriele vaten en capillairen van met name het netvlies, de nier, de voeten en het perifere zenuwstelsel. Zowel type 1 als type II diabetes mellitus vormen een risicofactor voor atherosclerose. Diabeten ontwikkelen meer, vaker en eerder atherosclerose en hypertensie dan nietdiabeten. Dit hangt onder meer samen met afwijkingen in de vetstofwisseling zoals een verhoogde cholesterol- en triglyceride spiegel, gestoorde thrombocytenfunctie, verminderde fibrinolyse en de al genoemde risicofactor hypertensie. De type II diabeet heeft een twee keer zo grote kans op het krijgen van een fataal myocard infarct dan zijn 'gezonde' leeftijdsgenoot. Het al of niet optreden van de genoemde complicaties kan overigens (nog) niet rechtstreeks afgeleid worden uit het wel of niet goed gereguleerd zijn in het verleden, hoewel het voor de microangiopathie praktisch zeker is dat goede instelling het optreden hiervan verminderd en vertraagd.

Diabetes is verantwoordelijk voor een groot deel van de amputaties van de onderste extremiteit.

Diabetes is de meest voorkomende oorzaak van blindheid.

$30 \%$ van de type I diabeten krijgt een terminale nierinsufficiêntie.

De verwachte levensduur op 30-jarige leeftijd is voor een type I diabeet een derde korter dan voor de rest van de populatie.

De leefijd van een type Il diabetespatiént is een belangrijk punt van overweging bij het beslissen tot behandeling en de keuze van de behandeling. Immers een aanzienlijkdeel van deze patiēnten is ouder dan 70 jaar op het moment van ontdekking. De winst van een optimale bloedsuikerregulatie - namelijk de hoop op het verminderen van de kans op boven-genoemde complicaties of het uitstellen daarvan - is voor deze leeftijdsgroep veel minder relevant dan voor jongere patiēnten met een langere te verwachten levensduur.Bij (hoog) bejaarden kan men dus een terughoudend behandelingsregime voeren.

\subsection{Hypertensie}

Met het oog op de late gevolgen van diabetes is de vroege opsporing en adequate behandeling van hypertensie van bijzonder groot belang. Hypertensie komt vaker voor bij diabetespatiênten dan in de 'gezonde' populatie, het is een risicofactor voor ischemische harziekten, nefropathie en retinopathie en cerebrovasculaire accidenten. De problemen bij de medicatie worden in de paragraaf over geneesmiddeleninteracties besproken.

\subsection{Oogcomplicaties}

Retinopathie.

Het optreden van diabetische retinopathie hangt samen met de leeftijd van de patient en de duur van de diabetes. Bij type I diabetes heeft $5 \%$ van de patiēnten na vijf jaar verschijnselen 
van diabetische retinopathie. Na twintig jaar is dit percentage opgelopen tot $75 \%$. Bij type. II heeft $25 \%$ van de patienten op het moment van ontdekking al een diabetische retinopathie.

Het beeld van de diabetische retinopathie ontstaat als gevolg van een gestoorde microcirculatie in het netvlies. De eerste waarneembare verschijnselen zijn veneuze dilatatie en micro-aneurysmata. In dit stadium zijn er meestal geen duidelijke klachten. Achteraf blijkt vaak dat er vage wisselende visusklachten geweest zijn. Het volgende stadium wordt gekenmerkt door het optreden van kleine intra-retinale bloedingen vanuit de beschadigde capillairen. In dit stadium zijn er ook harde exsudaten zichtbaar in de fundus. Dit zijn wit-gele ophopingen van eiwitachtig materiaal en lipiden, vaak ringvormig in de fundus gegroepeerd. Op door ischemie aangetaste plaatsen kunnen de zogenaamde zachte of cottonwool exsudaten ontstaan. Deze bestaan uit gezwollen axonuiteinden. Ze zijn helder wit en vlokkig. Bovengenoemde stadia vallen onder de noemer exsudatieve-, non-proliferatieve- of background-retinopathie. Na 5 jaar is ongeveer $15 \%$ van deze patiènten blind.

Als de șlechte voeding van het netvlies maar lang genoeg bestaat, kan er vaatnieuwvorming optreden. In eerste instantie gebeurt dit in de retina, maar dit kan ook vanuit de retina naar voren gaand in de glasvochtruimte optreden. Door verbindweefseling kan dit leiden tot vaatruptuur. Deze rupturen kunnen zich uiten als pre-retinale bloedingen tussen het netvlies en het corpus vitreum. Dit stadium wordt proliferatieve retinopathie genoemd. Hierbij treden vaak ernstige visusklachten op. Tenslotte kan het komen tot netvliesscheuren, de ablatio retinae. Deze treden vaak op in de maculastreek. Hierdoor onstaat tijdelijke of blijvende blindheid. Deze proliferatieve fase kan in korte tijd zeer expansief verlopen. Na 5 jaar is ongeveer de helft van deze patienten blind.

In de exsudatieve fase zijn de afwijkingen meestal perifeer gelocaliseerd, zodat de patiênt er nauwelijks hinder van heeft. Een eerste klacht is het zien van vlekjes, vlokjes of gordijnen, vaak gedurende korte tijd. Het volgen van diabetische retinopathie door middel van directe en indirecte fundusscopie is het werk van de ooggarts, tenzij de huisarts zelf de fundusscopie goed beheerst. Met behulp van de indirecte fundusscopie kan de periferie van de retina bekeken worden. Dit is met directe fundusscopie nauwelijks mogelijk. Verder kan men bij indirecte fundusscopie wat gemakkelijker manoevreren, waardoor het bijvoorbeeld nog mogelijk is om de fundus te onderzoeken bij lichte vormen van cataract. Voor pupilverwijding kan men gebruik maken van tropicamide oogdruppels. Deze diuppels zijn verkrijgbaar in kleine flacons voor eenmalig gebruik (zgn. nninimis). Vooraf dient de diepte van de voorste oogkamer beoordeeld te worden, in verband met de (kleine) kans op een acute glaucoomaanval door mydriaticumgebruik bij een ondiepe voorste oogkamer.

De type i diabeet kan het beste - gezien het verloop van de retinopathie - vijf jaar na het onstaan van de diabetes naar de oogarts gaan. Bij de type II diabeet, die mogelijk op het tijdstip van het stellen van de diagnose al een retinopathie heeft, dient meteen een oogheelkundig onderzoek plaats te vinden. Bij vaatproliferatie kan de oogarts door middel van lasercoagulatie het proces tot staan brengen. De vaatnieuwvormingen worden vernietigd door de inwerking van de laser op het netvlies.

Froliferatieve retinopathie is een relatieve contra-indicatie voor antistolling.

Andere oogafwijkingen.

Bij diabetespatiênten komen verder ook de volgende aandoeningen vaker

en op jongere leeftijd voor dan bij niet-diabeten:

- cataract

- glaucoom 
- iridocyclitis en.

- wisselende refractie.

\subsection{Neuropathie}

Het begrip diabetische neuropathie omvat alle neurologische afwijkingen ten gevolge van diabetes. Het gaat om een heterogene groep aandoeningen, bestaande uit:

- polyneuropathie,

- mononeuropathie, de craniele zenuwen betreffend,

- mononeuropathie, de perifere zenuwen betreffend,

- autonome neuropathie.

Bij de polyneuropathie staan de klachten veroorzaakt door aantasting van sensibele zenuwen vaak op de voorgrond. De klachten zijn onder andere: tintelingen, prikkelingen, branderig gevoel, koud gevoel, moe gevoel, pijn van divers karakter (vaak 's nachts erger dan overdag) en nachtelijke krampen. Deze klachten zijn meestal gelocaliseerd in de benen soms (ook) in de armen, vaak bilateraal. Bij onderzoek moet gelet worden op: uitval van de sensibele kwaliteiten te weten de vitale kwaliteiten: temperatuur- en grove tastzin en de gnostische kwaliteiten: vibratiezin, positiegevoel en fijne tastzin.Daarnaast moet gelet worden op motorische uitvalsverschijnselen zoals krachtverlies en spieratrofie.De achillespeesreflex kan opgeheven zijn. Dit komt zoals bekend ook voor bij oudere mensen zonder diabetes.

De mononeuropathie dient van de polyneuropathie te worden onderscheiden, omdat oorzaak en prognose verschillen. Bij de mononeuropathie kan het gaan om een door druk veroorzaakte lesie van de nervus medianus, nervus ulnaris en nervus peroneus. Bij tijdig onderkennen en opheffen van de veroorzakende druk is de prognose goed.

Niet door druk veroorzaakte diabetische mononeuropathieên zijn onder andere: uitval van de nervus oculomotorius en de nervus abducens, die aanleiding geven tot de klacht 'dubbelzien'.Bij onderzoek moet gelet worden opptosis, gestoorde oogbewegingen en afwijkende stand van het oog

Bij neuropathie van het autonome zenuwstelsel kumnen de volgende functies aangedaan zijn: de blaasfunctie (retentie en overloopblaas), de maagontlediging, de darmfunctie (nachtelijke diarree), de sexuele functie (impotentie met behoud van libido bij de man), de zweetsecretie (droge, atrofische huid). Ook kan er orthostatische duizeligheid optreden als gevolg van autonome neuropathie. Dit is te diagnosticeren door de tensie in liggende en staande houding te meten. Het tijdstip van optreden van neuropathie hangt niet direct samen met de duur van de diabetes. Neuropathie kan een eerste verschijnsel van een nog niet ontdekte diabetes zijn.Als gevolg van autonome neuropathie kan een myocardinfarct pijnloos verlopen. Een echte therapie is er nog niet voor diabetische neuropathie.

\subsection{Voetproblemen}

De voeten van de diabetespatiènt lopen risico's die te maken heben met het optreden van de eerdergenoemde complicaties in het vaatstelsel en in het zenuwstelsel. Als er een infectie aan de voet optreedt, wordt de genezing bemoeilijkt door slechte circulatie. Het is voor de prognose belangrijk om een onderscheid te maken tussen de ischemische en neuropathische afwijkingen, hoewel er vaak sprake is van een combinatie van beide. Neuropathische problematiek heeft een veel betere prognose. 
Bij de ischemische afwijkingen moet gelet worden op claudicatieklachten, afwezigheid van perifere pulsaties, atrofische huid, blauwachtig of rood verkleurde huid, slechte capillary refill.

Aanwijzingen voor neuropathie zijn: aanwezige perifere vaatpulsaties, witte huid, soms wat oedeem, goede capillary refill, droge, soms schilferende huid. Daarnaast is het belangrijk om te letten op eeltplekken. Eeltvorming is een teken van verkeerde drukverdeling. Dit betekent vaak dat het schoeisel beter aan de vorm van de voet moet worden aangepast. Eelt mag niet 'bloedig' verwijderd worden. Beter is $3-5 \%$ salicyl $2-3$ dd aan te brengen. Een goede pedicure kan veel narigheid voorkomen (bij ingegroeide nagels, eeltvorming en likdoorns).

Bij een eenmaal opgetreden infectie van de voet moet men zorgvuldig te werk gaan. De lesie moet zo droog mogelijk behandeld worden,eventueel met Mercurochroom (1) of Betadine (1) (geen voetbaden!); soms is bedrust met vermijding van druk (dekenboog of iets dergelijks) nodig. Tevens moet de regulering gecontroleerd, c.q. aangepast worden. Bij neuropathische infectie c.q. ulcera wordt vaak weinig pijn aangegeven door de patiént.

\section{Patient instructies voor de voetverzorging:}

- inspecteer de voeten, ook tussen de tenen, dagelijks op blaren, wondjes en kloven

- was de voeten dagelijks, droog ze goed af en smeer ze in met olie (b.v. baby-olie)

- vermijd te warm of te koud water bij het wassen

- gebruik nooit een kruik

- draag goed zittende sokken, zonder stoppen; dagelijks verschonen

- inspecteer de schoenen regelmatig aan de binnenkant op oneffenheden, spijkers e.d.

- loop nooit op blote voeten

- gebruik geen elastische banden om de kousen op te houden

- knip de nagels van de tenen recht af

- verwijder niet zelf eelt of likdoorns, maar bezoek hiervoor een pedicure, die U vantevoren vertelt dat $\mathrm{U}$ diabetes heeft.

\subsection{Nefropathie}

Urineweginfecties, vaak asymptomatisch, komen 2 tot 4 maal zo vaak voor bij diabetespatiénten dan bij 'gezonden', zowel bij mannen als bij vrouwen. Na een ziekteduur van tussen de 20 en 30 jaar blijkt $30 \%$ van de type I diabetespatienten te overlijden aan diabetische nefropathie. Bij type II diabetes lijkt nefropathie zich minder vaak te manifesteren, mogelijk omdat de gemicldelde ziekteduur nu eenmaal korter is door het latere begin van de ziekte.

Nefropathie is een langzaam voortschrijdend proces van histologisch aantoonbare veranderingen in de glomerulus. Na jaren ontstaat er een micro-albuminurie die niet waarmeembaar is met de gangbare urinestick-methode. De micro-albuminurie gaat over in een intermitterende geringe, later continue, proteinurie, die wel met de urinestick kan worden aangetoond. In de: vijf jaar volgend op het verschijnen van aantoonbare hoeveelheden eiwit in de urine gaat de nierfunctie geleidelijk achteruit. Dit wordt onder andere weerspiegeld in een oplopend creatininegehalte en een afnemende creatinineklaring. Na deze periode blijkı een groot deel van deze patiènten een terminale nierinsufficiêntie te hebben ontwikkeld, waarna ze slechts door middel van dialyse in leven kunnen blijven. Er zijn aanwijzingen dat cen optimale bloedsuikerregulatie het optreden van proteinurie vertraagt. Het is van groot belang een eventuele hypertensie zeer strikt te reguleren. Er zijn aanwijzingen dat zelfs verhoging van de bloeddruk in het gebied onder de hypertensiegrenzen al indicatie voor behandeling vormt (b.v. verhoging van diastolische druk van 70 naar $85 \mathrm{~mm} \mathrm{Hg}$ ). 
Bij niet goed gereguleerde diabetes is er vaak een verminderde weerstand tegen infecties. Dit uit zich in het vaker voorkomen van infecties door stafylokokken, schimmels en gisten (folliculitis, stomatitis, vulvitis, balanitis, intertrigo, paronychia). Deze aandoeningen kunnen het eerste signaal van diabetes zijn. Er kan jeuk optreden, gegeneraliseerd of alleen peri-anaal of perivulvair. Bij gebruik van sulfonylureum derivaten kan een gegeneraliseerd exantheem optreden.

\section{Diabetes en zwangerschap}

\subsection{De zwangere diabetespatiênte}

De zwangerschap van een diabetespatiènte loopt een hele reeks risicols. Hiertoe behoren: verhoogde kans op congenitale afwijkingen, macrosomie, partus prematurus, intra-uteriene vruchtdood, geboortetraumas, neonatale metabole problemen, toxicose, pyelonefritis. Bij reeds bestaande retinopathie en nefropathie is er kans op verergering hiervan door de graviditeit. Het is belangrijk om al voor de conceptie optimaal geregeld te zijn (zou congenitale afwijkingen verminderen). Tijdens de hele zwangerschap moet de vrouw zeer nauwkeurig met insuline gereguleerd zijn. Hiervoor gelden strengere bloedsuikercriteria dan bij niet-zwangere diabetespatiênten. De huisarts kan dit beter aan de internist, c.q. de gynaecoloog overlaten. Diabetes vormt een medische indicatie voor een klinische bevalling.

\subsection{Het syndroom van de zwangerschapsdiabetes}

Zwangerschap kan een dermate grote verstoring van de glucosetolerantie geven (vooral vanaf het derde trimester) dat het beeld van de zwangerschapsdiabetes kan ontstaan (bij een voordien niet manifest diabetische vrouw). Dit verdwijnt per definitie binnen zes weken na de bevalling. Ongeveer $30 \%$ van deze patiénten zal later diabetes krijgen. De criteria voor het stellen van de diagnose zwangerschapsdiabetes zijn strenger dan de algemene criteria. Daarnaast moet er rekening mee worden gehouden dat de nierdrempel voor glucose tijdens de zwangerschap verlaagd is. Positieve reductie in de urine moet dus verder uitgezocht worden. Dit gebeurt door een orale glucose tolerantie-test met 75 gram glucose. Hierbij mag de nuchtere waarde niet boven de 5,5 mmol uitkomen, de twee uurs waarde moet lager dan 7,6 mmol en de hoogste. waarde lager dan $9,0 \mathrm{mmol}$ zijn.

Vrouwen met een verhoogde kans op de zwangerschapsdiabetes zijn degenen met:

- diabetes in de familie

- gestoorde gtt, cq diabetes tijdens eerdere zwangerschap

- spontane abortus in de anamnese

- hoog geboortegewicht van eerdere kinderen (boven de 4,5 kg)

- hydramnion bij eerdere zwangerschap

- leeftijd boven 35 jaar

- adipositas

- positieve dyscongruentie tijdens de zwangerschap

- glucosurie 


\section{Organisatie van de zorg voor diabetespatienten in de huisartspraktijk}

\subsection{Randvoorwaarden bij de behandeling van type II diabetes mellitus}

1 De huisarts dient zich te verdiepen in de diabetes behandeling en de voor hem/haar relevante. ontwikkelingen op dit terrein te volgen.

2 Technische voorzieningen, waarover men dient te beschikken:

- ketonuriebepaling d.m.v. strips

- bloedsuikerbepaling d.m.v. strips en afleesapparaat

- creatinine clearance nomogram

- Quetelet Index tabel.

\section{Toelichting:}

De ketonuriebepaling kan bij dreigende ontregeling goede dienst bewijzen om te voorkomen dat patiénten met hoge bloedsuikers zondermeer direct worden ingestuurd. Het kunnen verrichten van een bloedsuikerbepaling in de eigen praktijk heeft grote organisatorische voordelen voor zowel patiént als huisarts. Het bespaart de patiênt een extra gang naar de prikdienst en de huisarts een precieze afstemming op elkaar van tijdstip van bepaling en tijdstip van controle. Bij spoedgevallen tijdens diensten zijn de voordelen evident.

\section{Organisatie.}

Het verdient aanbeveling om alle afspraken voor vervolgconsulten voor diabetes controle direct na het voorafgaande consult te laten maken, waardoor de mogelijkheid van bewaking ontstaat. De praktijkassistente kan ingeschakeld worden bij de controles. Zij kan een deel van de controle direct voorafgaand aan het bezoek aan de arts uitvoeren. Te denken valt aan: gewicht opnemen, tensie opnemen, glucose prikken, urinecontrole. Op deze manier betrokken bij de diabeteszorg zal de praktijkassistente tevens gemakkelijker in staat zijn om uitvallers op te sporen.

\section{Samenwerking.}

De huisarts moet bereid en in staat zijn met de diêtist samen te werken. Concreet gezien betekent dit dat hij/zij een verwijsbrief aan de diêtist schrij̧t en hem inızage geefi in belangrijke gegevens als bloedsuiker- en cholesterolwaarde. De kwaliteit van de diabetes behandeling wordt verhoogd door met een vaste diétist te werken en goed op de hoogte te zijn van zijn werkwijze. Zo kan voorkomen worden dat de huisarts andere voedingsadviezen geeft dan de diêtist. Niet overeenstemmende voedingsadviezen zijn voor de patiênt verwarrend en voor de diétist erg hinderlijk. Door inschakeling van de diêtist kan de huisarts een deel van de patiénten-voorlichting over diabetes aan hem overdragen. De huisarts dient te weten wat hij/zij in de eigen werksituatie kan verwachten van de leden van de wijkverpleging, met name op het punt van voorlichting aan diabetespatiênten.

\subsection{Methoden van bloedsuikerbepaling in de huisartspraktijk}

Sinds enige tijd is het mogelijk om een redelijk nauwkeurige bloedsuikerbepaling op eenvoudige en snelle wijze in de praktijk of bij de patiênt aan huis te doen. Hierbij maakt men gebruik van teststroken al dan niet met afleesapparatuur (diverse merken). Zonder afleesapparatuur is de methode nogal grof. Veel verder dan te laag, redelijk en te hoog kan men niet komen; dit is overigens voldoende voor diagnostiek van acute ontregeling. Met afleesapparatuur 
(kosten tussen de fl $50,-$ en fl $300,-$ ) is de nauwkeurigheid veel groter. Vergeleken met een laboratoriumbepaling bedraagt de afwijking niet meer dan $10 \%(10 \mathrm{mmol} \mathrm{kan} 11 \mathrm{mmol}$ zijn; $20 \mathrm{mmol} 22 \mathrm{mmol}$ ). Bij gebruik van afleesapparatuur is het mogelijk om ook insuline afhankelijke patiènten te gaan controleren. De mogelijkheid voor het maken van dag en nachtcurves of glucosebelastingsproeven bestaat ook. De stripjes van een aantal merken kunnen namelijk 24 uur bewaard worden, voordat ze afgelezen hoeven te worden.

De prijs van deze bloedsuikerbepaling ligt rond de fl 1,50. Deze kosten worden niet vergoed aan de huisarts door het ziekenfonds.

Er zijn apparaatjes in de handel die op een praktisch pijnloze wijze in de vinger prikken (b.v. Autolet en Autoclix \pm (1 50,-).

\subsection{De Hb alc-en de fructosaminebepaling}

Sinds enige tijd is de $\mathrm{Hb}$ alc bepaling beschikbaar gekomen. Deze bepaling geeft een indruk over de gemiddelde bloedsuikerregulatie over langere tijd, \pm zes weken. Normale waarde: 6-8,5 $\%$. Bij hoge bloedsuikers gedurende langere tijd: $>8,5 \%$ (AZM Maastricht). Met deze bepaling wordt geen uitsluitsel verkregen over het optreden van incidentele pieken en dalen in de bloedsuikerspiegels. De bepaling blijkt goed te correleren met de nuchtere bloedsuiker. Voor de behandeling van type II patiènten lijkt de aanvullende informatie van de bepaling voor de huisarts gering. Wanneer de indruk bestaat dat een patiênt zich alleen vlak voor de bloedsuikercontrole goed aan het dieet houdt -het zogenaamde 'oppoetsen'- kan men dat vermoeden verifièren met de $\mathrm{Hb}$ alc bepaling.

Ook als er onduidelijkheid is over het goed volgen van een dieet of innemen van de medicatie over langere tijd kan door middel van deze bepaling een groter tijdsbestek bekeken worden dan met de bepaling van de bloedglucose mogelijk is. De bepaling is echter vrij prijzig ( $\pm \mathrm{fl} 50,-$ ). Zeer recent werd de fructosaminebepaling ontwikkeld, die mogelijk de $\mathrm{Hb}$ alc bepaling in de toekomst zal vervangen. De fructosaminebepaling geeft een inzicht in de regulatie over de laatste 2-4 weken. De prijs van deze bepaling bedraagt ook $\pm f 150,-$, maar zal in de toekomst lager worden.

\section{Literatuur}

* Goed toegankelijke publicatie, aanbevolen voor nadere oriêntering.

In buitenlandse publicaties en in. Patient Care wordt de bloedsuiker vaak in mg/dl opgegeven. 1 $\mathrm{mmol} / \mathrm{h}=18 \mathrm{mg} / \mathrm{dl}$.

* 1. Berkhout J, De patiênt met diabetes mellitus. In: Nieuw Kompas voor de huisarts, december 1984; IV 3: 1-8

2. Boerhaave cursus 'Huisarts en diabetes'. Leiden: september 1984

- 3. Cejka V, Diabetes mellitus. Bijblijven 1985; 1: 34-64

4. Clark CM e.a., Acute hypo- en hyperglycaemie. Patient Care 1987; vol. $14 \mathrm{nr}: 5$ : $32-43$. 
-5. Cluysenaar OJJ, Ziekte en dieet, H5 diabetes mellitus. Utrecht; Bunge, 1983

6. Coelingh Bennink H e.a., De diagnostiek van zwangerschapsdiabetes. Ned Tijdschr $\S$ Geneesk 1980; 124:254

7. Crebolder $\mathrm{H}$,Eijndhoven $\mathrm{M}$ van, De begeleiding van type II diabeten. Huisarts en Wetenschap 1986; 29: 16-19

- 8. Dankmeyer HF (red), Diabetes Voorlichting. Utrecht; Stichting Teleac, 1981

9. Dankmeyer HF, Diabetes Mellitus, een handleiding voor de praktiserende arts. Alkmaar, Boehringer Ingelheim 1982

10. Dornau C e.a., A community study of diabetes in Oxfordshire. J Royal Coll Gen Pract $1983 ; 33: 151-55$

11. Dujardin BCG e.a., Laboratoriumonderzoek van reflectometers voor diabetische zelf controle. Huisarts en Wetenschap 1987; 30: 207-209

- 12. Eppinga P, Leemhuis MP, De behandeling van hypertensie bij patiênten met diabetes mellitus. Ned.Tijdschr.Geneesk. 1985; 129: $2195-9$

- 13. Erkelens DW, Bloedsuikerverlagende middelen. Ned. Tijdschr. Geneesk. 1987; 131: 748-751

14. Es JC van, Melker RA de, Goosmann FCL, Kenmerken van de huisarts-II. Utrecht; Bohn, Scheltema $\&$ Holkema, 1983

15. Goldstein De e.a., glucosecontrole thuis en tijdens het spreekuur. Patient Care 1987; vol.14; nr. 2: 15-26

16. Grol R, Mesker P, Huisarts en toetsing. Nijmegen; NUHI 1984: 109-11

17. Heere L, Diabetes Mellitus en sport. Arts in beweging 1985; 3:1-3

18. Heine RJ. Schouten JA, Het diabetesdieet: Niet anders dan voeding voor gezonde meinsen. Ned.Tijdschr.Geneesk. 1984; 128: 1524-1528

19. Heine RJ. Wanneer moet ik een glucose tolerantie test aanvragen? Vademecum permanente nascholing huisartsen $1985 \mathrm{nr} .29$

20. Hem GK vd (red), Nefrologie. Utrecht; Bunge, 1983: $123 \mathrm{ev}$

21. Hiam R, The audit of diabetes mellitus in general practice. The practitioner 1982; 226 : 275-8

22. Horst F vd (red), Diabetes, ziek oi gezond. Assen: Van Gorcum, 1980

23. Horst F vd, Sociale en maatschappelijke acceptatie van diabetes. Voordracht 1982 . Ongepubliceerd. 
24. Horst F vd, Meulders W, Een beetje suiker. Een onderzoek onder oudere diabetespatienten. Maastricht; Rijksuniversiteit Limburg, 1982

25. Hulst SGTh, Is het medisch verantwoord dat insuline-afhankelijke diabeten aan sport doen? Vademecum permanenten nascholing huisartsen $1985 \mathrm{nr}, 29$

26. Jacobson AM, Leibovich JB, Psychological issues. In: Diabetes mellitus. Psychosomatics $1984 ; 25: 7-15$

27. Kaplan SA e.a., Diabetes Mellitus, Ann of Intern Med 1982; 96: 635-49

28. Keen $\mathrm{H}, \mathrm{Ng}$ Tang Fui S, The definition and classification of diabetes mellitus. Clin Endocrinol Metab 1982; 11:279-305

- 29. Kozak GP, Clinical diabetes mellitus. Philadelphia Saunders, 1982

30. Kuy A vd, Metformine: kind met badwater weggegooid. Pharm. Weekblad 1985; 120: 666-78

31. Lambert AE, De huisarts en de complicatie van diabetes, diabetische nefropathie. Patient Care 1984; febr: 40-6

32. Lamberts H, Morbidity in General Practice. Huisartsenpers, Utrecht 1984

33. Lyons TJ, Colwell JA, welk type diabetes? de toepassing van de hedendaagse indeling. Patient Care 1987; vol.14: nr. 1:8-15

34. Marble A, Krall LP ea, Joslin's diabetes mellitus. 12th ed, Philadelphia; Lea \& Farbiger, 1985

35. Michels RPJ, Consensusbijeenkomst: De diabetische voet. Utrecht CBO, 1985

* 36. Michels RPJ, Consensus 'diabetische voet'. Ned.Tijdschr.Geneesk. 1987; 131: 112

37. Moors JPC, Seks als je suikerziekte hebt. Huisarts en Wetenschap (H\&P) 1979; nr.3: 27-29

* 38. Mulder JD, Brand AD, Huisarts en diabetes mellitus type Il. Bijblijven 1985; 1: 65-73

* 39. Mulder JD, Terpstra J, Diabetes Mellitus. Practicum huisartsgeneeskunde. Utrecht; Bunge, 1981

40. Muller HK, Over het normale gewicht. Ned.Tijdschr.Geneesk. 1980; 124: 1873

41. Panzram G, Mortality and survival in type 2 diabetes mellitus. Diabetologia 1987; 30 : 123-131

42. Pennings-Van der Eerden L, Post M, Zelfzorg bij oudere diabetici. Utrecht: Vakgroep Algemene Gezondheidszorg en Epidemiologie, 1985

43. Pirart J, Diabetes mellitus and its degenerative complications. A prospective study of 4400 patients observed between 1947 and 1973. Diabetes Care may-june 1978; 1 
44. Pirart J e.a., Bloodsugar and diabetic complications. New Engl J of Med 1978; 298: 1149 ,

45. Plooij M, Orale bloedsuiker verlagende middelen. Hoechst Medication Service, Amsterdam 1986

46. Radder JK, De huisarts en de complicatie van diabetes, de diabetische voet. Patient Care; maart 1984: 14-22

- 47. Reitsma WD, Diabetes Mellitus. Alphen a/d Rijn: Ned.bibl.der Geneesk. deel 162, 1983.

48. Romm FJ e.a., Care Process and patient outcome in diabetes mellitus. Medical Care $1979 ; 17: 748-57$

49. Shun Feng C, Laboratory Tests in Diabetes Mellitus. NY Stat J of Med 1981: 1328-31

50. Smit PTh, De huisarts en de complicaties van diabetes, diabetische neuropathie. Patient Care januari 1984; 3-8

51. Springer M ea, L.H.V.-basistakenpakket voor de huisarts.Utrecht, 1983

- 52. Steiner G, Diabetes and Arteriosclerosis. Diabetes 1981; 30: 1-7

53. Vermes I, Cromme PVM, Zeyen LJJM, Veen EA van, Het fructosamine gehalte in serum: een alternatief voor het percentage geglycolyseerd hemoglobine als maatstaf voor de diabetes regulering. Ned.Tijdschr.Geneesk. 1986: 130: 542

- 54. Vraag en antwoordjournaal serie diabetes mellitus. Breda: Medical World Press, nr. 1-11, decernber 1982/september 1983

55. Walford $\mathrm{S}$, Home PD, Alberti KGHH, A laboratory trial of two new blood-glucose reflectance meters featuring automatic exteral calibration. Ann Clin Biochem 1984; 21 : $116-9$

56. Wee! C van, Tielenmans W, Diabetes Mellitus in een huisartspraktijk. Huisarts en Wetenschap 1981; 24: 13-17

57. Weel $C$ van, Zelst $P$ van, Diabetes Mellitus in een huisartspraktijk II. Huisarts en Wetenschap $1983 ; 26 ; 214-7$

58. WHO Diabetes Mellitus. W.H.O. Technical Report Series 1985, nr. 727

59. Wieling W, Cardiovascular autonomic neuropathy in diabetes mellitus (dissertatie); Amsterdam, 1983 


\section{Dankbetuiging}

Op deze plaats willen wij allen danken die geheel belangenloos en met veel enthousiasme als adviseur/commentator aan het tot stand komen van dit kennispakket hebben meegewerkt. Geen van hen is verantwoordelijk voor het geheel of onderdelen, aangezien de eerste auteur de eindredactie heeft gevoerd.

Leden huisarts expert panel:

J.Baggen,

J.Berkhout,

Prof.dr. EJ.A. Huygen,

Prof.dr. J.D. Mulder Dzn,

Prof.dr. C.Spreeuwenberg,

Prof.dr. C. van Weel,

Vakdeskundigen:

E.Beukers,

Prof.dr. G.Essed,

Mw. B.Heinemans,

Dr. L.Hogenhuis,

F. van der Horst,

P.Jacobs,

Dr. R.P.J. Michels,

Mw. M. van Mierlobensteyn,

Dr. A.Nieuwenhuyzen Kruseman,

Prof.dr. W.Reitsma, huisarts te Brunssum

huisarts, Rijksuniversiteit Limburg

huisarts, Katholieke Universiteit Nijmegen

huisarts, Rijksuniversiteit Leiden

huisarts, Vrije Universiteit Amsterdam

huisarts, Katholieke Universiteit Nijmegen.

internist-endocrinoloog, Academisch Ziekenhuis Maastricht

gynaecoloog, Academisch Ziekenhuis Maastricht

districtsverpleegkundige diabetes thuiszorg. Academisch Ziekenhuis Maastricht

neuroloog te Sittard

socioloog, Rijksuniversiteit Limburg

diêtist te Heerlen

internist-diabetoloog, A.M.C. Amsterdam

oogarts

internist-endocrinoloog, Academisch

Ziekenhuis Maastricht

intemist-endocrinoloog, Rijksuniversiteit Groningen 


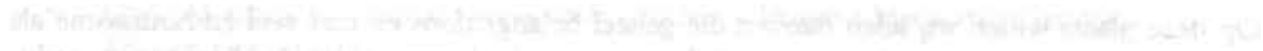

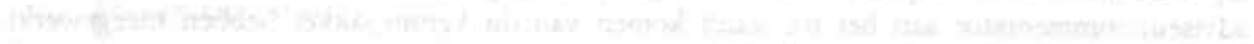

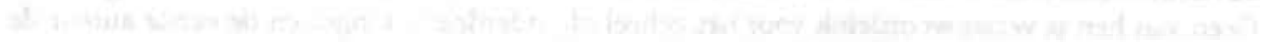




\section{Bijlage 4}

\section{Landelijke toets diabetes in de huisartspraktijk}

Vragenlijst instituutsgebonden onderwijs diabetes

Maastricht, juli 1987.

Geachte coördinator, geachte huisartsbegeleider,

Voor de afronding van het "diabetestoetsproject" zou ik graag meer willen weten over de aard en omvang van het op het instituut gegeven onderwijs m.b.t. diabetes mellitus aan de onderzochte haios.

Zou U daartoe deze vragenlijst willen invullen?

Deel I bevat 3 algemene vragen over Uw programma, deel II bevat 6 vragen over het onderwijs per onderzochte groep haios.

Bij voorbaat dank voor de te nemen moeite.

Jaap Zuidweg 


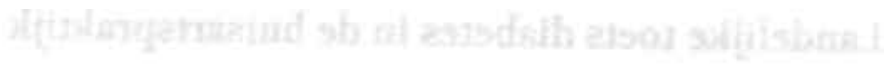

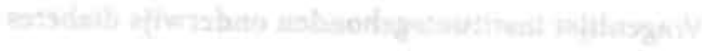




\section{I. algemeen}

1. Was er tijdens ons onderzoek (voorjaar $1985 \mathrm{~V} / \mathrm{m}$ voorjaar 1986) sprake van een reguliere onderwijsactiviteit m.b.t. diabetes in Uw opleidingsprogramma?
O ja
$\mathrm{O}$ nee

2. Zo ja, graag omschrijven wat betreft:

- soort activiteit

- tijdsomvang

- moment in het opleidingsjaar

3. Is de situatie nu anders dan zoals bovenomschreven?

O situatie 't zelfde

O situatie anders, namelijk

\section{2. vragen per groep}

Instiruut:

Groep:

Begeleider(s):

Uiteraard komt een onderwerp als diabetes in de huisarsopleiding meerdere keren ter sprake. lk zou echter graag willen weten in welke mate er expliciet aan dacht aan besteed is.

4. Heeft deze groep tijdens de beroepsopleiding gencht onderwijs gehad m.b.t. diabetes mellitus?

O ja

O nee

O onbekend/niet meer te achterhalen 
5. Zo ja, wanneer vond dit onderwijs plaats?

O bij de start van het opleidingsjaar (in de le of 2e maand)

$O$ in de $3 e t / m$ ge maand

$O$ na de $9 e$ maand

$O$ anders, namelijk

O niet meer te achterhalen

6. Wat was de omvang van de betreffende onderwijsactiviteit?
O 1 uur of minder
O 1 tot 2 uur
O 1 dagdeel
meer dan 1 dagdeel

7. Was het onderwijs eenmalig?
O ja, eenmalig
nee, meerdere keren en wel:
O onbekend maal uur met interval van weken

8. Wat voor soort activiteit betrof het? (meerdere antwoorden mogelijk)
O lezing
O een huisarts
O een specialist
$O$ een dietist
$\mathrm{O}$ anders, namelijk

O met een spreker van buiten de groep

O casuistiekbespreking, naar aanleiding van casus afkomstig uit

O referaat door groepslid/-leden

ongestructureerde groepsbespreking

$O$ anders, namelijk

$O$ onbekend/niet te achterhalen

9. Is de eerste afname van de landelijke diabetestoets ('rode boekje') in de groep inhoudelijk nabesproken?
O ja
O nee
O onbekend/niet meer te achterhalen

Hartelijk dank voor de genomen moeite! 


\section{Bijlage 5}

Aanvullende vragenlijsten deelnemers toets 1 en toets 2 en praktizerende huisartsen 


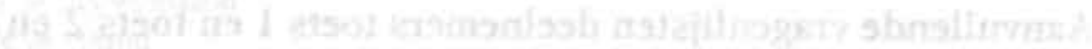

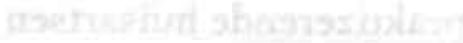


ponscode

Naam

Formulier

(4 t.m. 8)

Huisartsinstituut

Universiteit van

$(9,10)$

\section{Aanvullende vragen}

(s.v.p. cijfer o.ncirkelen)

a. Wat is je leeftijd?

- jonger dan 25 jaar

-25 tot 30 jaar

- 30 jaar en ouder

b. Wat is je geslacht?

- man

- vrouw

c. Hoelang geleden studeerde je af?

- minder dan tén jaar geleden

- 1 tot 2 jaar geleden

-2 tot 3 jaar geleden

- 3 jaar of langer geleden

d. Aan welke universiteit heb je het artsexamen afgelegd?

- Universiteit van Amsterdam

- Universiteit van Limburg

1

2

- Universiteit van Utrecht

3

- Universiteit van Groningen

4

- Universiteit van Leiden

- Universiteit van Nijmegen

- Universiteit van Rotterdam

- De Vrije Universiteit

8

- Overige: nl.

0

e. Heb je tussen het artsexamen en het begin van de beroepsopleiding tot huisarts als arts gewerkt? (meer antwoorden mogelijk)

- in een huisartspraktijk

- in een verpleeghuis

$1 \quad(15)$

- op een polikliniek Interne of

Afdeling Interne

2

- overige

3

- niet van toepassing

f. Hoeveel tijd heb je in het afgelopen jaar besteed aan het bestuderen van literatuur over diabetes mellitus?

- minder dan I uur

- 1 tot 2 uur

- meer dan 2 uur 
g. Heb je in het afgelopen jaar een nascholingscursus gevolgd over diabetes mellitus?
- ja van:
2 uur
eten dagdeel 2
twee dagdelen 3
- neen
4

(21)

h. Wordt in de huisartspraktijk van je opleider speciale aandacht besteed aan diabetespatienten (b.v. een diabetesspreekuur)?

$-j a$

1

(22)

- neen

2

begerroblodimat

Opmerkingen:

Met dank voor je medewerking! 


\section{Bijlage landelijke toets diabetes in de huisartspraktijk}

Naam

Verbonden aan Huisartsinstituut Universiteit van

\section{Aanvullende vragen}

1. Hoelang bent $u$ als huisarts werkzaam?
a. $<2 \mathrm{jr}$
b. $2-5 \mathrm{jr}$
c. $5-10 \mathrm{jr}$
d. $>10 \mathrm{jr}$

2. Werkt $\mathrm{u}$ in een
a. solopraktijk
b. associatie
c. groepspraktijk
d. gezondheidscentrum
e. anders

3. Wat is de grootte van de praktijk?
a. $<1500$ patiênten
b. 1500-2000 patiènten
c. 2000-2500 patiénten
d. 2500-3000 patiēnten
e. $>3000$ patiênten

4. Hoe schat $u$ het aantal bejaarden in uw praktijk? (gemiddeld is dit $12 \%$ )
a. ongeveer $12 \%$
b. veel lager dan $12 \%$
c. veel hoger dan $12 \%$
d. weet niet

5. Hoe worden patiẽnten met type Il diabetes mellitus in uw praktijk behandeld?
a. door u zelf
b. elders, b.v. bij de internist
c. er zijn geen type II diabetespatiênten in de praktijk

6. Besteedt u speciale aandacht aan patiênten met diabetes mellitus?
a. ja
b. nee

7. Hoeveel tijd heeft $u$ het afgelopen jaar besteedt aan het lezen over diabetes mellitus?
a. $<1$ uur
b. tussen 1 en 2 uur
c. $>2$ uur 
8. Heeft u gedurende de afgelopen twee jaar een nascholingscursus gevolgd over diabetes mellitus?
a. ja, van \pm 2 uur
b. ja, van \pm een halve dag
c. ja, van \pm teen dag
d. nee 


\section{Bijlage 6}

Resultaten eerste afname bij huisartsen-inopleiding, uitsplitsingen

\begin{tabular}{|c|c|c|c|c|c|c|c|c|c|}
\hline Rubriek & \begin{tabular}{|c|} 
Landelijk \\
gemiddelde
\end{tabular} & $\ln .1$ & In.2 & $\ln .3$ & $\ln .4$ & $\ln .5$ & $\ln .6$ & $\ln .7$ & $\ln .8$ \\
\hline 1 & 81 & 85 & 9 & $\pi$ & 8 & $\pi$ & 85 & $\pi$ & 81 \\
\hline SD & 12 & & & & & & & & \\
\hline 2 & 64 & 66 & 56 & 57 & 66 & 57 & 2 & 4 & 5 \\
\hline SD & 20 & & & & & & & & \\
\hline 3 & 99 & $\mathbf{9 8}$ & 65 & 5 & 58 & 53 & as & 52 & 62 \\
\hline SD & 19 & & & & & & & & \\
\hline 4 & 68 & $\theta$ & 75 & $\pi$ & 79 & 0 & 8 & 50 & $\pi$ \\
\hline SD & $\sigma$ & & & & & & & & \\
\hline 5 & 66 & GA & $n$ & a) & $\pi$ & 61 & $\pi 0$ & 56 & 65 \\
\hline SD & 16 & 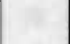 & H & 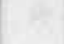 & & & & & \\
\hline 6 & 63 & 67 & 67 & 4 & 65 & 5 & a3 & 55 & $\theta$ \\
\hline SD & 10 & & & & & & & & \\
\hline 7 & 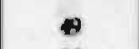 & 52 & 4 & 46 & $\theta$ & 4 & 5 & $\omega$ & $\mathbf{5}$ \\
\hline SD & 16 & 4 & $n$ & int & 4 & & & & \\
\hline 8 & 12 & (1) & 45 & $\omega$ & 4 & 30 & 4 & 39 & 4 \\
\hline SD & 19 & & & & & & & & \\
\hline 9 & 51 & 46 & 9 & 51 & G & 45 & 60 & 0 & 61 \\
\hline SD & 21 & - & & & & & & & \\
\hline $\begin{array}{l}10 \\
\text { SD }\end{array}$ & $\begin{array}{l}51 \\
18\end{array}$ & 54 & 52 & 44 & 53 & 4 & 56 & 46 & 57 \\
\hline Tot. toets & 60 & 62 & 63 & 58 & 63 & 54 & 64 & 53 & 63 \\
\hline SD & 8.7 & 8.1 & 7.7 & 8.5 & 7.8 & 9.0 & 7.0 & 7.3 & 6.7 \\
\hline
\end{tabular}




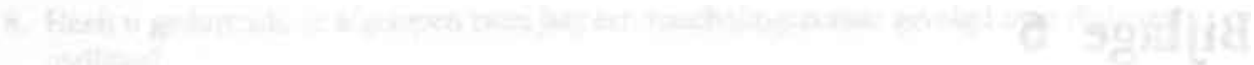

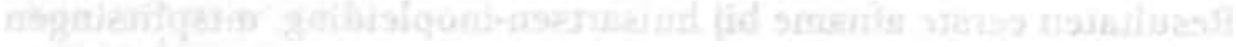

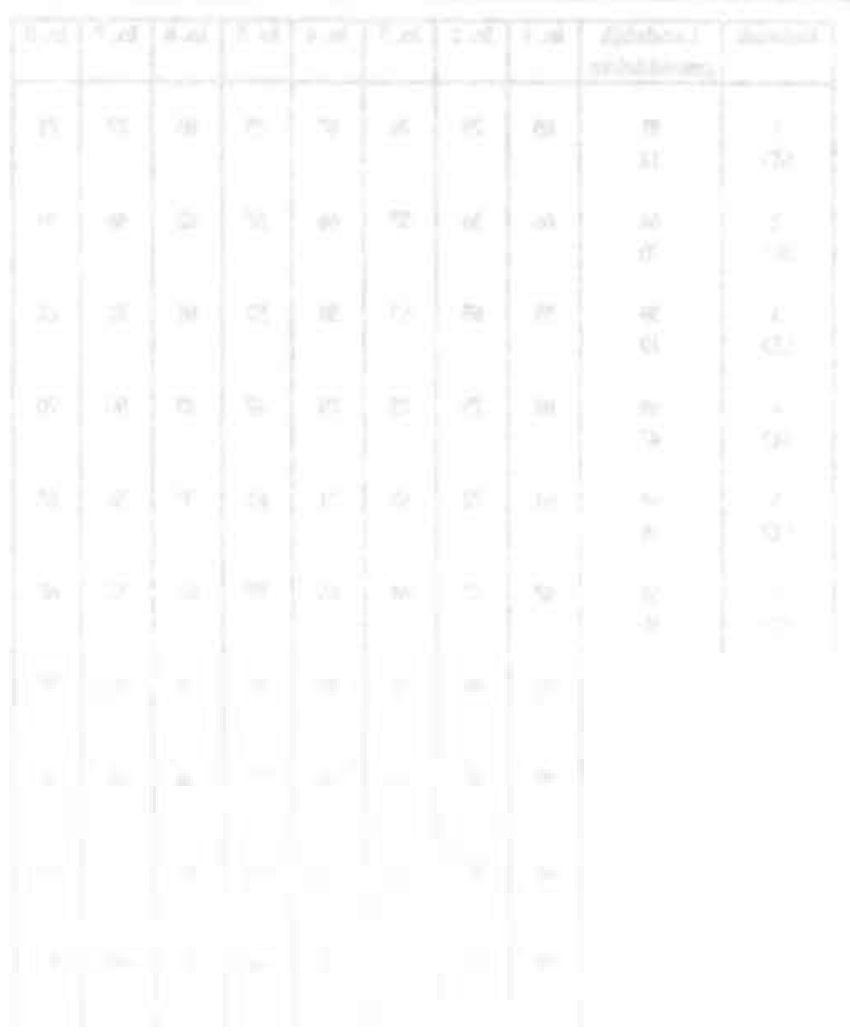


Bijlage 7

Resultaten tweede afname bij huisartsen-inopleiding, uitsplitsingen

\begin{tabular}{|c|c|c|c|c|c|c|c|c|c|}
\hline Rubriek & $\begin{array}{l}\text { Landelijk } \\
\text { gemiddelde }\end{array}$ & $\ln .1$ & In. 2 & In. 3 & $\ln .4$ & $\ln 5$ & $\ln .6$ & $\ln .7$ & $\ln .8$ \\
\hline 1 & 78 & 78 & 81 & 7 & 75 & $\pi$ & 78 & 73 & 84 \\
\hline $\mathbf{S D}$ & 11 & & & & & & & & \\
\hline 2 & 64 & 64 & 54 & 66 & 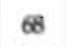 & 64 & 68 & 62 & 73 \\
\hline $\mathbf{S D}$ & 18 & & & & & & & & \\
\hline 3 & 67 & 64 & 74 & 58 & $\pi$ & 64 & $n$ & 65 & 73 \\
\hline SD & 15 & & & & & & & & \\
\hline 4 & 80 & 72 & 88 & 62 & 87 & 79 & 84 & 81 & 8 \\
\hline $\mathbf{S D}$ & 24 & & & & & & & & \\
\hline 5 & 79 & 78 & 84 & 79 & 79 & 80 & 80 & 73 & 78 \\
\hline$\Phi$ & 12 & & & & & & & & \\
\hline 6 & $\pi$ & $\theta 8$ & $\pi$ & $\Leftrightarrow$ & $\pi$ & 7 & 73 & 67 & 77 \\
\hline $\mathbf{S D}$ & 10 & & & & & & & & \\
\hline 7 & 68 & 66 & 72 & 66 & 64 & 64 & $\pi$ & 61 & 75 \\
\hline$\Phi D$ & 13 & & & & & & & & \\
\hline 8 & 60 & 99 & 54 & 58 & 65 & 55 & 61 & $\theta$ & 70 \\
\hline$\Phi$ & 20 & & & & & & & & \\
\hline 9 & 65 & 67 & 66 & 64 & 61 & 61 & 65 & 60 & 66 \\
\hline $5 D$ & 19 & & & & & & & & \\
\hline 10 & 63 & 59 & 68 & 64 & 65 & 64 & 64 & 57 & 68 \\
\hline$S D$ & 17 & & & & & & & & \\
\hline Tot toet & 70 & 68 & 72 & 68 & $\theta$ & 68 & 72 & 66 & 76 \\
\hline SD & 8.1 & 67 & 50 & 6.7 & 6.9 & 9.9 & 6.7 & 10.4 & 92 \\
\hline
\end{tabular}




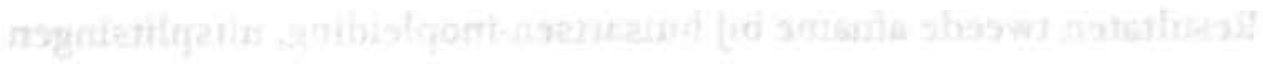

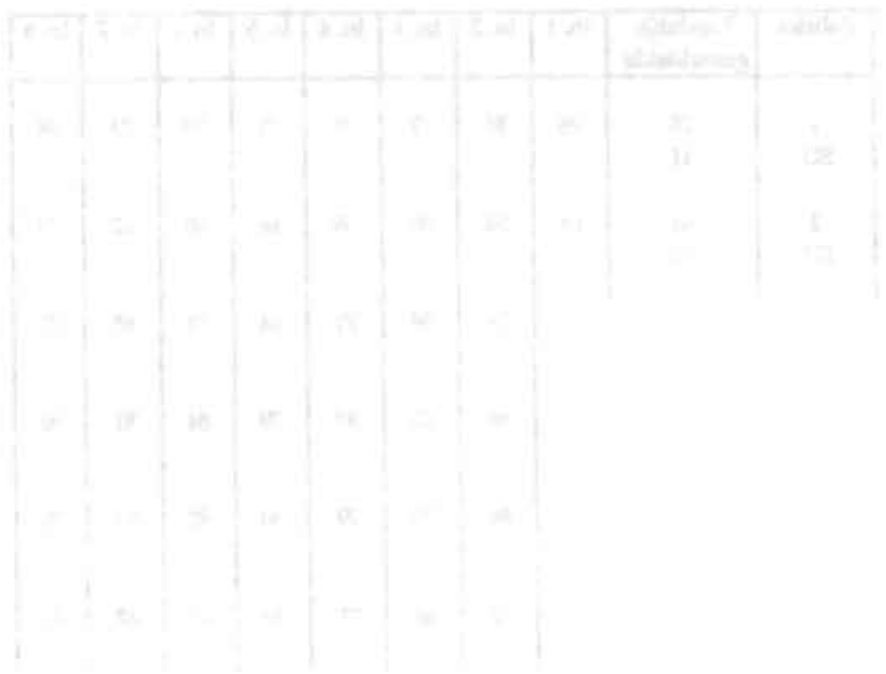




\section{Bijlage 8}

toename in kennis gedurende de huisartsopleiding per instituut, uitsplitsingen

Resultaten instituut 2 per rubriek

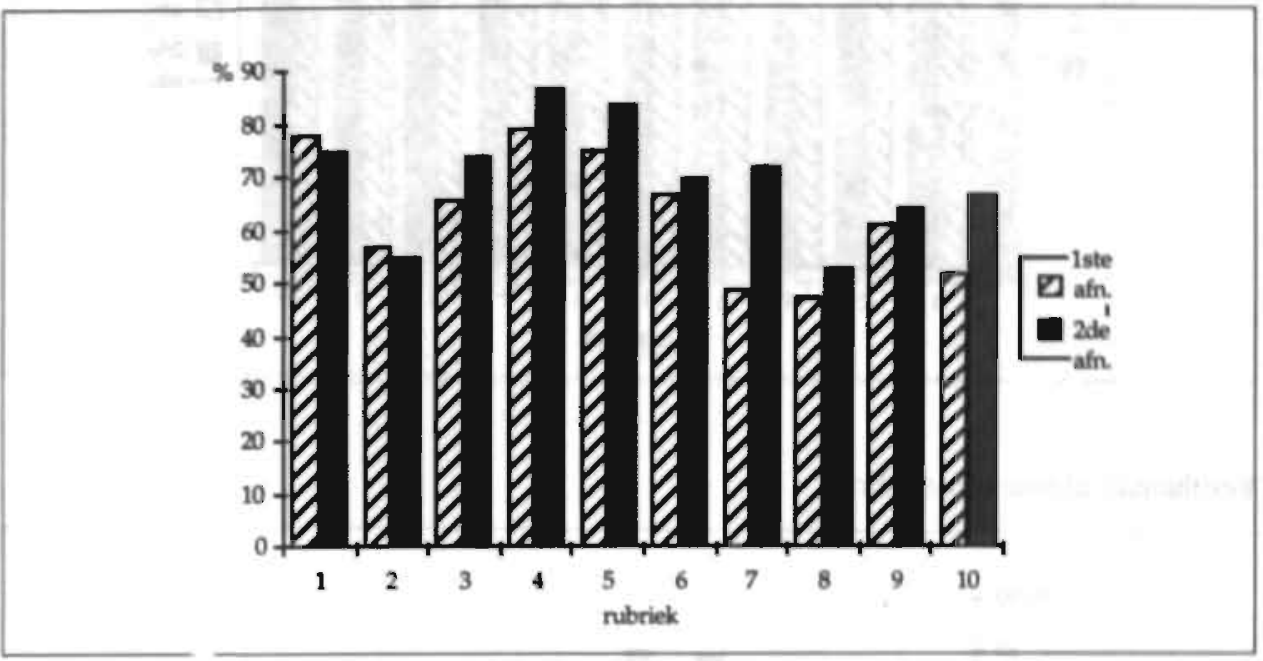

Resultaten instituut 3 per rubriek

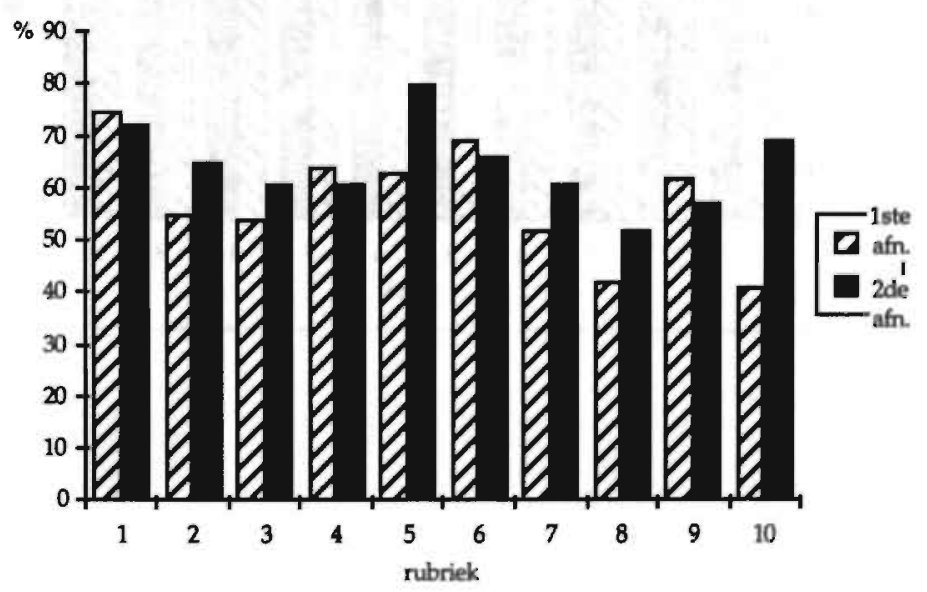




\section{Resultaten instituut 4 per rubriek}

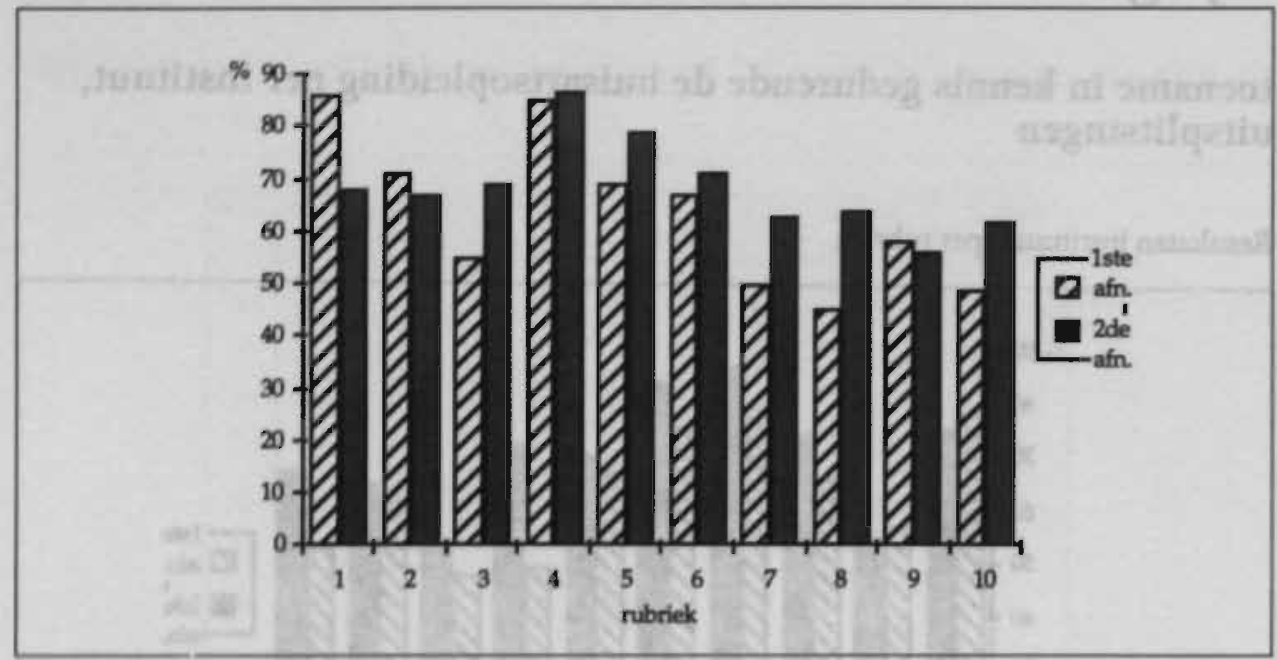

Resultaten instituut 5 per rubriek

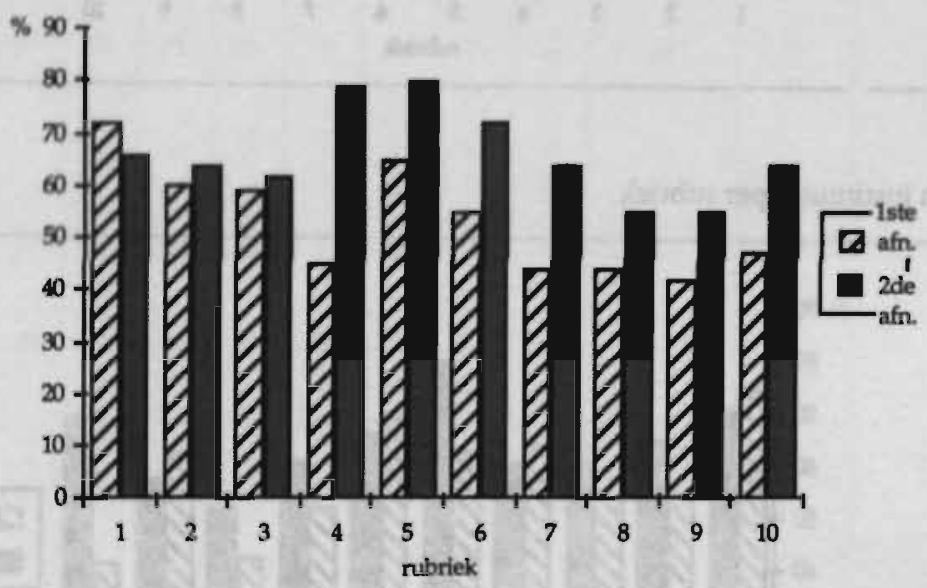


Resultaten instituut 8 per rubriek

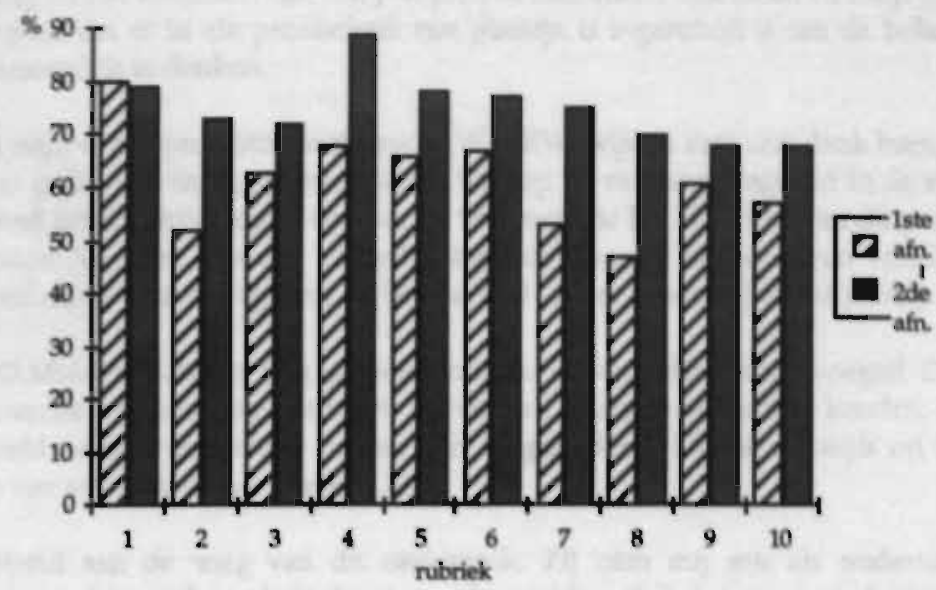




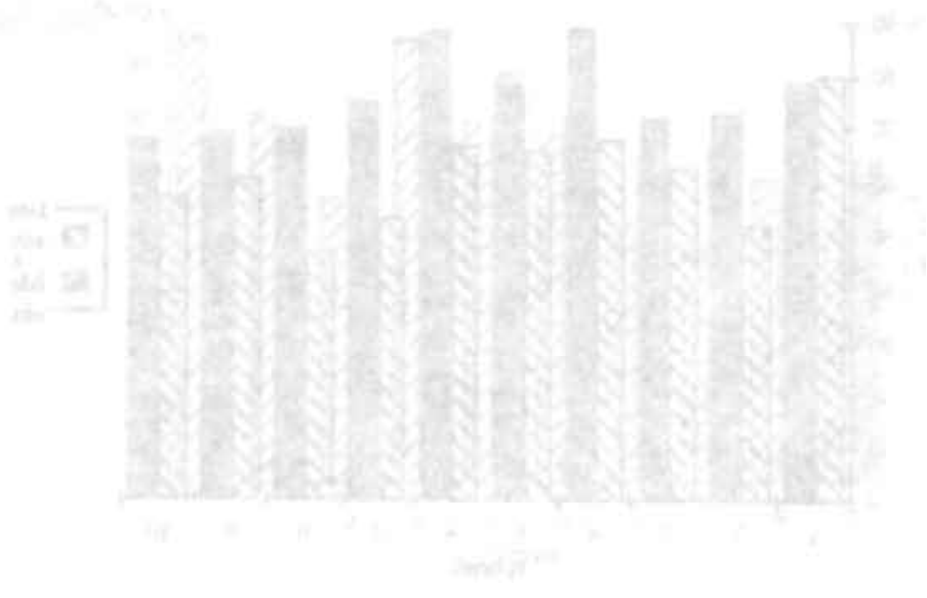




\section{Dankwoord}

Een onderneming als het voltooien van een proefschrift lukt alleen met steun en hulp van velen. Daarom is het goed dat er in elk proefschrift een plaatsje is ingeruimd is om de belangrijkste betrokkenen persoonlijk te danken.

Ik wil allereerst mijn eerste promotor professor dr.W.H.FW. Wijnen zeer veel dank brengen voor de onnavolgbaar geduldige en begrijpende wijze. waarop hij mij heeft begeleid in de afgelopen zeven jaar. Hij had bracht altijd begrip op voor de krachten die het afwerken van dit proefschrift in de weg stonden. Was het niet een klinische stage dan was er wel weer cen verblijf in het buitenland of een nieuwe baan. Wijnand, ik ben en blijf je zeer erkentelijk voor je hulp.

Pofessor dr. J.D.Mulder, destijds nog getooid met het mysterieuze achtervoegsel Dzn, was bereid om als tweede promotor op te treden, hoewel wij elkaar te voren niet kenden. Met zijn Leidse correctheid en zijn menselijke manier van omgaan heeft hij mij dikwijls op een heel prettige manier van advies gediend. Dank je Jan.

Dr. Lisa Tan stond aan de wieg van dit onderzoek. Zij nam mij aan als onderzoeker en probeerde mij zo goed en zo kwaad als dat ging te begeleiden. Ik heb zeer goede herinneringen aan onze vaak urenlange telefonische werkbesprekingen. Haar nauwgezetheid en streven naar perfectie inspireerden mij steeds om er net wat meer van te maken, dan ik oorspronkelijk van plan was. Lisa van harte bedankt.

De 'kleine begeleidingsgroep', bestaande uit Fried van Geldorp en Yvonne van Leeuwen gaf in het begin van het onderzoek veel, zeer relevant, commentaar. Zowel Fried als Yvonne ben ik dank verschuldigd voor hun loyale houding en de duidelijke 'drive' om van dit project iets te maken.

De werkgroep evaluatie van het $1 \mathrm{OH}$ fungeerde als klankbord. Zonder ieders steun was de toegang tot de acht instituten heel moeizaam verlopen. Zij maakten de weg vrij voor het onderzoek. Gerda van Zoen verrichtte de secretariele werkzaamheden in Amsterdam. Zij was de snelste en meest adequaat werkende secretaresse, die ik ooit ben tegen gekomen. Gerda, bedankt.

Voor de verwerking van de data verichtte Diana Riksen veel werk, onder het toeziend oog van dr. Cees van de Vleuten. Cees en Diana, hartelijk dank voor het beroep, dat ik steeds op jullie kon doen.

Prof. dr. H.FJ.M. Crebolder stimuleerde mij als hooldbegeleider in het SGO-programma Kadertraining Huisartsen om door te blijven gaan op de eenmaal ingeslagen weg.

Vele consulenten hebben hun medewerking verleend om het medisch-inhoudelijke deel praktisch maar toch verantwoord te maken. Van hen wil ik met name noemen dr. R.J. Michels, internist verbonden aan het AMC te Amsterdam en Prof. dr. A.C. Nieuwenhuyzen Kruseman, hoofd van de afdeling endocrinologie van de vakgroep Interne Geneeskunde van de RL. Mevrouw De Vries regelde een groot deel van de procedures, die een conceptproefschrift zoal te gaan heeft door de universitaire bureaucratie ook Fien van Deurse en Desiree Bronckers zijn mij behulpzaam geweest.

Daarnaast was de inbreng van drs. Olga Sollet van onschatbare waarde. Zij is verantwoordelijk voor de basis lay-out en produceerde een kleine twintigtal versies van dit proefschrift op haar Apple Macintush. 
Ik wil haar op deze plaats heel uitdrukkelijk bedanken voor al datgene, wat ze voor me heeft gedaan. Haar snelheid, overzicht en accuratesse zijn niet te evenaren.

Truus Smeets, secretaresse van de Stichting Diadata, droeg ook haar steentje bij in de afronding van dit onderzoek.

Last but not least dank ik mijn collega, Ben Ramaekers voor de prettige wijze, waarop hij mij de gelegenheid gaf om met het proefschrift bezig te zijn, terwijl het in de praktijk vaak erg druk was.

Tenslotte dank ik alle deelnemers aan het onderzoek voor hun bereidheid om mee te doen, meer speciaal de lichting '85-'86 van de huisartsen in opleiding in heel Nederland evenals de groep van 62 praktizerende huisartsen.

Lori Mees verzorgde de summary, thank you so much. 


\section{Curriculum vitae}

Jaap Zuidweg (1956) doorliep het Titus Brandsma Lyceum, afdeling Gymnasium B te Oss van 1968 - 1974. Hij studeerde geneeskunde aan de Rijksuniversiteit Limburg van 1974 tot 1980.

Daarna, in 1981, volgde hij de beroepsopleiding tot huisarts aan de Vakgroep Huisartsgeneeskunde. Opleider was R. Panhuysen te Voerendaal.

Hij was enkele jaren verbonden aan de vakgroep Sociale Psychiatrie van de RL (hoofd prof. dr. M.A.J. Romme), waar hij onder leiding van dr. Herro F Kraan onderzoek deed naar communicatie modellen in de arts-patient relatie. Van 1984 tot 1987 werkte hij bij het Huisartseninstituut van de U.v.A., (hoofd prof. dr. H. Lamberts) waar de basis werd gelegd voor dit proefschrift onder leiding van mevrouw dr. L.H.C. Tan.

Daarna was hij bij het Skillslab van de RL vaardigheidsdocent van 1988-1991. Als deelnemer aan de SGO kadertraining voor huisartsen (Hoofdbegeleider Prof. dr. H.FJ.M. Crebolder) deed hij ervaring op in de endocrinologie (AZM, hoofd prof. dr. A.C. Nieuwenhuyzen Kruseman), verdiepte hij zich op het terrein van de oogheelkunde op de polikliniek van het AZM (hoofd. prof. dr. F Hendrikse met als begeleider mevrouw M. Beintema, oogartsen) en verbreedde hij zijn psychotherapeutische vaardigheden in de ambulante geestelijke gezondheidszong bij de RLAGG Maastricht eo (E. Peeters, psychiater). Hij was in 19926 maanden als clinical fellow in family medicine aan Mc Gill University verbonden, werkzaam in the Herzl Clinic for family medicine, onderdeel van het Sir Mortimer B. General Jewish Hospital in Montreal, Canada (Head of department Dr. Cheryl Levitt BSc, M.B., B.C.H., C.C.F.P., mentor Dr. Michael Dworkind MDCM CCFP). De auteur is gevestigd als huisarts in Maastricht in associatie met H.Th.H. Ramaekers en interesseert zich in het bijzonder voor het begeleiden van patienten die lijden aan chronische aandoeningen, zoals diabetes mellitus, oogziekten en astma bronchiale. 
